
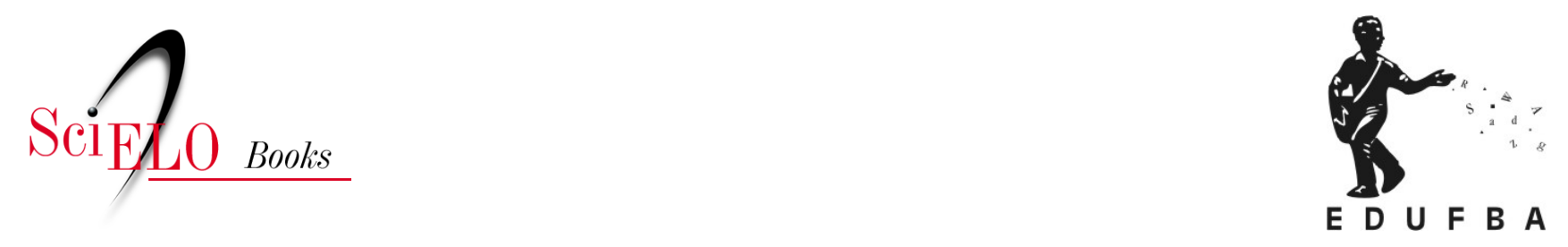

\title{
Jamais fomos zumbis contexto social e craqueiros na cidade de São Paulo
}

\author{
Ygor Diego Delgado Alves
}

\section{SciELO Books / SciELO Livros / SciELO Libros}

ALVES, Y.D.D. Jamais fomos zumbis: contexto social e craqueiros na cidade de São Paulo [online]. Salvador: Edufba: Cetad, 2017, 350 p. Drogas: clínica e cultura collection. ISBN: 978-85-232-1859-1. https://doi.org/10.7476/9788523218591.

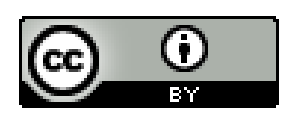

All the contents of this work, except where otherwise noted, is licensed under a Creative Commons Attribution $\underline{4.0 \text { International license. }}$

Todo o conteúdo deste trabalho, exceto quando houver ressalva, é publicado sob a licença Creative Commons Atribição 4.0. 


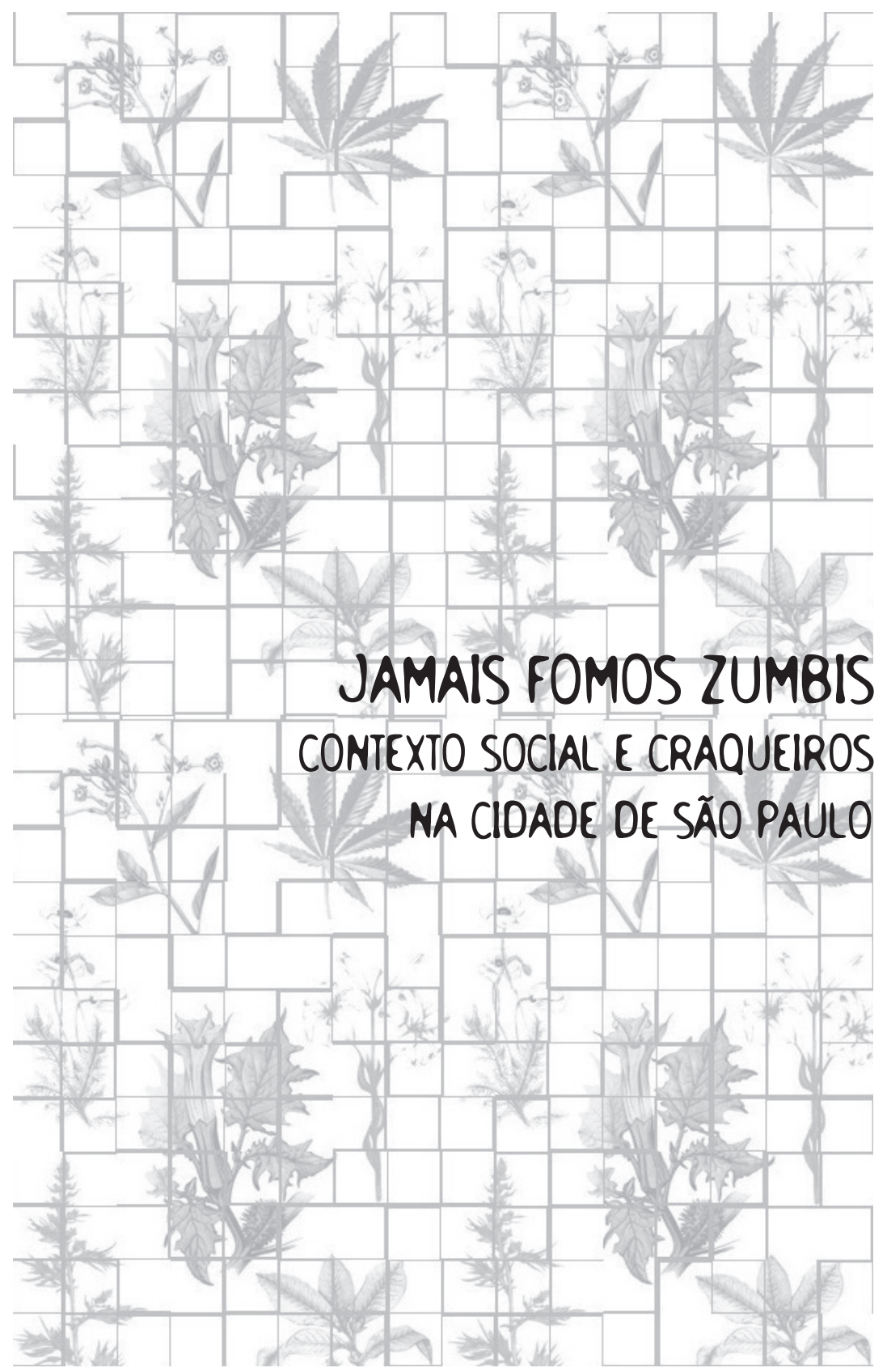


UNIVERSIDADE FEDERAL DA BAHIA

Reitor

João Carlos Salles Pires da Silva

Vice-reitor

Paulo Cesar Miguez de Oliveira

Assessor do reitor

Paulo Costa Lima

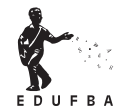

EDITORA DA UNIVERSIDADE FEDERAL DA BAHIA

Diretora

Flávia Goulart Mota Garcia Rosa

CONSELHO EDITORIAL

Alberto Brum Novaes

Angelo Szaniecki Perret Serpa

Caiuby Alves da Costa

Charbel Ninõ El-Hani

Cleise Furtado Mendes

Evelina de Carvalho Sá Hoisel

José Teixeira Cavalcante Filho

Maria do Carmo Soares de Freitas

Maria Vidal de Negreiros Camargo

CONSELHO EDITORIAL DO CETAD/UFBA

Luiz Alberto Tavares (Coordenador)

Ana Rita Cordeiro de Andrade

Antônio Nery Filho

Edward MacRae

George Hamilton Gusmão

Maria Eugenia Nunes

Marlize Rêgo 
Ygor Diego Delgado Alves

\section{JAMAIS FOMOS ZUMBIS CONTEXTO SOCIAL E CRAQUEIROS NA CIDADE OE SÃO PAULO}

Salvador, 2017

EDUFBA

Drogas: Clínica e Cultura CETAD/UFBA 
2017, Ygor Diego Delgado Alves.

Direitos para essa edição, cedidos à EDUFBA e ao CETAD/UFBA.

Feito o depósito legal.

Grafia atualizada conforme o Acordo Ortográfico da Língua Portuguesa de 1990, em vigor no Brasil desde 2009.

Projeto Gráfico da Coleção e Capa

Yure Aziz e Karime Salomão

Editoração Eletrônica e Arte final da Capa

Rodrigo Oyarzábal Schlabitz

Revisão e normalização

Larissa Caroline D. Borges/Carina dos Santos

Sistema de Bibliotecas - UFBA

A474 Alves, Ygor Diego Delgado.

Jamais fomos zumbis: contexto social e craqueiros na cidade de São Paulo /

Ygor Diego Delgado Alves. - Salvador: Edufba: Cetad, 2017.

350 p. il. (Coleção drogas: clínica e cultura).

ISBN 978-85-232-1587-3

1. Drogas ilícitas. 2. Crack (drogas). 3. Saúde. 4. Jovens - Uso de drogas. I. Titulo. II. Título.

\section{Ex

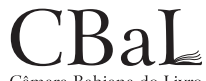

Câmara Bahiana do Livro

Centro de Estudos e Terapia do Abuso de Drogas - CETAD/UFBA

Extensão Permanente da Faculdade de Medicina da UFBA

Rua Pedro Lessa, 123 - Canela, CEP: 40110-050 - Salvador-BA

Tel: (71) 3283-7180 Fax: (71) 3336-0466

www.cetadobserva.ufba.br

Editora da Universidade Federal da Bahia - EOUFBA/UFBA

Rua Barão de Jeremoabo s/n, Campus de Ondina, 40170-115 - Salvador-BA

Tel/fax: (71) 3283-6164, www.edufba.ufba.br. E-mail: edufba@ufba.br 
Para Andréia e Isabela. 


\section{AGRADECIMENTOS}

Agradecer a todos que contribuíram para a elaboração de um livro é reconhecer publicamente sua importância. Declarar que sem eles, o trabalho não poderia ter sido feito da maneira como ocorreu. É também os eximir de qualquer responsabilidade nas imprecisões e mesmo erros, que certamente cometemos no processo de pesquisa e também na escrita. Se possivel fosse, este seria também o momento de retribuir tudo que me foi dado pelas dezenas de pessoas que foram envolvidas por mim, neste trabalho. Porém, seria muita pretensão de nossa parte crer que estes singelos parágrafos de agradecimento fossem capazes de retribuir tudo o que por esta obra foi feito graças a terceiros. Mesmo porque, muitos não tiveram seu nome e nem mesmo seu vulgo mencionado no decorrer do texto. Eles também não serão mencionados, dado o caráter ilegal das práticas que pesquiso, desde minha graduação em Ciências Sociais. O proibicionismo nos retira muitas coisas, inclusive vidas, a supressão da possibilidade de agradecer mais claramente certos envolvidos aqui, é apenas mais uma de suas funestas consequências.

Deslocamo-nos da cidade de São Paulo para Salvador, com o propósito claro de sermos orientados por Edward MacRae. Acreditamos, sem muito risco de exagero, que não há outro acadêmico no Brasil que pudesse orientar este trabalho na radicalidade com que foi elaborado. Uma pesquisa que parte da convivência respeitosa com usuários de crack, sujeita a todos os riscos impostos pelo proibicionismo, requer não apenas confiança por parte de orientador e orientando em sua base teórica e metodológica, mas também certa dose de sangue frio. A pesquisa não foi feita sem alguns sustos. Portanto, foi fundamental a serenidade do orientador advinda de larga experiência no campo acadêmico e político relacionado às drogas.

A obra de Edward MacRae dedicada à pesquisa antropológica no campo das drogas é marcada por um profundo cuidado 
teórico e metodológico. Sua dedicação e cuidado com o trabalho do orientando garantem que este arcabouço esteja presente na pesquisa e análise dos dados. Foi certamente um grande esforço de orientação, coroado pelo prefácio deste livro, que aqui reconhecemos e agradecemos.

Além do trabalho minucioso do orientador, outros sujeitos se envolveram na elaboração do texto. Aqui destaco a pessoa de Adriano de Camargo, grande conhecedor do usuário de crack, particularmente, do frequentador da Cracolândia paulistana. Seu conhecimento foi fundamental para que pudéssemos ter um olhar mais preciso sobre seu cotidiano. Isto se deu num vigoroso processo de acompanhamento de suas oficinas de futebol, frequência às reuniões da Associação Brasileira Multidisciplinar de Estudos sobre Drogas (ABRAMD), participação em congressos e até a organização de um simpósio. Tornamo-nos coautores de um livro sobre metodologia do trabalho de futebol com população de rua, a Pedagogia do comprometimento. Aproveito para agradecer também a sua esposa Tuca por todo apoio nesta pesquisa.

Não poderia deixar de lembrar a querida Telva, que nos idos do início dos anos 1990, do século passado, me dirigiu pelos primeiros passos no "mundo das drogas".

A imersão profunda que fizemos no campo, nossa etnografia dos usuários de crack da região central da cidade de São Paulo, jamais seria possivel sem a contribuição de Newman. Ele foi a nós apresentado graças ao interesse de Roberto Ruiz e a colaboração de Ronnie Pizzi. Newman foi de uma imensa generosidade. Levou-nos ao campo, onde fomos apresentados aos seus amigos de muitos anos. Pudemos com eles conviver por certo tempo, mesmo após Newman decidir abandonar o uso do crack. Isto, graças ao prestígio gozado por ele no meio dos usuários. Sua vida mudou imensamente nestes últimos meses e lhe desejamos toda sorte. 
Agradecemos a Coordenação de Aperfeiçoamento de Pessoal de Nivel Superior (Capes) pela bolsa de doutorado sem a qual não poderíamos ter desenvolvido esta pesquisa. Ao professor Edmilson Felipe da Pontificia Universidade Católica (PUC/ SP) pelas indicações bibliográficas. Ao prof. dr. Stelio Marras do Instituto de Estudos Brasileiros da Universidade de São Paulo (IEB/USP). A todos(as) professores(as) do Programa de Pós-Graduação em Antropologia da Universidade Federal da Bahia (PPGA/UFBA) de quem tivemos a honra de sermos alunos: prof. dr. Carlos Alberto Caroso Soares, profa. dra. Cecilia Anne McCallum e a profa. dra. Francesca Bassi Arcand, além, é claro, do valoroso curso ministrado pelo nosso orientador. Aos coordenadores(as) que levaram o programa à diante: profa. dra. Cíntia Beatriz Müller, prof. pr. Diego Ferreira Marques e a profa. dra. Fátima Regina Gomes Tavares. À funcionária do PPGA, Livia Cavalcanti e a todos(as) os trabalhadores(as) do campus de São Lázaro, meus sinceros agradecimentos.

Aos membros da banca: prof. dr. Pedro Paulo Gomes Pereira, profa. dra. Urpi Montoya Uriarte, profa. dra. Elena Calvo Gonzalez e Osvaldo Francisco Ribas Lobos Fernandez. Grato e honrado por aceitarem nosso convite.

À equipe da Editora da Universidade Federal da Bahia (Edufba) meus maiores agradecimentos pelo trabalho dedicado e competente.

Um agradecimento especial ao prof. dr. Pedro Paulo Gomes Pereira pela generosidade em fazer a introdução que tanto abrilhanta este livro.

Aos nossos amigos baianos: Thais Bonini, Toni Couto, Rejane Andrade, Catia Ladeia (Fia), Rosa Couto, Luisa Bonini, Silvia Bonini e Bianca Valente. Sem o acolhimento de vocês, nossa estadia em Salvador não teria sido tão prazerosa. Obrigado Iara Bonini, por compartilhar seus brinquedos com minha filha. Os colegas da Escola de São Lázaro: Dudu Ribeiro, 
Luana Malheiro, Vinicius Alves e Joey foram as companhias mais proficuas da cidade.

À minha familia que sempre precisou lidar com minhas escolhas um tanto constrangedoras de objeto de estudo. Obrigado, mais uma vez, pela compreensão: Carmen, Gastón, Eduardo, Ieda, Graciela, Marcelo e Camila. À minha mãe que tão ansiosamente desejava ver o filho doutor e, infelizmente, não conseguimos a tempo dar-lhe esta última alegria e a meu pai que tanto dedicou-se aos estudos do filho, meus agradecimentos.

À amada esposa Andreia Cocka, que dá o compasso de nossas vidas e nossa adorada filha Isabela, obrigado pela imensa compreensão dada a trabalho tão sui generis. Ambas acabaram atingidas pela pesquisa sem jamais reclamar. Não poderíamos ter tido mais sorte.

Foram dezenas de usuários de crack com quem tivemos o prazer de conviver nestes anos de pesquisa de campo. A todos eles minha mais profunda solidariedade. Não há objetivo maior, nesta obra, que reconhecer-lhes a dignidade, o valor, o discernimento e a vontade. Não irei expor o nome de nenhum deles aqui, como não fiz no restante do livro.

Para o usuário que alta madrugada encontra-se saindo da "biqueira", com um saco nas costas a fim de fazer seu "corre" honesto como catador de latas. Todo nosso esforço é pouco. Você merecia muito mais deste antropólogo. 


\section{SUMÁRIO}

Prefácio

Apresentação

Introdução

0 uso do crack como ele é: pesquisa observação participante entre usuários de crack

Acessando d "biqueira"

Participando de roda de crack em uma "biqueira" 54

frequentando uma "biqueira" com fumódromo a céu aberto 57

Quem é mais ladrão?

Os interlocutores Cláudia e Salomão no morrinho

0 uso do gravador e câmera fotográfica levanta a questão da segurança do pesquisador e interlocutores

Prejuizos à saúde e convivência familiar 84

A roda de crack: cachimbo, bloco e usuário na rede social

Maquinários e o cachimbo 88

0 "boris" e a redução de danos 104

0 "bloco" e o "trago" 106

A roda de crack

A roda de crack, a TAR e o cachimbo como "coisa"

Dois contextos para rodas de crack: o fumódromo e a Cracolàndia 
Os modelos andíticos, sud adequação do uso do crack e d "communitas" dos usuários

0 modelo de Howard Becker e 0 uso do crack ........................... 138

Além da dependência física e psicológica, a dependência social ...... 167

Norman E. Zinberg e a importància do setting no uso de drogas ... 176

Setting. padrão de uso e rituais para Zinberg e o consumo de crack

A "communitas" em torno do uso do crack 209

Período e frequência de uso: o zumbi desmascarado

Jamais fomos zumbis: duas experiências de mudança no contexto social do usuário de crack

0 Programa De Braços Abertos: ruptura, continuidade e radicalização da redução de danos

A frente de Trabalho e o Trio 234

A tenda e o fluxo 237

0 Programa DBA: integração do invés de gentrificação 243

Lucas, o prefeito e um programa voltado ao trabalho 250

O Programa De Braços Abertos como oportunidade de mudança na estrutura de vida 
"0 jogo tá pegado": times e campeonatos de futebol com jogadores usuários de crack na região central da cidade de São Paulo ..... 275

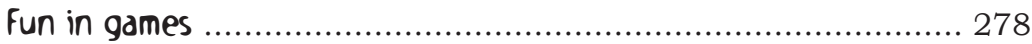

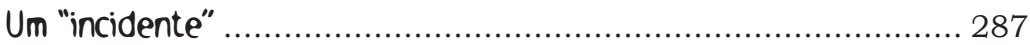

A manipulação das regras do jogo ......................................... 301

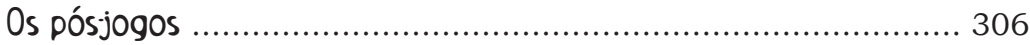

Autocontrole, o uso de crack e oficinas de futebol ..................... 311

De brigas de galos e incidentes entre homens ........................ 322

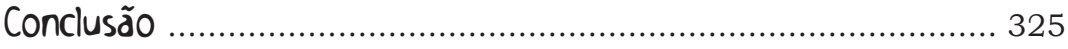

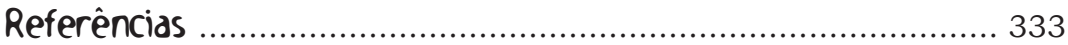

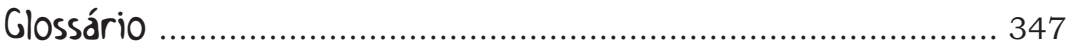




\section{PREFÁCIO}

Foi com grande prazer e sentimento de honra que recebi o convite para prefaciar este livro do meu amigo e antigo orientando, Ygor Delgado Alves. Nosso encontro original deu-se já há muito tempo, quando ele gentilmente me deu acesso à sua dissertação de mestrado sobre o uso tradicional e medicinal da maconha que havia detectado no interior potiguar. Achei muito interessante o trabalho, mas depois passamos um longo tempo sem nos contatar até ele se apresentar como candidato a uma vaga no doutorado em antropologia na Universidade Federal da Bahia (UFBA), com um projeto sobre usuários de crack. Após eu ter sido designado como seu orientador, passamos a conversar sobre as possíveis abordagens do tema. Ele logo deixou claro seu desejo de se afastar do ponto de vista dos serviços que atendem essa população, tradicional nesse tipo de pesquisa, por ser uma forma mais fácil e segura de ter acesso a essa população. Ygor pretendia enfocar em outro tipo de consumidor, além da usual clientela desses serviços, quase inevitavelmente composto dos casos mais patológicos e disfuncionais, estudados geralmente de maneira descontextualizada da "cultura de uso". Ele considerava importante levar em conta outros tipos de usos e usuários, para evitar que os resultados fossem enviesados. Também defendia a necessidade de se ter um conhecimento da sua sociabilidade e do funcionamento dos diversos agentes envolvidos, inclusive os não humanos. Desde o início, ele tinha plena consciência de que os resultados do uso de substâncias psicoativas dependeriam de uma variada série de fatores e, devido ao seu treino como cientista social, ele se via mais preparado para abordar os aspectos socioculturais da questão, sem deixar de dar importância a fatores mais subjetivos ou fisiológicos. 
Pensamos em dirigir o estudo a outros grupos, como o de usuários de classe média, por exemplo. Lá, talvez fosse possivel observar diferenças relevantes nas práticas e consequências envolvendo o uso de crack em meios socialmente integrados, onde ele talvez se revestisse de outras conotações sociais e simbólicas, diferentes das correntes entre moradores de rua e demais grupos socialmente excluídos. Para fugir do viés institucional, Ygor pensou em começar a partir de sua própria rede de amizades ou contatos, o que o levou a desenterrar uma série de antigas vivências de quando ele mesmo havia tido problemas devidos uma relação danosa com psicoativos. Sua opção foi a de assumir em campo a identidade de ex-usuário problemático de drogas, que não deixava de ser verdadeira, embora há muito houvesse superado aquela condição. Confesso ter ficado preocupado, pensando como ele estaria se expondo a novos riscos que poderiam levar a uma retomada de suas antigas relações descontroladas e prejudiciais com substâncias psicoativas. Porém, a qualidade de sua adesão ao curso de pós-graduação e à disciplina mental e acadêmica exigida, logo me aliviaram e pude acompanhar mais tranquilamente as suas vivências na Cracolândia, localizada no centro da cidade de São Paulo. Não deixei, porém, de apreciar a sua coragem ao se apresentar como usuário de psicoativos ilícitos ao público acadêmico ou leitor. Seguia o caminho recentemente trilhado por outro pesquisador sério e destemido, Maurício Fiore, que também não hesitou em relatar na sua tese seus usos de drogas ilícitas, incluindo o crack. (FIORE, 2013) Senti uma benfazeja mudança de clima e acreditava perceber as primeiras rachaduras no muro de silêncio que se construiu em torno da questão das drogas.

Acredito que a ousadia de Ygor, nesse sentido, sirva para desmistificar a aura demoníaca e irresistivel que tende a ser atribuída ao crack, permitindo que ela também seja pensada a partir de paradigmas mais complexos e que não se resumam aos seus efeitos farmacológicos, supostamente geradores de uma irresistivel dependência entre seus usuários. O autor nos fornece 
também um bem argumentado exemplo de como o antropólogo, realizando pesquisa sobre usuários de psicoativos, pode torná-la mais completa e profunda ao adotar técnicas de observação participante que não deixem de incluir o próprio compartilhamento das substâncias usadas pelos seus interlocutores.

Nas cenas de uso do centro da capital paulista, frequentemente vista com temor exagerado por alguns outros pesquisadores, Ygor conseguiu realizar uma boa entrada em campo, graças à um interlocutor inicial seu, de classe média, que o apresentou às pessoas certas da Cracolândia. Assim, mesmo voltando a um estudo do uso do crack entre pessoas provenientes principalmente das camadas mais desprivilegiadas, sua abordagem seria diferente das usuais, já que adotaria o ponto de vista do usuário e não o do técnico de serviços públicos ou privados. Assim, sua estratégia de pesquisa incluiu o uso ocasional de crack e ele não se furtou de frequentar lugares de venda e consumo da droga para embasar seu estudo. Pôde, assim, trazer uma rica descrição do funcionamento das "biqueiras" do centro de São Paulo, da produção dos cachimbos, de outros artefatos mediadores do consumo da droga e de projetos sociais como o Programa De Braços Abertos (DBA), coordenado pela Prefeitura de São Paulo, e os treinos e campeonatos de futebol realizados entre os frequentadores da Cracolândia.

O resultado foi uma observação participante raramente encontrada neste tipo de pesquisa, devido à toda sorte de dificuldades que apresenta, inclusive a do pesquisador ser visto como traficante pelas autoridades policiais. Desvendou-se então uma cena muito mais diversa do que a normalmente apresentada e os frequentadores e usuários de crack da Cracolândia paulistana puderam ser vistos de uma forma mais nuançada, onde sua humanidade não era completamente subsumida pelas suas práticas de uso. Esse caminho já havia começado a ser percorrido por minha amiga e atual orientanda, Luana Malheiro, em sua brilhante pesquisa de conclusão de curso de graduação, sobre o uso de crack no Centro Histórico de Salvador e que 
Ygor cita bastante em seu trabalho. (MALHEIRO, 2013) A partir de um enfoque que privilegiava categorias nativas encontradas em campo, ela também foi capaz de trazer uma série de novas e frutiferas ideias para a discussão. Agora, com sua pesquisa de doutorado, Ygor pode levar mais adiante as questões levantadas por ela, mas mantém a ênfase de Luana na maneira como os componentes do mundo das drogas são múltiplos e fazem diferentes sentidos para os usuários e demais frequentadores da região. A partir desses dois autores, podemos perceber como a vida do usuário de crack não se resume a uma busca única e obsessiva, impelida inexoravelmente pela "fissura" da droga.

Em seu estudo, Ygor desmistifica alguns dos supostos perigos do trabalho de campo junto a essa população, que se mostrou a ele menos perigosa e ameaçadora do que costuma ser apresentado em muitos estudos. Ele pode até falar do prazer de estar na companhia desse público, enquanto outros, com menos familiaridade com essa população, enfatizam a mais a sua suposta abjeção, talvez refletindo o seu próprio estranhamento perante maneiras de viver tão diversas das suas. Esse olhar, francamente positivo, seria aplicável a qualquer agrupamento humano, onde a tristeza e a felicidade se manifestam de maneiras imprevisiveis, mas raramente o havia visto dirigido à população de usuários de crack. Acredito que esta tenha sido uma das principais contribuições do Ygor ao estudo e ao atendimento desses sujeitos.

Ao mudar o enfoque costumeiro, a narrativa produzida por Ygor sobre usuários e usos de crack em áreas centrais de São Paulo, busca entender as origens da fortíssima estigmatização sofrida por eles e as razões do medo que inspiram no público em geral, apesar de comporem um dos setores mais fracos e perseguidos da população. Afinal, são eles, os que são constantemente sujeitos a inúmeras ameaças à sua integridade fisica e moral, chegando frequentemente a enfrentar perigo de morte. Para tanto, trata do fenômeno no contexto do pânico 
moral, gerado em torno do usuário e propagado por "empresários morais", como diz Becker. Estes incluem os integrantes do que o saudoso Richard Bucher chamava de "máfia antidrogas", aqueles que lucram com as politicas proibicionistas e repressivas. (BUCHER,1996, p. 59) O chamado "pânico moral" é geralmente promovido por meios de comunicação e outros importantes formadores de opinião que costumam transmitir visões exageradas e simplificadas de determinadas práticas de grupos sociais já sujeitos a discriminação de vários tipos. Fortes campanhas midiáticas vêm difundindo nos últimos anos sentimentos de medo e rejeição em relação aos usuários de crack, criando um clima emocional que atualmente permite e até fomenta, a implementação de políticas públicas de repressão e encarceramento. No bojo destas, criou-se um mercado voltado ao sequestro e aprisionamento em clínicas de tratamento para usuários provenientes da classe média. Para os mais pobres, criaram-se locais de confinamento em instituições filantrópicas e precárias, geralmente de orientação religiosa, desprovidas de base científica para suas técnicas e onde a ordem é, muitas vezes, mantida de maneira extremamente autoritária e violenta. São verdadeiros depósitos humanos, pouco diferindo dos antigos manicômios. Apesar de seus aspectos retrógrados e claramente higienistas, políticos conservadores e órgãos públicos sob sua influência têm reservado importantes verbas para essas autodesignadas "comunidades terapêuticas", desviando recursos que por lei deveriam ser reservadas para instituições laicas, mais inclusivas e de eficácia comprovada.

Em sua descrição do campo, Ygor nos apresenta um cuidadoso retrato da cultura de uso, com sua terminologia específica, de seu cotidiano e dos diferentes papéis sociais desempenhados em seu seio, assim como dos sentimentos pessoais dos sujeitos envolvidos. Estes dados são analisados a partir das obras pioneiras de Howard Becker, Norman Zinberg e Jean-Paul Grund sobre os controles sociais formais e in- 
formais que incidem sobre o uso de drogas, permitindo uma melhor compreensão da importância do contexto social sobre o padrão intenso de uso encontrado. A análise do Programa DBA e dos times de futebol, constituídos em sua maioria, por usuários, mostra, por exemplo, como a alteração do contexto social é capaz de produzir grandes mudanças no relacionamento do usuário com a substância.

Como o introdutor no Brasil de parte dessas referências para o entendimento das maneiras como a questão das drogas se coloca entre nós, fico especialmente satisfeito com as opções teóricas e metodológicas adotadas neste livro e pelo aporte importante que traz à rediscussão do valor dessas concepções. No presente livro, Ygor desmistifica a suposta dificuldade de conciliar a abordagem de Becker e seus seguidores com as visões de Bruno Latour, muito em voga atualmente. Estabelece um profícuo diálogo com elas ao mesmo tempo em que também mapeia práticas e identidades encontradas entre usuários e traz importantes aportes para os debates sobre as politicas públicas voltadas a essa população. Nesse sentido, Ygor chama atenção para a amizade pessoal existente entre os dois pesquisadores, que alguns críticos gostariam de conceber como opositores radicais, e ressalta também suas afinidades intelectuais.

A abordagem de Ygor não pretende apenas versar sobre todos os fenômenos do uso de substâncias psicoativas de uma explicação cultural exclusivista, reconhece-se a sua natureza multifacetada, em que fatores de toda ordem interagem constantemente e de maneira intensa. Opta-se, porém, pelos métodos já desenvolvidos pelas disciplinas das ciências sociais e adequadas à uma compreensão que seja útil para o desenvolvimento de ideias que politizam a questão e eventualmente possam vir a subsidiar políticas públicas mais condizentes com a realidade. Entende-se que as políticas públicas não contemplam inteiramente a questão, que requerem uma abordagem multidisciplinar e não pode prescindir do conhecimento das 
ciências biológicas ou psicológicas, em todas as suas vertentes. Assim, sem a pretensão de produzir uma concepção exclusiva e final do seu tema, Ygor opta por se manter dentro dos limites de sua disciplina e metodologia. Dessa forma, além de se orientar por concepções e categorias latourianas, ele não hesita em adotar também outras categorias, bastante referenciadas e correntes na literatura antropológica, como "cultura do uso de drogas", "identidade", "ritual”, "communitas", "carreira desviante", "estilo de vida", "subcultura da droga”, que lhe são uteis em discutir aspectos das práticas politicas ou assistenciais voltadas para essa população.

O estudo é bom e há os que pedem ainda mais. Gostariam, por exemplo, de ver mais aprofundadas as discussões sobre temas como a relação dos frequentadores da Cracolândia com o tráfico de drogas, com as grandes organizações criminais como o Primeiro Comando da Capital (PCC) e com outros membros da população de rua. A estes, devemos lembrar as restrições temporais e financeiras de uma pesquisa de doutorado, como esta foi em sua origem. Acredito que Ygor cumpriu muito bem o objetivo principal a que se propôs, que era examinar as dinâmicas da Cracolândia e as práticas que se desenvolvem aí em torno do consumo de substâncias psicoativas. A importância desse objetivo é dada pela situação ainda reinante onde se encontra muito mais fantasia do que conhecimento consistente sobre o tema. Talvez a maior contribuição deste trabalho seja justamente a sua desmistificação desse universo e a sua humanização dos personagens envolvidos, mostrados aqui de maneira mais tridimensional do que o costume. Sem dúvida, o autor foi muito feliz em produzir o que considero como a mais completa, corajosa e iluminadora etnografia já produzida sobre uma Cracolândia brasileira.

Edward McRae 


\section{APRESENTAÇÃO}

\section{Corpos intensivos, crack e etnografia}

Quem anda pela região central de São Paulo pode se deparar com uma paisagem caracterizada por centenas de usuários de crack, esparramados entre ruas e edificios antigos, entre barracas de plásticos pretos e guarda-sóis, compondo um espaço denominado de Cracolândia. A quantidade de pessoas e a acentuada movimentação pelo centro e pelas imediações surpreendem os olhares dos que por lá circulam e têm chamado atenção dos órgãos do governo, de Organizações Não Governamentais (ONGs), de instituições religiosas e da mídia. Os corpos geralmente magros, sujos, intensivos desafiam as politicas públicas e interpelam a população com sua presença no meio de uma das maiores cidades do mundo.

A propósito desse agrupamento, toda uma sorte de conjecturas e de especulações metafisicas foi formulada: Por que tamanha quantidade de corpos inconformes em região tão central na cidade? Como acabar com o tráfico e comércio de drogas tornadas ilícitas? Surgem, inclusive, especulações nada humanistas, como: de que maneira "limpar" uma área que deveria ser "nobre"? Como extirpar essa "parte indesejável" da população? Assim, essas conjecturas e especulações revelam também uma faceta da sensibilidade contemporânea. Nesse âmbito, não é incomum práticas violentas na lida cotidiana com esses corpos indesejáveis.

Diante dessas e de outras perguntas, experts são chamados a formular politicas e a dar explicações. E os discursos circulam: de certo tipo de profissional de saúde bem-intencionado, que sabe antecipadamente o que esses corpos precários precisam e que não hesita em repassar suas "práticas de prevenção" com superioridade; de professorxs a discorrerem sobre "riscos" e a alertarem sobre os perigos do consumo de drogas; de par- 
te da mídia que demoniza os "craqueiros", exultando inclusive práticas repressivas; e por aí vai. Mas, evidentemente, aparecem nesse turbilhão de agentes interessados nos usuários de crack, politicas mais ou menos efetivas e sujeitos mais ou menos envolvidos e afetados por essa realidade.

É sobre esse contexto complexo que Ygor Diego Delgado Alves se volta em Jamais fomos zumbis, agora lançado pela Editora da Universidade Federal da Bahia (EDUFBA). Ygor fez seu trabalho de campo numa "biqueira" com fumódromo (em dois locais, um fechado e outro aberto) e na Cracolândia. O autor foi se achegando aos usuários de crack, e neles, descobriu muito mais do que a imagem comum, veiculada na grande mídia e mesmo por pesquisadores, de mortos vivos, de pessoas sem vontade e exclusivamente imersas no consumo de crack.

$\mathrm{O}$ autor deste livro enfrentou os desafios de uma pesquisa etnográfica nessa paisagem, abordando os dilemas do investigador diretamente envolvido e implicado nesse contexto. Seu movimento foi o de se aproximar dos usuários de crack sem se apresentar como "redutor de danos", sempre evitando se colocar como aquele que já sabe de partida os males dos corpos e almas com os quais conviveu na pesquisa etnográfica. Num de seus capítulos mais densos, por exemplo, o autor descreve os materiais usados para o consumo de crack, com atenção para o cachimbo. Ele narra com detalhes as técnicas de consumo de crack, as maneiras de se alcançar um "bom trago"; disserta sobre a roda de crack e sobre o fumódromo; delineando sua hierarquia e seus personagens principais; entra no "circuito da treta" e mostra como essa "parafernália" que tem no cachimbo seu mais complexo e instigante componente. Ygor vai revelando como o cachimbo é um mediador afeito das intervenções dos usuários e fruto de sua criatividade nas ações contínuas de reconstruí-lo na deriva do uso da pedra. Corpo e cachimbo são reconstruídos nesse processo. Como se aquela visão do zumbi fosse contrastada por outra, a de homens e mulheres que não 
vivem subsumidos exclusivamente num mundo de alienação e fora de si: as manufaturas no cachimbo revelam a capacidade de criação e de expressão desses corpos e almas.

A rua torna-se espaço de relações das pessoas que usam crack. O fluxo de pessoas e sua junção em espaço concentrado é uma das estratégias de enfrentar as duras noites do centro de São Paulo. A associação é fundamental, e estar com outros usuários de crack, outros "parças", condição mesma de estar na rua.

Além disso, o autor deste livro, imerso no dia a dia dos usuários de crack, pôde perceber suas variações corporais entre vigília e sono, e compreendeu como estes estados se misturam. O estado de sono ou a mescla de sono e vigília são partes da totalidade do ciclo de uso. O "estigma" do zumbi toma, portanto, a parte pelo todo e não dá conta da complexidade das diversas formas de relação com a droga. No decorrer do livro, o autor não deixa nunca de se posicionar, de indicar como "falácias" argumentações que se afastam do que ele encontrava em campo. Um exemplo de engano (enormemente propalado) que ele localizou e a ele se contrapôs foi a ideia de que a experimentação do crack levaria à imediata compulsão e de que esta forma de uso seria a única possivel.

Comos se nota, Ygor faz referência a um livro de Bruno Latour logo no título, evocando: “Nous n'avons jamais été modernes" (Jamais fomos modernos), e coloca na boca dos usuários: "Jamais fomos zumbis". Esse diálogo com Latour está por todo o livro, e na busca de seguir o movimento teórico latouriano, descreve humanos e não-humanos, assinalando o cachimbo como um "mediador" e se vale de termos como "artefatos", "não-humanos", "mediadores" e "teoria ator rede". Se seu vocabulário teórico parte de Latour, também aparecem em sua narrativa expressões como: "nativo", "êmico", etc., e de conceitos como "estigma" e "communitas". A intenção é fazer dialogar teorias. 
Todavia, como pensar com Latour abordando justamente esses corpos à deriva no centro urbano? Latour fora incisivo em defender uma antropologia do centro, sustentando que quando fazíamos antropologia dos "outros", buscávamos os seus aspectos principais e centrais, mas quando realizávamos uma antropologia de nós mesmos, geralmente nos dedicávamos aos aspectos marginais de nossa sociedade. Ygor mostra, então, que os corpos precários dos usuários de crack mobilizam aparatos significativos do Estado, movimentavam cientistas de todo tipo, profissionais de saúde e instituições religiosas. De forma que, pesquisar na Cracolândia era se imiscuir na própria "matéria vertente": ciência, Estado e religião, e agir sobre as vidas que impõe sua presença no cenário urbano da intricada cidade de São Paulo.

No final do livro, o leitor poderá perceber que o "vai e vem" de vocabulário e de conceitos, as interações entre teorias, são importantes, mas que a maior contribuição de Ygor - o autor deste livro - provavelmente está na forma com que ele se aproxima de seus interlocutores e que se coloca no campo, na maneira como é muitas vezes levadoe afetado por esses corpos intensivos. É justamente por esse movimento e pelo envolvimento com seus interlocutores que consegue enxergar, sem ser condescendente e sem deixar de assinalar a gravidade da situação, potência onde outrxs só viam "riscos", "deficiências", "pânico". Esse movimento que o permitiu ver criatividade nos espaços onde muitxs só perceberam zumbis.

Pedro Paulo Gomes Pereira

Nova Iorque, novembro de 2015. 


\section{INTRODUÇÃO}

Este livro trata do uso do crack na região central da cidade de São Paulo, onde se encontram diversos locais de comércio, de uso e mistos. Estes últimos se dedicam, além da venda, também a oferecer local para o consumo desta substância psicoativa tornada ilícita. Lá está a Cracolândia paulistana, um espaço símbolo do pânico moral em torno do "craqueiro" e local de intervenções cruéis e desastrosas por parte do poder público, particularmente os entes municipal e estadual nas gestões José Serra e Gilberto Kassab frente à prefeitura municipal, e José Serra e Geraldo Alckmin frente ao governo estadual de São Paulo. Estas administrações chegaram ao ponto de implementar uma ação repressiva denominada "dor e sofrimento" que resultou em humilhante fiasco. Mas, a região também é palco de uma das mais ousadas e exitosas politicas de intervenção pública sobre uma população usuária de drogas no Brasil; que parte da garantia de acesso aos direitos fundamentais como moradia, saúde, trabalho e estudo através do Programa De Braços Abertos (DBA), que atualmente se expande para outras áreas da cidade.

Embora, o crack e o seu usuário tenham sido objetos de uma grande exploração midiática, a ponto de o usuário ser igualado a um "morto-vivo" ou a um zumbi, muito pouco se sabe a respeito do uso dessa droga, além de uma série de preconceitos repetidos à exaustão, como por exemplo, a ideia de que a experimentação leva imediatamente à compulsão e de que esta forma de uso é a única possivel. Portanto, ao escolhermos o uso do crack como objeto de nosso estudo, nós estamos procurando cobrir uma lacuna imensa no conhecimento a respeito do uso de drogas. Mormente, se levarmos em conta que o uso do crack, pelas possibilidades abertas à exploração midiática por seu consumo nas ruas, foi alçado a um dos principais 
problemas de saúde e segurança pública do país, nesta virada de milênio.

O crack fumado na região central da cidade de São Paulo, área de nossa pesquisa, é produzido a partir de pasta base, geralmente proveniente do interior do estado. Esta pasta base, após processo de feitio, com sua diluição em água quente e reação química por adição de bicarbonato de sódio, torna-se a pedra de crack. Importante salientarmos que a pasta base é a mesma matéria-prima da cocaína inalada, ao menos nesta região da cidade, conforme informações de interlocutores que tiveram oportunidade de trabalhar no feitio do crack e da cocaína. Portanto, são falaciosas as informações que tentam assemelhar o crack consumido na Cracolândia a uma espécie de subproduto da cocaína.

As pedras de crack são comercializadas no varejo, em um grande número de pontos de venda ou "biqueiras", por pessoas com maior ou menor vínculo com a estrutura do tráfico de drogas. Um "vapor", como são alguns de nossos interlocutores, não é muito mais que um usuário de crack, momentaneamente incumbido de abastecer de pedras, certo local de consumo. Porém, este mesmo "vapor", que obtém estas pedras em um ponto de venda com outras pessoas de vínculos mais estreitos com o tráfico, nem sempre é usuário de crack. No local de uso, seja ele um fumódromo ou na Cracolândia, ${ }^{1}$ outros papéis sociais são desempenhados além do de "vapor", geralmente por outros usuários de crack, mas também por não usuários, como os papéis de "disciplina", "sintonia" e "contenção."

O uso do crack por nós estudado pode ser classificado como um uso forte, ou uso pesado da droga. Através da observação participante pudemos acompanhar pessoas em três

1 Usamos o termo Cracolândia por ser assim que os frequentadores do local a denominam.

2 Pessoa responsável pela segurança em uma "biqueira". Pode ser também o usuário indicado para garantir as boas condições ambientais e de insumos a uma roda de crack. 
ambientes de consumo: uma "biqueira" com fumódromo em local fechado; uma "biqueira" com fumódromo em local aberto; e a Cracolândia. Nestes ambientes de consumo e venda da droga, regiões psicotrópicas, pudemos observar a dinâmica de comercialização e uso da pedra, como as negociações envolvendo preço e qualidade, os diferentes padrões de uso, sua evolução com o passar das horas e os conflitos de interesses entre diferentes atores. O fumódromo e a Cracolândia são ambientes de grande agitação, com uma gama de interações entre seus frequentadores. Estas interações costumam girar em torno dos mais diversos temas, mas daremos destaque àquelas desenvolvidas em torno da "treta", ou no intercâmbio de bens e serviços. Nos ambientes do fumódromo a céu aberto e da Cracolândia, é o barraco que se destaca como local capaz de proporcionar o contexto mais propício ao uso da pedra. ${ }^{3}$ O uso do crack também exige, além do ambiente propício, uma parafernália de uso cujos itens entram no circuito da "treta". Esta parafernália tem no cachimbo seu mais complexo e instigante componente, ele é um mediador sempre disponível à ação criativa do usuário que o reconstrói continuamente ao sabor das mudanças ocorridas em seu corpo, no decorrer do uso da pedra. Caso o usuário esteja mais ou menos desperto, alimentado ou descansado, ele poderá ajustar o cachimbo aos seus diferentes estados corporais.

A pesquisa, baseada na observação participante, nos permitiu acessar informações que de outra maneira não estariam à disposição, como no caso dos estudos levados à frente a partir de entrevistas semiestruturadas em ambiente controlado. Nosso trabalho se aproxima de outros realizados a partir da pesquisa de campo, porém, se diferencia destes por não termos acessado nossos interlocutores como redutor de danos e

3 Não sem motivo, a Prefeitura do Município de São Paulo precisa lidar com forte resistência a desmontagem de barracos na Cracolândia, após a implementação do Programa DBA. 
ao mesmo tempo antropólogo, ou como antropólogo disfarçado em redutor de danos. ${ }^{4}$ Assim, pudemos conviver com os usuários de crack e entrar em contato com sua cultura marcada por toda uma terminologia própria, rituais de uso, papéis sociais, trocas de objetos, corporalidade, tecnologias para o abrigo e sexualidade. De tal modo, podemos demarcar como objetivo central da pesquisa: a descoberta das características e significados do comportamento ritualizado relacionado ao crack. O achado mais importante é que estes comportamentos fornecem uma infraestrutura para o processo de autorregulação controlador do uso.

Para análise dos dados levantados na pesquisa, e ainda mais, como guia de nossa observação e mesmo de nosso comportamento no campo, nos valemos de todo um arcabouço teórico e metodológico, alguns, já consagrados no Brasil, ${ }^{5}$ América do Norte $^{6}$ e na Europa Ocidental. ${ }^{7}$ Apenas para citar os mais importantes em influência sobre nosso tratamento da questão da cultura do uso de drogas. Todos estes trabalhos são fortemente influenciados pelas contribuições seminais de Howard Becker sobre o uso da maconha. Originalmente publicado em 1963, o livro Outsiders associa a problemática do desvio à teoria da rotulação, meio século depois constitui-se em um clássico. Gilberto Velho manteve profícuo intercâmbio com Becker desde, pelo menos, o ano de 1976, quando Becker foi professor-visitante no Museu Nacional do Rio de Janeiro. Além de Becker, outro autor fundamental para nosso trabalho e para a antropologia brasileira, segundo Velho, é Erwing Goffman:

4 No primeiro caso, trata-se da pesquisa de Luana Malheiros, no segundo de Taniele Rui.

5 Ver os trabalhos de Velho (2002), MacRae e Simões (2000) e Fernandez (2007).

6 Os trabalhos norte-americanos são prioritariamente os de Becker (2008) e de Zinberg (1984).

7 Uma importante contribuição teórica pode ser vista em Jean-Paul Grund (1993). 
"Becker e Goffman são hoje autores fundamentais dentro da antropologia que se faz no Brasil, particularmente nos trabalhos voltados para os estudos urbanos e para a temática ampla de individuo e sociedade". (VELHO, 2002, p. 13, grifo do autor) O tema do estigma para Goffman, tanto quanto as discussões sobre desvio e rotulação em Becker, marca, sob a influência de George Herbert Mead, uma preocupação com as interações interpessoais face a face em situações concretas, no caso de Goffman e sinaliza a ideia de uma ação coletiva em Becker. Estes dois autores pioneiros da Escola de Chicago possuem também uma imensa preocupação com a qualidade do trabalho de campo e terão influência decisiva no desenrolar de nossa pesquisa.

É também sob a influência decisiva de Howard Becker que Norman Zinberg escreve o ainda clássico Drug, set and setting, publicado em 1984. Nesta obra, o autor conclui, após se debruçar sobre o uso de heroína por veteranos da guerra do Vietnã, que não seria mais possivel, para entender a experiência com a droga, limitar-se a farmacologia $(d r u g)$ e a personalidade do usuário (set), mas também deveria-se atentar ao ambiente (setting) físico e social em que o uso ocorre. O setting proporcionado pela guerra não permitia que sanções sociais de controle e rituais tivessem chance de se desenvolver. Mas, assim que os abusadores de heroína foram retirados do ambiente nocivo, o abuso virtualmente cessou e, ao prosseguir suas pesquisas com outros usuários de heroína, Zinberg percebeu a existência de numerosos padrões de uso, como usuários de final de semana e mesmo usuários ocasionais de longa duração.

Portanto, mesmo uma droga como a heroína permite diversos padrões de uso e este uso é amplamente influenciado por sanções sociais e rituais disponiveis, ou não, no setting. A obra de Zinberg (1984) - feita a partir de uma ampla pesquisa com usuários de maconha, heroína e a $\mathrm{LSD}^{8}$ - provocou uma profunda mudança em como o uso de drogas era visto até en-

8 LSD - Dietilamida do Ácido Lisérgico. 
tão. Porém, antes mesmo de Zinberg chamar a atenção para a importância do ambiente de uso, Timothy Leary (1999) já havia descoberto, a partir de suas pesquisas com o LSD, a importância de se preparar um ambiente propício à obtenção dos efeitos desejados da droga.

Este modo inovador de olhar o uso de substâncias tornadas psicoativas rende frutos e têm no trabalho de Jean Paul Grund uma importante contribuição para seu aprofundamento. $\mathrm{O}$ autor parte dos dados obtidos em uma pesquisa etnográfica com usuários de heroína e cocaína na cidade de Roterdã/Holanda. Nesta pesquisa, se observou uma disparidade entre as consequências funestas do uso de substâncias entre as populações de surinameses e holandeses, principalmente. Os primeiros ingeriam uma quantidade maior de substâncias, sem necessariamente terem maiores prejuízos em comparação com os usuários holandeses. Pelo contrário, devido aos seus vínculos comunitários e obrigações como traficantes de drogas, os surinameses acabavam por gozar de uma melhor estrutura de vida que os usuários holandeses, ou seja, possuíam uma quantidade maior de vínculos afetivos, compromissos, obrigações e responsabilidades capazes de lhes proporcionar uma melhor relação com o uso da cocaína e da heroína. Além disto, a disponibilidade da droga se revelou na pesquisa, um elemento importante para possibilitar o desenvolvimento de rituais voltados à preservação da saúde ao invés dos dirigidos, preferencialmente, à obtenção de fundos para aquisição de cocaina e heroína. Neste quesito, novamente os surinameses, por sua proximidade com o tráfico, se saíam melhor que os usuários holandeses.

Esta abordagem teórica rendeu, no Brasil, importantes trabalhos no campo da pesquisa antropológica do uso da cocaína inalada e fumada. No primeiro caso, se destaca o trabalho de Osvaldo Fernandez; nele se descortinam as regras, padrões e métodos de uso entre usuários experientes de cocaína, assim como sua visão de mundo em diferentes territórios da cidade de 
São Paulo. Ainda neste trabalho, o consumo controlado (light) de cocaína inalada é comprovado pela presença de interlocutores com longo histórico de uso sem maiores consequências deletérias. A cocaína fumada foi objeto de estudo dos trabalhos de Luana Malheiros (2012; 2013). Eles enfocam a cultura do uso do crack na região central da cidade de Salvador/BA, e neles, a autora pôde diferenciar os usuários de crack por uma graduação quanto ao uso mais ou menos controlado; assim, surgem os "patrões", os "usuários" e por fim os "sacizeiros", ou usuários descontrolados.

O trabalho de Fiore (2013), também sobre cocaina inalada, teve como base de dados dez conversas com amigos do pesquisador, além de sua própria experiência como usuário de substâncias psicoativas. Assim como, neste livro, a Teoria do Ator Rede $(\mathrm{TAR})^{9}$ serve como referência teórica para tratar de não humanos como actantes, ou seja, capazes de fazer agir. Fiore irá, além da TAR, valer-se de uma adaptação "antiana" das ideias de Zinberg e, se para este clássico do pensamento social sobre o uso de psicoativos se trata de observar o máximo de relações entre Drug, set e o setting do uso, para Fiore as relações se darão entre substância, sujeito e evento. Assim, ele acredita poder fugir das vicissitudes modernas tão amplamente divulgadas por Bruno Latour (2000, 2001, 2008, 2012) e pelos demais seguidores da TAR, principalmente, a separação entre natureza e cultura. Citamos acima, alguns trabalhos brasileiros e norte-americanos produzidos a partir das ideias seminais de Howard Becker. Certos pesquisadores dos fenômenos em torno do consumo de substâncias psicoativas ligados a TAR serão críticos dos trabalhos que tem em Becker sua referência seminal. Dentre estes autores, Fiore destaca os seguintes: Vargas (2006), para quem o uso de drogas pertence à ordem do evento e não do contexto social e Gomart (2002) que considera

9 Neologismo criado por nós a partir da sigla na lingua inglesa para Actor Network Teory (ANT). 
os trabalhos sob inspiração de Howard Becker como reproduções do determinismo moderno ao separar natureza (droga) e cultura (significado atribuído aos efeitos). Mas, segundo Fiore (2013), estes autores não teriam conseguido nestas críticas: “[...] ao menos no campo de investigação sobre drogas, um conjunto de ferramentas metodológicas para a demonstração de seu projeto de conhecimento sobre as drogas e seus usos, ao menos um que se destacasse claramente daqueles já utilizados pelas ciências sociais". (FIORE, 2013, p. 14)

Trabalharemos com a ideia do consumo de substâncias psicoativas em certos contextos sociais e não com a noção de evento, por considerarmos o último pouco capaz de servir como instrumento teórico apto para a análise de comportamentos ritualizados como são os relacionados ao uso do crack. Verificamos em campo, o aspecto repetitivo das diversas práticas associadas ao uso. Mais que uma sucessão de casualidades fortuitas, aleatórias, ocasionais, ou seja, eventuais. No consumo do crack, a repetição, ao contrário, está intimamente associada a rituais, regras e valores de certa maneira permanentes no tempo e disseminados no espaço do centro da cidade de São Paulo. Os usuários de crack não estão invariavelmente perdidos no paradoxo, como nos gostaria de fazer acreditar Vargas. Muito pelo contrário, eles desenvolvem uma rica cultura de uso que lhes permite esperar certos comportamentos de seus pares, assim como lhes possibilita ter certa ciência de como devem comportar-se no decorrer das diversas interações que venham a estabelecer em sua "caminhada". ${ }^{10}$ Para nós, acreditar que o uso de drogas está intrinsecamente ligado à vida intensa é desconsiderar certa extensão intensa dada na rotina; no cotidiano de usuários diários de drogas que, por mais de uma década, às vezes duas, vêm fazendo uso constante e têm no crack seu "feijão com arroz". Também não encontramos nenhum usuário

10 A "caminhada" pode representar mais literalmente um longo trajeto, assim como, a própria história de vida do usuário é sua caminhada. 
experiente de crack que declarasse usar a droga para "sair de si", ou algo semelhante, muito pelo contrário, o ato de "brisar"11 pode ser inclusive mal visto pelos pares, enfim, os efeitos não devem ser algo a escapar do usuário.

O livro também teve sua "caminhada" e no momento da organização resolvemos dividi-la em duas partes. Na primeira, se apresentam as considerações a respeito dos desafios da pesquisa de observação participante entre os usuários. Discutimos os dilemas éticos e dificuldades operacionais do investigador participante e nos valemos de descrições das atividades de pesquisa retiradas de nossos cadernos de campo. Mostramos a importância de termos tido um interlocutor que se dispôs a nos ajudar a acessar o campo e, em seguida, descrevemos o uso do crack em uma "biqueira" com fumódromo em local fechado. Neste contexto, pudemos observar com cuidado as técnicas de uso e começamos a nos interessar em compreender, além do cachimbo, as relações intrafamiliares e entre traficante/usuária e demais usuários. Descrevemos como pudemos também ter acesso a uma "biqueira"12 com fumódromo em local aberto e, aí, desvendar uma dinâmica que de certa forma se repetiria na Cracolândia, com seus papéis, como o de "vapor" e "contenção", além de sentimentos como a "sintonia". ${ }^{13}$ Os dilemas éticos ocorrem fortemente relacionados às atividades ilícitas por nós vivenciadas, assim como questões relacionadas à participação nas rodas de crack e às consequências para a segurança dos interlocutores e mesmo à saúde e relacionamentos do antropólogo.

Após as considerações metodológicas e éticas poderemos adentrar na cultura do crack propriamente dita, no capítulo

11 O termo "brisar" pode ser entendido como sentir, mas também deixar transparecer os efeitos do crack.

12 Como são conhecidos os locais de venda e, por vezes, também, de consumo de crack.

13 "Sintonia" é o termo utilizado pelos interlocutores para designar o sentimento agradável de empatia entre usuários de crack. 
intitulado: "A roda de crack: cultura material, corporalidade, padrões e rituais de uso na região central da cidade de São Paulo". Temos aí, a descrição e análise da parafernália utilizada para fumar crack, particularmente do cachimbo, descrito a partir de suas partes constitutivas, até as técnicas de uso deste mediador por excelência. Do cachimbo passamos à roda de crack, e desta para o fumódromo com sua hierarquia, papéis e personagens, assim como com suas relações sociais estabelecidas no "corre" e na "treta". Descreveremos as técnicas envolvidas na obtenção de um bom "trago"14 e também da "brisa", para posteriormente os relacionarmos com os três contextos da roda de crack.

Delinearemos o papel de artesão desempenhado por Amélia na "biqueira" com fumódromo em local fechado; também adentraremos nos barracos da rua São Paulo e no "fluxo"15 da Cracolândia, todos eles, territórios psicotrópicos de uso e consumo de crack. Dados de nossa pesquisa e outras fontes bibliográficas serão analisados utilizando-se o modelo teórico de Howard Becker. Assim, procuramos verificar a pertinência de um modelo construído a partir de pesquisa com usuários de maconha, que Becker considera como incapaz de provocar dependência, e nossa pesquisa sobre o uso do crack, substância geralmente considerada causadora de séria adicção. Veremos então como, em certos aspectos, podemos falar da importância dos pares no aprendizado da técnica de uso do crack e de sua relevância também para a fruição dos efeitos desejados. Considerar o desejo e mesmo a necessidade dos usuários de crack de ter amplo

14 O "trago" é a unidade de consumo do "bloco". Pode significar tanto a quantidade colocada sobre o cachimbo, ou "boris", quanto o ato de fumar. Alguém, ao "favorecer" outro, pode referir-se ao pedaço do "bloco" ofertado como "trago", "está aí seu trago" e quem recebeu o pedaço da pedra, ao fumar, pode observar: "agora, vou dar meu trago". "Dar um bom trago" pode ser considerado o objetivo final do usuário e para tanto há de contribuir uma série de fatores.

15 O "fluxo" é a aglomeração de usuários de crack na região da Luz, em São Paulo. O fruir coletivo da pedra pode também ser chamado de fluxo. 
acesso às fontes de fornecimento, que no caso dos usuários de maconha, estudados por Becker, os leva a um maior contato com os demais usuários, nos auxiliou a compreender a existência de territórios de venda e uso que chegam a tornarem-se espaços de atração tão fortes a ponto de os usuários de crack estabelecerem lá, seu local de moradia. A carreira do usuário, nestes casos, se torna uma carreira de progressiva exclusão da sociedade abrangente e de inclusão em um grupo desviante organizado. Isto tem grande impacto sobre a concepção da pessoa sobre si mesma. Perceber que para alguns usuários existe certo objetivo de incorporar a máxima "sou da marginália, sou do crack", nos diz algo a respeito de uma identidade desviante advinda de um sentimento de destino comum. Porém, estes usuários também são capazes de desenvolver um repertório de respostas ao estereótipo do "nóia" e mesmo de construir uma autoimagem positiva e vão além. Edificam uma vida cotidiana em torno do uso do crack que preenche o tempo diário com atividades como a busca por meios para sustentar o consumo, as relações afetivas, "o corre", "a treta", a manutenção a todo instante do barraco, as conversas e uma grande gama de atividades condizentes com a situação de rua. Sugerimos assim, a existência de uma "dependência social" de todas estas relações, vínculos e práticas proporcionadas pelo uso do crack.

Após nossas conclusões, influenciadas pelo modelo de Becker, nos debruçamos sobre a obra de Norman E. Zinberg que, como já mencionamos, publica um trabalho absolutamente fundamental para a compreensão da questão do uso de drogas sob uma perspectiva social, Drug, set, and setting: the basis for controlled intoxicant use. O livro saiu publicado no ano de 1984 pela Yale University Press e a pesquisa foi realizada após mais de 20 anos de experiência clínica do autor, médico e professor de psiquiatria clínica na Universidade de Harvard. O trabalho de Zinberg segue a mesma linha teórica de Becker e Timothy Leary ao destacar a importância do ambiente no qual se consome drogas sobre seus efeitos e padrões de uso. 
Tanto quanto para Zinberg (1984), o cotidiano entre os pares revelou-se de grande importância para nossos interlocutores. Assim, o prestígio adquirido pela observação de certos preceitos e máximas, ou sanções sociais, como prefere Zinberg, pode ser considerado importante fator de controle sobre o uso do crack, tendo em vista que eles tendem a limitar o consumo da droga. Vimos também a importância dos rituais de uso do crack no sentido de evitar a "paranoia" e "favorecer a sintonia" entre usuários, tanto quanto de manter a coesão da roda de crack pela observação de certos valores como a reciprocidade e a confiança.

O modo como um indivíduo usa drogas é, em Zinberg (1984), influenciado pela maneira como seus associados as usam, ou seja, sujeitos controlados tendem a conhecer mais usuários controlados que compulsivos. Eles também possuem uma rede mais ampla de conexões sociais - um grupo de pares mais largos - os provendo de retorno valorizado e reforço para o uso moderado. Enquanto sujeitos compulsivos, que tendem a conhecer mais usuários pesados e menos usuários controlados, também costumam ser mais solitários, além de excluídos da influência dos mais moderados.

A situação de rua revelou-se, em nossa pesquisa, como o ambiente privilegiado para alguém relacionar-se com outras pessoas que fazem uso cotidiano de crack e Corote ${ }^{16}$, especialmente. Para poder estar no "corre", principalmente os de tipo mais arriscado e no intuito de sobreviver às noites perigosas da região central, muitas vezes sem dispor de um barraco. ${ }^{17}$ Observamos como é fundamental, no sentido de manter-se alerta para suportar sua "caminhada", a companhia de outros

16 Marca de cachaça muito barata e vendida em garrafas PET.

17 Mesmo aqueles que possuem um barraco estão constantemente sujeitos a interrupções constantes, como no caso de uma "biqueira" a céu aberto, o que dificulta sobremaneira o sono. 
"parças"18 na mesma situação, dispostos a manter seu uso sem cair no papel de "parasita". ${ }^{19}$ Portanto, a companhia de "parças usuários fortes" ${ }^{20}$ de crack é uma maneira de sobreviver na rua, fato que corrobora a ideia central a Zinberg, relativa à importância do grupo de pares sobre o padrão de uso.

O grupo de pares, nos locais que foram objetos de nossa observação participante, pode ser visto também como sendo capaz de formar uma "communitas" espontânea, como foi concebida por Victor Turner a partir da análise de obras literárias e exemplos históricos. Esta forma de colocar a questão da sociabilidade no território nos foi de grande importância como um recurso analítico para compreender o ambiente proporcionado pelo uso do crack e sua atração sobre os "craqueiros". O uso do crack é coletivo nestes locais e o seu uso possibilita a vivência de uma sociabilidade semelhante à "communitas" espontânea que, segundo Turner, seria procurada tanto pelos hippies quanto por S. Francisco de Assis. Nela, a pobreza é algo fundamental, por permitir a manutenção de um estado desestruturado das relações sociais e possibilitar relações fraternais entre despossuídos, marcadas em nossa pesquisa, pela reciprocidade das trocas na "treta". Ela tende a se distanciar das relações baseadas em "pessoas sociais" com funções estruturadas. Estas, mais ligadas aos membros muitas vezes circunstanciais do tráfico de drogas, como o usuário ou "vapor".

Após termos compreendido o papel da "communitas" e de termos nos aprofundado nas ideias de Howard Becker e Zinberg, é que pudemos apontar o erro presente no estigma desqualificante do zumbi. Somente após compreendermos o cotidiano do usuário e suas variações corporais entre vigilia e sono, fomos capazes de determinar a situação na qual sonho

18 Colegas de "caminhada".

19 Usuário sem disposição para fazer seu "corre".

20 "Usuário forte" é um termo nativo para designar aquele que faz uso de grandes quantidades de crack. 
e vigília se misturam e, principalmente, avaliar ser este estado apenas uma parte da totalidade correspondente ao ciclo de uso. Assim, nos foi possível apontar como o estigma do zumbi toma a parte pelo todo. O trabalho de campo e os dados daí extraídos pela interlocução com usuários de crack nos permitiu trabalhar a teoria a respeito da importância contexto social do uso de drogas em diversos momentos. Portanto, autores como Zinberg e Becker irão nos acompanhar por todo o livro. O mesmo ocorrerá com certos personagens cujos depoimentos sejam pertinentes em mais de uma oportunidade. Nos desculpamos previamente caso isto torne a leitura um pouco repetitiva.

Gostariamos também de deixar claro que este livro tem como tema principal o uso do crack, seus rituais, cultura material e padrões de uso. Tratamos, por um entendimento teórico, do contexto social em que este uso ocorre. Temas como crime organizado e outros pertinentes a pesquisas com população de rua irão apenas tangenciar nosso trabalho. Para não perdermos nosso foco e a especificidade de nossa contribuição.

Na última parte desta obra estudamos duas experiências de mudança no contexto social do usuário de crack e suas consequências. A primeira delas é o Programa DBA e a segunda são os times de futebol. Para analisar as razões do sucesso do Programa DBA, levamos em conta o trabalho de Grund (1993) sobre usuários de cocaína e heroína em Roterdã. Para ele, estrutura de vida, disponibilidade da droga e rituais e regras constituem uma triade retroalimentada capaz de influenciar decisivamente no controle sobre o uso de drogas. No Programa DBA, a estrutura de vida é construída no processo de adesão e permanência no Programa, a disponibilidade da droga, fundamental para a construção de alternativas de vida cotidiana não centrada em rituais e regras para sua aquisição da droga, é garantida pelo tráfico a varejo existente no "fluxo". A renda obtida pela participação nas atividades de zeladoria é garantia de sustento do uso de crack e ajuda a promover a evolução do usuário 
para uma situação estabilizada. Em lugar do "corre" cotidiano vem a remuneração semanal, previsivel e suficiente para um uso satisfatório de crack sob o ponto de vista do usuário.

No último capítulo deste livro trataremos do jogo de futebol entre usuários de crack da região escolhida como objeto de nossa pesquisa e, para tanto, iremos nos valer do trabalho de Goffman e McGinnes (1961) sobre os jogos absorventes. Veremos como o futebol fornece a possibilidade de grande absorção em seu interior, pelo enquadramento gerado pelas regras de irrelevância. Este envolvimento profundo permite ao orientador socioeducativo trabalhar tecnicamente os jogadores aumentando sua interdependência, sintonia e orquestração. A vontade de jogar e de vencer leva à participação em campeonatos e a deslocamentos para realidades fora daquelas próprias ao cotidiano da rua. Assim, no pós-jogo, o professor, como é chamado o orientador socioeducativo, oferece uma série de serviços, como a retirada de documentos, e indica outros rumos a serem seguidos pelos jogadores. No entanto, essas aberturas de perspectivas só logram êxito com o acompanhamento do jogador pelo professor. A mudança no padrão de uso do crack só é possivel no contexto de um ambiente socioeconômico onde o mercado de trabalho se mostra menos excludente e pela mudança na estrutura de vida do usuário gerada pelos compromissos advindos dos ciclos de treinamentos e jogos.

Marcamos em itálico os trechos que o autor considera como mais relevantes para o entendimento de determinado assunto. Trechos de conversas e algumas declarações e palavras dos interlocutores poderão também aparecer em itálico. Ressaltamos que as informações verbais dos interlocutores entrevistados durante a pesquisa foram mantidas com suas expressões originais. Os termos nativos ou gírias estarão entre aspas. Acrescenta-se a confecção de um glossário ao final do livro trazendo o significado de algumas gírias ou termos nativos em seu contexto de uso. Como o(a) leitor(a) já pôde perceber, este livro 
foi escrito na terceira pessoa do discurso como recomenda a metodologia de pesquisa. Deixaremos o uso da primeira pessoa apenas para as narrativas etnográficas. Os trechos retirados diretamente do caderno de campo serão apresentados em corpo do texto com a letra menor do que o restante da obra.

No zelo pelo compromisso ético com a preservação do anonimato dos interlocutores, a construção de alguns personagens foi prejudicada. Assim, o(a) leitor(a) terá de lidar com a frustração de ter algumas histórias pessoais sem conclusão. Chegamos até a nos obrigar a usar o recurso de dividir certos interlocutores em mais de um personagem; novamente ressaltamos, para a preservação do anonimato. Teremos então, pessoas que surgirão com detalhes econômicos a respeito de suas identidades. Pedimos vossa compreensão.

Uma outra advertência sobre os personagens retratados aqui e seus depoimentos é que devido ao fato deste livro conter, propositalmente, uma boa quantidade de explanação teórica, a mais clara possivel - ela se dá com a intensão inequívoca de fornecer um arcabouço sobre o qual o(a) futuro pesquisador(a) possa orientar seu trabalho de campo e posterior análise. Os personagens e seus depoimentos serão mencionados por toda esta obra. No seu início, podendo retornar mais à frente e novamente em seguida, sempre que se faça necessário para exemplificar a teoria ou demonstrar um argumento. Procuramos, por isso, relembrar sempre que necessário os dados biográficos fundamentais à compreensão do texto.

Nosso trabalho não ocorreu sem mudanças de rumo. Inicialmente, pretendiamos pesquisar o uso controlado de crack, porém, o campo nos levou ao uso intensivo em fumódromos e nas ruas. Seguimos o campo e em dado momento fomos colocados frente à questão de persistir a etnografia e passar a usar crack com nossos interlocutores, ou abandoná-la. Esta decisão foi tomada no campo, sem prévia discussão com o orientador e foi de exclusiva responsabilidade do pesquisador. O uso do 
crack se deu em cerca de uma dezena de oportunidades e não se apresentaram motivos para sua persistência findada na pesquisa. Ele nos permitiu ter acesso aos ambientes de consumo, nos quais não faz sentido permanecer sem estar fazendo uso da droga. Além disto, pudemos compartilhar e compreender a "sintonia" entre os usuários de crack que é caracterizada por um forte sentimento de empatia. 


\section{O USO DO CRACK COMO ELE É: PESQUISA OBSERVAÇÃO PARTICIPANTE ENTRE USUÁRIOS DE CRACK}

"Porque a pedra, ela só... ela abre caminho.” ${ }^{21}$

No presente capítulo será discutido não só os dilemas éticos, mas também as dificuldades operacionais do trabalho de campo entre usuários de crack na região central de cidade de São Paulo. Para isso, nos valemos de descrições das atividades de pesquisa retiradas de cadernos de campo e sua posterior análise, a partir da literatura sobre metodologia e ética da pesquisa.

A prática etnográfica baseia-se na pesquisa de campo com observação participante desde os primórdios da antropologia cultural. (BERNARD, 2008) Envolve aproximação e serve-se da observação e anotação de informações acerca da vida de pessoas capazes de se sentirem suficientemente confortáveis com a presença e proximidade do pesquisador. Além disso, permite certo tipo de conhecimento experimentado que possibilita uma fala convincente sobre o tema pesquisado a partir das entranhas do etnógrafo. Pode ser um depoimento sobre o consumo de ecstasy e uma noite inteira de dança em uma rave no Rio de Janeiro (ALMEIDA; EUGENIO, 2008), ou a respeito de se passar a mesma noite usando crack no centro de São Paulo. ${ }^{22}$ Cabe ressaltar que nem todo trabalho de campo é observação participante, mas toda observação participante é trabalho de campo, pois coloca o antropólogo onde a ação acontece e permite a coleta de dados como histórias de vida e a observação de comportamentos que podem ser, posteriormente, cotejadas com as verbalizações sobre eles. Pode-se participar de rituais e conver-

21 Salomão, usuário de crack na região do Cambuci.

22 Seria razoável esperar a atenção dos formuladores de políticas públicas sobre o tema das drogas a pesquisas qualitativas levadas a cabo sobre este tema, porém, isto, aparentemente, ainda não ocorre. 
sar sobre temas sensiveis, aprender o linguajar e experimentar um estilo de vida tanto quanto for possivel. É importante a capacidade de agir de modo a permitir o "fluir" do cotidiano ao seu redor, adquirir conhecimento necessário para saber quando rir e onde está a graça, assim como para fazer rir propositalmente. A observação participante consiste em imergir em uma cultura e aprender como sair desta imersão para intelectualizar a partir do que foi visto, escutado e experimentado; e depois, colocar tudo em perspectiva e escrever convincentemente. Portanto, os pesquisadores de campo são instrumentos de coleta de dados e de análise destes dados, aperfeiçoados pela prática. Trata-se de estar pessoalmente interessado nas ocorrências do local, inclusive fofocas, de apresentar-se de cada vez mais de acordo com o jeito nativo para acessar os detalhes da vida familiar, da preparação ou obtenção e consumo dos alimentos e da toalete, por exemplo. Ater-se às habilidades de manufatura, como, por exemplo, confeccionar o cachimbo de tragar o crack, analisar as querelas, as cenas de uso, fatos usualmente triviais, embora, muitas vezes dramáticos e sempre significativos.

Aparentemente, pelos relatos de experiências etnográficas, quanto mais vezes se é visto, menos preocupação se causa, até se tornar despercebido. Num ambiente de atividade proibida e perseguida, como o do uso crack, devido ao constante risco de investidas punitivas por parte da polícia, a recepção aos desconhecidos e a vigilância são atividades exercidas a partir de certos papéis, como o de "contenção" de determinada "biqueira”. Em uma "biqueira”, com possibilidade de permanência para socialização e consumo do crack, mesmo o desconhecido se apresentando acompanhado de antigo frequentador, ele será alvo da inquirição a respeito de suas credencias para lá estar. De quem é conhecido? Qual o seu propósito? O antropólogo descobrirá que o cardápio de motivos para se estar ali não é muito variado: ou irá adquirir droga e rapidamente se retirar, ou irá consumi-la no fumódromo. Caso não tenha papel acei- 
tável será imediatamente convidado a "fazer o peão", ou seja, retirar-se do local e só retornar caso possa se encaixar em algum papel aceitável.

As primeiras incursões ao campo foram realizadas na região do centro de São Paulo, conhecida como Cracolândia, nas tentativas iniciais, nem sequer foi possivel chegar ao local, demorando-se o pesquisador no reconhecimento dos arredores. Nas primeiras oportunidades de adentrar na cena de uso, observava-a, geralmente, a certa distância sem conseguir deter-me entre os usuários de crack. Foi encontrado um lugar de observação em um bar situado em frente a certo espaço utilizado para o consumo de crack. Lá, podiam-se beber garrafas de água e sentar-se ao balcão ou em uma das três mesas disponiveis, obter informações com os frequentadores e conversar com os usuários, presenças habituais no estabelecimento para comprar cigarros, isqueiro, salgados, além de presenciar a dificuldade destes para usar o banheiro. Foi possivel testemunhar o drama de uma usuária expulsa do bar; ao procurar saber do balconista as razões para esse tipo de tratamento, soube que se alguém não consome, não há como justificar seu uso do banheiro e o respectivo gasto com água. Pôde-se presenciar um pouco das dificuldades enfrentadas por mulheres usuárias para manterem a higiene na rua. Fora do bar, na calçada em frente, ou na rua, entre os usuários de crack, a situação não é tão diferente, caso não se esteja lá para fumar crack, não há como permanecer sem causar algum incômodo. Assim sendo, aos poucos, este pesquisador foi compondo um visual adequado à permanência e circulação na cena. Para Edward MacRae (2004), em uma situação de campo deve-se, na medida do crivel, livrar-se dos signos mais obstrutivos do trabalho. As vestimentas associadas à classe média coloca o antropólogo em situação pouco confortável e digna de suspeição no campo. ${ }^{23}$ A nova indumen-

23 Em suma: "faz parecer polícia", segundo os esclarecimentos dos usuários em mais de uma ocasião. 
tária foi composta por boné, propositalmente com inscrições do cantor Bob Marley, isqueiro adquirido quando da primeira tentativa de incursão, maço de cigarros e óculos escuros, estes últimos ajudariam, como pensado na época, a esconder o olhar curioso e de não usuário - com o tempo também se tornou possivel diferenciar o olhar e os olhos do usuário de crack. O fato de não ser usuário era também denunciado pelo sobrepeso, visivel principalmente na face, como revelado depois, ${ }^{24}$ isso tudo mudou ao sermos indicados a Newman. Voltamos a usar as vestimentas mencionadas somente quando retornarmos para fazer pesquisa de campo na Cracolândia. O contato foi feito por meio de dois colegas nossos do ensino médio, ambos haviam sido, assim como nós, usuários de drogas durante a juventude e o encontro com Newman foi marcado por telefone.

\section{Acessando d "biqueira"}

A fim de não se perder a dinâmica e fruição dos acontecimentos dados em campo, passo a transcrever os trechos das anotações de meu caderno. Por vezes, de modo intercalado, serão feitas as considerações analíticas possiveis. No entanto, é preciso fazer a ressalva sobre o momento da escrita destas anotações visto que era impossivel ir a campo e fazer as anotações in loco, devido ao fato de levantar-se suspeitas imediatas na Cracolândia, mesmo posicionando-se relativamente distante dos usuários, dentro de um bar. Fato idêntico ocorria nos lugares de uso frequentados com Newman e, por isso, as notas eram escritas após retorno do campo, juntamente com as transcrições das gravações, nos casos em que foi possivel utilizar o telefone celular para realizá-las, isto permitiu um processo rico de rememorar, elaborar

24 Também havia pouco tempo para a dedicação ao campo no início da pesquisa, visto que era entre o período do pesquisador deixar a filha na escola e retornar para buscá-la 4 horas e 30 minutos depois. 
e escrever. Os três trechos que seguem abaixo foram extraídos do caderno de campo em fevereiro de 2013:

Após revelar minha condição de pesquisador e a intenção de observar o uso da pedra, Newman propôs irmos a uma 'biqueira' pegar algumas e caberia a ele demonstrar como o crack é fumado. Este será o interlocutor-chave até eu começar a ir a campo por conta própria. Estávamos excitados com os propósitos científicos de nosso trabalho. A qualificação de que faziamos ciência serviu de justificativa do uso para Newman, que pretendia abandonar o hábito. ${ }^{25}$ Ao entrarmos no carro, teve início à 'correria' e o veículo já não era mais guiado como antes, tinha se transformado em uma espécie de viatura, pois estávamos em uma missão. Nós não nos confundiamos mais com os meros membros da classe trabalhadora deixados para trás no trânsito, não agíamos mais como 'caretas', haviamos passado para o outro lado ou, pelo menos, o antropólogo em pesquisa participante havia retornado para lá, após tantos anos. As regras de circulação de veículos já não se aplicavam mais inteiramente àquela situação.

Seguimos direto para a 'biqueira' localizada em uma planta de fábrica abandonada e ocupada, aparentemente, por familias da classe trabalhadora e do subproletariado. Ainda se encontra presente o antigo portão de metal da entrada dos caminhões, testemunha do periodo industrial do bairro; por este portão também se acessa a 'biqueira' a uns 50 metros adentro. Ao passarmos por bares na entrada, fomos encarados de modo ameaçador por dois homens, disto viria saber apenas em meu segundo encontro com Newman, pois o 'olhar de frango ${ }^{26}$ e de pesquisador novo no campo, não estava ainda suficientemente treinado para perceber muitos detalhes.

Passando os bares, avistamos o 'contenção' responsável por organizar os trabalhos, ele grita aos clientes para se apresentarem com as cédulas abertas na mão e levantarem a camiseta para mostrar a cintura livre de arma de

25 Vale esclarecer que após proporcionar à entrada no campo, Newman efetivamente parou de fumar crack, voltou a trabalhar como engenheiro e casou-se.

26 Termo utilizado para designar o usuário inexperiente, considerando-o como otário. 
fogo, além de terem de girar exibindo as costas, erguer a barra da calça para deixar visivel o tornozelo. Este mesmo rapaz, aparentando menos de 30 anos, indica-nos o local rente a uma parede em que devemos nos postar em fila. São umas oito horas da noite. Uns cinco clientes estão à nossa frente, em fila, encostados ao muro, e nos postamos atrás deles. Com o espaço de alguns segundos entre um e outro, novos compradores vão chegando e ficamos assistindo ao ritual de ser alertado, levantar a camisa, dar uma voltinha e levantar as barras das calças à chegada de cada novo usuário. O ambiente é um pouco tenso devido ao esforço contínuo do 'contenção' para manter um mínimo de concentração e 'procedimento' na fila de usuários. Não é tarefa fácil. A tendência à entropia é clara. Os enfileirados querem conversar e quebrar a atmosfera hostil. Fazem piadas, brincam, comentam o atendimento, contam breves casos, tentam alertar os outros sobre o perigo em tal ou qual lugar. Reclamam. Como se estivessem na agência bancária, protestam quando um comprador fura a fila. Exigem do 'contenção' a imposição da ordem na coisa toda. Este ameaça os que insistem em permanecer papeando: 'tô avisando, é pra ficar quieto, quem continuar falando vou mandar 'pro' fim da fila, depois não vem reclamar'. $O$ rapaz a furar a fila tem aparência de classe média, 'boy', isto joga mais combustivel nas reclamações. Aparece uma moça e é atendida preferencialmente, ela se oferece para comprar para alguém da fila masculina, ele aproveita a oportunidade para também furar, novos protestos. Depois ficariamos sabendo deste detalhe de procedimento de 'biqueira': são duas filas separadas por gênero e mulher tem preferência. Como na cadeia, as mulheres são extremamente respeitadas na 'biqueira': 'afinal de contas nunca se sabe se se estará mexendo com a mulher de alguém perigoso, ou não'; observou posteriormente Newman. Enfim, não é ambiente propício ao flerte amoroso.

O comportamento descrito nos três parágrafos acima, retirados do caderno de campo, corrobora com a descrição contida na tese de doutoramento de Lúcio Garcia de Oliveira a respeito da cultura do uso do crack na cidade de São Paulo:

Já no que se refere ao comércio em si, os entrevistados caracterizam-na como bastante organizada, relatando a 
formação de filas na bocada que funcionam sob regras rígidas. Além de mulher ter prioridade, as transações são rápidas, ou seja, se não há dinheiro ou não se aceita a proposta de venda, atende-se o próximo 'cliente' e assim por diante. (OLIVEIRA, 2007, p. 93)

$\mathrm{Na}$ referida tese, discorre-se sobre a organização da fila por diferença de gênero feita por um usuário com 29 anos de idade: [...] mulher não pega fila, às vezes tem fila, então, quando tem mulher eles passam na frente dos caras, que é uma lei, então homem nunca pega primeiro [...]. (OLIVEIRA, 2007, p. 93)

Os próximos dois trechos foram retirados do caderno de campo, em março de 2013, neles, se descreve o modo de aquisição das pedras de crack com seus procedimentos e alguns riscos ao pesquisador e interlocutor:

Chega a nossa vez e nosso interlocutor compra uma da menor correspondente a um papelote com crack. Entrega uma nota de vinte reais a um homem aparentando uns trinta anos, o qual segura com as duas mãos um saco plástico branco, do tipo dos usados em supermercado, que está cheio pela metade com papelotes de crack e de cocaina ou 'da maior'. Ele reclama um pouco por ter de dar troco, que é providenciado por um rapaz aparentemente menor de idade sentado em um banquinho de madeira com um bolo de notas na mão abertas em leque. Ele recebe a cédula de $R \$ 20,00$ passada pelo homem com a sacola contendo os papelotes e entrega o troco a meu interlocutor. Ao receber a droga se é imediatamente convidado a retirar-se do local. Saimos pelo mesmo caminho de entrada e paramos no bar próximo ao portão para comprar cigarros, mas as marcas de importados de baixa qualidade ali presentes não agradam meu interlocutor $e$ guia, dirigimo-nos para a calçada. Avistamos uma moça negra que, embora passasse a impressão de ser usuária, estava trabalhando para a 'biqueira' com um 'walk talk' em uma das mãos, igual ao visto na mão do 'contenção'. Voltamos à casa de meu interlocutor, onde haviamos nos encontrado pouco antes e presenciei o uso, recebi explicações e pude fotografar. 
Uma semana depois fomos os dois a outra 'biqueira', localizada em um bairro central de São Paulo. ${ }^{27}$ Avançamos por um corredor de não mais de vinte metros e encontramos dois homens com menos de trinta anos de idade que nos perguntaram quanta droga queríamos, Newman pediu duas 'da menor', ou seja, crack. Não há fila naquele horário, por instrução de meu informante parei o carro em uma rua lateral e não na rua da 'biqueira', cuidado que se revelou importante. Após sairmos e entrarmos em nosso veículo, dobramos na rua da 'biqueira' e seguimos sentido bairro, quando cruzamos com uma viatura de polícia dotada de 'side light' prontamente apontado no nosso rosto, possivelmente em busca de sinais de uso para abordagem - como ocorria naquele momento com uma dupla de jovens com aparência de classe média metros adiante - eles 'tomavam um enquadro', como nos explicou Newman, de dois policiais militares em outra viatura.

Os dois parágrafos retirados do caderno de campo e transcritos acima nos permitem pensar sobre este local de comércio de substâncias tornadas ilícitas e alteradoras do humor, a "biqueira". Ali, a repressão concentra-se no porte da droga pelo usuário enquanto a venda, ou tráfico, não é reprimida, pelo menos a ponto de fazê-lo cessar. O que poderia ser mais desmoralizante para uma política de repressão? Décadas de comércio em um mesmo imóvel? A óbvia associação da polícia ao tráfico? Afinal de contas, por que o ponto de venda não é fechado? Sequer necessita mudar de endereço, tem ponto fixo há 30 anos ou mais. Mas a resposta pode estar na possibilidade de ganhos por parte da polícia e esta possibilidade, certamente, se dá de forma diferente em relação ao traficante e ao usuário. Podemos conjecturar ser a abordagem ao usuário pela

27 É um ponto de venda de drogas ilicitas tradicional, conhecido não apenas por moradores da região, mas famoso em boa parte da cidade. Há tempos atrás, nos anos 1980, consistia em um portão de metal reforçado com uma janelinha por onde era recebido o dinheiro e entregue a droga. Este portão foi derrubado pela polícia com o uso de pesado ariete, informou Newman, crescido no bairro. O comércio passou a ser feito a partir de portão leve de grades com um adolescente dando a mesma instrução de entrar com o dinheiro aberto, visto na biqueira da semana anterior. 
polícia mais democrático, ou seja, à disposição dos policiais de plantão dispostos a permanecer nas proximidades da "biqueira" aguardando algum incauto ser pego ao acabar de adquirir seu pino de crack ou cocaína. Podemos, da mesma maneira, inferir a respeito do rateio do dinheiro obtido dos traficantes por parte da polícia para permanecerem exercendo sua atividade de modo ininterrupto durante décadas no mesmo local. Este deve "dar-se por cima", ou seja, acessivel apenas aos escalões mais elevados da polícia. O simples policial em busca de alguma substância para usar naquela noite e alguns trocados obtidos via chantagem sobre o usuário pego com certa quantidade de droga tem, provavelmente, na abordagem a granel sua motivação para rondar aquele espaço e as demais "biqueiras" da cidade prestando seu mau serviço à sociedade.

Newman chegou a descrever-nos um caso que aconteceu com ele e que ilustra certas relações possiveis entre policia, consumidores e traficantes em uma "biqueira". Certa vez, após adquirir alguma quantidade de drogas nesta tradicional "biqueira”, a que nos referimos anteriormente, ele se vê, juntamente com seu acompanhante, cercado por viaturas policiais. O carro que guiava no momento era particularmente propenso a este tipo de procedimento: um antigo modelo Ford tipo Maverick. Após ser parado para uma blitz - termo este retirado do alemão blitzkrieg, uma doutrina tática nazista. - Newman se viu na iminência de ser obrigado a contribuir financeiramente com os policiais que o haviam visto sair da do local e, certos dele estar de posse de algum "flagrante", esperavam receber seu quinhão. Não contavam eles com o fato de Newman ser antigo morador do bairro e velho freguês daquele ponto de venda. Isto motivou o "patrão da biqueira", imediatamente avisado da ação policial a poucas centenas de metros de seu estabelecimento comercial, a dirigir-se ao local da blitz e avisar os policiais que deveriam deixar aquele freguês em especial livre de sua ação predatória. No mesmo instante, segundo relato de meu interlocutor, ele se viu livre. 


\section{Participando de roda de crack em uma "biqueira"}

Conforme narrado, meu interlocutor e guia naquela noite e em algumas outras no decorrer do primeiro semestre de 2013 havia, juntamente comigo, comprado uma pedra em uma "biqueira” tradicional do bairro com décadas de funcionamento. Desse modo, seguimos como anotado no caderno de campo em março de 2013:

Passamos no caminho por uma terceira 'biqueira', na esperança de encontrarmos uma pedra e uma roda de crack, mas fomos informados do encerramento das atividades naquele local. Assim seguimos para outra dali a poucos metros, a 'biqueira' da Andressa, onde achariamos mais pedras e com quem usá-las. Caminhamos alguns metros por uma rua sem iluminação até o nosso destino. Ao chegar, dirigimo-nos a um conhecido de meu interlocutor e, após breve conversa, ele adentra pelo portão por onde logo entrariamos. Após receber nossos últimos $R \$ \$ 9,00$, quantidade insuficiente para adquirir uma pedra de $R \$ 10,00$, ele retorna com nossa encomendada. A falta de um real não foi problema devido à antiga relação entre os dois, meu interlocutor e este seu conhecido, também gerente do local. Foi-lhe perguntado se Amélia, irmã de Andressa, estaria lá e se poderíamos ir até ela. Prontamente nos foi autorizado.

Esta 'biqueira' localiza-se em um bairro na região central de São Paulo, o mesmo da 'Esta biqueira' visitada fazia pouco, em frente a um edificio sob a ocupação de sem tetos. Na entrada há um portão de metal no centro do muro à frente do terreno e ele possui, em seu interior, algumas casas. A passagem é feita por um corredor e como era noite, podem-se ver apenas as placas de madeira pelo chão sobre pedras e lama. Caminha-se ladeado por muros de outros barracos até o quarto que servirá de fumódromo, localizado após o que restou de outro cômodo derrubado, lá residem mãe e filha. A primeira chama-se Fabricia e a segunda Amélia. Ao chegarmos, apenas a última estava presente, acompanhada por Tide a quem chama carinhosamente de vó, elas fazem uso da pedra, mas no decorrer da noite outros usuários iriam aparecer. 
Ao chegar ao cômodo ${ }^{28}$ Newman foi saudado e cumprimentou Amélia com um abraço, o mesmo se dando com Tide. Fui apresentado inicialmente como primo de Newman e, em seguida, como antropólogo. Fui desqualificado como careta e isto causou certo embaraço em Amélia, ela aparentou sentir certo incômodo em usar em frente a um não usuário. Na tentativa de superar o constrangimento fui requalificado por Newman como ex-usuário de 'farinha', nome dado à cocaina aspirada e ex-interno de uma clínica de tratamento, prontamente manifestei-me sobre a minha condição de ex-usuário.

Figura 1 - "Fumaça. Sofra e morra!" -

Pichação na parede do quarto de Amélia

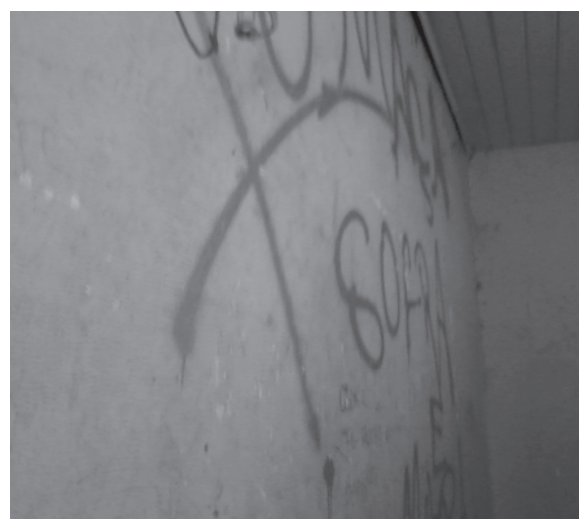

Fonte: Coleção pessoal do autor.

28 O quarto media uns $3 \times 3$ metros e estava com a terça parte coberto por roupas amontoadas que iam do colchão sobre o qual se sentava Amélia, no centro do cômodo, até a parede do fundo, chegando à altura de um metro de roupas entulhadas. Havia dois móveis baixos com aparência de balcão, ou partes de armários sobre os quais se sentava. Um deles coberto por um colchão de berço. Uma cristaleira me chamou a atenção pela beleza e cheguei a comentar com todos ali presentes da minha impressão, sendo informado de que não era o primeiro a reparar nessa qualidade do móvel. Uma parte de sofá vermelho desmembrado jazia em frente à porta, curiosamente virado com os assentos para esta. Poderia-se sentar em seu encosto ficando em uma altura não muito abaixo daqueles acomodados nos outros locais disponíveis, com exceção de Amélia localizada em um colchão de solteiro diretamente sobre o chão, na direção da porta, porém atrás do móvel com o colchão de berço, onde em breve viria se sentar Fabrícia. 
Importante comentar sobre este trecho do caderno de campo que acabo de reproduzir, que minha presença como não usuário era em si um constrangimento, só superável no futuro por uma postura mais próxima possivel do participante observador. A respeito do pudor revelado por Amélia em usar crack em minha presença, apenas tempos depois ficou claro pela pesquisa de campo um dos valores importantes entre usuários de crack: não fazer uso em frente ao "Zé povinho", ${ }^{29}$ ou não usuário. Não dar espaço para a maledicência, a crítica e o olhar reprovador, assim como não demonstrar ser desrespeitoso com os não usuários, os agredindo ao exibir o uso do crack. Retomando o caderno de campo pude perceber o clima de preocupação reinante no local:

\begin{abstract}
Existe um clima de apreensão com qualquer barulho associado à abertura do portão de acesso à rua, localizado a uns quinze metros de distância e ladeado, neste caminho, por outros barracos. Como é de metal faz barulho característico e em alto volume quando fechado com força. Qualquer sinal de presença de alguém de passagem a caminho do barraco localizado atrás ou ao lado do de Amélia e sua mãe também era digna de atenção e muitas vezes de comentário. Além de Amélia, sua mãe, Vó, Newman e eu, outros usuários ou não de crack se aproximaram e adentraram ao barraco. ${ }^{30}$ Amélia também vendia pedras tal qual sua irmã Vanessa fazia no barraco atrás daquele.
\end{abstract}

29 Termo utilizado para designar os não usuários de crack em atitude julgadora com relação aos craqueiros.

30 Um deles é um rapaz profissional de automação industrial, mas naquele momento estava desempregado. Ele e o engenheiro Newman conversam sobre assuntos técnicos, muito por iniciativa deste. O rapaz que aparenta menos de 30 anos de idade está com bom aspecto físico, não está magro, traja camisa preta, boné, calça jeans e óculos escuros. Estava do lado de fora, na rua, quando chegamos e lá o reencontrariamos quando de nossa ida embora. Nesta ocasião, ele estava acompanhado por uma moça e segundo Newman, usuária controlada de crack e garota de programa. Ela apareceu pela primeira vez justamente no momento de nossa saída para chamar Amélia até a rua. 
Nesta oportunidade, pude presenciar a avó de Amélia "brisando", assim como o uso por diversas pessoas, a roda de crack, o manejo da parafernália, a confecção de cachimbos, as exigências quanto ao comportamento adequado no local, os medos, a autoimagem dos usuários e as cobranças quanto a contribuir financeiramente para a manutenção da roda de crack.

\section{Frequentando uma "biqueira" com fumódromo a céu aberto 31}

Nos parágrafos a seguir, retirados do caderno de campo de abril de 2013, descrevemos os preparativos para, acompanhado de Newman, sair em busca de novos interlocutores em um local de uso com uma quantidade significativamente maior de usuários. Veremos como as hesitações e medos começaram a se dissipar conjuntamente com o maior contato com os usuários de crack.

Cerca de duas semanas após a visita à 'biqueira' de Amélia buscamos novamente Newman em sua casa, ele havia previamente alertado sobre o valor que deveria gastar aquela noite, estimando em $R \$$ 50,00. Alegou haver outros usuários que, provavelmente, estariam presentes em nossa roda, ele, possivelmente, calculou que a quantidade de cinco pedras fosse suficiente para o seu desejo de fumare os 'favorecimentos ${ }^{32}$ 'a fazer, mas não foi. Paramos antes em um bar. Disse-lhe para descermos do carro e tomarmos uma cerveja. Refletindo sobre o meu ato, vejo minhas

31 Não conseguia encontrar Newman na semana posterior a nossa visita à "biqueira" com fumódromo. Embora ele tivesse tentado me contatar, por causa de outros compromissos não pude ir. Ele queria, aparentemente, usar crack. Na semana seguinte, recebi uma espécie de ultimato para sairmos juntos porque ele estaria cogitando em não mais participar da pesquisa para dedicar-se a vida profissional. Ao encontrá-lo, mostrou-me uma sacola com roupas que havia lavado para uma usuária do fumódromo que eu iria conhecer naquela noite. Fiquei com a impressão, posteriormente, de que ele estava muito interessado em nosso encontro, avisou que iria "enfiar o pé na jaca".

32 "Favorecer" é o ato de fornecer parte do bloco, ou pedra de crack a outro usuário. O termo serve para demais artigos objeto de "treta", ou troca, em uma "biqueira". 
reiteradas tentativas para dar um 'ar de normalidade' ao que faziamos e iriamos fazer naquela noite ainda em seu inicio. Eram umas 19 horas 30 minutos, ele bebeu a cerveja rapidamente, compramos cigarro, isqueiro e tomei um energético para aguentar acordado. Aproveitei para ir ao banheiro, pois não existe no fumódromo. Fomos avisados ao chegar que o bar iria fechar em breve, explicamos, então, que sairiamos logo, para que fossemos servidos. Falávamos alto. Percebi um olhar diferente da balconista sobre nós, será? Saímos e resolvi retirar o lixo do carro, aproveitando uma lixeira que havia no poste ao lado. Queria deixar o veículo pronto e asseado para nossa 'balada'. Por quê? Isto dissolveria nossas intenções ilegais? O medo da pedra? Saimos.

No carro, Newman indicava o caminho à 'vapor', 33 pessoa que vende drogas em uma 'biqueira', ou seja, se ele não disser nada, é para seguir em frente, só se aponta os lados para onde se vira, uma economia de palavras $e$ de perguntas. 'Vou em frente?'A resposta seria: 'Por quê? Disse para virar?'. Estacionamos em frente a um bar do outro lado da rua com os faróis iluminando a 'biqueira' em frente. Mas ele quis me mostrar outra, a '29', no quarteirão abaixo. Fomos para lá. Ao chegarmos a um portão, sempre um portão, noto uma diferença entre a 'biqueira' de bairro e a de favela. Ao não se estabelecer a biqueira dentro de uma favela, ela necessita de separar-se da rua por porta de metal. Solidez material na falta de distanciamento social, isto também ocorre na 'biqueira' da rua Estudantes que viriamos a conhecer pouco tempo depois.

Dois rapazes com postura de poucos amigos atendiam à porta. Um deles perguntou a Newman o que este queria e reclamou de ter de dar troco, olhou para mim e perguntou se queria algo, ao tomar conhecimento de meu papel de acompanhante me mandou 'fazer o peão', ou seja, sair de lá, dar uma volta. Obedeci imediatamente, percebi que para estar com usuários de crack, assim como em qualquer outro contexto, há de se ter um papel a desempenhar. Ao caminhar em frente à 'biqueira', alguns menores questionavam minhas intenções, tive de usar a história do

33 Trata-se do vendedor de drogas. Alguém "no fluxo". Neste caso, ele se encontra fora do espaço seguro da "biqueira", ele estende o alcance desta até o meio dos usuários. 
'peão' para justificar minha presença por lá - 'Estou fazendo o peão', informei, e por isto, insisto, não se fica em um ambiente de compra ou uso sem uma justificativa, uma identidade, um papel. Newman sempre me apresenta, conta uma história, afirma ser eu tão louco quanto eles $e$ apenas observa o fato de seu acompanhante 'ter parado', antes de poder me colocar definitivamente como antropólogo. Neste sentido, somos sinceros.

Tomei distância de Newman além do necessário, por curiosidade, para ver os arredores. Depois disso, Newman vem ao meu encontro, retornamos à esquina passando pelo nosso carro e atravessamos a rua, imediatamente somos abordados pelo 'contenção'. Não se parecia com o congênere da 'biqueira' dentro da favela, mas com um usuário mais interessado em saber quem chegava para ser favorecido, do que alguém responsável pela vigilância do local. Com o tempo de campo, percebi a intrincada rede de prestações de serviços entre 'vapor(es)' e outros usuários. Ele mesmo brincou ao me ser apresentado por Newman como contenção, dizendo que faziam 'a contenção para eles mesmos', como se contasse apenas consigo para proteção própria. Newman se dirige a um barraco, um conjunto de plásticos pretos e um colchão de ar descosturado e aberto, cuidadosamente amarrados um ao outro, que vão da sarjeta até um muro e ao lado de um bueiro destampado, coberto por papelóes e plástico. O barraco de Zezé, um artista plástico carioca, conta com dois avanços laterais que não chegam a formar uma porta, mas auxiliam um pouco a isolar seu interior. Ao menos um pedaço de cobertor soma-se às lonas do teto e outros cobertores cobrem o chão próximo à parede em um criativo emaranhado que pode ser facilmente montado e desmontado como um sofá-cama. Ele proporciona um uso múltiplo e facilita a busca por objetos caídos, inclusive pedaços de pedra. A ligação com o muro é totalmente vedada até o chão. No final da calçada e após a guia, na sarjeta, o encontro da lona com o chão é sustentado por um carrinho de feira (disponivel para 'treta') e próximo ao carrinho forma-se um segundo ambiente com um colchão que faz às vezes de cama e outras cobertas, onde se pode igualmente sentar-se. Apoiado sobre o chão e encostado ao carrinho reside um espelho que reflete a luz da vela que ilumina tudo, ou quase. Todo conjunto repousa sobre placas de Madeirit e é muito confortável. 
Sentamo-nos e finda as apresentações o fluxo da pedra começa. Sou apresentado como 'loco que parou de usar', 'ex-viciado em farinha', 'aposentado', 'que conheceu a Muniz quando ainda era o portão', numa referência à 'biqueira' mais tradicional do bairro para quem calculamos ter três décadas, ao menos, de serviços ininterruptos prestados aos usuários da região central e centro-sul da cidade.

O trecho do caderno de campo que acabamos de reproduzir leva-nos a pensar sobre o início de nosso contato com o uso do crack, antes de nossa maior aproximação com este uso. Percebemos a continua e segura dissolução das noções preconcebidas até sua inversão rumo a uma maior identificação e reconhecimento dos valores morais, estéticos, dos gostos e preocupações, enfim, dos sentimentos próprios deste estilo de vida, desta parte de nossa cultura popular, a cultura do usuário de crack.

Em "biqueira" com fumódromo fica usuário e "vapor". Ir apenas observar e estar com eles é uma intromissão, causa desconforto, insegurança quando não franca hostilidade. Portanto, como fez Malinowski (1978, p. 22), cada vez mais: “Tive de aprender a comportar-me como eles e desenvolvi certa percepção para aquilo que eles consideravam como 'boas' ou 'más' maneiras."

Vimos nos parágrafos anteriores as dificuldades e artimanhas para acessar os usuários de crack. Fica patente a relevância de Newman (nosso interlocutor) como facilitador no acesso e socialização na "biqueira". Também nos começa a aparecer com maior clareza a importância ética de manter a revelação de nosso papel de pesquisador sob a responsabilidade do interlocutor, do nativo, afinal, trata-se de sua segurança no campo durante e após o término de nossa pesquisa. Qualquer atitude irresponsável e voluntarista por parte do pesquisador participante poderia colocar as amizades, reputação e mesmo a vida de nosso interlocutor e guia na introdução ao campo em risco. Contudo, em todas as situações de pesquisa, o papel de pes- 
quisador sempre pôde ser revelado em seu devido tempo. Mesmo com todas as precauções de Newman, nessa mesma noite, uma frequentadora do barraco de Zezé iria incomodar-se com o fato de lá me encontrar sem fazer uso do crack como todos os outros frequentadores do local. Isto geraria uma reclamação ao "contenção", a quem fora apresentado na chegada da "biqueira" e ele viria me ameaçar com uma faca dentro do barraco de Zezé.

\section{Quem é mais ladrão?}

Nos parágrafos seguintes, oriundos dos cadernos de campo de maio de 2013, somos levados a entrar em contato com outras atividades ilegais, além do tráfico e porte de drogas e nos deparamos com os dilemas éticos daí resultantes.

Após um mês da primeira visita à 'biqueira' da rua São Paulo, volto procurando por Zezé, responsável por instigante conversa em minha última visita ao campo. Desta vez vou só e encontro Newman no interior do beco ao lado de um carro de reciclagem puxado à mão. O encontro sentado no chão a preparar um 'boris', nome dado ao cachimbo de fumar crack, e logo me apresento a ele e ao 'contenção' que imediatamente surge para interrogar minhas intenções no local. Mostro alguns cachimbos que trouxera de recente viagem aos Estados Unidos. Estes, logo atraem a atenção e cobiça do 'contenção' e de outro usuário que estava ao lado de Newman. Vou explicando o funcionamento dos cachimbos, particularmente de uma caneta que esconde um tubo de vidro disfarçado. Em dado momento, o 'contenção' faz um movimento de pegar um cachimbo para si, mesmo sendo advertido por mim que este seria presenteado a Zezé. O cachimbo é rapidamente retirado de sua mão por Newman e, em seguida, o outro usuário a acompanhar a demonstração das novidades nos alerta do fato de Zezé haver entrado em desavenças com Russa, casada com o 'vapor' da 'biqueira', que aqui será chamado de Dobem. Ela é uma espécie de coordenadora deste e demais 'vapores' atuantes no local. Fico com a impressão de o presente para Zezé ter ficado sem dono, pois pode ser apropriado 
por qualquer um, contudo, isso não ocorre em virtude da intervenção de Newman. No local em que se localizava o barraco de Zezé havia outro de muito menor cuidado. Discuto isto com Russa logo após conhecê-la. Como observado, Russa é uma espécie de coordenadora dos 'vapores' do beco. Posteriormente, em outra visita a esta 'biqueira', viria saber por Cláudia, outra usuária de quem falaremos a seguir, do relacionamento de Russa com Dobem, como dito, um 'vapor' desta 'biqueira', relacionamento este não assumido em público. Havia ficado com esta impressão ao conhecê-la e observar o comportamento de ambos, porém, ao questionar Newman sobre a situação dos dois, este me garantiu que Dobem era 'bicho solto' (Para Cláudia, não haveria porque esconder o relacionamento entre os dois, para ela, 'a partir do momento que estão juntos é marido'). Pelo menos esta é a conclusão a que chego ao discutir seu status com Newman. Ela mesma, Russa, lamenta a falta de Zezé para manter o barraco em bom estado de conservação, mas observa que este foi expulso do beco por ter sumido com quarenta reais em moedas que ela lhe entregara para serem trocadas por cédulas. No fim das contas, o presente trazido para Zezé é dado por Newman à Russa. Aparentemente, esta como credora, acabou por fazer jus ao bem trazido para Zezé.

Dobem, o 'vapor' da 'biqueira', pede-me para levá-lo à Praça da Sé, na região central da cidade de São Paulo, distante pouco mais de uma estação de metrô do local da 'biqueira'. Ele me exibe um telefone celular. A 'treta', ou troca de coisas e dinheiro é o modo usual, além do empréstimo, de conseguir outras coisas, como as necessárias para fumar: isqueiro, cinza, cachimbo, cigarro, raspador e, principalmente, pedras de crack. Em visita anterior ao campo, chegamos a adquirir dois telefones celulares de Dobem para logo depois revendê-los dentro da 'biqueira', com algum prejuízo. A decisão de comprar partiu de $\mathrm{Ne}$ wman e a venda foi realizada por Zezé, de modo atribulado, sob pressão minha para abandonar o campo, dado meu cansaço pelo adiantado da hora. Não foi de imediato minha tomada de consciência da origem daquele bem nas mãos de Dobem, ele poderia ser fruto de 'treta', mas não, havia sido roubado pelo próprio Dobem. Em outras visitas percebi o motivo dos pedidos insistentes para levá-lo à região da Avenida Paulista. Era lá, numa região de escritórios, o lugar da realização dos roubos, mas aonde nunca cheguei a acompanhá-lo. 
Ao entrar em meu carro, Dobem começa a comentar seu desejo de comprar um veículo de chassis raspado e adulterado nos dois últimos números. Pergunto sobre como ficaria a documentação do veículo e ele responde algo sobre a origem ser de leilão. Dobem comenta sobre nossa última volta de carro em que fomos buscar dinheiro para pagar o 'bloco' consumido por Newman, de como a 'biqueira' havia ficado 'abandonada' e dele ter sido chamado a atenção. Dobem me pergunta se também roubo e explico ser professor, no máximo sonegador de fontes de rendimento no imposto de renda nos antigos tempos de viabilidade deste artificio. Aponto a ele minha 'cara de otário'. Chego a deixá-lo consternado: 'Ah, não fala assim. Você não tem cara de otário'.

Passamos ao lado da Praça da Sé e observo uma concentração, aparentemente, de usuários de crack e Dobem faz um comentário depreciativo sobre aqueles que lá se reúnem. Mais tarde, ao levar Newman para casa, este afirma estarem na Cracolândia os piores usuários, os sem condições de frequentar uma 'biqueira' melhor como a de Dobem. Na Praça da Sé ficariam os de condições não tão ruins quanto ao seu comportamento, em comparação com os da Cracolândia, mas também estariam em piores condições de conduta, em relação aos da 'biqueira' de Dobem. Ele faz a venda e retorna a nosso veículo vangloriando-se da quantia levantada, um pouco mais de cem reais a vista $e$ o restante a receber em alguns dias, totalizando, segundo ele, algo em torno de quatrocentos reais.

No caminho de volta à 'biqueira', Dobem simula apontar uma arma e disparar o gatilho na direção de uma senhora sentada no banco do passageiro de um veículo que parara ao lado do nosso em um farol. Ao nos aproximarmos da 'biqueira', Dobem pede para que se dê um 'cavalo de pau' em frente ao beco para marcar nossa chegada. Em dado momento, ao nos depararmos com uma contramão e minha negativa em prosseguir por este caminho, Dobem questiona se sou 'Vida Loka'. Termo usado para referir-se àqueles que se dedicam a um estilo de vida criminoso e também nome de um grupo musical da periferia da cidade. Faz questão de sair do carro ainda em movimento. Pode ser apenas um gosto pela emoção, mas parece mais a vivência de certo estilo de vida, 'sou da marginália, sou do crack', como um dia, e veremos a seguir, observou o próprio Dobem. Alego em minha recusa não ser mais adolescente para fazer tais coisas. Russa, esposa de Dobem, 
Jamais fomos zumbis

havia permanecido no local, para garantir o suprimento dos usuários e o funcionamento da 'biqueira'. Apresentar-se como 'Vida Loka' aos frequentadores da 'biqueira' quando possivel, aparentemente tem importância, paradoxalmente, a quem 'está na responsa', como Dobem.

Sobre o trabalho de campo observou Turnbull (1986) que ele nos propicia oportunidade para rever nossas próprias ideias e valores, nosso próprio ser. Durante este modo de pesquisa voltamo-nos para nós mesmos e abandonamos o antigo, estreito e limitado do self, para enfim descobrirmos um novo self apropriado ao novo contexto. Os antropólogos não dispõem de orientações suficientes no momento de fazerem suas opções éticas em pesquisas com interlocutores cujas atividades incluem atos de violência. (MACRAE; VIDAL, 2006) Procedimentos como a assinatura de atestados de consentimento se tornam surreais com pessoas procuradas pela polícia, por exemplo. Como a própria inserção no campo é negociada, os diálogos posteriores seriam consentidos por definição. (OLIVEIRA, 2004) Não faz sentido o consentimento para a autoincriminação de Dobem. Enfim, esta papelada para proteção aos seres humanos tem por objetivo mais a salvaguarda das instituições de pesquisa e menos os sujeitos pesquisados, em seus interesses e dignidade. (BOURGOIS; SCHONBERG, 2009)

Contribuir para a venda de produto roubado, certamente é crime e possui suas implicações legais e éticas, possivelmente não teria levado meu interlocutor ao local da venda de seu produto roubado caso tivesse todas as informações, primeiro de tratar-se de produto fruto de roubo e segundo de estarmos nos dirigindo à Praça da Sé, para lá, efetuar sua venda. A princípio estariamos apenas "dando um cavalo", ou seja, uma carona. Contudo, sem acompanhar os nativos, como cumprir o imperativo do ofício de antropólogo nos legado por Malinowski? 
Por outro lado, neste tipo de pesquisa, recomenda-se ao etnógrafo que de vez em quando deixe de lado máquina fotográfica, lápis e caderno e participe pessoalmente do que está acontecendo. Ele pode tomar parte nos jogos dos nativos, acompanhá-los em suas visitas e passeios, ou sentar-se com eles, ouvindo e participando das conversas [...] Esses mergulhos na vida nativa - que pratiquei frequentemente não apenas por amor a minha profissão, mas também porque precisava, como homem da companhia de seres humanos [...]. (MALINOWSKI, 1978, p. 31)

A companhia dos usuários de crack seguiu sendo, em todo período de trabalho de campo, a mais prazerosa e instigadora das interlocuções. Necessito estar com eles para a pesquisa de campo e desejo estar em sua presença pela oportunidade de discutir o tema de minha paixão intelectual atual - o uso coletivo na roda de crack. Com nenhum outro grupo, mesmo os acadêmicos, esta questão pôde ser tão bem compreendida, vivida e compartilhada. Sentarmos em sua companhia no cotidiano de suas atividades não nos pareceu coisa diferente de fumar com eles. Em uma roda de crack, fuma-se. Ou se faz um "corre", ou um "peão", se está ou não se está junto na "caminhada". ${ }^{34}$

No entanto, devemos tomar certo cuidado. Por tratar-se de ambiente relativamente próximo ao do pesquisador; por este possuir histórico de uso intensivo de drogas, o que poderia contribuir para obtenção da confiança necessária ao trabalho etnográfico baseado na qualidade das relações. Há sempre de se tomar precações para que a natureza da confiança e envolvimento pessoal nas relações de campo em excesso não enviese a pesquisa. (JOHNSON, 1983)

Para um debate sobre a oposição entre "experimentar lá" e "escrever aqui", outra questão se coloca: a de pensar a relação

34 "Corre", "peão" e "caminhada" são termos nativos fundamentais para se iniciar o trânsito na cultura do crack. São três dimensões do movimento. 
entre pesquisador e seus interlocutores como dispositivo central de construção do saber antropológico. Juntos, na "caminhada", nos tornamos "parças", e esta relação pode ter papel fundamental na construção do tipo de conhecimento antropológico que nos interessa. (ENGLUND; LEACH, 2000) Daquele que toma as atitudes de observador e observado como análogas, ou "reversas". (WAGNER, 1981) Pois afinal, o estudo da cultura, cultura é. Como na improvisação do jazz, todo ser humano inventa cultura. O ofício antropológico propõe a criação de uma narrativa a respeito do outro, que parte das relações construídas no campo. Quando se adentra na intimidade cultural nativa (HERZFELD, 1997), certos relacionamentos passam a ser constantemente negociados. O tipo e profundidade das informações que daí irá surgir dependem e mesmo provém, grandemente, da qualidade destas relações. Antes de se obter informações a respeito das relações entre nossos interlocutores, devemos construir relações com eles. (STRATHERN, 1999) É um movimento que vai das relações com eles para o saber sobre as relações entre eles.

Para a construção desse saber, ou para a produção de um discurso que se pretende simétrico (LATOUR, 1994), que não se coloque como superior ao discurso nativo. Quanto mais intensamente afetados formos pelas relações proporcionadas pelo campo e, principalmente, pelas mesmas forças que atuam sobre eles, naquilo que para nós é o campo e que para eles é a vida. Isto permite ao etnógrafo sentir, não a sensação no outro, mas em si, as consequências de estar na mesma posição do interlocutor. (FAVRET-SAADA, 2005) A partir deste encontro, a escrita etnográfica pode se dar do modo mais profícuo. Quando aceitamos participar ativamente da roda de crack, era atrás disto que estávamos. Não significa assumir o ponto de vista do usuário de crack, ou buscar algo oculto por trás de suas práticas, mas construir um ponto de vista a partir do ponto de 
vista da nossa relação com o ponto de vista nativo. (VIVEIROS DE CASTRO, 2002)

Malinowski (1978) fornecia tabaco aos trobriandeses em troca de permissão deles às investidas do pesquisador sobre os assuntos tribais, assim como a fim de estar em posição de fazer boas questões e obter boas respostas. Gerald Berreman (1962), em sua pesquisa no norte da Índia, valeu-se dos serviços de um intérprete abstêmio de álcool e não comedor de carne, três meses se passaram e seu intérprete adoeceu sendo substituído por um muçulmano bebedor de álcool e comedor de carne. Apenas então, Berreman pôde saber do costume de se realizarem festas intercastas com bebidas alcoólicas e carne. O acesso a informações dos mais variados tipos só foi aberto após os moradores saberem da ocorrência de ocasiões de uso da bebida alcoólica local na casa de Berreman.

Os limites da atuação do antropólogo em campo foram colocados em questão na descrição acima. "Dar um cavalo"35 ao Dobem, ele passou posteriormente e de modo insistente a me pedir para guiar o carro e tive de encontrar formas de recusar sem ofendê-lo, da mesma forma como me neguei a dirigir pela contramão e guiar do modo espetacular desejado por ele.

\section{Os interlocutores Cláudia e Salomão no morrinho}

Como nos vestimos de maneira diferenciada do comum dos frequentadores da "biqueira", mas principalmente através de Newman foi possivel adquirir muitas pedras, isto deu uma forte impressão de que a nossa presença causava algum desequilíbrio no campo e em três oportunidades, este fato pareceu bem claro. Na primeira delas, Dobem estava "na responsa", trabalhando, vendia certa quantidade de pedras e retornava à "biqueira" para buscar outro montante; este era novamente vendido. Sua respiração ofegante parecia haver se tornado

35 "Dar um cavalo" significa transportar alguém para algum lugar. 
parte de sua identidade, acompanhada pela tosse constante. Ofegante pela correria que compreendia, na prática, a travessia de dez pistas em avenida movimentada - ligações das regiões leste e oeste da cidade. Dobem vendia enquanto usava e vice-versa. Pelo nosso lado do barraco, ele adentrou certa feita com uma sacola branca contendo duas caixas de celular fechadas. O negócio foi rapidamente realizado para certo espanto geral, inclusive meu que teria de desembolsar "emprestado" o dinheiro para Newman. Quando saímos a campo, sabemos que é sobre o antropólogo que recaem parte dos gastos. Em meio a breve negociação, Zezé protestou que não queria "treta" em seu barraco, pois Dobem havia realizado a venda para Newman e entrara de modo intempestivo, ofegante, arfando e transmitindo um senso de urgência no conjunto de suas atitudes. Newman havia também adquirido dois "blocos". O protesto de Zezé gerou um conflito e fomos convidados por Dobem a dirigir-nos a outro barraco que providenciara logo após a discussão com Zezé. Dobem chegou a desdenhar de Zezé publicamente declarando não ser ele sequer malandro. Soubemos, mais tarde, da animosidade antiga entre os dois. Cerca de um mês depois, Zezé deixa a "biqueira" ao furtar $R \$ 40,00$ pertencentes a Russa.

A segunda oportunidade de desavença causada no campo, talvez devido a nossa presença, aconteceu enquanto esperávamos, sem a companhia de Newman (já nos dirigindo à "biqueira" sozinhos), a volta de um usuário chamado Salomão de outra "biqueira" próxima, a "29", com os "blocos" encomendados para ele. Neste momento, o "contenção", aparentemente por nos ver na companhia de Cláudia, usuária amiga de $\mathrm{Ne}$ wman, imagina o "fluxo" acontecendo. Ela procura explicar as circunstâncias, porém, o "contenção" recusa-se a ouvi-la e surge uma discussão ríspida entre ambos até a chegada breve de Salomão. Cláudia foi acusada de estar mentindo e de tentar esconder crack. 
Cláudia para Ygor - Eu falei pra você por um 'trago' aqui? Ygor - Nããão. É que ela tá me explicando como é que faz pra puxar.

'Contenção' para Ygor - Não brother, você não tem nada a ver, não. Você aqui é turista.

A terceira ocorrência foi no momento de "dar um cavalo" para Dobem até outra "biqueira da mesma firma", de onde vêm as pedras comercializadas no local da pesquisa. Ao nos ver deixando o local com Dobem, Cláudia bate no vidro do carro e me convida a juntar-me a ela quando de meu retorno. É repelida por Dobem; ela retruca dando a volta no veículo e batendo fortemente na janela ao lado dele de modo ameaçador. Em ocasião anterior, a ser descrita em seguida, o usuário Salomão preocupa-se em levar-me sem muita demora de volta à "biqueira", tendo em mente um compromisso firmado por mim com Dobem, de conduzi-lo à região da Avenida Paulista. Compromisso acertado em frente a Salomão, mas não cumprido posteriormente.

Em nossa primeira incursão à "biqueira" a céu aberto sem a companhia de Newman somos recebidos por Salomão, ele fazia a "contenção" no momento, mas poderíamos considerar também sua estada ali de modo oportunista, aguardando a chegada de alguém com quem pudesse fumar. Em outra visita, a pessoa disposta na mesma esquina limitou-se a encaminhar-me ao local onde deveria, teoricamente, realizar a compra dos "blocos".

Certamente, envolver-se nas trocas levanta um problema ético. A troca, como elemento fundamental de inclusão e exclusão de indivíduos na comunidade de usuários de drogas foi amplamente debatida em pesquisa com consumidores de heroína nos Estados Unidos. Os antropólogos detectaram que a comunidade de usuários se mantinha através de uma economia moral das trocas (BOURGOIS; SCHONBERG, 2009), esta economia os envolve em uma rede de relações mútuas e definem os limites da comunidade. Ou seja, faz parte quem troca. Não 
trocar é ser antissocial e arriscar-se a ser levado ao ostracismo. Os autores preocuparam-se em não comprar informações, ou tornarem-se patrões, mas não poderiam ficar alheios à forma corriqueira (troca de alimentos, dinheiro e drogas) de definir e expressar amizade, organizar hierarquias e excluir outsiders indesejáveis. Tiveram de aprender quando dar e quando negar, e concluem com a importante observação da inadequação das regras mais dogmáticas de pesquisa à realidade das ruas.

Roberto Cardoso de Oliveira (2004) ao criticar a Resolução n. ${ }^{\circ}$ 19/96 da Comissão de Ética em Pesquisa do Ministério da Saúde para regular os aspectos éticos das pesquisas com seres humanos discorda da extensão das preocupações com as pesquisas biomédicas para a antropologia, isso teria ignorado a realização por parte desta última, de pesquisas com observação participante entre populações ocultas, além de ignorar a diferença entre pesquisas em seres humanos (caso da área biomédica) e com seres humanos (situação da antropologia social e cultural). O paradigma da primeira é a relação com cobaias, da segunda, com interlocutores, neste caso, marcado pela negociação nos mais variados aspectos das interações ocasionadas pela incursão do antropólogo no campo, onde até o próprio objeto da pesquisa será negociado.

$\mathrm{Na}$ antropologia, os sujeitos da pesquisa são antes concebidos como pessoas, entidades socioculturais e a questão ética posta nesta relação de alteridade marcada pela diferença é o respeito por seus costumes, comportamentos e práticas. (CAROSO, 2004) É inevitável ao pesquisador de comportamento desviante, sujeito a sanções na forma da lei, infringir certas leis. (BECKER, 2008) Sabemos ser da Lei n. ${ }^{\circ} 11.343 / 06$ a penalização para quem "induzir, instigar ou auxiliar alguém ao uso indevido de drogas", em seu Artigo 33, parágrafo 2. Ficaria assim vedada, uma postura tolerante nas pesquisas com usuários de drogas em relação às suas práticas. Prossegue-se com 
as anotações do caderno de campo de setembro de 2013 sobre o ocorrido com Salomão e Cláudia.

Após a chegada de Salomão com as pedras, dirigimo-nos ao
outro lado da rua, até o barraco de Cláudia. Sentamo-nos
e outros usuários tentaram se aproximar e foram sendo
desencorajados pelo casal. Salomáo havia me passado
os blocos e os repasso à Cláudia. Logo percebem minha
inexperiência e falta de habilidade no uso do crack. Esta-
mos sob lonas e cobertores, acomodados sob um barraco
com um metro de altura no máximo. Salomão ressalta o
impacto agressivo do uso sobre os pedestres e do respeito
que, no meio dos usuários, propugna-se ter com as crian-
ças que, por ventura, possam valer-se daquele local como
passagem. Minha falta de habilidade, meu rosto gordo e
as vestimentas logo levam a suposições sobre meus pro-
pósitos reais. Salomão - Você é bem comedido. Você não fuma crack constantemente, né?

Ygor - Não, muito raramente.

Salomão - Esporádico, né?

Ygor - Esporádico. Sou um usuário recreativo. (Risos).

Salomão - Acho que você usa pra ter uma penetração nos lugares, assim também. Pra poder não ficar muito deslocado.

Ygor - Pra poder trocar ideia.

Salomão - Pra poder trocar ideia.

Logo sou convidado a seguir para outro lugar de uso mais isolado conhecido como Morrinho, trata-se do canteiro lateral da Avenida Radial Leste, a principal ligação da Zona Leste da cidade com as zonas Oeste e Sul. ${ }^{36}$ Para chegar ao ingreme local é preciso pendurar-se em uma grade de isolamento entre um viaduto e a Praça Almeida Júnior. Fica-se pendurado sobre a Avenida Radial Leste com suas dez pistas e carros em velocidade. A ida em relação ao retorno foi mais fácil, o uso do crack não melhora minhas habilidades motoras. O local é também propício ao encon-

36 Os "righteous dopefiends" estudados por Phillippe Bourgois e Jeff Schonberg usavam as laterais e baixos de viadutos das freeways californianas para utilizar heroína, álcool e outras drogas. (BOURGOIS; SCHONBERG, 2009) 
tro amoroso e sou alertado do fato pelo casal a me acompanhar.

Salomão - Isso aqui é um terreno acidentado [...] bastante pedra. A gente gosta de fumar ali, tem uma grade aqui no viaduto, tem o Morrinho. A gente gosta de ficar muito ali, tranquilo. Onde os caras levam as menininhas pra ficar de boa. Uma manta.

Cláudia - Uma companhia pra [...] (risos).

No caminho do Morrinho encontro um "vapor" da "biqueira", Dobem, e este me solicita uma carona à Avenida Paulista. Em uma próxima visita ao campo, ele faz o mesmo pedido e revela sua intenção de ir a esta importante via de São Paulo para realizar roubos. Por fim, acabei não o conduzindo a tal avenida. Como relatado, eu o havia levado, inadvertidamente, à Praça de Sé para efetuar a venda de um aparelho celular. Uma forma utilizada neste campo para tentar maior aproximação e quebra de desconfianças foi a alusão ao meu passado como usuário pesado de drogas. Repetimos, não sei se com sucesso, a mesma tática no Morrinho, o que pode ser visto nas anotações extraídas do caderno de campo de setembro de 2013.

\begin{abstract}
Após consumirmos a primeira pedra, Salomão faz menção ao desejo de ausentar-se para deixar eu e Cláudia a sós naquele local de encontros amorosos dos usuários da biqueira. $^{37}$

Salomão - Ó, eu vou me ausentar, pra deixar vocês aí.

Claudia - Por quê?

Ygor - Não. Fica aí, vamos fumar mais uma pedra aí.
\end{abstract}

37 Em uma próxima visita ao campo, ao dar uma carona ao "vapor", este me indaga se tenho interesse em namorar alguém na "biqueira". Apesar de minhas observações sobre meu estado civil de casado, Dobem insiste perguntando detalhes de meu gosto feminino e descrevendo algumas usuárias, em busca de conhecer minhas preferências no assunto. Ao ver minha insistência em negar algo possivelmente correspondente a um comportamento esperado no local - ter uma namorada - passa a desconfiar de minha sexualidade e a perguntar se realmente possuo interesse em mulheres. 
Claudia e Salomão permanecem divertindo-se em me instruir no uso. Fazem observações sobre a duração e intensidade dos efeitos, assim como da 'fissura'. Salomão diz: 'A brisa boa é quando dá um tuim'. Comentam de sua inadaptação a outras drogas e das possibilidades de se incrementar os efeitos do crack pelo uso da rapa. ${ }^{38}$ Espantam-se por eu nunca haver usado meu cachimbo e fazem questão de experimentá-lo. Salomão fala da importância da 'circunstância', da necessária sintonia entre os usuários para obter-se o efeito desejado do 'trago', ou brisa. É necessário 'pegar bem' com as pessoas na roda de crack. 'Porque a pedra, ela só [...] ela abre caminho' diz Salomão. Em sintonia com ambos foi, creio eu, meu estado naquele momento. Dai surgiu um imperativo ético. Neste momento, explico aos dois minha posição de pesquisador no campo. Salomão é soteropolitano e falamos um pouco sobre sua cidade. Ele me conta a respeito de outros pesquisadores que apareceram na biqueira com o intuito de filmar o local. Ele revela que pensava realmente que eu fosse jornalista, ou policial. Revelo minha preocupação em não ser visto desta maneira e ele me recomenda utilizar um boné. Posteriormente, quando chegarmos a combinar dele me acompanhar a outras biqueiras, ele irá recomendar-me que use roupas mais velhas para não chamar a atenção policial. ${ }^{39}$

A partir do texto retirado do caderno de campo e transcrito acima, vale a pena tecermos algumas considerações. Após alguns anos de pesquisa de campo, o sociólogo William Foote Whyte escreveu Sociedade de Esquina e nesta obra, descreve e analisa a organização social e a cultura dos jovens italo-americanos de um bairro apelidado por ele de Cornerville, no Boston's North End. Residiu e participou ativamente da vida social e política da comunidade italiana daquele bairro, chegando a fazer parte de clubes e sendo eleito para ocupar cargos de certa importância. Para ele, apenas dar uma volta com os rapazes de Cornerville não

38 "Rapa" é o nome dado ao produto da sublimação da fumaça oriunda da queima da pedra de crack depositado dentro do cachimbo.

39 Alguém burguesamente trajado acompanhado de usuário em seus trajes mais condizentes com a situação de rua, poderia atrair o zelo policial pela classe média. 
era suficiente para fazer uma pesquisa sobre a sociedade de esquina. Era necessário saber quais perguntas deveriam ser feitas e quando poderiam acontecer (WHYTE, 2005), mas em todo caso, se fazia necessário dar uma volta. Foi o que fizemos.

Sobre a "sintonia", ela é algo fundamental no uso do crack. Para poder usufruir os efeitos esperados não basta dar um "trago". Entre os usuários deve haver uma boa relação, uma espécie de harmonia nas atitudes, mas a "sintonia" é, certamente, também efeito da droga. A pedra só abre o "caminho", percorrê-lo na companhia de um "parça", com o casal, ou mesmo com um desconhecido recém-chegado à "biqueira" é uma possibilidade aberta pelo uso. Estarem todos em "sintonia" é um prazer em si mesmo e porque não o principal prazer possibilitado pela pedra e pelo ambiente? A satisfação proporcionada pela disposição de pessoas em roda, compartilhando uma mesma atividade e fumaça, dialogando, não é exatamente uma novidade nas possibilidades abertas pela vida social. Tudo maximizado por uma substância alteradora de humor, seu uso une e agrega, torna a presença do outro desejável para perfeita fruição das possibilidades abertas pelo crack, abridor de caminhos. Neste sentido, a "sintonia" é a "brisa".

A revelação do nosso papel naquela efêmera roda de crack formada por nós três no canteiro lateral da mais importante e movimentada ligação entre as regiões leste, sul e oeste da cidade, foi um efeito da "sintonia" do grupo e tornou possivel o desvendamento de minha condição de pesquisador, desde pouco antes intuída por Salomão. Assim como esta mesma "sintonia" tornou insuportável para mim a manutenção de qualquer segredo, ou disfarce. Para Galliher (1983) mesmo ao assumir a condição de nativo durante a pesquisa de campo, deixar clara nosso papel de pesquisador evitaria prática semelhante à espionagem. Vimos acima, como o imperativo da interlocução vem do campo, ele abre a possibilidade da clareza de intenções. Esta não é a priori, infelizmente há riscos não apenas para a 
maior ou menor probabilidade de se obter bons dados etnográficos, mas à própria integridade física do investigador e também dos interlocutores, como no caso de Newman.

A realização de um trabalho etnográfico significa a escolha por opções de comportamento e cumplicidade no campo (VAN MAANEN, 1983), escolha do que será ou não publicado, não havendo como não desagradar alguém por tratarem-se sempre de opções a serem feitas entre alternativas que agradam uns em detrimento de outros. Nossa escolha pela participação em práticas tornadas ilegais pela legislação proibicionista foi, em parte, facilitada por um histórico pessoal de vivência das mesmas práticas. Tanto quanto a escrita foi fortemente influenciada pelas escolhas feitas durante o trabalho etnográfico, isto também ocorreu na análise dos dados. Ao saber da pesquisa, Salomão e Dobem mostraram-se interessados em seu conteúdo. ${ }^{40}$ Há uma preocupação dos interlocutores com o conteúdo do trabalho, com a dimensão da amostra e sua significância.

Salomão - Mas você pode correr outros pontos, não pode? Ygor - Posso.

Salomão - Ó, tem a Barão.

Ygor - Se você puder me levar um dia?

Salomão - Ó, tem a Barão, pra cá tem o Gramado que também é uma 'biqueira' legal.

Claudia - 'biqueira tour'.

Ygor - 'biqueira tour', exatamente.

Salomão - Pra você conhecer, pegar outros tipos de depoimento.

40 Dobem, curioso sobre minhas intenções com o cachimbo - Esse aí vai observar né? Os alunos.

Ygor - Como é que é?

Dobem - Vai mostrar né? Você tá fazendo pesquisa.

Ygor - É, vou mostrar. Vou mostrar esse dele, que esse aqui é bem loco.

Dobem - A rapa, você vai mostrar?

Ygor - Então, preciso aprender como é que tira.

Washington - A rapa desse aqui é boa.

Ygor - Desse cachimbo? 
Ler a respeito da experiência etnográfica não é passar por ela, não é dar um "trago"nas margens quase inacessiveis do viaduto. O mundo a se entrar como leitor deste trabalho, não é a experiência direta da vida nas esquinas da sociedade, estando o autor engajado na interpretação desta, como reconstrução, inscrita no texto, assim, o texto produzido não pode determinar como seus leitores irão interpretá-lo. (ATKINSON, 1990) Contudo, tomamos o cuidado para não produzir nos leitores um efeito inverso ao pretendido, isto é, esforçamo-nos por apresentar nossos interlocutores em toda sua dignidade, como pessoas interessantes, inteligentes e plenas no domínio de sua vontade. Pretendemos contrapor-nos ao discurso midiático de "culpabilização das vítimas" (MACRAE, 2013, p. 7), mas sabemos também que, infelizmente, ao tomar contato com os dados colhidos no campo, pela leitura de uma etnografia, o leitor está livre para interpretá-los do modo mais negativo possivel e terminar a leitura mais convencido de seus preconceitos e igualmente engajado na produção da morte social dos usuários.

Marcel Mauss (1974) formulou o conceito de morte social ao tratar da "sugestão coletiva da ideia de morte" entre povos australianos e malaio-polinésios. São mortes socialmente provocadas por magia ou pecado, ambas capazes de romper a profunda ligação do sujeito com as "coisas sagradas" e provocar neles a crença do fim iminente. "A consciência é então inteiramente apoderada por ideias e sentimentos que são inteiramente de origem coletiva [...]" (MAUSS, 1974, p. 190) e os pensamentos mórbidos de encantamento ou culpa levam ao óbito. Creem os australianos sobre a morte, que se estas não são violentas serão certamente de origem mágica. A magia geralmente faz cometer o pecado e este leva à ruptura da comunhão com as potências sagradas. $\mathrm{O}$ indivíduo tem chance de sarar mediante cerimônia de exorcismo, um contra feitiço ou espírito protetor. Todo este conjunto de crenças e práticas possui a mesma ori- 
gem coletiva. Para o autor, a força física destes povos contrasta com sua fragilidade frente à ideia do encantamento, do pecado e da magia. No caso polinésio, a moralidade seria a maior causa de mortes, principalmente por pecado mortal. Magia e pecado atuam um em função do outro, ora magia provocando o pecado, ora o pecado possibilitando a eficácia da primeira. A consciência de estar enfeitiçado pode provocar a morte rápida por prostração ou por melancolia. Aí, o social encontra o biológico, não por vontade ou escolha pessoal, sequer por ideação involuntária, mas pelo medo provocado pela sugestão coletiva desorganizar toda a vida. "O indivíduo encantado, ou em estado de pecado mortal, perde todo controle sobre sua vida, toda escolha, toda independência, toda a sua personalidade". (MAUSS, 1974, p. 207)

Os usuários de crack também passam, em certa medida, por um processo de morte social. A suposta perda de domínio sobre a vontade, justificativa para medidas agressivas como a internação involuntária, dá-se mais por efeito de certo conjunto de crenças a respeito do uso do crack e destas crenças sobre as ações dos não usuários e menos por qualquer propriedade farmacoquímica associada à droga. Como observou certa vez um usuário a dialogar comigo, ambos sentados no meio da rua, durante uma festa junina na Cracolândia: "E o pessoal, aî? Devem pensar que a gente é lixo [...] Eles passam pela gente como se fôssemos lixo."

Também a mídia se encarrega de caracterizá-los como zumbis, o morto vivo propriamente dito. (BOES, 2011) É como se houvessem cometido suicídio ao valerem-se da "droga que mata", mas permanecessem ainda meio vivos, moribundos, na espera da morte certa. São definidos e desqualificados pelo uso de certa substância sem dominar sua produção, preço, qualidade, quantidade e disponibilidade. Tamanha alienação é precariamente compensada pela emergência da cultura da droga e de uma vida comunitária. A perda da vontade é imposta de fora 
para dentro e não o inverso. Não é o usuário sob efeito do crack sem domínio de seus desejos e atos, mas sim, o "nóia" socialmente construído e subsumido a um mercado e uma legislação alheia à sua vontade.

O pecado cometido de abrir mão da vida, de "sustentar o tráfico", de "ter de roubar para sustentar o vício" abre espaço para a maldição, a sentença de morte: “[...] e seus amigos os contemplam sem escutá-los, sem nada fazer, aceitando sua sorte sem aflição". (NEWMAN, 1882, p. 471) O estudo de Newman (1882) foi citado por Mauss em seu trabalho sobre a morte social, porém, ele esconde um dado importante constante do texto original. ${ }^{41}$ Aí, Newman logo acima e no mesmo parágrafo citado, descreve as prováveis causas para a morbidez por depressão entre os Maori da Nova Zelândia. Ela está na perda de seus campos agriculturáveis, de seus cemitérios, dos rios e lagos para pesca; da consciência de seu decréscimo populacional na época da colonização. Isto nos suscita pensar na concretude material desta morte social. Ela é também a retirada dos meios de reprodução da vida, do emprego, da casa, da vizinhança e do bairro. O usuário da Cracolândia foi, muitas vezes, expulso não apenas da residência familiar, mas também do bairro, da "biqueira" próxima ao seu local de moradia, onde possivelmente muitos deles iniciaram sua carreira no crack. Como observou certa vez nosso informante-chave Newman: "quem está na Cracolândia é porque não consegue frequentar 'biqueira' decente”. Os usuários não perderam o domínio sobre a vontade, eles a usam diariamente em suas "correrias", porém, lhes foram negados os meios de satisfação de sua necessidade de obter e usar a droga de uma forma diferenciada da impingida pelos não usuários, ${ }^{42}$ pelo mercado desregulamentado (tráfico) a par-

41 Disponível durante o período de realização desta pesquisa para consulta na internet em: http://rsnz.natlib.govt.nz/volume/rsnz_14/rsnz_ 14_00_ 006550.pdf.

42 Pelo menos publicamente. 
tir do Estado. O usuário fiel ao seu estilo de vida não perdeu o controle sobre sua existência, sua capacidade de fazer escolhas e sua independência, ele nunca às teve como usuário. Foi-lhe sempre vedado possuí-las, seja pelo mercado ou tráfico, seja pelo Estado, enfim, por toda máfia antidrogas. (BUCHER; OLIVEIRA, 1994) A proibição abre as portas da condenação, assim passou com a maconha e a população escrava recém liberta no Brasil. (ALVES, 1998) O morto-vivo, o zumbi, o abjeto (RUI, 2012), qualquer segmento desta maneira caracterizado acaba candidato a ser alvo de políticas de higienização, ou puramente repressivas. ${ }^{43}$

Depois de esclarecida minha identidade como antropólogo, o programa de pós-graduação do qual era oriundo, nosso orientador e mais algumas considerações sobre lembranças comuns do bairro de Ondina em Salvador, as desconfianças diminuem ainda mais e Salomão sugere a necessidade de conhecermos outras "biqueiras" e fumódromos para dar maior abrangência à pesquisa. Também me aconselha a não fumar e conversar com Claudia sobre sua determinação em não aproveitar-se da situação a ponto de me induzir ao uso e tirar daí vantagens. Isto poderia nos permitir pensar na visão dos usuários sobre eles mesmos e seus pares, em como passam a internalizar a visão negativa construída, principalmente, pela mídia sobre eles. Como a existência na rua vai formando, com exemplos retira-

43 O fim de escravidão abre espaço para toda uma estratégia de normalização da sociedade e será posta em prática no Brasil, por médicos, higienistas e sanitaristas. Foi desencadeado um verdadeiro processo de medicalização da sociedade brasileira, como uma intervenção social intensa, autoritária e sem fronteiras. Segundo Roberto Machado, para estes profissionais médicos, os inimigos do corpo social eram os "excessos e desvios", para combatê-los fazia-se necessário disciplinar a sociedade, incutindo valores e deste modo destruir os "vícios e perversões" que ameaçavam os centros urbanos. A medicina, portanto, não se caracterizou somente pela "promulgação de leis ou por uma ação lacunar fragmentária, de repressão aos abusos, mas exigiu a criação de uma nova tecnologia de poder capaz de controlar os indivíduos e as populações, tornando-os produtivos ao mesmo tempo que inofensivos." (MACHADO, 1978, p. 156) 
dos de histórias repetidamente contadas e experiências vividas, uma imagem do usuário ardiloso, repleto de conhecimento sobre como sobreviver na rua, a partir, de algumas estratégias com certo nivel de trapaça. Ao demonstrar sermos ético e correto com Salomão, ele aparentemente sentiu-se obrigado a agir de modo recíproco comigo. Sua única recomendação foi sobre meus trajes. Deveriam ser mais modestos a fim de não chamar a atenção da polícia sobre nós, eles poderiam resolver me proteger de Salomão. Michael Agar (1980) em sua pesquisa com usuários de heroína nova-iorquinos foi energicamente compelido por eles a adaptar-se ao seu modo de vida para não colocá-los em risco. Para estar com meus interlocutores é preciso não comprometê-los com a polícia, dominar alguns códigos, certas posturas e não ser descuidado, ou "vacilar" em meio a uma atividade ilegal. Philippe Bourgois (2003) comenta suas dificuldades de homem branco em El Barrio, região de Nova Iorque e local de sua pesquisa. Como era frequentemente abordado pela polícia por suspeita de ser um usuário em busca de drogas, ou simplesmente um otário perdido em local inapropriado a alguém de seu status, Bourgois em sua pesquisa com usuários de heroína, teve nos constrangimentos legais, sua preocupação mais imediata. A simples presença dos pesquisadores foi cogitada por ele como algo possivelmente perigoso aos usuários.

Contei com as possibilidades abertas pela presença de Newman no início de minha investigação, somadas à disposição em frequentar os locais de uso, os territórios psicotrópicos sob a fumaça constante, no beco, este espaço ao mesmo tempo, ponto de mercado e ponto de uso. (FERNANDES; PINTO, 2004) Newman viabilizou a presença no campo com chances de acompanhar práticas, e certamente, discursos e racionalizações provenientes de meus interlocutores, de certa forma mais próximos à condição de "parceiros". Da tensão inerente ao trabalho etnográfico, entre mais observar ou mais partici- 
par, se pode concluir que nesta pesquisa, caso o meu papel de observador se destacasse em relação ao de participante, teríamos de dispor de muito mais tempo para conseguir atingir a condição de "parceiro". Na pesquisa etnográfica da antropóloga Luana Silva Bastos Malheiro (2013) em região do centro velho de Salvador/BA, valeu-se de sua condição de redutora de danos para aproximar-se dos usuários, porém, demandou um período de oito meses de contato até poder presenciar as cenas de uso. O trabalho de Bruno Ramos Gomes e Rubens Adorno sobre as trajetórias de usuários de crack no centro de São Paulo também se valeu da condição de profissional atuante em redução de danos do primeiro, como modo de acessar o campo. (GOMES; ADORNO, 2011) Em sua pesquisa sobre uso de crack entre prostitutas da região da Luz, no centro de São Paulo, Selma Lima da Silva valeu-se da companhia de membros da Pastoral da Mulher Marginalizada da Arquidiocese de São Paulo e precisou vencer a resistência destes à pesquisa. (SILVA, 2000) Caso extremo foi uma pesquisa de doutoramento em antropologia social com o trabalho de campo integralmente mediado por programas de redução de danos. (RUI, 2012) A pesquisadora passou sete meses em negociações com o programa para visitar locais de uso na cidade de Campinas, no estado de São Paulo e não estava autorizada a fazê-lo sozinha. Também lhe foi vedado o uso de gravador e "algumas perguntas jamais puderam ser feitas”. (RUI, 2012, p. 35) Ficou totalmente restrita aos horários, contatos e trajetos das equipes de redutores. Era-lhe até proibido levantar os históricos de uso de drogas e chegou a ser diversas vezes repreendida por seu comportamento como "redutora". Mesmo nestas condições, ir para o campo sozinha sequer foi cogitado pela futura doutora em antropologia, apesar de afirmar ter destreza para circular nestes espaços por sua experiência pregressa como "educadora de rua". Os usuários são por ela considerados uma "população de dificil acesso" e a pesquisa sem estas "instituições legitimadas" seria para ela 
"quase inviável". ${ }^{44}$ Desta perspectiva, a autora pretendeu estudar o consumo abusivo realizado, segundo ela, por uma pequena parcela dos usuários e reconhece ter conseguido dados de qualidade apenas "razoável". ${ }^{45}$

Um trabalho etnográfico sobre uso de drogas injetáveis na região central de São Paulo, com interlocutores de classe média e outros provenientes do lumpesinato foi levado à frente por Osvaldo Fernandez, entre o final dos anos 1980 e início da década de 1990 do século passado. O estudo contempla práticas "pesadas" entre usuários socialmente distantes do antropólogo, observados nas cenas de uso. ${ }^{46}$ Este se assemelha mais ao tipo de pesquisa de campo sobre drogas, desenvolvida aqui.

\section{0 uso do gravador e câmera fotográfica levanta a questão da segurança do pesquisador e interlocutores}

Observamos diversas vezes a disposição dos usuários de crack, frequentadores de um mesmo local de uso e convivência, em comentar sobre os acontecimentos locais. Contudo, após ter

44 O inverso pode ser dito dos redutores de danos com quem ela diz compartilhar experiência educacional e gostos por viagens e profissionais.

45 A autora decidiu pela pesquisa com o tema do abuso do crack e não sobre o trabalho das equipes de redutores, um contraponto à pesquisa anterior da antropóloga sobre comunidades terapêuticas, após perceber o apelo do tema do uso do crack. Ou nas palavras dela: "Mais uma vez, enfatizo que o tema central, o consumo de crack, acabou se impondo durante o trabalho: não só porque tive mais contato com usuários dessa substância devido ao acompanhamento das atividades dos programas de redução de danos, mas também e, sobretudo, porque durante a pesquisa o crack acabou ganhando notoriedade inesperada". (RUI, 2012, p. 45)

46 A outra rede de entrevistados poderia ser conceituada como lumpesinato: sem remuneração/moradia fixa, com baixo grau de escolaridade, composta de dois travestis, dois presos, um homossexual e um bissexual. Os travestis trabalham na prostituição de rua, sendo um deles paciente de Aids na casa de apoio Brenda Lee. Na segunda rede de usuários percebemos, quando comparado com a rede de classe média, um número maior de pessoas com problemas com a lei, prisões e com mais casos de HIV/ Aids. Nessa última rede também há um número maior de indivíduos que recorreram a tratamentos psiquiátricos e psicológicos". (FERNANDEZ, 1997, p. 104) 
revelado nosso papel de pesquisador a Claudia e Salomão, por exemplo, e feito observações sobre a necessidade de manter-se sigilo sobre estarmos realizando uma pesquisa de cunho antropológico, percebemos, em nossa visita posterior ao campo, a indiscrição de nossos interlocutores. Na incursão seguinte ao campo, Dobem, ao conversar conosco em seu barraco, na presença de sua companheira e coordenadora da "biqueira", a Russa, veio questionar-me se eu seria algum jornalista, como quem já houvera sido informado de algo. Pergunta se estaria gravando a conversa. Importante observar que nas visitas anteriores ao campo havíamos feito uso de celular para proceder às gravações, porém, o aparelho, se visivel, causava imediata agitação entre os usuários e imediatamente tínhamos de colocá-lo em local não visível. Este tipo de aparelho é moeda de troca na "biqueira". Também seria impossivel o uso de caderneta de campo, estas ferramentas para registrar dados incomodam, assim como perguntar demais também pode "roubar a brisa" de alguém, fazê-lo (a) "perder o trago". Assim, adquiri outro tipo de gravador, mais discreto, na esperança de causar menor impacto visual nos ambientes de uso. Um pen drive mostrou-se muito apropriado, usei-o sempre após consulta aos presentes, porém, possivelmente por suas dimensões reduzidas causava menor desconforto aos usuários de crack e logo era esquecido.

$\mathrm{O}$ certo é restringir sua utilização à concordância dos interlocutores e após o esclarecimento sobre nosso papel de pesquisador. Outro procedimento se assemelharia a espionagem, como afirmado acima.

Porém, nada neste campo é simples. Cheguei a presenciar fatos muito comprometedores à segurança, tanto minha, quanto de meus interlocutores. Como por exemplo, o "resumo da biqueira". Situação tensa de contagem do dinheiro e acerto de contas entre a Russa, os "vapores" e um responsável da "Estudantes", como eles chamavam a "biqueira" localizada na rua dos Estudantes (São Paulo/SP), a "biqueira" provedora dos 
Jamais fomos zumbis

"blocos" comercializados na "biqueira"com fumódromo por eu frequentada. Ao chegar para dar início a contagem das notas e realização das contas, o enviado da "Estudantes" me encarou de modo desconfiado por alguns segundos, com seu rosto a uma distância de um palmo aproximadamente do meu. Com a intervenção de Newman, ele se acalmou.

\section{Prejuízos à saúde e convivência familiar}

Chegamos a experimentar crack nos anos 1990, em um contexto de esgotamento das fontes fornecedoras de cocaina em pó, após certa hora da madrugada. Não pareceu fazer nenhum efeito digno de nota e a experiência não se repetiu. Nosso abandono do uso do álcool acompanhado de cocaína deu-se após período de internação em clínica de recuperação e frequência a reuniões dos Narcóticos Anônimos. Mais de 13 anos depois, novo contato com a substância. Qual o risco de tornar-se usuário pesado novamente? Dificil dizer. Há algo diferente no atual uso, significativo o suficiente para nos permitir ter esperanças de resultado diverso do uso anterior? Aparentemente, sim. O propósito de uso nos parece a maior diferença. Há o propósito claro em estar com eles e coletar dados; fazer uma etnografia, produzir uma tese de doutoramento em antropologia social, base para o início de uma carreira profissional como antropólogo, professor de antropologia, pesquisador.

Além de ter sido "adicto em recuperação" 47 sou asmático em tratamento. As incursões ao campo, respirar a fumaça, tragar, levaram a muito significativa piora dos sintomas. Iniciei tratamento ainda sem maiores resultados e uma série de medidas profiláticas no ambiente doméstico. Até onde prosseguir? "Não faça nada com que não possa conviver, profissionalmente e pessoalmente" (BERNARD, 2008, p. 376), este conselho dado

47 Termo usado pelos Narcóticos Anônimos àqueles em permanente busca por recuperar-se da compulsão e obsessão pelo uso de drogas. 
ao comportamento sexual no campo poderia servir também a outros limites do corpo do etnógrafo.

Do meu corpo, ao corpo dos outros e à convivência familiar. Fazer campo junto à população tão estigmatizada e em ambiente repleto de representações negativas construídas pela mídia constitui desafio ao convivio familiar. Na prática, é retornar ao lar, rever esposa e filha após estar sentado sobre chão coberto de urina, em meio a ratos, na companhia de traficantes e pessoas que realizam pequenos roubos. Ir dormir depois de vivenciar alguém lhe mostrar uma faca e, principalmente, chegar em casa com os olhos "esbugalhados" pela inalação da fumaça, ou pelo "trago". Isto tudo poderia ter tido maiores consequências para a minha vida conjugal e familiar, como foi para Bourgois após o final de sua pesquisa em El Barrio, que coincide com o fim de seu casamento. (BOURGOIS, 2006)

O problema ético insolúvel deste tipo de abordagem na opinião de Zinberg (1984), ao tratar em seu clássico Drug, set and setting do uso controlado de substâncias psicoativas como a heroína, é a possibilidade de nossas considerações levarem alguém a usar a droga e vir a ter problemas posteriores, esta preocupação parece caber de certa forma nesta pesquisa. ${ }^{48}$ Ele reconhece o modo como sua pesquisa acaba sendo posicionada no debate público a respeito das drogas e o problema ético. $\mathrm{Na}$ mídia e até em ambientes profissionais e por que não dizer acadêmicos também, o show precisa ser "balanceado", um entrevistado, ou palestrante pró-drogas e outro antidrogas. Estes, posicionados pela proibição e abstinência; qualquer oposição ao proibicionismo é percebida como pró-drogas. Mas, acima de tudo, existia um problema ético para Zinberg: declarar que algumas pessoas são capazes de controlar seu uso de heroína. Pois, é possivel que esta informação pudesse levar algum indi-

48 Para Zinberg, demonstrar o uso controlado, além de combater estereótipos, serviria à construção e reforço de outras possibilidades de uso, além do pesado. 
víduo a usar a droga, sem estar preparado devidamente e em condições de lidar com isso. ${ }^{49}$ Não tratamos especificamente de uso controlado de crack, como fez Zinberg com a heroína, nossa pesquisa busca, contudo, um ponto de vista fora dos estereótipos. Os usuários não são zumbis, são pessoas interessantes, inteligentes e devem ser respeitadas em sua opção de estilo de vida, este é o meu posicionamento. A objetividade vem do respeito ao bom método de coleta e análise de dados. O quanto isto poderia encorajar outros a fumar crack? Esta pergunta não tem resposta. Resta-nos apostar, como Zinberg, no reforço a padrões de quem usa sem se deixar usar pela droga, como é característico ouvir no discurso nativo.

49 Quando se verificou que o uso controlado era praticado por diversos usuários, percebeu-se que a descoberta tinha de vir ao conhecimento público, este deveria ser alertado do fato de o uso ocasional de heroína ser também um padrão estável, tanto quanto o abusivo. 


\section{A RODA DE CRACK: CACHIMBO, BLOCO E USUÁRIO NA REDE SOCIAL}

A partir dos dados de pesquisa participante coletados entre usuários de crack da região central da cidade de São Paulo, pretende-se analisar como o uso do crack proporcionou a criação de uma rica parafernália, composta por ferramentas e utensilios dos mais variados, para a obtenção do melhor "trago" possivel. Ele também impulsionou o desenvolvimento de uma tecnologia do acobertamento com materiais disponiveis no ambiente urbano, utilizados para as necessidades próprias do contexto delicado do proibicionismo. Estes artefatos relacionam-se com os padrões de consumo da droga e rituais dos usuários ao serem trocados, compartilhados, vendidos, desmontados e refeitos ao sabor das necessidades e possibilidades dos craqueiros. Os artefatos ainda se prestam a prevenir danos, compor e demonstrar adesão a certos tipos identitários e corporalidades, assim, as estratégias de redução de danos acabam confrontando-se com estas práticas nas cenas de uso.

Cracolândia é o nome dado a muitas cenas de uso, o termo é usado em diferentes cidades do país, mas teve sua origem em São Paulo há mais de uma década e corresponde atualmente, à região próxima à Estação Júlio Prestes, no bairro da Luz. Partiremos do cachimbo para chegar à Cracolândia, e nesta caminhada teremos a oportunidade de dar uma breve mirada sobre alguns dos objetos produzidos pelo gênio craqueiro. Estes artefatos não-humanos possuem agência própria na rede social e podem ser acompanhados na prática. No interior das ocasiões em que são trocados, compartilhados, vendidos, desmontados e refeitos em sua mediação com o corpo.

Os objetos produzidos pelo gênio craqueiro serão contextualizados em práticas e representações produzidas no intercâmbio das coisas com pessoas em interação. Trata-se de cor- 
pos agenciando objetos e vice-versa em uma rede cuja tessitura é capaz de provocar constantes transformações.

\section{Maquinários e o cachimbo}

"Maquinário" é a categoria nativa para designar a parafernália utilizada no consumo do "bloco", ou pedra de crack. O cachimbo é o principal artefato deste conjunto, um mediador por excelência e a maior realização artesanal do gênio craqueiro. ${ }^{50} \mathrm{Na}$ web page da Confraria dos Amigos do Cachimbo, a descrição do ato de fumar assim aparece: "Fumar cachimbo é adaptar um ritual ocioso de descontração e prazer, que requer atenção, destreza e conhecimento. Talvez seja esta a razão que leva a generalidade das pessoas associe [sic] o cachimbo a pessoas nobres e profissionais". (CASTRO) Veremos como o cachimbo de fumar crack, ou "boris" também faz jus a estas observações, principalmente com respeito à atenção, destreza e conhecimento. Então, vejamos.

Figura 2 - Cachimbo de tabaco

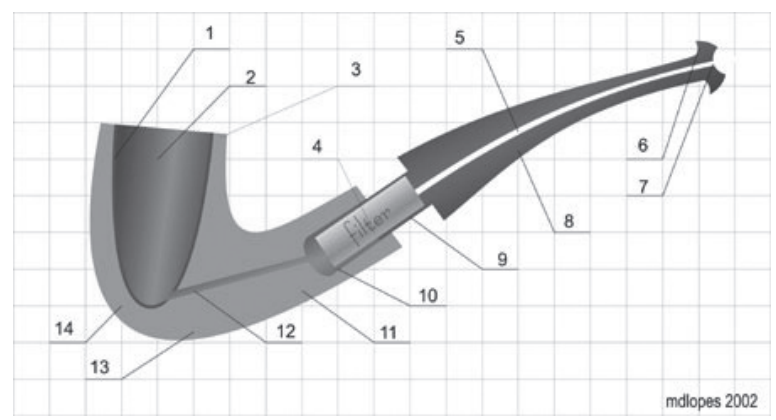

Fonte: http://www.amigosdocachimbo.com.br/artigos/art_cachimbo_fumar.htm

50 Por si só o cachimbo pode ser considerado um importante agente na fruição da pedra de crack: "[...] eu sinto diferença porque se eu fumar a pedra no cachimbo o tuim dela é mais forte do que na lata [...] na minha concepção a adrenalina no coração fica mais forte [...] aquela sensação de medo e da paranoia fica muito mais louca do que fumar ela (pedra) na lata. O cachimbo em si, por causa do caninho, a sensação é mais louca mesmo [...]". (OLIVEIRA, 2007, p. 101) 
Quadro 1 - Partes constitutivas do cachimbo

\begin{tabular}{|r|l|r|l|}
\hline 1. & "Bolo" & . & Haste \\
\hline 2. & Câmara do fornilho & Encaixe da haste \\
\hline 3. & Topo & 11. & Câmara de condensados \\
\hline 4. & Filtro & 12. & Canaço do ar do fornilho - haste \\
\hline 5. & Canal de ar da haste & 13. & Base \\
\hline 6. & Lábios da boquilha & 14. & Fornilho \\
\hline 7. & Boquilha & & \\
\hline
\end{tabular}

Fonte: http://www.amigosdocachimbo.com.br/artigos/art_cachimbo_fumar.htm

O diagrama acima e a tabela com as partes constitutivas do cachimbo feito para se fumar tabaco nos permitirá comparar este, com o "boris" ou cachimbo de crack e possibilitará sua análise a partir das partes constitutivas. O crack pode ser fumado de diversas maneiras, em latas dobradas e perfuradas, em copos de água mineral descartáveis sobre furo na tampa de alumínio, em copos de Yakult com o mesmo furo na tampa e um "caninho". Em cotovelos de tubulação de PVC, em lâmpadas, narguilés e certamente outras materialidades desenvolvidas a partir de experimentações desestabilizadoras. Porém, em São Paulo, o cachimbo é o instrumento mais utilizado, e fumar em cachimbo não é uma invenção dos craqueiros, mas costume muito difundido desde o consumo do "pito de pango", ou maconha, em maricas. (ALVES, 1998) Assim, utilizaremos o cachimbo curvo de fumar tabaco para comparar, em seus elementos constitutivos e práticas de manuseio, com o cachimbo mais comum encontrado por nós dedicado ao uso do crack. Esta comparação irá mostrar continuidades entre as práticas e mesmo entre as representações sobre este costume e nos fornecerá alguns parâmetros para conhecermos de que matéria o social está sendo feito. (CALLON, 2008) O cachimbo ou "boris" é, na maioria das vezes, arranjado todo em metal. A haste e seu encaixe costumam ser uma mesma peça, o "caninho". O encaixe se adapta comumente de modo direto ao fornilho, 
sem a necessidade de um pescoço que sirva de ligação entre os dois. Isto proporciona a passagem direta da fumaça que se pretende sorver, do fornilho à haste. O "boris" não costuma ser curvo, mas direito, termo usado pelos usuários de tabaco para referirem-se aos cachimbos retos, aqueles no qual o conjunto da haste forma um ângulo reto com o fornilho. Isto facilita a retirada dos restos de tabaco e saliva que possam impregnar seu interior. O cachimbo de fumar tabaco existe previamente ao de consumir crack, porém, é possivel que sempre estivesse presente como ideia (LAW, 1992) na rede social que inclui todos os materiais relacionados ao uso. Em um processo dinâmico de estabilizações e desestabilizações na relação entre estes objetos e os usuários, o copo de água mineral ${ }^{51}$ foi deixado de lado e o "caninho" acrescentado. No entanto, será na "rapa" que poderemos encontrar o agenciamento capaz de promover o processo de mutação. (LATOUR, 2012)

Figura 3 - Cachimbo com peça de fogão

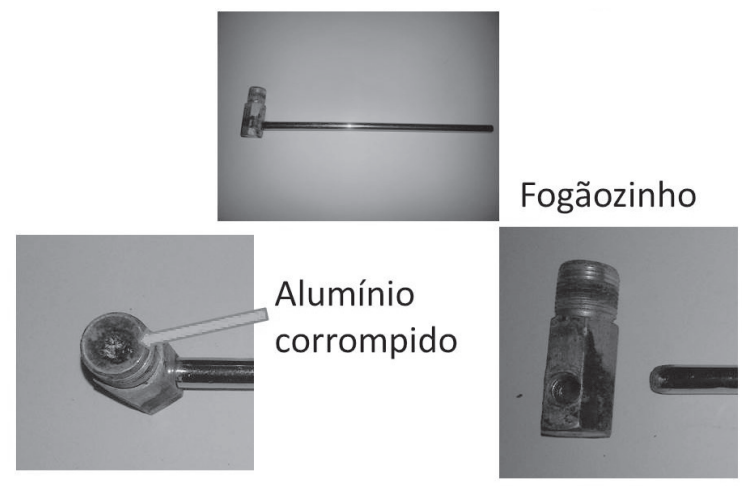

Fonte: Coleção pessoal do autor.

51 Na cidade do Rio de Janeiro, o copo de água descartável ainda é largamente utilizado. 
Para os consumidores de tabaco, a borra ou resíduo aderente às paredes da câmara e canal do fornilho, assim como ao canal da haste, é algo a ser retirado para evitar-se o entupimento do sistema, depois descartado. Para os usuários de crack, a "rapa" é valiosa, unanimemente tida como de poder superior ao "bloco" (pedra de crack). Os lábios da boquilha são do mesmo material da haste, muitas vezes metálico, isto leva a seu grande aquecimento após o contato reiterado da chama sob a base do fornilho, o que ocorre caso se deseje "atochar", ou "tochar" o cachimbo. Dá-se esse nome ao modo de consumir a "rapa" sem retirá-la, mas pelo aquecimento do "fogãozinho" ou fornilho e do "caninho". Abaixo, podemos visualizar a "rapa" em um raríssimo cachimbo de lâmpada. ${ }^{52}$

Figura 4 - Cachimbo de lâmpada

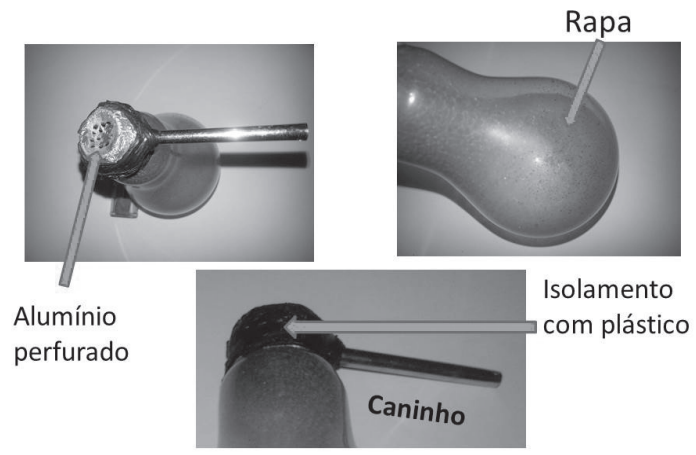

Fonte: Coleção pessoal do autor.

A queima da pedra é feita, não no interior do fornilho, como no consumo de tabaco, mas, em uma inovação introduzida sobre a tampa da câmara do fornilho tradicional, o alumínio. Ele

52 Ao referir-se às dificuldades do trabalho de redução de danos na Cracolândia uma autora descreve erroneamente a rapa como cinzas, assim como, o ato de "tochar" é confundido com a mesma "rapa". "Por fim e o que parece ser bem dificil, ainda aconselham os usuários a não fumarem as cinzas que ficam no cachimbo, a chamada 'bôrra' ou 'tocha”. (RUI, 2012, p. 88) 
é geralmente proveniente de tampa de copo de água descartável e posteriormente perfurado. ${ }^{53}$ Pelos depoimentos, o início do consumo do crack na cidade deu-se sobre o aluminio perfurado de copos de água descartáveis, assim, podemos afirmar de modo sintético que o copo tornou-se "fogãozinho", o alumínio perfurado foi mantido e acrescentou-se uma haste, ou "caninho". ${ }^{54}$ Neste caso, o usuário ou os usuários que fumassem uma quantidade razoável de pedras, dez por exemplo, poderiam retirar alguma "rapa" da tampa de alumínio do copo e se usassem água em seu fundo, a "rapa" boiaria sobre ela, sendo retirada em um processo dificil e pouco eficiente. A "rapa" e o desejo de obtê-la desestabilizou o conjunto copo/cinza/alumínio na prática do uso e até hoje, juntamente com o "trago" e os outros materiais presentes na rede sociotécnica (CALLON, 2008) do crack, continua a provocar transformações.

Figura 5 - Crack pronto para ser trabalhado

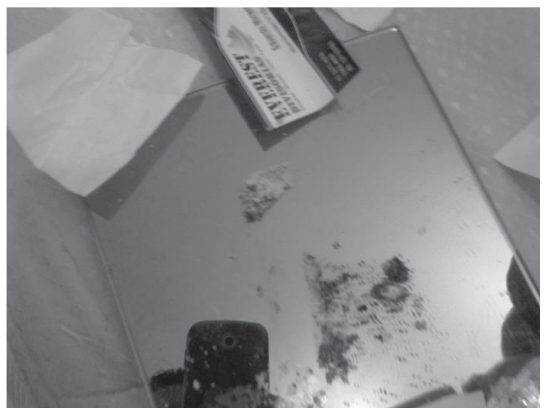

Fonte: Coleção pessoal do autor.

53 O mesmo copo descartável poderia ainda ser utilizado para o consumo do crack, mas seu uso praticamente desapareceu em São Paulo. De um para o outro, podemos sentir uma transformação ativamente manipulada para propósitos específicos. (LATOUR, 2001)

54 O mesmo é válido para a embalagem de Yakult, nela se fumava o crack sobre o alumínio original perfurado com o acréscimo de cinzas para evitar o escoamento do crack derretido, em sua combustão, para dentro da embalagem. O "caninho" já era usado neste sistema, mais próximo do cachimbo atual que a lata e o copo. 
Após se fumar uma quantidade de crack, a cinza utilizada já não serve mais para novo "trago" e deve ser substituída por cinza nova. O cigarro, desta forma, é presença indispensável nas rodas de pedra e suprimentos constantes são muito bem recebidos. Mas eles podem ser muito pouco fumados e muitos usuários de crack são abstêmios de tabaco. Um cigarro pode ser aceso e, depois de comedida fumada, muitas vezes sem tragar, deixado queimar em posição vertical até que todo o fumo seja transformado na desejada cinza. O uso do crack provoca um deslocamento nos objetivos (LATOUR, 2000) tanto da cinza, que é descartada pelo fumante, mas não pelo usuário, quanto do cigarro deixado queimar solitariamente e de sua fumaça. Ela terá de contentar-se em se espalhar pelo ambiente adentrando aos pulmões pela inspiração e não pela tragada. Esta mesma cinza, após a queima juntamente com o crack apresentado na forma de pedra ou pó, torna-se esbranquiçada e esse aspecto esbranquiçado, após o sorvimento da tragada pelo usuário, é sinal de destreza na prática de fumar. Os capazes de fumar com habilidade deverão ser também competentes em deixar a cinza, a mais branca possivel sobre o papel de alumínio, por vezes levemente côncavo a fazer às vezes de fornilho, para não passarem por "frangos", ou seja, neófitos inábeis. A cinza branca indica queima total da pedra lá colocada, destreza e ausência de desperdício. O "frango" em uma roda de crack pode ver-se na situação de ser, além de alvo de chacota, o mais solicitado a "fortalecer" ${ }^{55}$ outros participantes. Segundo interlocutores, pode, em casos extremos, ou em rodas com desconhecidos e/ou em "biqueiras" afastadas de sua "área", ${ }^{56}$ ser roubado e até vítima de sequestro relâmpago, caso aparente ter conta em banco e possuir cartão de saque. Assim sendo, como quase todas as nossas relações são mediadas através de obje-

55 "Fortalecer" neste contexto significa o ato de fornecer crack a alguém como um grande favor.

56 Local de moradia ou de consumo regular de crack, onde se é conhecido. 
tos (LAW, 1992), a aparência da cinza após a queima da pedra possui agência como signo mediador do prestígio do usuário na roda de crack.

Figura 6 - Cachimbo de curvinha com porca

Parte inferior de

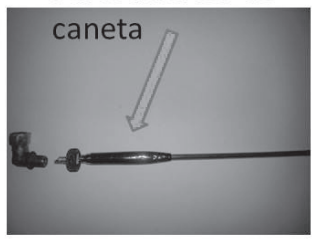

Alumínio perfurado
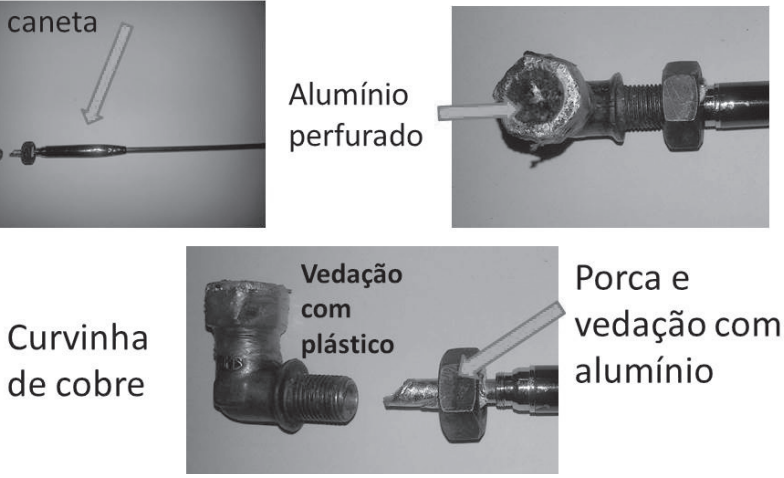

Fonte: coleção pessoal do autor.

O cachimbo acima pode ser considerado o estado da arte em termos de "boris". Destacam-se o "caninho" e o fornilho/ "fogãozinho" do tipo "curvinha", muito valorizado entre os usuários devido ao cobre utilizado em sua fabricação, capaz de produzir "rapa" branca ${ }^{57}$ e não preta é considerada de menor qualidade em comparação à primeira. Possui porca rosqueada ao fornilho e também a uma caneta por onde passa o "caninho". Juntamente com um papel alumínio colocado entre o "caninho" e a parte interna do fornilho, promove ampla vedação do

57 Ao entrar em contato com um usuário de posse de cachimbo "feito de cobre" em sua pesquisa de campo, Rui (2012, p. 186) ouviu uma explicação de um redutor de danos sobre as vantagens do cobre "Os redutores disseram-lhe que o cobre é um dos melhores materiais para a confecção do cachimbo: não provoca intoxicação como o alumínio; aguenta o calor, diferentemente do plástico; não quebra como o vidro; mas tem a desvantagem de ser mais caro." Porém, não parecem ter obtido do usuário informações sobre as vantagens da "rapa" branca. 
sistema e um "trago" muito agradável. "Caninhos" mais longos permitem o consumo de uma fumaça mais fria e o termo usado para esta prática é "buscar longe". Após uma tragada, diferentemente do cachimbo para tabaco, no "boris", o fornilho não serve para colocar fumo, cinza ou pedra, mas como câmara de gás e lá, a desejada fumaça oriunda da queima da pedra sobre a cinza se concentra após o "trago". O objetivo do "chimbó", outro nome para cachimbo é permitir a rápida e total queima da pedra para produção da fumaça a ser absorvida após cumprir seu trajeto iniciado no fornilho, se estendendo pela haste até a boquilha, passando pela cavidade bucal, faringe, laringe, até atingir a traqueia e se dividir entre os brônquios direito e esquerdo para através destes chegar aos bronquíolos e à corrente sanguínea. Segundo alguns, a confecção destes artefatos, com sua grande riqueza de detalhes é preferencialmente realizada sob o efeito da "brisa" do crack, ela aumentaria, de acordo com as palavras de um ex-usuário, a sensibilidade artística do craqueiro/artesão.

No "trago", a fumaça é absorvida no pulmão e pode posteriormente ser eliminada tanto pela boca, o mais comum, quanto pelo nariz. Enfim, deseja-se obter fumaça, é ela o bem valorizado no momento do "trago". Após este, a "boquilha" é comumente tampada para evitar-se a perda da fumaça que não pôde ser tragada apesar do esforço feito pelo diafragma e pulmões. $\mathrm{O}$ topo da câmara do fornilho/ "fogãozinho" também se encontra coberto pela cinza requeimada no processo de combustão da pedra. A fumaça fica presa dentro do sistema que compõe o "chimbó" de fumar pedra. É possivel sorver com relativa tranquilidade a fumaça aspirada, pode-se respirá-la e, se o usuário quiser ou tiver necessidade, conversar, pedir algo, beber água ou alguma bebida alcoólica de sua preferência, enquanto obstrui firmemente com o polegar a boquilha até um derradeiro "trago", colocando o isqueiro aceso novamente sobre o topo do fornilho. Após esta repetição, a cinza poderá ser retirada e a 
boquilha liberada. Se não houver nenhum reparo a fazer no "boris" e disponibilidade de pedra, cinza e isqueiro, o processo poderá ser reiniciado quando for conveniente, minimizando-se o desperdício. Assim, o corpo do usuário aprende a registrar o mundo acrescido pela materialidade da pedra de crack. Este corpo se dispõe a ser afetado em um processo pedagógico aberto a algumas imprevisibilidades e alternativas (LATOUR, 2008), como veremos a seguir.

Figura 7 - Segurando a fumaça

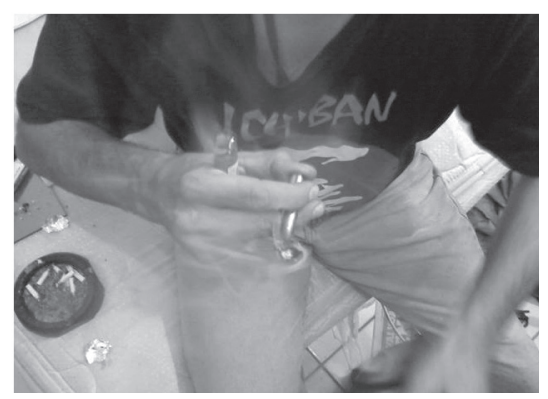

Fonte: Coleção pessoal do autor.

No "boris" ou "chimbó", o material depositado no fornilho e no "caninho", a "rapa", corresponde à parcela do montante que se intenciona consumir. ${ }^{58}$ Não esqueçamos que a superfície do "fogãozinho" não tem contato direto com a pedra e tampouco com a cinza queimada em outro fornilho feito sobre o alumínio no topo da câmara. Assim sendo, o "fogãozinho" é

58 A sublimação da fumaça não ocorre em uma câmara separada, como no caso do cachimbo de tabaco, ou seja, entre o pescoço do fornilho e o encaixe da haste, dando-se por toda extensão do "boris". Isto faz o material se depositar por toda a haste, além do "bolo" depositado no fornilho. No caso dos cachimbos de madeira utilizados no consumo de tabaco, este bolo deve ser mantido até a espessura de 1,5 mm. Caso cresça demais, reduzirá a capacidade do fornilho. Porém, quando retirado, não deverá sê-lo em sua totalidade, já que a presença do "bolo" é fundamental no uso de cachimbos com fornilhos de madeira. 
integralmente raspado para a retirada da borra depositada. Esta é novamente fumada. Pode ser constantemente misturada à cinza que vai se obtendo na queima de cigarros em um processo de esmagamento da borra colocada em meio a cinza sobre uma superficie de apoio. Um cartão de visitas ou carta de baralho geralmente presta-se a essa tarefa, com ele é misturada a borra retirada da haste e "fogãozinho", geralmente após o desmonte do conjunto. Tudo é amassado, novamente espalhado e amassado outra vez até que atinja a aparência desejada. Com o cartão levemente arqueado no sentido do lado mais longo, a mistura é colocada com o apoio dos dedos indicador e polegar para evitar desperdício de material sobre o fornilho do "chimbó", estando assim, apto a ser fumado ou entregue a outro integrante da roda de crack.

Figura 8 - Preparo do crack para uso

Colocando a cinza

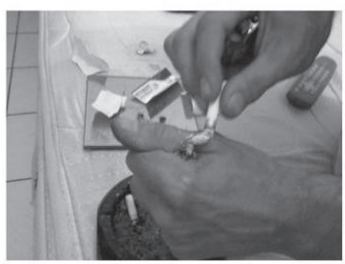

Trago sobre cinza

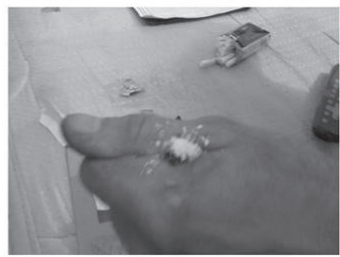

Bloco/Trago

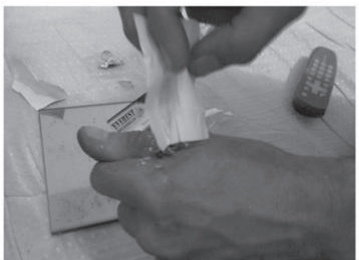

Pronto para uso

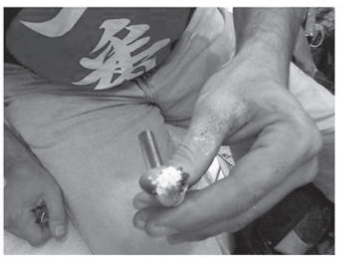

Fonte: Coleção pessoal do autor.

O "trago" acima foi feito a partir de crack em pó vendido em unidades de papelotes como se pode observar. Porém, não cor- 
roboramos a informação contida na pesquisa de Lúcio Garcia de Oliveira (2007) de que "a pedra tem sido progressivamente substituída por nova forma de uso, o farelo ou pó de crack". (OLIVEIRA, 2007, p. 95, grifo nosso) Em nossas observações de campo presenciamos a venda preferencial de pedras embaladas de crack e apenas uma única vez o crack em pó. Esta forma de apresentação da substância psicoativa foi relacionada pelo comprador com o fato da droga ser proveniente do final, ou resto de uma grande quantidade, originalmente dividida em pedras menores de crack. O pó seria uma espécie de subproduto da divisão do "tijolo" original em pedras pequenas para a venda. Abaixo, podemos observar na imagem obtida por Luana Silva Bastos Malheiro do crack em estado bruto, anterior a sua divisão em pedras para venda.

Figura 9 - Crack em estado bruto, anterior a sua divisão em pedras para venda

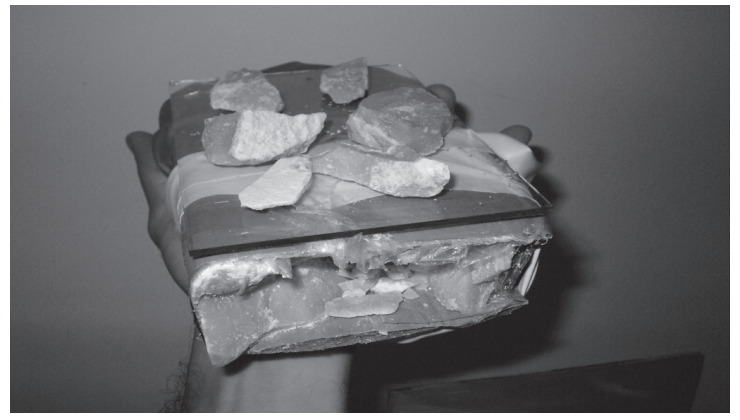

Fonte: (MALHEIRO 2013, p. 179).

Para Lúcio Garcia de Oliveira (2007) haveria uma tendência a se macerar a pedra de crack para posteriormente vendê-la em pó e assim, obter-se maior lucratividade. O papelote com pó de crack corresponderia a uma fração da pedra de crack original e seria comercializado pelo mesmo preço, aumentando o lucro do vendedor. 
Mesmo que não haja alteração de sua composição química, o farelo representaria uma forma mais rendosa ao traficante, já que amassariam as pedras e passariam a vendê-las na forma de farelo, garantindo que a quantia, antes referente à apenas uma pedra, fosse distribuída a dois ou mais papelotes, vendidos, cada um, pelo mesmo valor que o da pedra inicial, atitude, que por si só, acaba por justificar o desaparecimento das pedras do mercado como atualmente presenciado. (OLIVEIRA, 2007, p. 98)

Porém, mais que uma tendência, consideramos a venda do crack em pó uma exceção, ao menos nos locais por nós pesquisados. Mesmo considerando os ganhos potenciais dos traficantes, ele esbarra na grande disponibilidade de pontos de venda concorrendo entre si pela preferência dos usuários nas regiões estudadas, assim como da proximidade ou mesmo amizade e convivência entre usuários e vendedores, como foi o caso da "biqueira" com fumódromo em local fechado, por nós visitada algumas vezes. Lá, a divisão das pedras para venda era feita aos olhos do comprador, isto tende a dificultar a adulteração do peso do papelote, além de termos de considerar a disponibilidade de outros pontos de venda nas proximidades e mesmo dentro do mesmo lote, mais exatamente no barraco de trás. Isto possibilita ao comprador maiores possibilidades na escolha da melhor pedra de crack, enfim, o usuário de crack não mantém uma fantasmagórica passividade frente ao tráfico.

O desmonte do "chimbó" é feito para a retirada da "rapa", ou para algum reparo como trocar o isolamento de plástico que possa estar permitindo o escape de fumaça do "fogãozinho". Esta retirada requer a soltura do plástico derretido, geralmente grudado à parede externa do fornilho que veda o cachimbo ao prender o alumínio dobrado sobre as laterais da tampa do fornilho. Após a retirada da parte derretida, todo o plástico vedante pode ser removido, assim como o alumínio que tampa o "fogãozinho". Este pode ser reparado e/ou raspado, para retirada da "rapa" ali 
grudada que tende a fechar os furos do aluminio indispensáveis à entrada da fumaça oriunda da queima da pedra sobre ou misturada com cinza de cigarro. A retirada dessa borra requer um cuidado maior para não danificar o metal, principalmente no caso de um alumínio que se queira reaproveitar. Pode-se usar papel ou o mesmo plástico de vedação para a limpeza. Para a retirada da borra do "fogãozinho" e "caninho" usa-se material contundente, de espessura suficientemente fina para permitir-lhe alcançar e percorrer todo interior do "fogãozinho", "caninho" e encaixe quando houver. O "raspador" pode ser um pedaço de arame qualquer ou uma vareta de guarda-chuva, esta última muito valorizada por ser longa e possuir um formato côncavo apropriado à raspagem sem retirar material metálico das paredes do "fogãozinho". Este material caso retirado se uniria a "rapa" podendo influenciar seu gosto, assim como provocar males a saúde, ou seja, um procedimento espontâneo de redução de danos por parte dos usuários de crack.

No livro Retrato de um viciado quando jovem de Bill Clegg, o "raspador" é coincidentemente descrito como um pedaço da armação de guarda chuva. Em nosso país, sabemos do aproveitamento destes pedaços do guarda chuva para a fabricação de "caninhos", além dos raspadores. Porém, nos EUA, o cachimbo a ser raspado é significativamente diferente. Nesse país, como no Canadá, o crack é fumado em tubos de vidro como o pertencente à coleção do autor e mostrado a seguir:

O tubo de vidro é convenientemente disfarçado sob a aparência de uma caneta. Caso se tente escrever com a caneta, ela irá funcionar perfeitamente. A necessidade de disfarçar um produto destinado ao consumo de uma substância proscrita e estigmatizada pode ser ainda observada neste outro tipo de simulacro, na forma de uma rosa presenteável colocada em um tubo de vidro, chamada Love Roses ${ }^{59}$ :

59 Os tubos de vidro para consumo de crack, Love Roses, podem ser visualizados no link: <http://www.porkulent.com/2013/11/how-to-prepare-coffee/>. 
Figura 10 - Tubo de vidro para consumo de crack
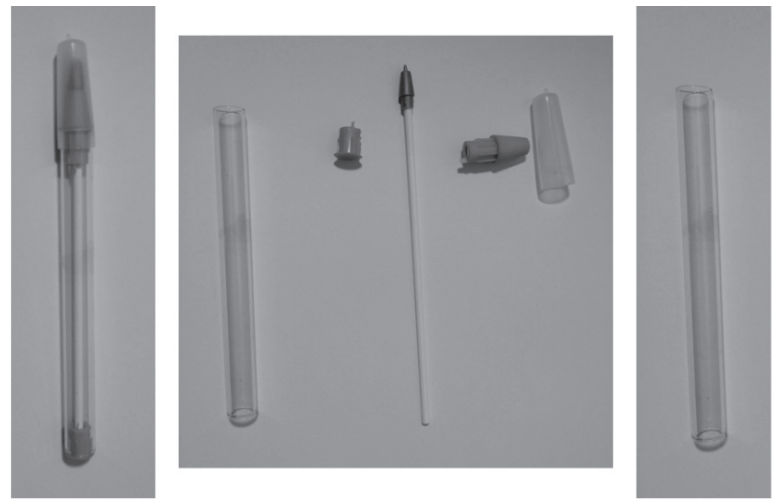

Fonte: Coleção pessoal do autor.

Esse tipo de cachimbo é completado por uma palha de cobre introduzida em uma das extremidades do tubo para possibilitar a queima da pedra. Podemos observar o conjunto completo nas imagens a seguir:

Figura 11 - Preparo do crack em tubo de vidro
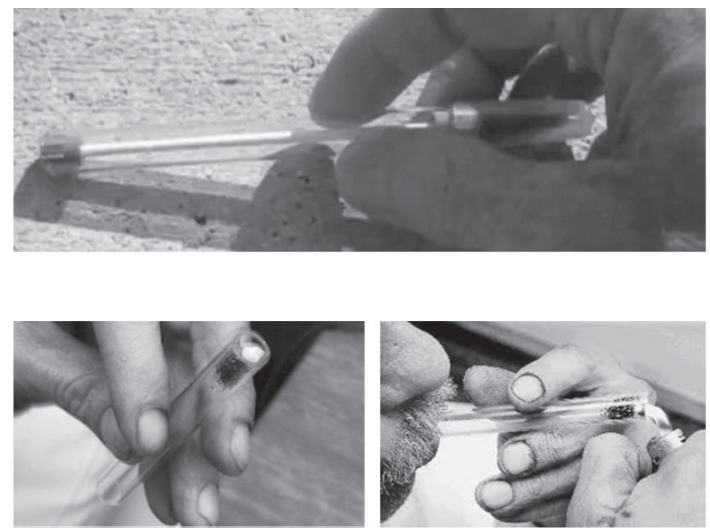

Fonte: http://www.sandiegoreader.com/weblogs/autobiography-channel/2011/aug/24/my-homeless-year-confessions-of-a-former-crackhead/. 
Vemos o conjunto na forma como é vendido e coincidentemente do mesmo tipo de nossa coleção. A pedra de crack é depositada sobre a palha de cobre $^{60}$ dentro do tubo de vidro, pronta para uso e a seguir, a pedra é aquecida para produção da fumaça. Esta fumaça passa pelo tubo até ser sorvida pelo usuário, porém, parte dela irá por arrefecimento, sublimar novamente ao estado sólido e depositar-se na parede do tubo. A "rapa" consiste nesse produto, posteriormente raspado para novo uso. O uso do raspador nestas condições é descrito no livro de Bill Clegg (2010) da seguinte forma:

'Passe o raspador', Mark grunhe. Seu cachimbo - um pequeno tubo de vidro com Bombril enfiado numa das pontas - está repleto de resina e por isso, depois que ele raspa tudo e coloca o Bombril de novo, a gente sabe que vai poder fumar pelo menos mais algumas vezes.

[...] Eu entrego para Mark a vareta de metal pontuda que até ontem à noite fazia parte da armação de náilon de um guarda-chuva. Raspadores são feitos de todo tipo de coisa - os mais comuns são de cabides de metal, aqueles sem pintura; mas as armações dos guarda-chuvas têm varetas longas e às vezes concavidades meio cilíndricas, que são particularmente eficientes para raspar cachimbos e conseguir uma ou duas tragadas milagrosas [...]. (CLEGG, 2010, p. 12-13)

O uso da marca Bombril, como ocorre na tradução acima, para designar a palha de cobre utilizada pelos usuários de crack dos EUA e Canadá pode levar a imprecisões. Bombril é uma marca de palha de aço e não de palha de cobre. A palha de aço queima rapidamente e produz uma fumaça tóxica, já a palha de cobre é bem mais resistente à queima e por isso mais propícia ao uso no cachimbo.

60 Uma conhecida marca de palha de cobre muito utilizada pelos usuários de crack norte-americanos, pode ser visualizada no link: <http://www. moneyboy.at/crack-aus-dem-automaten/>. 
Outro item importante do "maquinário"61 é o isqueiro, comumente chamado pelo nome da marca "Bic", não importando tratar-se de item original, o isqueiro da marca Bic, ou não. É possivel obter um "furador", ao romper a chapa por onde sai a chama e curvá-la para cima. Fora do uso, este "furador" pode ser reconduzido de volta à tampa por simples movimento de pressão. Assim, esta parte recortada da chapa é levantada por um movimento do dedo sobre ela, podendo ser utilizada para fazer os buracos necessários no alumínio do "boris" e, posteriormente, guardada outra vez.

Figura 12 - Isqueiro com furador

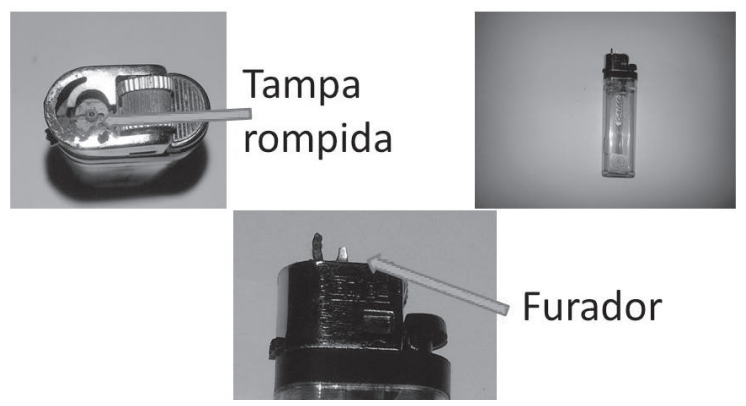

Fonte: Coleção pessoal do autor.

Na maioria das vezes, o "furador" é um pedaço fino de arame qualquer, ou mesmo o alfinete de um brinco que se preste à finalidade de produzir os furos necessários no alumínio do cachimbo. Sobre estes furos vai a cinza de cigarro, inclusive ao fumar-se no Yakult ou no copo de água descartável. O cigarro é fundamental para o consumo do crack. Isso é socialmente traduzido na figura do "cigarreiro", pessoa presente nos locais de consumo e responsável por abastecer os usuários com ci-

61 "Maquinário" é a categoria para referir-se ao que usualmente se chama de parafernália de uso, porém, é um termo mais apropriado dado sua complexidade como veremos abaixo. 
garros vendidos em maços ou a granel, ou mesmo trocados por "tragos". Ele é comumente chamado por este nome e, assim, o usuário necessitado de seus serviços pode simplesmente gritar "cigarreiro!" e logo este se aproximará com o maço à mão. ${ }^{62}$

\section{0 "boris" e a redução de danos}

A Associação Internacional de Redução de Danos (IHRA), sediada na cidade de Londres, define as práticas de redução de danos como aquelas que visam reduzir as consequências adversas do uso de drogas através da identificação de certos riscos específicos, suas causas e partindo de "um diagnóstico correto do problema". (IHRA, 2010, p. 2) Entre os anos de 2002 e 2005 foram realizados no Brasil, cinco projetos piloto de redução de danos entre usuários de crack e todos enfrentaram, de modo mais ou menos acentuado, imensas dificuldades. Estas foram atribuídas pela pesquisadora Andrea Domanico, a forma dos financiamentos dos projetos, marcada pela "ditadura dos projetos", e ao elevado grau de exclusão dos usuários atribuído ao "pânico moral" (DOMANICO, 2006, p. 9) em torno do crack.

Após pesquisa e análise dos projetos, Domanico tece diversas críticas e faz sugestões sobre a "ampliação do conceito de redução de danos para além da saúde" (DOMANICO, 2006, p. 175) e o estabelecimento de "canais de discussão entre os usuários e as equipes dos projetos”. (DOMANICO, 2006, p. 176) Para a autora, os projetos de redução de danos deveriam ser incorporados aos serviços de saúde como medida de saúde pública. ${ }^{63}$

62 A presença do cigarreiro diz respeito à Cracolândia ou lugares com um número considerável de usuários.

63 Seus participantes através da ação política e do protagonismo dos próprios "craqueiros" poderiam "incentivar as instituições não governamentais a exercer o controle social sobre instituições públicas, além das de saúde, para a criação de políticas de inclusão para os craqueiros". (DOMANICO, 2006, p. 192) 
Ao analisar o processo de popularização do crack e decadência do uso da cocaína injetável e seus efeitos sobre o trabalho das equipes de redução de danos acostumadas a trabalhar com troca de seringas e formadas, muitas vezes, por usuários de drogas por via intravenosa, a autora observa que: "Todos iniciaram suas intervenções com usuários de drogas injetáveis que tinham como prioridade a prevenção das DST/Aids e hepatites virais através do incentivo do não compartilhamento dos apetrechos para o uso de drogas injetáveis." (DOMANICO, 2006, p. 177) Isto levou os "cracados" - como eram designados aqueles que trabalham com redução de danos entre "craqueiros" - a repetir a prática “ 'instrumental' da substituição de insumos 'sem levar em consideração a solicitação feita pelos 'craqueiros'."(DOMANICO, 2006, p. 183) O fato seria também uma consequência da "ditadura dos projetos" que exigiria resultados mensuráveis e de curto prazo. ${ }^{64}$ Dois exemplos de pouco sucesso na distribuição de "apetrechos" voltados à redução de danos aos usuários de crack foram a piteira de silicone e o protetor labial. O primeiro foi inspirado em um kit distribuído aos usuários de crack da cidade de Paris e se revelou de dificil adaptação aos diversos tipos de cachimbos existentes. Atualmente, a distribuição de ambos foi abandonada pelo projeto pesquisado na época pela autora. ${ }^{65} \mathrm{O}$ que parece ser a comprovação da

64 "Todos os projetos já tinham equipes de redutores de danos trabalhando no campo, com a experiência anterior de trabalhos com o uso de droga injetável. Para o uso de droga injetável a resposta dos projetos e do próprio poder público na adequação dos insumos foi mais eficiente e ágil, na medida em que as equipes passavam a conhecer a realidade do uso injetável e informavam ao poder público que o equipamento disponibilizado não era adequado, a resposta era mais assertiva. Isso talvez porque para o uso de droga injetável as adequações dos insumos eram mais bem justificadas, como prevenção a doenças, enquanto que no crack a justificativa tem a ver com a melhoria da relação do usuário com a sociedade". (DOMANICO, 2006, p. 182)

65 "Este projeto parece ter conseguido a inclusão de um insumo que atendesse às reais necessidades dos usuários de crack atendidos, levando em consideração as especificidades do uso de crack daqueles usuários". (DOMANICO, 2006, p. 184) Porém, como observamos em nossa pesquisa de 
necessidade de seguirmos sua recomendação e de certa forma também da IHRA, de "ouvir o usuário e construir insumos que não alterem o seu ritual de uso". (DOMANICO, 2006, p. 184)

O cachimbo de fumar crack não se presta facilmente a técnicas de substituição ou acréscimo de apetrechos por ser um instrumento complexo, fruto de anos de aprendizagem e desenvolvimento em meio a um ambiente marcado pelo proibicionismo, mas ao mesmo tempo pelas possibilidades abertas pelos materiais e forças presentes no ambiente urbano. Ao contrário dos usuários de crack norte-americanos tanto estadunidenses quanto os canadenses, ambos presos ao produto industrializado, seja o tubo de vidro ou a palha de cobre, o usuário brasileiro é autônomo com relação à indústria, se valendo da reciclagem dos mais diversos materiais e não aceita se sujeitar à indústria, sequer via equipes de redutores de danos e suas tentativas de substituição de insumos.

\section{0 "bloco" e o "trago"}

Quando produzido no Brasil, o "bloco" ou pedra de crack é geralmente feito a partir do cozimento da pasta base da cocaína, ou "giz", com bicarbonato de sódio, isto pode ser feito, por exemplo, em uma panela de pressão sobre a chama de fogão doméstico ou em uma fogueira numa calçada, ou praça pública. Para aumentar a lucratividade, impurezas podem ser acrescidas como farinha ou maisena. Portanto, existem pedras com diferentes niveis de pureza e os usuários estão muito atentos a isto. Reclamam da má qualidade da pedra de uma "biqueira", deixam de adquirir em um local e o trocam por outro, exaltam a pedra da Cracolândia em detrimento do "bloco" do bairro e vice-versa. Podem comentar haver no bairro o melhor "bloco" e

campo na Cracolândia, esta distribuição teve vida muito curta e foi interrompida há alguns anos deixando raríssimas recordações entre os atuais frequentadores do local. 
no centro o pior. Assim, sua qualidade pode variar com o fornecedor, havendo "blocos" considerados do "tipo A, B ou C". Ou mesmo, com nomes próprios como, por exemplo, a pedra "Incrivel Hulk", este apelido é devido a sua cor esverdeada e alta qualidade. Há também a pedra "à óleo", feita exclusivamente da parte superior da fervura da pasta base com o bicarbonato e água, sem o acréscimo de impurezas. É um erro considerar o crack, uma espécie de subproduto da cocaína, tanto quanto a feijoada foi, há tempos, considerada "a sobra" do alimento da Casa grande. (BOLAFFI, 2004) A grande quantidade consumida em ambos os casos, não permite a produção por "restos". Fica aí, mais provavelmente uma questão de classe reforçada ideologicamente a partir de certos produtos.

Por esta forma de pensar, o crack do pobre e a feijoada do escravo só poderiam ser feitos a partir das sobras do leitão do senhor e da cocaína dos ricos. Mas não são! O crack é produzido da mesma pasta base da produção da cocaína, fato confirmado por relatos de quem produziu as duas variedades e pela literatura. (ARAUJO, 2012)

Figura 13 - Usuário desmonta guarda-chuva para retirada dos caninhos

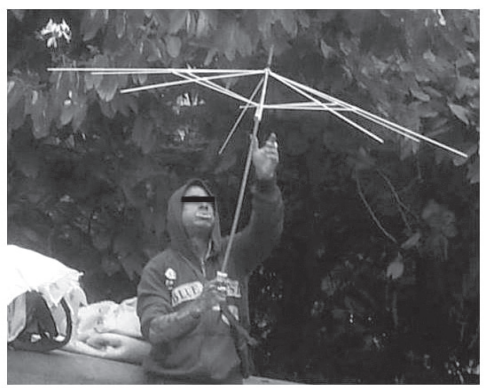

Fonte: Coleção pessoal do autor.

O tamanho da pedra é padronizado em uma cidade, ou região. Em São Paulo, ao adquirir-se uma pedra espera-se obter 
o suficiente para seis tragos, na cidade de Santos, o dobro. O "trago" é a unidade de consumo do "bloco". Pode significar tanto a quantidade colocada sobre o cachimbo ou "boris", quanto o ato de fumar. Alguém, ao "favorecer"66 outro, pode referir-se ao pedaço do "bloco" ofertado como trago, "está aí seu trago" e quem recebeu o pedaço da pedra, ao fumar, pode observar: "agora, vou dar meu trago". "Dar um bom trago" pode ser considerado o objetivo final do usuário e, para tanto, há de contribuir uma série de fatores. Mesmo esta unidade, o "trago", pode ser repartida como veremos agora. $\mathrm{O}$ ato de colocar a boca no orifício do "caninho" do cachimbo e aspirar a fumaça, enquanto o o "Bic" aceso queima-se a pedra, pode ser dividido geralmente em dois movimentos. No primeiro, comumente aquece-se previamente o "trago" colocado sobre a cinza do "boris" antes de iniciar sua aspiração. Com isto, o "trago" derrete e mistura-se à cinza formando um todo mais coeso e estável em comparação com o pedaço do "bloco" solto sobre o alumínio perfurado do cachimbo. Isto permite a movimentação do conjunto para os lados e facilita o contato com a chama evitando a queima dos dedos, particularmente o polegar, caso seja necessário inclinar-se o isqueiro $90^{\circ}$ para acender um cachimbo com o "fogãozinho" postado na vertical. Assim, é possivel compreender a existência de usuários habituais de crack que possuem os dedos preservados, sem queimaduras. ${ }^{67}$ Certa vez, perguntei a um "vapor" porque alguns usuários de crack deixam os dedos queimados e outros não:

Ygor - Esse negócio de queimar o dedo, também queima quem quer, né?

66 "Favorecer", no contexto desta frase, é o ato de fornecer crack a alguém, porém, com um comprometimento em termos de gravidade da situação e divida adquirida menor que "fortalecer" alguém.

67 Parece-nos que ao invés deste registro: "O constante aquecimento dos cachimbos fere ainda os dedos utilizados para bem posicionar o instrumento durante a tragada." (RUI, 2012, p. 271) A queima dos dedos deve ser buscada em uma dinâmica relacional mais complexa que a simples mecânica de uso. 
Dobem - Não, quem deixa se levar. 'Sou da marginália, sou do crack'.

Deixar os dedos queimarem e portar no corpo as marcas estigmatizantes de usuário de crack pode estar vinculado ao desejo de, através da marca corporal, demonstrar certa adesão a um grupo estigmatizado e a um modo de viver. Na relação usuário/cachimbo é possível acompanharmos, na prática, o vínculo entre estes dois actantes (LATOUR, 2008), onde não há mais dominadores (sujeitos) nem dominados (objetos). (LATOUR, 2001) Em que o corpo é posto em movimento e aprende a ser afetado pelas diferenças "rapa" branca/preta; cinza branca/preta; "fogãozinho" de cobre/aço; "caninho" curto/longo; alumínio muito/pouco perfurado e poderíamos listar mais uma gama de outros agentes neste coletivo. (LATOUR, 2012) Após aspirar a primeira vez, pode sobrar parte do "trago" não consumido sobre a cinza. Este será fumado em nova combustão sob a chama do "Bic". Assim, o "trago" estará completo. Ao mesmo tempo, entre um movimento e outro, parte da fumaça pode ser preservada após o "trago", no interior do cachimbo, bloqueando-se o "caninho" com o polegar. Tanto esta fumaça restante no interior do cachimbo quanto o resto de "trago" não queimado podem ser dados em "favorecimento" a alguém, ou "segundinha". Entra então, no circuito da "treta", tratada a seguir.

Figura 14 - Um "bom trago"

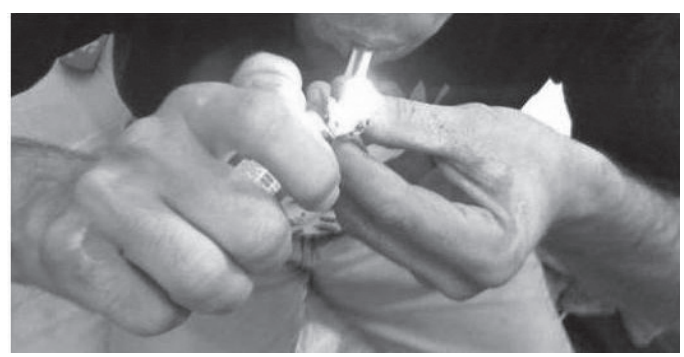

Fonte: Coleção pessoal do autor. 


\section{A roda de crack}

Pessoas sentadas próximas umas das outras, fumando e interagindo entre si, sob os efeitos excitantes da fumaça inalada, constitui uma prática, possivelmente, anterior ao surgimento das primeiras civilizações humanas e ainda está presente entre os usuários de crack. O cachimbo não passa obrigatoriamente de mão em mão, mas há um compartilhamento ocasional. Geralmente, cada usuário dispõe de um cachimbo próprio e este é constantemente aferido, arrumado, consertado, rearranjado e até mesmo refeito. É um processo de constante desestabilização e estabilização (LATOUR, 2012) em que o cachimbo de crack trabalha e não trabalha muitas vezes ao dia, por isto, não se permite que ele seja esquecido. É um não-humano avesso à invisibilidade e exige uma constante negociação, um actante em sua relação com o corpo, um mediador por excelência. Como um "bloco" pode ser dividido em seis "tragos" em média e como o objetivo da roda é proporcionar a todos um bom "trago", ${ }^{68}$ dificilmente ele será fumado na integralidade por um único usuário. Este será possivelmente convidado a "favorecer" ou mesmo "fortalecer" alguém. O primeiro termo tem um significado mais brando em relação ao segundo, que é mais trivial. "Fortalecer" alguém seria como fazer-lhe um imenso favor, enquanto ser favorecido significa ser ajudado, ou receber algo de valor, porém, sem resultar em uma grande divida ou obrigação. Ao pedir para ser fortalecido por um "vapor" em uma "biqueira", um usuário disse: "pode chamar nóis até pra carregar caixa eletrônico e pode pá”. Dispõe-se a trabalho perigoso em troca de um grande favor e faz do "vapor" seu credor.

A circulação dos "tragos", ou a sexta parte do "bloco", assim como do material necessário para o reparo dos cachimbos e consumo do "trago" como cigarro, "furador" e o isqueiro "Bic",

68 "Dar uma paulada" também é uma expressão utilizada que contém do mesmo sentido de dar "um bom trago". 
fazem parte da "treta". Nela, além do já exposto, entra tudo aquilo passivel de ser trocado: vestimenta, calçado, telefones celulares, relógios, água e comida. Embora, a venda ou mesmo a simples troca destes dois últimos elementos seja algo, muitas vezes mal visto, e é claro, o dinheiro. Um "trago" pode ser comprado por $R \$ 2,00$, ou trocado por uma camisa na roda de crack, antigos "favorecimentos" podem ser lembrados e retribuídos. Vínculos de amizade, relacionamentos amorosos e hierarquias são postos a prova e então confirmados, fortalecidos ou fragilizados e até mesmo destruídos. A "treta” é um agenciamento constantemente presente na rede social dos usuários; nela, diversas materialidades são colocadas em relação e traçam a tessitura das interações.

O ethos subjacente a estas práticas tem na "sintonia" seu sentimento positivo norteador e na "radiação", um traço negativo. A "sintonia" é o sentimento de confiança e empatia entre usuários partilhando a mesma droga, o contexto favorável à "brisa" deleitosa, uma agradável sensação de paz, segurança e comunhão. A "radiação" é seu inverso, trata-se da discórdia, da desconfiança e do medo. É o efeito de que alguma pessoa pode "meter o louco" ou "arrastar" outra ou mesmo, todo um grupo. É a quebra da reciprocidade, o roubo, a traição, o abuso de confiança e o desrespeito. Uma "brisa horrenda e medonha" também tem o poder de trazer "radiação". Pode arrastar ou contaminar todo um grupo e mesmo gerar "aproximação", expor aquelas pessoas, chamar a atenção sobre elas. Neste sentido, a "brisa" é também performance (ALMEIDA; EUGENIO, 2008) e parte constituinte do contexto de uso, como no diálogo abaixo, obtido em campo, com um ex-usuário de aproximadamente 35 anos de idade

Ygor - Cara, vem cá, 'brisa' é uma coisa mal vista, né? Antônio - Aí depende. A 'brisa', o efeito que ela dá. Tem 'brisa' que você fica, poxa, você acaba 'roubando a brisa do outro'. O que é de prazer, o que é de curtir. Porque você vai ficar preocupado com alguém que vai ficar olhando pra 
você. Assim, não fica sossegado. Então, o cara que tá curtindo numa boa... acaba tendo a atenção virada pra você. Ygor - O cara que tá curtindo numa boa, tá 'brisando' também.

Antônio - Claro. A sua 'brisa' é diferente. Acaba sendo 'medonha e horrenda'... e arrasta... 'O cara arrasta, meu. Você é louco'. Arrasta, ou seja, é muito mal visto. Chama muita gente pra ficar olhando. 'Fica chamando radiação pra cá'... 'Aproximação'. 'Não dá pra fumar com esse cara não. Vamos embora.' Tem cara que entra dentro dos hotéis e fica de boa lá, assistindo televisão a noite inteira, trocando ideia. Não fica encanado com ninguém. 'Eu tô pagando essa porra.' 'Tô pagando, tô usando a minha droga, não roubei de ninguém.' 'Vou ficar aqui de boa, cara." (Risos). 'Que se foda todo mundo.'

Estas materialidades presentes na rede social do uso de crack e que inclui os diversos saberes juntamente com o "bloco", o usuário, a roda de crack, o "vapor", cigarreiro, as cinzas, a comida, a água, o alumínio, o plástico, o "fogãozinho", o "caninho", os lábios, os pulmões, o fôlego, o Bic, a chama, o "furador", os dedos, a língua que sente o gosto e o aprecia ou não, o coração mais ou menos acelerado, todo o sistema nervoso, o barulho das sirenes, a radiação, o estômago e o sono. Todos se encontram em relação na rede de atores numa textura de agenciamentos. (LAW, 1992)

Vimos acima, como se dá um "trago". Agora devemos salientar seu aspecto coletivo. O proibicionismo e a ilicitude formam o pano de fundo, o dado estrutural fundamental do consumo de crack. Lidar com isso, ser capaz de usar sem medo é condição para a "sintonia" e, objetivamente, para a segurança do grupo desviante. A roda de crack não se encontra alheia ao mundo. É parte de seus valores, o respeito pelos não usuários. "Olha o anjo" é a frase pronunciada, por exemplo, na aproximação de uma criança e imediatamente o uso cessa em sinal respeito. $\mathrm{O}$ mesmo ocorre na passagem de qualquer não usuário por perto, como um transeunte. Os usuários são conscientes do impacto negativo causado pela sua prática e o evitam, tanto quanto, ou 
até mais, do que se guardam de serem vistos pela polícia. Não se encontram, portanto, fora de nossa cultura, mas fazendo dela uma leitura alternativa. Existem, assim, situações em que agirão dentro do considerado majoritariamente como "normal", enquanto, em outras, possam adotar comportamentos divergentes. (VELHO, 2013, p. 50) Certamente, existem situações em que pode ocorrer o uso individual, como quando, no decorrer de uma "caminhada", o usuário se encontra longe de seu local de permanência mais constante, ou então, quando ele estiver de posse de uma quantidade demasiadamente pequena da substância. Porém, o uso em roda, na companhia dos "parças" é o preferencial. Tanto dentro quanto fora da roda, a "treta" é generalizada. Além disso, insumos vindos de fora são frequentemente necessários e bem-vindos. Um usuário em uma roda pode chamar a atenção dos vizinhos para suas necessidades e possibilidades de troca: "Quem favorece água? Favoreço cigarro! Cigarreiro!”.

Para um neófito, aprendiz do uso do crack, o indicador de que está "brisando" pode ser um zumbido no ouvido. É muito comum ouvir a máxima "cada um tem sua brisa". Assim, esse aspecto idiossincrático da percepção dos efeitos (MACRAE; SIMÕES, 2000) deverá ser considerado em seu contexto social abrangente. A "brisa” certamente varia, mas esta variação, seja ela qual for, se dá em um contexto de uso. Um usuário, com formação acadêmica e de classe social superior à do comum dos frequentadores de certa "biqueira", pode "brisar" corrigindo reiteradamente a gramática dos demais participantes da roda de crack. Uma senhora por volta dos 70 anos de idade, frequentadora de uma "biqueira" com fumódromo, quando "brisava", se levantava e permanecia soturna e estática, com a bolsa sob o braço, como se fosse partir. Tal sinal corpóreo, tomado como indicador de que o uso está tendo os efeitos desejados, é procurado pelo novo usuário a partir de indicações feitas pelos outros na roda de crack, durante o processo de aprendizado 
(BECKER, 2008) para identificar efeitos e atribuir a eles uma positividade. Isto é similar ao que ocorre entre usuários de maconha em uma roda de fumo. (MACRAE; SIMÕES, 2000) "A 'brisa' boa é quando dá um tuim”. Ao perguntar a Salomão, um usuário, como era sua "brisa", obtive a seguinte resposta: "Depende do lugar e da circunstância". A "brisa" tida como sensação agradável depende da "sintonia" na roda de crack.

Zezé, o mesmo artista plástico supracitado por volta dos 45 anos de idade, encontrou-se certa noite cercado por revistas pornográficas em seu barraco e na presença de uma moça jovem e bonita, e informou que:

Zezé - Eu uso porque me dá prazer. Se todo mundo tivesse a 'brisa' que eu tenho, o crack não ia valer 10, ia valer 30 [...] Porque minha vida é boa, entusiasmado pra trabalhar, planejo e executo. E tenho um grande aumento da libido [...] A minha 'brisa' é a libido.

O mesmo usuário, alijado do contexto de seu barraco, sentirá outro efeito, não será mais o prazeroso conforme descrito acima, mas, o crack passará a servir como combustivel para o corpo fatigado. Mudado o contexto, altera-se o propósito, varia-se o efeito.

Zezé - Eu sou uma pessoa ainda presa a situações sociais que me deixam com vergonha, inseguro de fumar numa calçada. Não tenho brisa. Se estiver fumando em uma calçada é pra ficar acordado, pra seguir em uma caminhada. Não pra poder ter prazer. Prazer, pra mim, é estar fumando dentro de um barraco, lendo uma revista, trocando uma ideia, alisando uma gostosa. Mas na rua, ou eu tô ali, no meu limite. Lembra da agulha vermelha do combustivel já acabando? Eu estou na calçada, buscando uma treta pra me manter acordado até o próximo lance, um trabalho, o próximo [...]. (grifo nosso)

O uso no "corre", como observa o usuário Zezé acima, não é hedonista, mas voltado à produtividade do trabalho, é combus- 
tivel a ser queimado. Porém, este mesmo "corre" pode ser considerado como o ritual de obtenção de fundos para a droga. Um ritual absorvente e capaz de proporcionar a aventura de um dia inteiro para quem, de outra forma, poderia estar entediado ou frustrado. (LEARY, 1999, p. 432) O chamado binge de crack, ou seu uso até esgotarem-se todas as forças e posterior estado de prostração do usuário, pode ser compreendido na situação de rua, como associado a um estilo de vida. Como não há espaço físico para se dormir confortavelmente, o sono só viria como resultado e possibilitado pelo completo esgotamento de forças. Ao encontrarmos Zezé neste dia, ele havia acabado de acordar em seu barraco e estava bem-disposto, porém, juntou-se a nós um usuário que declarou estar cinco dias acordado, ele não possuía barraco e possivelmente só viria dormir no completo esgotamento de suas forças. Mais à frente veremos uma descrição pormenorizada do próprio Zezé sobre o uso até o esgotamento do usuário de crack.

O uso do crack pode estar ligado a "brisa" nas formas mais distintas possiveis, como a de Vó, descrita anteriormente e que consistia em levantar-se agarrar a bolsa, permanecer silenciosa, estática e aparentemente pensativa. O "corre" como é vivenciado pelos usuários pode corresponder àquilo que $\mathrm{T}$. Leary descrevia como uma aventura capaz de preencher um dia inteiro, porém, é interessante observar como a "brisa" pode preencher o cotidiano e transformar-se em estilo de vida. Como no caso abaixo, o de menina e ladra de rua:

Eu não gostava de traficar, porque a minha 'nóia' era roubar, onde eu estivesse. Podia ter até mil reais na mão, ter droga dentro da calcinha, que eu dava um 'pega' e tinha que roubar. Não sei por que, Eu tinha que roubar. Cada um tem um tipo de obsessão, a minha era roubar. (ORTIZ, 2001, p. 104)

Uma coisa muito boa também é ser honesta. Isso é legal, porque de vez em quando vem a vontade de roubar. Às vezes do nada vem a vontade. Às vezes eu seguro minha 
mão e ando assim no meio da rua. É mais no centro da cidade que me dá vontade. Então eu ando segurando minha mão, porque é compulsivo, roubar vira uma doença. (ORTIZ, 2001, p. 207)

"Brisa" de roubar em uma vida na rua como ladra. O efeito do uso do crack em determinado meio permite a exteriorização da "brisa" como disposição durável. Um princípio gerador de práticas regulares associadas a este meio, no caso de Esmeralda Ortiz, foi o centro da cidade de São Paulo e o ato de roubar. Assim, o uso do crack por uma menina em situação de rua como caso de Esmeralda pode predispor a um estado habitual de seu corpo, ao ponto de ela ter de segurar a mão, ser uma tendência, inclinação ou propensão, enfim, parte de um habitus como sistema de disposições. (BOURDIEU, 2003) Entender a "brisa" como uma disposição que em determinada exterioridade pode compor um habitus, nos abre a possibilidade de novo olhar sobre a expressão "sou da marginália, sou do crack" e a corporalidade do craqueiro. Ele, com seu andar peculiar, meio arrastando as pernas um pouco bambas, sua voz por vezes extremamente rouca, seus dedos queimados, a boca rachada e por vezes com um pouco de baba branca a se acumular nas laterais dos lábios. Acompanham estas características físicas suas roupas geralmente encontram-se sobrepostas em arranjos criativos de camisetas por cima de camisas e bermudas a cobrir calças. Assim, ser do crack é possuir certas percepções sobre os acontecimentos na rua, como a "radiação", ser capaz de certas apreciações, julgamentos e ações. Ser do crack é ter discernimento quanto aos riscos e possibilidades da vida em torno de uma "biqueira", enfim, dispor de uma "matriz de percepções, de apreciações e de ações" (BOURDIEU, 2003, p. 57, grifo do autor) que torne possivel a realização, entre outras ações, da "treta" e do "corre".

Ainda sobre a "brisa", outro usuário nos afirmou que fumar na rua, exposto à presença da polícia e de não usuários, lhe 
"rouba a brisa". William Burroughs fala em "tiranóia", a paranoia capaz de assemelhar todos a tiras. (BURROUGHS, 2013, p. 73) Portanto, para dar um "trago" e obter a "brisa" desejada não é suficiente, o importante serviço prestado pelo "vapor" aos usuários é proporcionar o "bloco" em locais com condições propícias à "brisa”. É possível dar o "trago", mas isso é considerado um desprazer, ou seja, dar um "trago" sem obter os efeitos desejados. Um local pouco apropriado pode tornar a "brisa" dificil ou mesmo impossível. Até uma companhia desagradável coloca em risco o "trago". Um "boris" mal calibrado, com furos a mais ou a menos no alumínio, pode tornar a tragada inviável a quem esteja sem fôlego devido a um longo período de uso ininterrupto. Um plástico mal colocado pode queimar e, assim, contaminar a fumaça inalada e estragar o seu sabor. Um "caninho" entupido pela "rapa", com comprimento ou largura inadaptado ao conjunto "fogãozinho" / alumínio, ou uma entrada de ar por fora dos furos do aluminio, assim como tantas outras combinações destes fatores fazem do cachimbo de se fumar crack algo de grande plasticidade e de dificil calibragem. Seus usos e os efeitos provocados são relativos aos diversos estados corporais do usuário, assim como ao seu estado de alimentação e descanso no momento da tragada. É corpo, contexto social (com o perdão de Latour) e propósito de uso entrando em relação com uma droga e os meios de administrá-la, e, todos em conjunto, ajudando a plasmar os efeitos percebidos. (FERNANDEZ, 2007) Como os atores são efeito das redes sociais (LATOUR, 2012), porque não irmos além e considerarmos os "efeitos" do crack, não mais como consequências do uso de uma substância, em um ambiente, dentro de um corpo, mas como efeito da rede. Há uma opinião corrente na academia de que não se consegue colocar em palavras estes "efeitos", mas ao compartilhar com Latour que "o que não pode ser dito pode ser articulado". (LATOUR, 2008) Somos convidados a pensar nos "efeitos" também como implicações da rede. A "brisa" não tem causa 
única na droga, ou em outro agente, mas está em relação com estas materialidades, sendo por elas mediada e transformada no coletivo.

\section{A roda de crack, a TAR e o cachimbo como "coisa"}

A chamada Teoria Ator Rede (TAR) nos permite atribuir à materialidade dos artefatos a agência própria dos atores, ao provocarem transformações no interior de relações, assim, não-humanos tornam-se mediadores pela sua força de transformação e agência. (LATOUR, 2012) Sem desprezar as pessoas, coube ao pesquisador assumir a heterogeneidade entre humanos e não-humanos e não sua simetria, na rede de relações. Para Latour, as associações entre estes elementos heterogêneos têm no social, não seu contexto, mas a sociedade passa a ser vista como a reunião destes elementos, tendo em vista que as ações são geralmente mediadas por equipamentos. Como vimos acima, não nos detemos apenas nos movimentos dos elementos humanos presentes no campo, mas por um princípio de simetria e negando a dicotomia ontogênica humano/máquina, nos atentamos também à agência dos não-humanos presentes no coletivo, principalmente o cachimbo de fumar crack. Essa produção conjunta do material e do social, os dois, partes do coletivo heterogêneo, foram descritas acima nos modos como estes são produzidos interativa e conjuntamente. Material produzindo social e vice versa, ambos mediadores, agenciadores e não simples intermediários, estes últimos transportando significados sem transformá-los (definir o que entra já define o que sai). Mas para os mediadores como o "boris", temos de considerar que: "O que entra neles nunca define exatamente o que sai; sua especificidade precisa ser levada em conta todas as vezes. Os mediadores transformam, traduzem, distorcem o significado e os elementos que supostamente veiculam". (LATOUR, 2012, p. 65) São enfim, capazes de afetar (LATOUR, 2008). Um computador em perfeito funcionamento é um intermediário, porém, 
ao apresentar algum defeito, torna-se fonte do tipo de incerteza que o pesquisador deve seguir, ou seja, um mediador. Como vimos, o cachimbo de fumar crack é como um computador constantemente quebrado e reajustado para transformar o "trago" em "trago". ${ }^{69}$

Em um materialismo relacional, o social é pensado em rede e a causalidade deixa lugar aos efeitos interativos, relacionais, no nosso caso, entre usuários, "maquinário", proibicionismo e todo o mais. Neste sentido, agência e estrutura devem ser pensadas em rede (LATOUR, 2012), sempre levando em conta que estamos constantemente na presença de vários atores, mesmo quando solitários, em relações heterogêneas que ultrapassam tempo e espaço. Assim, o proibicionismo estará presente no local mais seguro de uso e o cachimbo mais simples trará consigo as experiências de décadas de usuários. Mas, foi nas práticas que pudemos observar de perto como os mediadores fazem a translação e alteram circunstâncias em um resultado sempre inesperado (LATOUR, 2012) para cada ocasião. Um conjunto surpreendente de elementos humanos e não-humanos estão imbricados em agências capazes de produzir transformações, mesmo quando não estão fisicamente presentes, circulam.

Callon (2008) utiliza o termo "agenciamento sociotécnico" para tratar do que ocorre a partir do momento em que se introduz nesses agenciamentos "não só o corpo humano, mas os procedimentos, os textos, as materialidades, as técnicas, os conhecimentos abstratos e os formais, etc." (CALLON, 2008, p. 310) Um esclarece o outro como um conjunto de agências desenredadas aos poucos de um nó. Este desenlace nos permite compreender como o uso do crack, ao considerar-se a agência do cachimbo, fez do usuário um híbrido. Ao mesmo tempo corpo, destreza, saber acumulado, tudo em relação na rede social.

69 Vimos que "trago" pode ser tanto o termo utilizado referir-se ao pedaço ou pedaços da pedra de crack que irá se fumar, quanto ao ato de fumar ou "dar um "trago". 
Em um constante refazer, o usuário de crack refaz seu cachimbo conforme as necessidades do seu corpo. Busca materiais, os troca na "treta" e transforma-os em "coisa", num movimento renovado e vivido que busca "dar forma". O cachimbo industrializado seria a morte da atividade frenética do artesão, agora, engessada na forma acabada. O craqueiro não precisa de um plano de cachimbo pré-estabelecido na mente. Ele tenta, adapta, improvisa, molda, acomoda, compõe, inventa, põe em movimento, aviva e traz à tona os materiais (recicláveis) presentes como forças no ambiente. No processo contínuo de geração do cachimbo como "coisa", o usuário sempre busca uma forma nova e diferenciada de adaptar seu cachimbo conforme as necessidades do seu corpo, naquele momento particular. Os materiais presentes no "fluxo"70 são introduzidos em um fluxo de transformações. Neste sentido, o usuário está cercado de "coisas" que ele mesmo ou seus pares deram vida em um campo de relações que os engloba. O cachimbo, o barraco com seu mobiliário e o carrinho para carregar material reciclado.

Este improviso altamente criativo não demanda necessariamente de um plano, embora alguns usuários afirmem planejar e é claro que assim também podem fazê-lo. ${ }^{71}$ Mas, o que se pode vivenciar estando em relação com eles são movimentos criativos que, mais que um plano, parece seguir "linhas ao longo das quais as coisas são continuamente formadas". (INGOLD, 2012, p. 27) O cachimbo está sujeito ao corpo do usuário de crack. Ao seu fôlego, à sua boca com ou sem saliva, com ou sem feridas, mais ou menos inchada. Ao vento, à chuva, à maior ou menor quantidade de cinza disponível, à pedra e suas mais variadas possibilidades quanto à pureza, dureza, consistência e facilidade ou dificuldade em derreter sob a chama de intensidade variável. É neste entrelaçamento de aconteceres que se

70 Neste momento, nos basta saber que "fluxo" diz respeito ao movimento da pedra entre os usuários.

71 Zezé, um usuário artista plástico, afirmou planejar seu barraco. 
agregam todos os fios vitais a agir como forças sobre a criatividade do usuário, neles, o cachimbo de fumar crack é gerado e regenerado.

Observar o cachimbo é observar o usuário de crack em constante formação, ou reinvenção de si. O cachimbo real nunca fica pronto, portanto, não poderia ser planejado. O cachimbo é um mediador, mas também é "coisa". Manipulá-lo é coisificá-lo. Fumar crack é colocar em movimento um processo de coisificação. Não um encontro com um objeto, mas o ato de fumar. O usuário não está de posse de um objeto, mas atuando ao fumar e ato contínuo, transformando e dando vida à "coisa". Fumar crack é, então, uma maneira de habitar o mundo, de juntar-se ao seu processo de formação.

O alumínio perfurado é o chão do "trago". Fumar crack é misturar a substância da pedra ao meio volátil que a circunda, por mediação do cachimbo. Ele promove a mútua permeabilidade e conectividade entre o meio e a pedra. Um equipamento no qual o ar, se combina com a "pedra" e o fogo. Uma geofagia simbólica que sublima, pelo fogo, a pedra em contato com o ar, a "terra" que se mistura com o "céu". O cachimbo, sabiamente manipulado pelo craqueiro, coloca, assim, a pedra em relação com o fogo e o ar. Por meio dele, o fogo que queima, primeiramente, o ar, pode dar vida à pedra fazendo com que ela vaze e viva. Faz com que os materiais circulem e anuncia sua dissolução. O cachimbo tem sua forma dada na circulação de materiais (INGOLD, 2012) e nesta mesma circulação, sua dissolução e vida como coisa.

Os cachimbos dos redutores de danos, feitos em oficinas, são objetos sem vida. Eles só podem viver após serem imersos, como foram, nos locais de uso; aí tiveram que se tornar "coisas" e funcionaram mal. (DOMANICO, 2006) Colocado em movimento, o outrora objeto ganha forma em sua coisificação. $\mathrm{O}$ cachimbo é o seu tragar. Fora deste movimento, fora da "paulada", é morto. A paulada não é a interação entre uma pessoa, 
o usuário de crack e um objeto, o cachimbo. Se assim fosse, o cachimbo seria dotado de uma agência que, por vezes, se opõe ao usuário e o obriga a modificá-lo.

Para falar do cachimbo, seguimos seus materiais. Dentro do "fluxo" e do "fluxo", materiais, os mais variados, são combinados, adaptados e transformados. O cachimbo é composto por uma matéria-fluxo. (DELEUZE; GUATTARI, 2004) O usuário precisa estar sempre atento ao seu cachimbo para impedir que ele se desajuste a um corpo posto em mutação pela ação da fumaça proveniente da pedra. O usuário de crack e seu cachimbo são como o jardineiro e seu jardim, este sempre atento para que a mata não tome conta. $\mathrm{O}$ craqueiro experto lidando o tempo todo com o caos, com a vida que se recusa em ser contida.

O cachimbo para funcionar depende, todo tempo, da troca continua de materiais em seu interior, na sua superficie e fora dele. Um eterno dar forma criativo. O usuário de crack não faz sempre o mesmo cachimbo. Não repete uma receita presente previamente na mente. Ele segue os fluxos dos materiais disponíveis no ambiente, em um itinerário que acompanha a trajetória de sua vida. Os materiais, através do trabalho criativo, são trazidos à tona ao serem improvisados em coisas.

\section{Dois contextos para rodas de crack: o fumódromo e a Cracolândia}

O uso do crack depende do "fluxo". Ele garante a disponibilidade da droga e mantê-lo é obrigação do "vapor" para com os usuários e a "biqueira". Estar no "fluxo" é estar "na responsa", no dever de alimentar a "biqueira" com os "blocos". Não é à toa que o "vapor" está também no "corre". Às vezes ele está literalmente correndo, como pudemos observar, entre a "biqueira da Estudantes" e o fumódromo a céu aberto da rua São Paulo. Existem "biqueiras" stricto sensu, locais de mercado e não de consumo (FERNANDES; PINTO, 2004) como a Estudantes.

Penso na etimologia do termo "biqueira" correlacionado às filas formadas em frente às fontes de água em favelas, a bica 
d'água. Ao serem ocupadas pelo tráfico, as favelas passam a receber uma clientela de não moradores, interessada unicamente em adquirir a droga ilegal. A ilegalidade impede o comércio livre da droga e a exila a espaços igualmente ilegais, distantes dos ditames da lei. Quando conseguem se suprir de água encanada através de ligações clandestinas, os chamados "gatos", seus moradores deixam de ter de se postar em fila na bica. Esta situação fica reservada aos frequentadores não residentes que vão em busca da droga, para eles tão preciosa à mente e ao corpo, como água para a vida. A sede se fez fissura, a água se faz pó e pedra. Ao invés das latas d'água na cabeça, bolsos e mãos fechadas a "segurar o flagrante".

Ser "vapor" não é desempenhar o mesmo papel em qualquer lugar ou situação, independente do contexto. Ele pode ser mais ou menos ligado a "biqueira" ou estar mais ou menos por conta própria. À céu aberto, ou em lugar fechado. Pode acumular funções de gestão do local de comércio e uso, além de se responsabilizar pelo transporte dos "blocos", agora, agrupados no "pacote". Como uma espécie de concessionário, deve explorar e administrar um "espaço" de comércio ligado à determinada "biqueira". Tem a obrigação de manter o fluxo e o monopólio do lucro na venda do "pacote". Este lucro pode se dar na proporção de 14 para 10, medida observada em mais de um caso e confirmada por diferentes interlocutores. Cada "pacote", transportado ou recebido, possui comumente a quantidade não acidental de 14 "blocos". Isso é fruto do cálculo entre o risco da posse material do "flagrante" e sua otimização logística. Carregar mais "blocos" significaria correr maior risco de ser preso como traficante, por outro lado, ir e retornar da "biqueira" com uma quantidade menor obrigaria a um maior número de viagens. Um "pacote" comercializado por unidades de "blocos" a $\mathrm{R} \$ 10,00$ cada possibilitaria o lucro de 40\%, dado o valor a ser retornado à "biqueira". Isto, pelo fato do "pacote" custar $\mathrm{R} \$ 100,00$ e a soma obtida pela venda de 14 pedras ser 
de $\mathrm{R} \$ 140,00$. O "vapor" teria por lucro a diferença entre os $R \$ 140,00$ da venda e os $R \$ 100,00$ e retornaria para a "biqueira". Porém, a rotina e as motivações de um "vapor" não se restringem a um cálculo tão simplório.

Os "blocos" em um pacote costumam sair da "biqueira" embalados um a um, porém, sempre há a possibilidade do "vapor" ser responsável por estabelecer, por ele próprio, as unidades para comércio. Seu produto são os "blocos" fornecidos por terceiros, sua praça, a "biqueira” e o preço, em São Paulo, atualmente é fixado em por R\$10,00 por "bloco". Resta, então, ao "vapor" explorar suas possibilidades de promoção. ${ }^{72}$ Tendo essa liberdade, ele empreende todo o tempo. Nesse caso, trata-se de alguém que detém certa liberdade de ação e não de outro tipo de "vapor" que fica simplesmente postado em uma "biqueira", realizando o trabalho repetitivo de perguntar a quantidade, receber o dinheiro e entregar o "bloco". Um espaço de comércio e uso, muitas vezes, é abastecido por um "vapor/usuário". Do seu quinhão de lucro, de quatro pedras por "pacote", ele ou ela pode fumar uma, usar outra como moeda de troca pelos mais diversos bens e serviços, além de vender as outras na forma de promoção, por exemplo, seis pedras por $\mathrm{R} \$ 50,00$.

Devemos considerar o "fluxo" como interesse da "biqueira" e valor em si mesmo. Retornar à fonte para novo carregamento significa trabalho bem feito pelo "vapor" na comercialização dos "blocos"; maior chance de permanência na função e a possibilidade de barganhas por pacotes mais bem servidos e "blocos" extras. Um "vapor" incapaz de garantir e promover o "fluxo" poderá ser substituído, terá de encontrar outra forma de fazer seu "corre" e bancar seu consumo de crack.

O "vapor" desenvolverá habilidades de venda de acordo com as contingências de sua atividade. Anunciará sua chegada ao fumódromo em alto e bom som, "Ó, o blocão", assim como aler-

72 Os quatro Ps de Kotler: praça, preço, produto e promoção. (KOTLER; KELLER, 2006) 
tará sobre "as últimas do pacote", na esperança de alguém adquirir logo suas derradeiras pedras ante a iminência de ter de aguardar novo carregamento. Atualmente, as pedras de melhor reputação são a Incrivel Hulk e "à óleo", a tonalidade esverdeada da primeira a protege contra falsificações. O mesmo não ocorre com a última, assim, qualquer "vapor" da região central da cidade poderá declarar estar comercializando pedras à óleo. Este fato é semelhante ao ocorrido nos anos de 1987 e 1988, na região sudeste do país, com o despejo de 22 toneladas de maconha de excelente qualidade nas águas marinhas, pelo barco de bandeira panamenha Solana Star. A droga acondicionada em latas fez imenso sucesso e por alguns meses, todos aqueles dispostos a vender maconha declaravam estar comercializando cannabis "da lata". (AQUINO, 2012) O "vapor" precisa ter habilidades de negociação e ser o mais condescendente possivel com seus clientes. Estes avaliam o papelote oferecido para compra e o apertam para senti-lo. Mesmo após aberto, o usuário pode decidir pela troca caso não considere o tamanho da pedra condizente com suas expectativas. Quanto mais bem informado sobre a capacidade de compra dos frequentadores da "biqueira", melhor poderá o "vapor" promover a formação de consórcios entre os usuários e, assim, unir o possuidor de seis reais, por exemplo, com outro de quatro, possibilitando a ambos adquirir um "bloco" de R\$10,00 . Porém, quanto mais o "vapor" puder fugir da responsabilidade da partilha do "bloco", deixando-a para os usuários, melhor ele se sente.

O usuário de crack comumente reclama, assim, ele pode "radiar"73 falando, por exemplo, da seguinte forma: "Essa aqui tá ruim". Isto ele faz na expectativa de, em futuras compras, ter a quantidade aumentada, além disso, uma pedra de tamanho mais avolumado pode gerar expectativas e frustrações quanto às

73 "Radiar" é uma expressão êmica com o significado de trazer discórdia e incomodar. 
demais. Não faltam artificios ao vapor. ${ }^{74}$ Ele pode oferecer múltiplas variações de preço e quantidade ao interessado, ou então deixar os últimos "blocos" em consignação, enquanto busca o próximo pacote. Isto possibilita a manutenção do "fluxo" mesmo em sua ausência, pois está certo de que, caso apareça algum comprador potencial, a informação sobre a presença de algumas pedras, nas mãos de determinado usuário e disponiveis para venda, será imediatamente comunicada por algum "parasita", de quem trataremos mais à frente, ou pelo "contenção".

Fazer a "contenção" é uma atividade recorrente em "biqueiras" e fumódromos. Consiste em receber os usuários, manter o mínimo de "disciplina" e alguma segurança com relação a investidas da parte de policiais, assim como de outros possiveis invasores. Varia conforme o contexto. Em uma "biqueira" localizada em comunidade favelada, por exemplo, o "contenção" pode ostentar uma arma e ser responsável por verificar as condições dos clientes, obrigando-os a levantar a camisa e a barra das calças, para se certificar que estão desarmados. Assim, no espaço da "biqueira", seria ele o detentor do monopólio do uso legítimo da violência. É assim que tenta impor o mínimo de "disciplina" na fila de usuários, enquanto são atendidos. Neste ínterim, os usuários costumam reclamar do andamento do serviço, do fura fila, da qualidade da pedra ou comentam acontecimentos do dia relacionados à presença de polícia neste ou naquele local e discutem o estado de outras "biqueiras". Curiosamente, seu comportamento não é muito diferenciado do esperado para uma fila de banco, ou mesmo para pegar água na bica. O "contenção" deve também garantir o atendimento

74 O pagamento não precisa ser integral, "Troco pra galo (nota de $\mathrm{R} \$ 50,00$ )", caso o vendedor estiver sem troco pode deixar os "blocos" com o comprador e recolher o dinheiro depois. Essa técnica de vendas possibilita converter a diferença a ser dada por troco em nova compra algum tempo depois, quando os "blocos" inicialmente adquiridos tenham sido consumidos. A negociação pode incluir ofertas por quantidades maiores, cinco "blocos" podem ser oferecidos a $\mathrm{R} \$ 40,00$, por exemplo, inteirando o troco que deveria ser inicialmente restituído. 
preferencial e imediato às mulheres, que são colocadas em fila separada da masculina. Cabe também a ele, fazer certo esforço, embora geralmente sem muito sucesso, para impor o mínimo de seriedade correspondente a uma prática ilícita.

Em "biqueiras" menos estruturadas, o papel de "contenção" pode ser exercido por um "parasita" ali presente. Ao redor do "vapor" podem agrupar-se certo número de usuários, dispostos a prestar serviços em troca de um "trago". Quando a gestão do fumódromo é deixada, totalmente ou em parte, sob a responsabilidade do "vapor", este poderá valer-se dos "blocos" a mais auferidos em cada pacote para pagar pelos serviços necessários ao funcionamento do local. Fazer a "contenção" é um deles, assim como varrer o chão, retirar entulho, buscar água, trocar moedas por notas, arrumar o barraco do "vapor", entre outras atividades. Ao abandonar momentaneamente a "biqueira", o "vapor" pode deixar alguns "blocos" sob a responsabilidade do "contenção", até seu retorno.

Figura 15 - Esquema do fumódromo a céu aberto

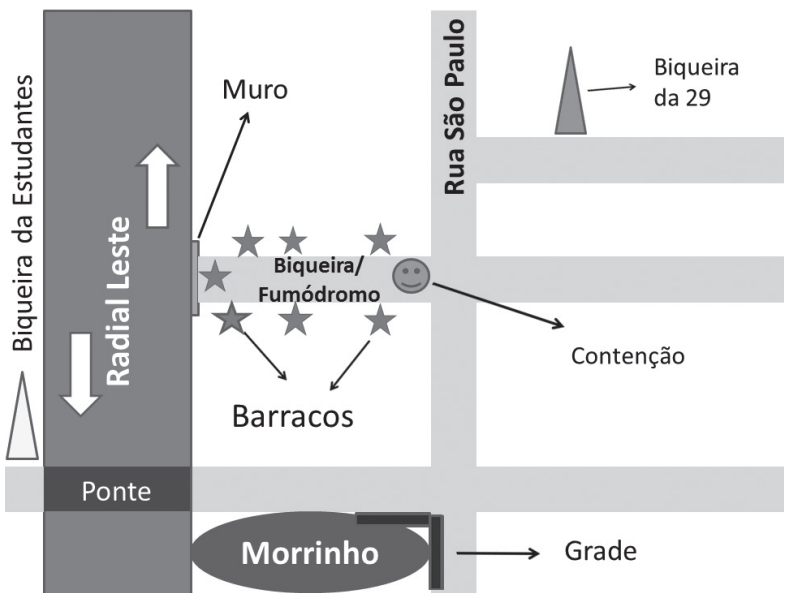

Fonte: Coleção pessoal do autor. 
Fazer a "contenção" em um fumódromo pouco estruturado é atividade menos importante em comparação à venda dos "blocos". A atividade pode ser desenvolvida por um indivíduo desarmado, ou em posse de uma faca para sua própria segurança. Um usuário antigo e frequentador do local não se sentirá intimidado pelo "contenção". Seu status não é muito superior ao deste usuário e mesmo o "vapor" só exerce maior ascendência sobre o grupo de "parasitas" a ele ligado e mesmo assim, de modo instável.

A contabilidade do "fluxo" leva em conta certas informações: quantas pedras foram deixadas, com quem, em qual ocasião, sob quais condições de preço e prazo para venda e tantos outros favores e serviços prestados. Ela é feita periodicamente no "resumo". Este encerra uma "situação" e é periódico. O "resumo" pode ser uma experiência desgastante e de certa tensão, dependendo da existência ou não de disparidades de avaliação entre o "contenção", o "vapor", alguma outra pessoa de referência no fumódromo e responsável pelo "fluxo" no momento, além de demais usuários ou "parasitas" que por qualquer motivo tenham retirado "blocos" para venda em uma espécie de consignação, ou "na confiança". Um representante dos interesses da "biqueira", presente no fumódromo com a finalidade de fazer o "resumo" irá acertar com o(s) "vapor(es)", ou mesmo com um terceiro traficante de referência, os valores alusivos à pacotes retirados e ainda não pagos. Os "vapores" acertam contas entre si, manejando inúmeras possibilidades de trocas, empréstimos e consignações de "blocos" deixados na confiança de alguém, para finalmente o "resumo" poder ser feito com a "biqueira". A diferença de postura e vestimenta entre os "vapores" e os traficantes de referência é notória. Enquanto os primeiros parecem desejar deixar claro o quanto "são do crack", os últimos fazem o inverso.

Como vimos acima, preservar os não usuários do impacto provocado pela visão do consumo de crack é um valor. Para 
tanto, recorre-se às tecnologias disponíveis na rua para o abrigo e intimidade. O barraco é a principal tecnologia disponível na rua para o abrigo e proteção; sua constituição é tão variada quanto são os materiais disponíveis, habilidade, propósitos e gostos pessoais. Pode ser construído a partir de materiais diversos como lona, papelão ou cobertores e ser apoiado em uma parede ou carroça. O barraco pode ter ou não um colchão, ser feito para se sentar ou deitar, ou mesmo para os dois propósitos. Surge, então, um ambiente íntimo, adequado para o uso seguro da droga, livre da vergonha de se estar agredindo os valores dos passantes, assim como da "radiação" O ambiente externo ao barraco está na verdade amplamente interligado a ele, porque a "biqueira" com fumódromo a céu aberto, por exemplo, é um lugar extremamente agitado, onde a troca recíproca de todo tipo de bem e serviço é constante. O barraco é suficientemente permeável a ponto de possibilitar a requisição de bens e serviços disponiveis no lado externo e, ao mesmo tempo, acompanhar alguma agitação maior na rua. Para a arquiteta Maria Cecília Loschiavo (2005), o barraco está relacionado a:

[...] culturas do desemprego, que levaram ao nomadismo, à bricolagem como formas de resistir à exclusão e criação de estratégias para sobreviver. Outro aspecto a ressaltar refere-se ao estabelecimento de uma justaposição da cidade formal com a cidade de plástico e de papelão, que frequentemente incorpora elementos do ambiente construído, como marquises, espaços residuais, baixios de viaduto, etc. (LOSCHIAVO, 2005, p. 14)

O barraco de alguém pode ser limpo e consertado por terceiros, tais serviços entrando no circuito da "treta". ${ }^{76}$ Não apenas

75 "Radiação" é o termo usado para designar distúrbios nas proximidades do local de uso. Ao perturbar o usuário de crack, eles prejudicam a fruição dos efeitos da pedra.

76 A "treta" é a troca generalizada de bens e serviços em torno do consumo do crack. Água, vestuário, cigarros, bebida alcoólica, itens da parafernália de 
os serviços, mas o próprio barraco pode ser vendido, trocado ou alugado. Ter um barraco em boas condições e muito frequentado é quase sempre garantia de acesso perene à pedra de crack. Sua construção e manutenção estão em consonância com a rua ou baixo de viaduto onde é erguido, sendo que antes do DBA, programa municipal dedicado à oferta de serviços aos usuários de crack, eles eram uma presença constante na Cracolândia. Foram retirados e sua montagem é muito controlada devido ao contrato estabelecido entre os representantes dos usuários de crack e a prefeitura. Mesmo assim, sua presença é constantemente incentivada pelo crime organizado, particularmente pelo Primeiro Comando da Capital (PCC), no sentido de melhor viabilizar o tráfico de crack na região.

Figura 16 - Confortáveis barracos na rua Helvétia, em meados de 2013. Em frente ao futuro ponto de apoio do Programa DBA, do outro lado da rua

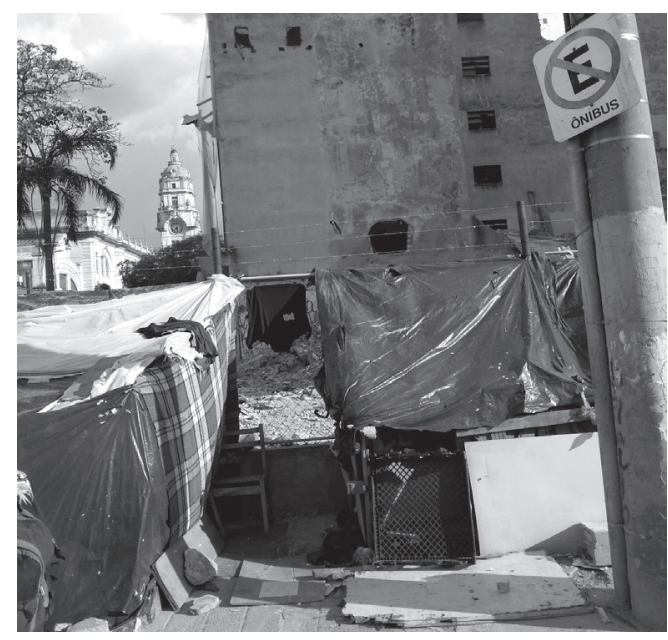

Fonte: Coleção particular do autor.

uso, assim como, serviços do tipo buscar água e limpar o local são constantemente trocados dentro e fora dos barracos. 
A lavagem diária das calçadas da Cracolândia, ao cair da tarde, constrangia e trazia instabilidade às acomodações, em uma situação de lumpen abuse. (BOURGOIS; SCHONBERG, 2009) Por isso, víamos lá, no início de nossa pesquisa de campo, no primeiro bimestre do ano de 2013, mais cenas de uso descoberto em comparação a outros locais de "fluxo". A Cracolândia é um espaço de uso e comércio intenso. Compreendia, no início de nossa etnografia, parte da rua do Triunfo e rua dos Gusmões, assim como o quadrilátero entre a Alameda Glete, a Avenida Rio Branco, a Avenida Duque de Caxias e a Alameda Cleveland. Neste espaço, entre a Praça Princesa Isabel e a Estação Júlio Prestes estão o Largo Coração de Jesus e a Praça Júlio Prestes.

A chamada Cracolândia está entre duas importantes áreas de práticas ilícitas na história recente de São Paulo: a antiga zona de prostituição do bairro do Bom Retiro e a Boca do Lixo. Até os anos 1930, a prostituição limitava-se à rua Timbiras, no limite da Boca do Lixo, do lado oposto à atual Cracolândia; posteriormente, essa área de meretrício foi deslocada pelo poder público para a rua Aimorés, no Bom Retiro, lá permanecendo até as vésperas das comemorações do quarto centenário da cidade, em 1954. Sua dissolução provocou o deslocamento de prostitutas, cafetões, punguistas e "toxicômanos" para a famosa Boca do Lixo. (JOANIDES, 1978, p. 15) Fica claro o quanto esse espaço é mutável. Contudo, há muito viceja na região uma tradição de práticas delituosas e passiveis de estigmatização. Até a implementação do Programa DBA, apenas a rua dos Gusmões mantinha, fora das proximidades da esquina da rua Helvétia com Dino Bueno, onde atualmente se localiza o DBA, o comércio de crack em pleno movimento, tanto durante o dia quanto no período noturno. Também durante a noite, a rua do Triunfo era ocupada por usuários nas proximidades do Largo General Osório, ${ }^{77}$ sendo que neste local se formava um "fluxo".

77 A região é repleta de "biqueiras" e hotéis com quartos disponiveis para curtos períodos e tolerantes com o uso, além de albergues privados com 
Próximo ao Largo Coração de Jesus, existiam, antes do DBA, ao menos quatro "biqueiras" "regularizadas", ou seja, ligadas ao PCC; e outras tantas independentes, além de uma infinidade de empreendedores individuais, usuários ou não, dedicados à venda do "bloco". Como podemos observar na breve declaração abaixo, onde está o Partido há "disciplina”.

Ygor - Quem é que bota ordem aqui no pedaço?

Mariano - Tem uns caras que botam ordem ai, mas nunca vejo. Tem os irmãos aí.

Mariano, um usuário com mais de dez anos de Cracolândia, certo dia nos falou a respeito de um "bloco" seu, que foi roubado enquanto dormia. Ele teria direito de cobrar, caso soubesse a quem acusar e poderia recorrer aos irmãos, conforme podemos verificar no seguinte trecho: "Cara que é safado, não tem conceito com os irmãos. É que aqui tem disciplina, certo?”. Após contar este fato, falou de um jovem "patrão", seu conhecido e por ele admirado pelas roupas caras e carro. Lembrou-me também de como sempre se portou de modo honesto com mercadorias, mesmo as mais caras, que lhe são entregues em confiança para "treta". Ele também nos contou a respeito das casas demolidas em uma das várias tentativas de extinguir a Cracolândia e comentou: "Lá era feio", segundo ele, cinco corpos chegaram a ser encontrados no local, no ano de 2011, e afirmou que: "Os caras que pilantravam”, ou seja, pessoas com dividas, eram lá assassinadas. "Os caras pegavam na rua e levavam lá", e completa a afirmação dizendo: "Tinha porão lá, então você imagina o porão". Existe um prédio ocupado por ciganos na esquina da rua Helvétia com Alameda Dino Bueno. Mariano conta a história de um cigano que entrou em atrito com um "irmão" e chegou ao ponto de ameaçar o membro do Partido com uma

preços de $\mathrm{R} \$ 7,00$ a $\mathrm{R} \$ 10,00$ sendo o leito em quarto compartilhado com direito a armário, banho e café da manhã. 
arma, isto provocou a vinda de diversos carros e homens do PCC, ligados ao irmão responsável pelo "movimento"78 naquele momento. Eles apontaram suas armas, segundo Mariano de pesado calibre, para o prédio onde residiam os ciganos, o que aparentemente os dissuadiu de continuar no conflito. Tempos depois, este cigano seria assassinado, o fato se deu, segundo Mariano, em 2003, dez anos antes de nossa conversa.

Aparentemente, a violência não precisa ser exercida todo o tempo, nem a presença ostensiva daqueles responsáveis pela "disciplina" se faz necessária para: "Fazer com que a vigilância seja permanente nos seus efeitos [...]". (FOUCAULT, 1997, p. 166) Os irmãos são temidos e admirados; estão presentes mesmo quando ausentes, pois podem ser acionados e rapidamente se materializarem na Cracolândia. Ainda mais importante, a "disciplina" está no orgulho de cada usuário em nunca roubar e na certeza de ter a quem recorrer em caso de ser roubado. O poder do Partido não é exercido pelo irmão de plantão a organizar o movimento. Fui apresentado a um deles e sequer aparentava estar armado. O assassinato brutal de cinco pessoas porque "pilantravam" permanece na memória, importando menos o seu efeito sobre quem é castigado e mais as impressões fixadas em todos aqueles que veem o castigo ou dele são informados. "Os caras que botam ordem", porém, nem sempre são vistos; cumprem o papel de um inspetor perfeito, omnipresente e invisível, mas acionável a qualquer instante.

O "fluxo" na Cracolândia criava tal densidade social, antes do Programa DBA, que chegava a ponto de gerar lojas comerciais dedicadas à "treta". Localizavam-se em imóveis das ruas Helvétia e Dino Bueno, assim como nas barracas de troca em pleno asfalto. Televisores, eletrodomésticos dos mais variados, fogões, geladeiras, cadeiras e joias podiam ser vendidos em lojinhas espalhadas ao longo do "fluxo". As barraquinhas sobre

78 O mesmo que "fluxo", ou comércio de crack. 
Jamais fomos zumbis

cavaletes ou diretamente sobre o leito carroçável, ou ainda na calçada vendiam e trocavam miudezas como canetas e aparentemente tudo o mais disponível. Persistem, mesmo após o Programa DBA, os cigarreiros. Não com um só maço para fazer "treta" a granel, mas com vários maços dispostos em uma caixa especifica para esta finalidade.

Figura 17 - O "fluxo" em meados de 2013, antes do Programa DBA

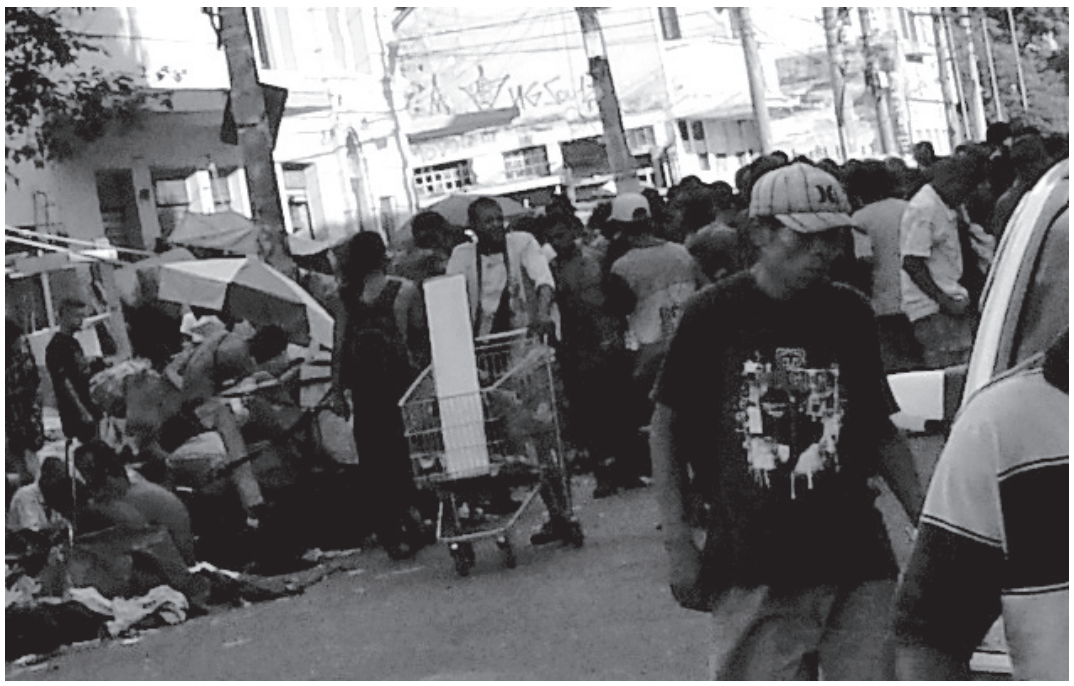

Fonte: coleção particular do autor.

Portanto, podemos entender o "fluxo" como uma aglomeração humana com dezenas ou mesmo centenas de usuários de crack a depender de diversos fatores, desde climáticos, passando pela repressão policial ao tráfico, até a proximidade ou não dos dias de pagamento. A disponibilidade da droga também é fator importante na construção e localização do "fluxo". Ele está onde há droga e vice-versa, o crack é levado para próximo aos usuários e estes, por sua vez, se dirigem para o local com maior disponibilidade de crack. Aparentemente, próximo ao "fluxo", ou melhor, dentro dele, os "blocos" são mais "bem fe- 
chados", termo êmico utilizado para se referir as pedras maiores e com embalagens ainda não violadas. Longe do "fluxo" as pedras disponiveis podem ser frações do "bloco" original, sem necessariamente ter um preço menor. Dentro e fora dele, pode-se adquirir qualquer fração do "bloco" até chegar a doses unitárias, ou seja, suficiente para um "trago". Estas frações da pedra original de crack são trocadas - também os mais diversos bens e serviços - dentro do circuito da "treta", tornando o "fluxo" um local de imensa agitação e até abrindo espaço a profissionais da "treta," ou indivíduos dedicados a comprar e vender objetos usados e novos.

A localização do "fluxo" variava antes da implantação do Programa DBA no decorrer dos meses, semanas e até dentro do mesmo dia. Ele podia se fixar por meses na rua Dino Bueno, entre as ruas Helvetia e Glete para em um único dia migrar para a esquina da rua Helvetia com Cleveland, ou mesmo ocupar os dois locais. Por vezes, o "fluxo" podia se desdobrar até o Largo General Osório, ou mesmo para a esquina da rua Glete e Avenida Rio Branco. Após a implementação do DBA, o "fluxo" passou a ocupar durante o dia, um espaço restrito em frente à sede do Programa. No período noturno, ele avançava um pouco mais pela rua Helvétia adentro. Mais recentemente, ele voltou a ocupar a rua Dino Bueno nas proximidades da esquina com rua Helvétia.

A presença dos serviços do Estado em atenção aos usuários era ostensiva na Cracolândia, mesmo anteriormente a implantação do Programa DBA. Lá, se encontravam há pelo menos quatro anos, as equipes de saúde com seus coletes azuis, andando em grupos de não menos três agentes. Também havia o posto policial, na esquina da rua Helvétia com a Alameda Barão de Piracicaba, cujas rondas buscavam colocar os usuários em movimento. Com viaturas que eram usadas para subir nas calçadas e desalojar seus ocupantes antes da implantação do Programa DBA. Se preciso fosse, os policiais desciam do veícu- 
lo e de arma em punho forçavam os reticentes a levantarem-se. Estas práticas, destinadas a forçar a motricidade e o deslocamento, parecem denunciar a submissão do trabalho policial à lógica do movimento reinante nas cenas de uso. Recordemos o "parasita", alheio ao "corre" feito pelos usuários em busca de fundos para adquirir pedras de crack. Lembremos também do "fluxo", da circulação do "bloco", seja entre os usuários, ou dos traficantes para estes. O trabalho policial dedicado a deslocar pessoas; empurrá-las de um lugar a outro, não estava em desacordo com os valores locais que privilegiam a agitação do "corre" e do "fluxo" ao sedentarismo do "parasita". Não se pode deixar de mencionar o funcionamento do serviço cotidiano de limpeza da rua, que não se restringe à varrição, mas também se valia de um caminhão pipa que deslocava os usuários pela iminência dos jatos d'água, fazendo-os caminhar p campo de forças onde se encontravam imersos. (RAUPP; ADORNO, 2011) 


\section{OS MODEL OS ANALÍIICOS, SUA ADEQUACZ̃̃O AO USO DO CRACK E A "COMMUNITAS" DOS USUÁRIOS}

"Nós somos a nova Jerusalém."79

São constantes os debates acadêmicos sobre o uso de drogas nos quais o contexto social em que este uso ocorre aparece apenas e tão somente como uma citação obrigatória da tríade: substância - indivíduo - sociedade. Disserta-se sobre a substância e sua ação sobre um organismo, quando muito considerando-se um ou outro aspecto da psique, porém, muito pouco ou quase nada se diz a respeito da situação do usuário no ambiente com que ele interage e sua influência sobre os efeitos da droga e os padrões de seu uso.

Este capitulo apresenta uma sequência de autores que no decorrer da segunda metade do século XX, desenvolveram um proficuo arcabouço teórico destinado a dar conta de ricas pesquisas com usuários de maconha, LSD, cocaina e heroína. Todos eles preocupados com a influência do meio social no aprendizado, efeitos, quantidade e propósitos de uso. São eles, o sociólogo norte-americano Howard Becker, e o psicanalista e psiquiatra, também estadunidense, Norman Zinberg.

As obras desenvolvidas pelos autores mais que se completam, elas compõem entre si um fluxo de pensamento. São produto de pesquisas que se sucedem e procuram, cada uma a seu modo, dar continuidade e superar desafios não plenamente resolvidos nos trabalhos anteriores. Assim será com Zinberg em relação à pesquisa de Becker com fumantes de maconha. Zinberg estará diretamente preocupado em como os rituais e regras presentes nas práticas de consumo de drogas ajudam na autorregulação destas mesmas práticas.

79 Corintiano. 


\section{0 modelo de Howard Becker e o uso do crack}

Após descrevermos o uso do crack, sua parafernália e as forças em seu entorno, podemos nos dedicar a analisar este uso a partir da literatura antropológica voltada ao consumo de drogas, na qual se destaca como pioneiro, Howard Becker. Em sua obra sobre o desvio, intitulada de Outsiders, Becker questiona a ideia de que a motivação ou mesmo predisposição ao uso de drogas seria derivada de suposta presença de algum traço psicológico particular. Para ele, esta seria a forma corriqueira de considerar o uso de drogas, presente em um grande número de teóricos, particularmente os estudiosos da maconha. Segundo eles, o uso derivaria de certa "necessidade de devanear e fugir de problemas psicológicos que o indivíduo não é capaz de enfrentar". (BECKER, 2008, p. 51) Em sua pesquisa, ele entrevistou 50 usuários de maconha, sendo metade músicos de jazz e o restante da amostra obtida por contatos inicialmente fornecidos pelos músicos.

Becker delineia sua visão a respeito do uso da maconha baseando-se no desvio, com motivos desviantes se desenvolvendo no curso da experiência com a atividade desviante (fumar maconha), em um movimento inverso ao proposto pela psicologia. Assim, para ele, o comportamento desviante acabaria por produzir a motivação desviante. Os impulsos e desejos vagos do neófito curioso são, no decorrer de sucessivas seções de uso, transformados em padrões mais definidos de ação por meio da interpretação social de uma experiência física, inicialmente ambígua. O padrão de uso da maconha de alguém - se ele continua ou não usuário, se usa mais ou menos da substância - seria uma decorrência de sua concepção a respeito desta substância psicoativa desenvolvida através da experiência no grupo de usuários. Vejamos isto de modo mais detido. 
Figura 18 - A interpretação social da experiência física

\section{Atividade/Experiência desviante}

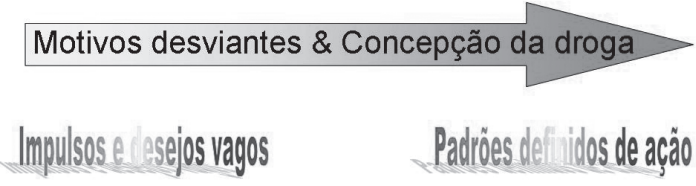

Fonte: Coleção particular do autor.

$\mathrm{Na}$ carreira do usuário procura-se compreender, a partir do desenvolvimento da experiência física e do modo como ele reagirá aos controles sociais existentes em torno da droga, "a sequência de mudanças na atitude e na experiência que leva ao uso de maconha por prazer" (BECKER, 2008, p. 52) (padrão recreativo, casual, não compulsivo). ${ }^{80}$ Dois problemas que aparecem ao se pretender inferir o uso de alguma droga a causas (traços) psicológicas. Primeiramente, muitos usuários não apresentam tais traços causadores e, em segundo lugar, a dificuldade encontrada por este modo de conceber o problema para dar resposta à grande variabilidade do comportamento em relação à droga, em um dado indivíduo, no decorrer tempo (a carreira do usuário). A mesma pessoa pode ser incapaz de usar a droga por prazer em determinado momento e ser capaz de fazê-lo no estágio seguinte, para mais tarde, retornar à primeira forma. Tais variações tornam-se compreensiveis como consequências de mudanças na concepção que o usuário tem da droga, passando, por exemplo, de alguém inicialmente inadaptado ao uso a alguém capaz de vislumbrar no uso de

80 O uso do crack também é por prazer. Mesmo para aqueles em situação de rua como se encontravam muitos de nossos interlocutores, o objetivo é dar um "bom trago" e não apenas saciar a fissura ou a abstinência. Isto seria, por exemplo, objeto do primeiro "trago" de uma pedra de seis "tragos". Os demais são fumados de modo prazeroso pelo craqueiro. 
Jamais fomos zumbis

determinada substância uma fonte de prazer. Desta maneira, Becker tenta alcançar uma:

[...] formulação geral da sequência de mudanças de atitude e experiência que sempre ocorriam quando o indivíduo tornava-se desejoso e capaz de usar maconha por prazer e nunca ocorria ou não era permanentemente mantida quando a pessoa não estava disposta a usar maconha por prazer. (BECKER, 2008, p. 54)

Portanto, existe uma carreira de uso. ${ }^{81} \mathrm{O}$ termo e o conceito de carreira foram trazidos por Becker da literatura de administração de empresas, particularmente da administração de recursos humanos, onde se tratava da carreira dos funcionários em uma empresa ou no Estado e as mudanças daí advindas. Assim, a experiência com o uso de uma substância é dada através do tempo e não apenas pontualmente - de uma única experiência de experimentação da maconha - porque para tornar-se um maconheiro "de sucesso", ou seja, aquele capaz de usá-la por prazer, se faz necessário insistir no uso mesmo em detrimento de uma má experiência. Neste trajeto percorrido ao longo da carreira de uso, uma série de mudanças de atitude com relação à maconha e ao grupo de usuários e não usuários vão se dando.

Becker focalizou em seu trabalho, o histórico da experiência do usuário com a maconha "procurando mudanças importantes em sua atitude com relação a ela e no seu uso efetivo e as razões dessas mudanças". (BECKER, 2008, p. 55) Assim como nós procuramos fazer neste livro, quando foi possivel e apropriado, ele usou o "jargão" nativo. Becker irá deter-se sobre três momentos de aprendizado, não necessariamente distintos:

81 Becker em seu estudo escolheu a maconha entre outros motivos por ser uma droga para ele incapaz de produzir síndrome de abstinência, o uso daí decorrente - das drogas capazes de produzir abstinência - é para aliviar seus sintomas de retirada. No caso do crack, nos foi relatado seu uso para aliviar a fissura, porém, é certo que se permanece fumando muito além do simples alivio destes sintomas e principalmente, fuma-se crack sem a necessidade de se sentir fissura alguma. 
o aprendizado das técnicas de uso da maconha, o desenvolvimento da capacidade de perceber os efeitos e finalmente, como aprender a gostar destes efeitos. O neófito, no mais das vezes, não sente, nem aproveita os efeitos da maconha na primeira oportunidade de uso. Se nada acontece, não é possivel "desenvolver uma concepção da droga como um objeto que pode ser consumido por prazer, e, portanto, o uso não continuará." Assim, "[...] ele precisa aprender a empregar a técnica adequada de fumar, de modo que seu uso da droga produza efeitos em termos dos quais sua concepção sobre ela possa mudar". (BECKER, 2008, p. 56) Tal mudança seria o resultado da participação do novato em grupos de usuários.

Figura 19 - Uso de maconha por prazer - Aprendizados

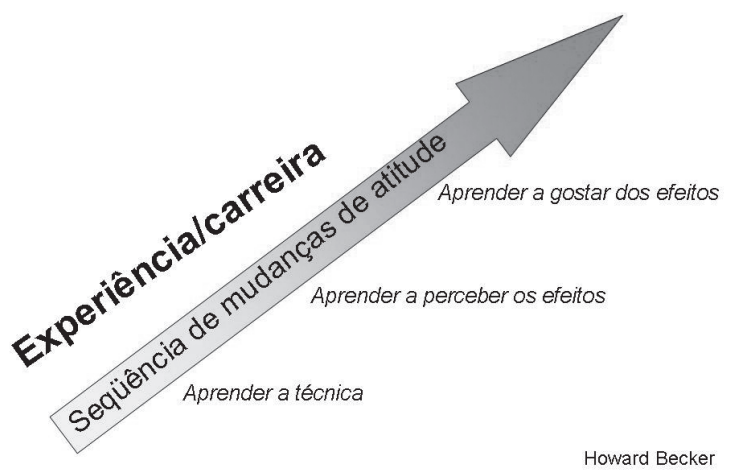

Fonte: Coleção particular do autor.

A iniciação abaixo, do primeiro uso de crack por parte de Esmeralda do Carmo Ortiz, mencionada anteriormente, presente em sua obra Porque não dancei, guarda semelhanças com o esquema de Becker e podemos perceber isto, nesta descrição:

Eu tinha 13 anos e dei o primeiro pega de verdade. Ficou um barulho estranho na minha cabeça. Eu fumei só por fumar e disse que não ia fumar mais nada. Eu 
disse: 'Vamos cair na correria, que é o seguinte, vamos se adiantar, se atrasar não dá'. Ela disse: 'Não, vamos catar mais uma. Quanto você tem aí?'. Eu falei: 'Tenho 15 paus, meu'. E ela: 'Pô, vamos fumar mais uma pedra'. Falei que aquele barato não dava porra nenhuma. Ela insistiu pra gente pegar mais uma pedra pra fumar. Eu falei que não estava a fim, mas ela insistia. Então eu fui e peguei mais um 'pino', que a gente chama também de 'papel', uma pedra de crack. Nós fumamos aquele papel. No primeiro pega não deu nada, no segundo pega não deu nada, no terceiro pega ela colocou o maior montão pra mim. Eu falei pra colocar pouco, que eu tinha medo de overdose, medo que a minha língua enrolasse. Eu colocava a língua pra fora, olhava pros lados, pra ver se não tinha polícia e falava: 'Sandrão, segura minha língua que eu vou dar um pega'. Não tinha como, tinha que colocar o cachimbo na boca, então comecei a entrar na 'nóia' que eu ia morrer de overdose. Fiquei morrendo de medo, de medo, de medo [...] Depois vi que não tinha morrido. [...] Catamos mais um papel e fumamos. Eu fiquei na light, numa boa. (ORTIZ, 2001, p. 95)

Percebemos claramente na exposição acima, da primeira experiência de uso de crack por Esmeralda, a falta de motivação inicial clara para o uso da droga ao afirmar: "fumei só por fumar e disse que não ia fumar mais nada". Vemos como sequer há uma vontade nítida de busca pelos efeitos e um grande esforço é preciso para a realização de novas tentativas com a necessidade de vencer o medo em momentos sucessivos, a partir da ajuda de uma usuária experiente. O efeito inicial do uso do crack encontra-se aí, muito distante da ideia pertencente ao senso comum a respeito da droga: a de um início inesquecível e ultra prazeroso o qual se continuaria buscando infrutiferamente nos usos posteriores. Como se a primeira experiência fornecesse um prazer absolutamente indescritivel e inigualável fazendo do pobre neófito um condenado à eterna busca infrutífera pela repetição impossivel do gozo inicial.

"O efeito é rápido, fazendo com que o usuário fique vulnerável à dependência logo na primeira vez que experimenta, 
despertando a vontade de usar cada vez mais. [...] O crack é a droga mais devastadora e pode provocar dependência desde a primeira pedra." (VIVA SEM DROGAS, 2014)

Esta crença, carente de comprovação empírica, pode influenciar no aumento do estigma sobre o usuário inicial da droga, tido como alguém definitivamente comprometido com a repetição deste uso até suas consequências mais profundamente danosas.

A degradação acontece em uma velocidade incontrolável, o usuário deseja droga a qualquer custo, sendo capaz de gastar todo o dinheiro, roubar coisas de casa para vender, se prostituir e até cometer crimes como furtos e roubos para sustentar a dependência. (VIVA SEM DROGAS, 2014)

Porém, vimos como o uso inicial do crack se assemelha ao esquema de drogas consideradas muito menos danosas como a maconha. O neófito não sente, necessariamente, os efeitos imediatamente após o primeiro uso e necessita da colaboração, confiança e incentivo de um usuário mais experiente para aprender a sentir os efeitos da droga. Isto é possivel a partir da superação das crenças negativas sobre o uso do crack adquiridas anteriormente, fora do grupo de usuários, como a crença vista aqui, da morte iminente por overdose: "Eu falei pra colocar pouco, que eu tinha medo de overdose, medo que a minha língua enrolasse”. (ORTIZ, 2001, p. 95)

No uso da maconha estudado por Becker, sentir os sintomas e vinculá-los à droga pode dar ao usuário, mesmo aquele novato no uso, a certeza íntima, porém, reafirmada e confirmada pelo grupo de pares, de ter sentido os efeitos da cannabis. Assim, “[...] um 'barato' consiste de dois elementos; a presença de sintomas causados pelo uso da maconha e o reconhecimento desses sintomas e sua vinculação, pelo usuário, com o uso da droga”. (BECKER, 2008, p. 57) De modo geral, pela observação dos que tem barato, o neófito insiste na experiência até obter e identificar os sintomas; ele aprende alguns "referentes 
concretos do termo 'barato' e aplica essas noções à sua própria experiência". (BECKER, 2008, p. 59) Como nos ensinou o usuário de crack Salomão, já mencionado anteriormente, enquanto estávamos no "morrinho": “A 'brisa' boa é quando dá um 'tuim", e por “tuim”, podemos entender um zumbido agudo nos ouvidos. ${ }^{82} \mathrm{Um}$ termo êmico para o ato de fumar crack é "dar uma paulada" devido à força atribuída ao efeito da droga. Estes referentes concretos dados no corpo do usuário, em sua percepção da realidade, das cores a sua volta, dos sons, as mudanças de humor características e desejadas, são todos passíveis de indicar para ele diferentes sensações que poderiam ser associadas com o uso da droga. Assim, um passo importante no uso de maconha por prazer, ou seja, aprender a sentir os efeitos, pode ser esquematizado conforme o diagrama abaixo:

Figura 20 - Uso de maconha por prazer - Efeitos Aprender a perceber os efeitos

\section{O "barato"}

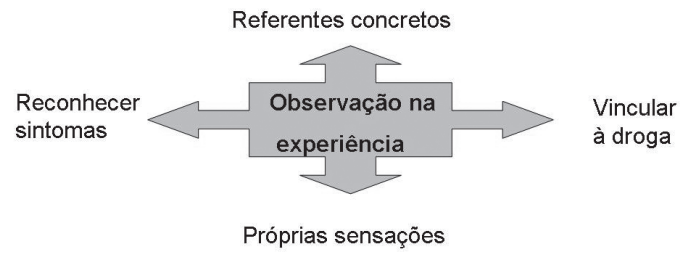

Fonte: Coleção particular do autor.

Uma vez reconhecidos os efeitos, trata-se agora de aprender a apreciá-los. O gosto pela experiência de fumar maconha é socialmente adquirido no grupo de pares e não algo dado de

82 Chegamos a ouvir o tal zumbido em uma de nossas ocasiões de uso durante a pesquisa de campo e imediatamente pudemos associá-lo a uma sensação agradável pela nossa orientação pregressa dada por Salomão. Esmeralda também parece ter ouvido: "Ficou um barulho estranho na minha cabeça”. (ORTIZ, 2001, p. 95) 
antemão como traço de personalidade, como presumido nas abordagens psicológicas criticadas por Becker. Ao investir em sua carreira de usuário de maconha "de sucesso", as sensações porventura desagradáveis, sentidas pelo novato em seu processo de aquisição de experiências de uso, deverão ser redefinidas para a continuidade deste mesmo uso. Isto se dá tipicamente em interação com usuários mais experientes capazes de minimizar a gravidade das sensações desagradáveis e chamar atenção para aspectos mais prazerosos e reconhecíveis dos efeitos. Por observar outros fazerem uso e constatar seu sucesso em usar por prazer é possivel ao novato tranquilizar-se em meio a uma experiência ambígua como vimos no caso de Esmeralda. Mesmo uma experiência desagradável poderá ser redefinida como algo agradável, prazeroso e até mesmo desejável depois do gosto pela droga - seja ela maconha ou crack - ter-se desenvolvido. "O prazer é introduzido pela definição favorável da experiência que uma pessoa adquire de outras" (BECKER, 2008, p. 65) na interação. Assim, uma nova concepção a respeito das sensações percebidas, adquirida na interação, torna possivel a redefinição positiva da experiência com a droga. Contudo, caso, após uma experiência negativa, não seja possivel ao sujeito redefinir o uso como capaz de produzir prazer, ele poderá cessar. Caso contrário, a carreira poderá evoluir como na figura a seguir:

Figura 21 - Uso de maconha por prazer - Interação

\section{Aprender a gostar dos efeitos}

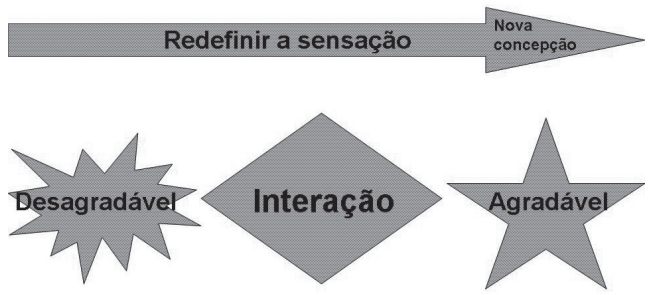

Fonte: Coleção particular do autor. 
Jamais fomos zumbis

Assim, alguém só se torna usuário após desenvolver uma disposição ou motivação que não poderia estar presente no início do uso, "pois envolve concepções da droga que só seria possivel formar a partir do tipo de experiência real". (BECKER, 2008, p. 67) Esta seria a experiência de aprender a usar e sentir a produção de efeitos reais, aprender a reconhecer estes efeitos e associá-los ao uso, e, finalmente, aprender a gostar das sensações percebidas. A partir daí, os controles externos sobre o neófito, controles estes que operam para valorizar certas formas de comportamento em detrimento de outros, como fumar maconha, podem entrar em colapso. Isto ocorre por consequência do ingresso em um "grupo cuja cultura e controles sociais próprios operam em sentido contrário aos da sociedade mais ampla" (BECKER, 2008, p. 69), emancipando-o destes controles e sensibilizando-o aos do grupo restrito de usuários da droga.

O neófito, no trabalho de Luana Malheiros (2012) sobre o uso de crack em Salvador, se assemelha ao perfil do "nóia", termo êmico ou nativo para designar o praticante do uso descontrolado. Ele se contrapõe ao "usuário", termo êmico que designa aquele capaz de fazer um uso controlado de crack. O "nóia", geralmente um neófito, faz uso em qualquer lugar, sem selecionar o ambiente e horário mais propício ao melhor aproveitamento dos efeitos do crack, além de usar na companhia de quem quer que seja e abandonar todos os seus compromissos em prol do uso. Claramente, no caso do "nóia", os controles externos entraram em colapso e ele passou a compartilhar um estilo de vida semelhante ao de outros usuários na mesma situação. Para modificar este estado de "coisas", outros controles externos se farão necessários para impor limites ao uso de crack. Porém, como Becker não tratou de uma droga da qual seja comum o uso abusivo, mas da maconha, estes controles serão mais bem tratados à frente, quando entrarmos em maior contato com a obra de Zinberg. 
Controles sociais afetam o comportamento pelo manejo de diferentes instâncias de poder e pela aplicação de sanções; também o fazem pela recompensa e punição de comportamentos valorizados e desvalorizados. Mas, no uso de drogas, surgem ainda controles mais sutis de influência "sobre as concepções que as pessoas têm da atividade a ser controlada". (BECKER, 2008, p. 69) Estas concepções são comunicadas em situações sociais, na interação com pessoas "consideradas respeitáveis e validadas pela experiência”. (BECKER, 2008, p. 70) Ou seja, os capazes de emprestar seu prestígio ao comportamento e às concepções valorizadas, particularmente em um grupo desviante. As sanções da sociedade abrangente se tornam ineficazes quando ocorrem eventos geradores de experiências apropriadas para alterar certas concepções, tornando adotar o comportamento desviante concebivel para a pessoa. Portanto, existe uma sequência de eventos e experiências na gênese do comportamento desviante capazes de suplantar os controles sociais que atuam no propósito de evitá-lo, como na figura abaixo:

Figura 22 - Uso de maconha por prazer - Carreira

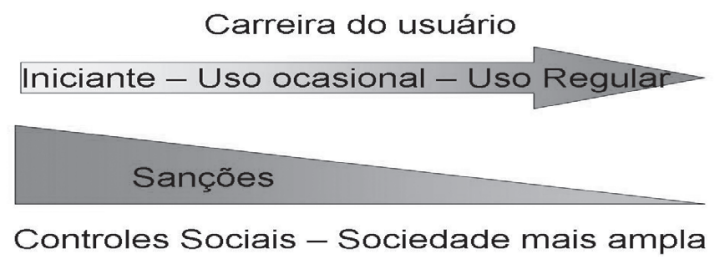

Howard Becker

Fonte: Coleção particular do autor.

Estes controles ou sanções da sociedade mais ampla partem da ilegalidade do ato e das severas punições passiveis dele advir, como a prisão. Assim como os controles e sanções podem surgir da atribuição aos usuários de maconha das característi- 
cas estigmatizantes associadas ao hábito. Como irresponsabilidade, falta de controle, ou mesmo loucura, além de outros tipos de sanções informais como ostracismo ou retirada do afeto por parte de entes queridos. Fazem parte destes controles a força das ideias ou concepções definidoras do uso da droga como violação de imperativos morais, ou ainda, como perda de autocontrole, paralisia da vontade e até escravidão.

Figura 23 - Uso de maconha por prazer - Carreira

\section{Controles sociais ou sanções sociais}

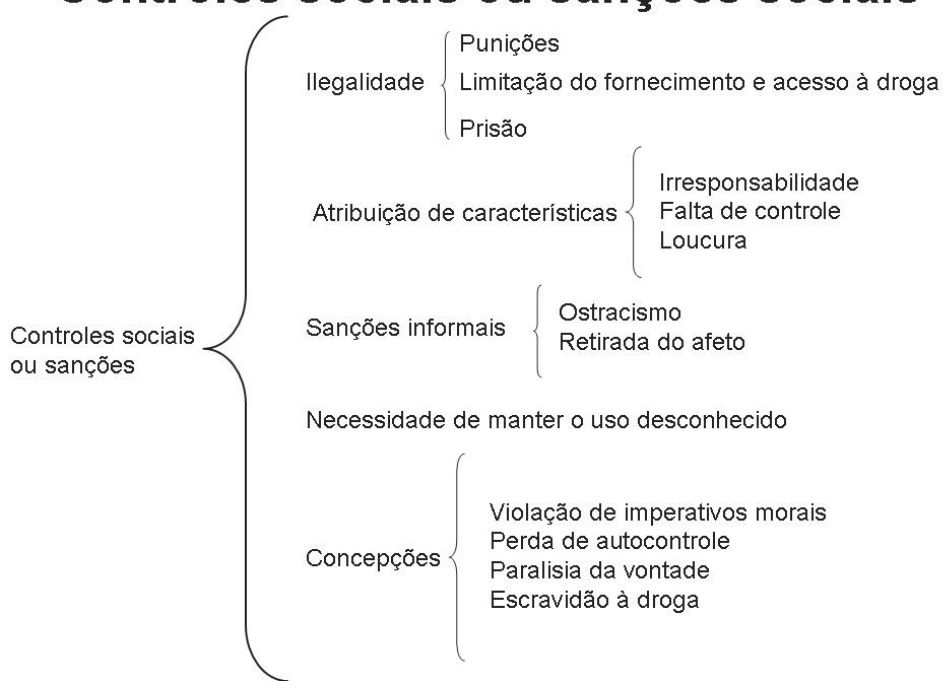

Fonte: Coleção particular do autor.

O pânico moral em torno do crack irá valer-se de muitas características do controle social descritas acima. Na sua relação com os controles da sociedade mais ampla e com a subcultura da droga, a carreira do usuário pode ser dividida em três estágios. O primeiro estágio é o de usuário iniciante; o segundo estágio é o de uso ocasional, esporádico; o terceiro de usuário regular, ou rotineiro. Em uma carreira de usuário de maconha 
bem-sucedida, os controles sociais do grupo desviante e os da sociedade mais ampla vão respectivamente ganhando e perdendo espaço de influência sobre o usuário. Quanto mais o uso deixa de ser ocasional e aumenta sua regularidade, mais este usuário ocasional fica cada vez menos receptivo às concepções a respeito da droga contrárias às do grupo desviante.

Figura 24 - Uso e controle social

\section{Carreira do usuário}

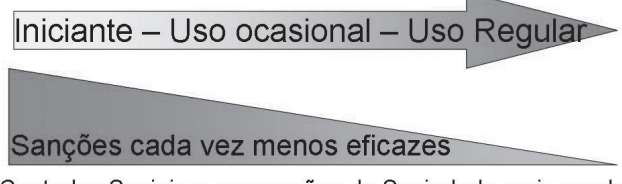

Controles Sociais e concepções da Sociedade mais ampla

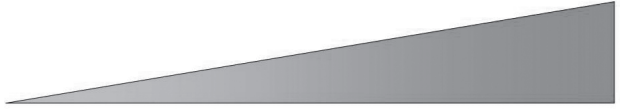

Controles sociais e concepções do grupo desviante

Fonte: Coleção particular do autor.

Porém, em nossa pesquisa sobre o uso do crack pudemos observar como o pânico moral, ou a ausência dele, no período anterior ao final dos anos 1990 do século passado, teve influência sobre a maior ou menor dificuldade para iniciar o uso do crack. Antônio é um ex-usuário cujo início de carreira se deu em meados dos anos 1990, mais precisamente em 1996 e não teve ele de enfrentar maiores receios ao iniciar o uso do crack. Segue abaixo, as suas declarações:

Antônio - Eu sou um caso à parte. Acho que todos os usuários de crack são um caso à parte. Cada um teve uma história de começo. E eu penso que esta história de começo, justamente nesse ponto que você fala sobre a concepção da questão do crack, penso que isso varia de círculo social. Meu círculo social estava como que normalizando, ou não tava [sic] colocando o fato do crack como uma coisa pesada, mas como mais uma droga. Eu não tinha visto 
ninguém usando; para mim era novo, 1996 era novo. Eu não sabia das consequências. Não tinha tanto 'nóia' na rua, não tinha tantos indícios de roubo por causa do crack, então, no imaginário social do meu grupo não tinha essa expectativa. Eu lembro que este círculo de amizade que começou a me apresentar essa porra desse crack, para eles isso era normal, normal não, era assim, uma droga pesada, uma vibe bem dark, sabe? Fui usar e não questionei sobre males e consequências porque não tinha em nosso círculo nenhum 'nóia'. Ninguém ficava virado, ninguém que roubava pra isso. Ninguém que tinha algumas consequências derivadas da droga, não tinha, não tinha. A galera não falava bem. Era outra vibe, o pessoal da escuridão, esse aqui é o pessoal da luz. Tinha uma certa separação e eram todos neófitos com respeito a... só tinha um que já usava bastante, mas ele não apresentava nenhuma característica de 'nóia'. Tinha controle. Nem se comentava isso na televisão, jamais, jamais.

Para dar início ao uso, foi aparentemente importante não haver usuários abusivos perceptiveis no grupo de neófitos, além disto, no caso de Antônio foi perfeitamente possivel iniciar o uso a partir de pouquissima experiência acumulada. Aqui, existe apenas um usuário mais experiente e mesmo assim, sua importância reside mais em não apresentar sinais de decadência que ser ele alguém capaz de ensinar a usar a droga. Assim, seu estado preservado e seu comportamento de usuário controlado contribuíram, aparentemente, para uma visão não tão negativa do crack e de ser seu consumo, algo possivel de usufruir sem maiores consequências deletérias. O fato de, naquela época, meados dos anos noventa, não haver ainda 'nóia' na rua nem tampouco furtos e roubos a eles associados, também parece colaborar para um início de uso da droga mais tranquilo.

No caso de Esmeralda, a falta de um modelo de usuário controlado imprimiu grande tensão à experimentação do crack. Rodeada por "nóias" - como são designados os usuários problemáticos em São Paulo - ela não possuía um modelo positivo capaz de tranquilizá-la quanto às consequências de usar crack e também quanto aos seus possiveis efeitos deletérios, como enrolar a lingua. Estes sintomas, de certa forma fantasiosa sobre os efeitos do crack, faziam parte das expectativas de Esmeralda 
e o modelo do "nóia" era para ela o comportamento esperado de quem fumasse. Ou seja, não existia para Esmeralda um modelo controlado de uso ao qual ela pudesse se apegar no futuro. Ao contrário, sua visão a respeito dos efeitos do crack e do próprio usuário eram as piores possiveis e em seu caso funcionaram, pelo menos em relação ao padrão "nóia" de consumo do crack, como uma espécie de expectativa auto realizada.

Retornando ao modelo de Becker, podemos ver como os vários tipos de controles sociais tornam-se cada vez menos eficazes na medida em que se avança na carreira de usuário. Assim se desenrola a consecutiva anulação de controles tais como: a limitação do fornecimento e acesso à droga, a necessidade de manter o uso desconhecido pelos não usuários e a definição do ato como imoral. Estes vão dando lugar às concepções do grupo desviante de usuários de maconha. No caso de Esmeralda, aparentemente, apenas as duas últimas destas três formas de controle operavam, pois, o acesso ao crack é praticamente livre na região central de São Paulo. Ela relata em seu livro a vergonha sentida após tornar-se "usuária forte" de crack.

O pior era que, quando amanhecia todo o pessoal que estava usando drogas comigo ia embora e só eu ficava ali, parecendo um bicho na ânsia de querer mais drogas. A loucura passava, a movimentação começava e eu ali, toda suja. Não aguentava ouvir o canto dos pássaros, aquilo me irritava, além da vergonha, pois as pessoas que passavam perto de mim atravessavam a rua ou saíam correndo, com medo de eu roubar as bolsas delas. Isso me irritava. (ORTIZ, 2001, p. 99)

Não é tarefa fácil manter o uso desconhecido pelos não usuários quando se está em situação de rua. Vimos acima, como o barraco é uma tecnologia de habitação e também forma de livrar-se do olhar acusatório do "Zé Povinho", aqueles que passavam perto de Esmeralda e saíam correndo com medo de serem assaltados. Mais que ser percebido como imoral, o uso do crack colocava Esmeralda em situação vexatória e isto a irritava. Possivelmente, a fazia ter o desejo de vingar-se dos tran- 
seuntes amedrontados levando-a a roubá-los mais uma vez e, em um processo retroalimentativo, o produto destes roubos forneceriam os fundos necessários para se fumar mais crack.

Para ter acesso à maconha, ainda no esquema de Howard Becker, deve-se geralmente participar de algum círculo não convencional, muitas vezes praticante de atividades e com valores opostos aos da sociedade mais ampla, capaz de tornar as fontes de fornecimento acessiveis. Ao afastar-se do grupo, o uso pode cessar pela falta de fornecimento, porém, uma vez usando dentro do grupo, os próprios controles internos sensibilizarão o novo usuário da necessidade de adquirir sua própria droga e não permanecer apenas sendo abastecido pelos demais. ${ }^{83}$

Figura 25 - Fontes de fornecimento

Fontes de Fornecimento

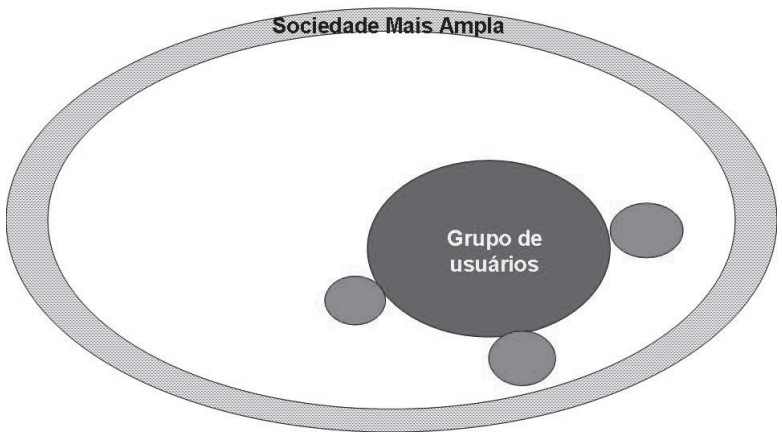

Fonte: Coleção particular do autor.

Para tanto, se faz necessário um "contato" e o conhecimento de onde encontrá-lo e de como apresentar-se para vencer qualquer hesitação à venda. Com a experiência aprende-se a avaliar o perigo próprio desta atividade ilegal e o risco deixa de impedir a compra. Então, o comprador passa a sentir-se seguro. O uso

83 No caso do uso do crack, o termo "parasita" parece retratar esta disposição. 
regular depende da estabilidade destas fontes de fornecimento e, a cada estágio, seja ele iniciante, ocasional ou regular, haverá um modo típico de fornecimento. "[...] a participação em grupos em que a maconha é consumida cria as condições nas quais os controles que limitam o acesso a ela deixam de operar". (BECKER, 2008, p. 75)

Vimos anteriormente, como o acesso ao crack é livre na região central de São Paulo, porém, isto não diminui a atração da fonte de fornecimento. Pelo contrário, ela é local de moradia de usuários de crack, como a "biqueira" a céu aberto, por nós pesquisada. A "biqueira", libertada das fronteiras do lote urbano, se projeta rua adentro para possibilitar uma maior proximidade com quem "é do crack" e lá, neste local de comércio e uso, através da tecnologia elaborada do barraco, alguns usuários podem ter sua moradia permanente e compartilhar não apenas da droga, mas, muito mais que isto, da vida na "biqueira". Veremos isto pouco mais à frente.

Figura 26 - Acesso ao fornecimento

\section{Fornecimento}

\begin{tabular}{lll}
\hline Iniciante - Uso ocasional - Uso Regular \\
Fornecimento & Início & Amplo acesso \\
feito pelo & da & a fontes \\
grupo & necessidade & de fornecimento \\
de usuários & de & \\
& fornecimento & \\
& próprio &
\end{tabular}

Fonte: Coleção particular do autor. 
Para os usuários de maconha pesquisados por Becker, o uso é limitado também pelo fato ou crença de que não usuários, cujo respeito e aceitação eles valorizam, caso venham a descobrir seu hábito, lhes apliquem sanções de algum tipo. Por isso, em sua maioria, os usuários de maconha são desviantes secretos e seus medos são contestados por racionalizações proporcionadas pela observação de usuários mais experientes, aparentemente impunes. Para o usuário ocasional, os pontos de contato com o mundo dos usuários regulares, que o convidam a se juntar a eles, parecem perigosos. Esta impressão se desfaz com o progresso exitoso na carreira de maconheiro, pela gradual, porém segura, substituição das concepções da sociedade ampliada pelas do grupo desviante. O neófito no uso, inicialmente encontra-se mais ligado à sociedade ampliada e seus pontos de vista sobre a droga e menos próximo do grupo de usuários, como podemos observar na figura abaixo:

Figura 27 - Sigilo do iniciante e usuário ocasional

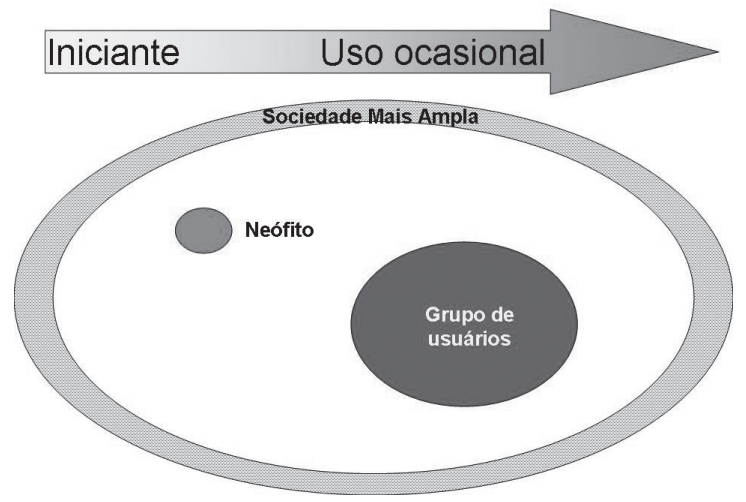

Fonte: Coleção particular do autor.

Quando o uso se torna regular, ocorre uma mudança na atitude deste novo usuário de maconha proveniente de uma mudança de concepção a respeito das oportunidades de consumi-la. 
Surge uma nova convicção a este respeito e ela passa a ser fumada sob o nariz dos não usuários, ou se adota um novo padrão de participação social que reduza quase totalmente as interações com os não usuários a niveis raros e sem importância. O uso regular só poderá permanecer caso se consiga lidar com os riscos de ser descoberto na posse da droga e ser capaz de esconder seus efeitos quando na presença de não usuários. Caso consiga controlar melhor os efeitos de seu uso com uma eficiente administração dos sintomas aparentes, capazes de denunciar o usuário ao não usuário de quem ele está desejoso de manter seu novo hábito em sigilo, ele poderá continuar a manter contato com estes não usuários. Porém, quanto maior a dificuldade em manejar sintomas como: confusão, olhos vermelhos, cheiro e dedos amarelados, mais o usuário regular será induzido a permanecer mais tempo com o grupo desviante. A própria fruição dos efeitos desejados a partir do consumo da maconha pode levar o usuário regular a se afastar de não usuários no intuito de melhor aproveitá-los. Administrar os sintomas em frente aos "caretas" pode consumir parcela importante do prazer em utilizar a droga.

Figura 28 - Sigilo no uso regular

Uso de maconha e controle social - Sigilo

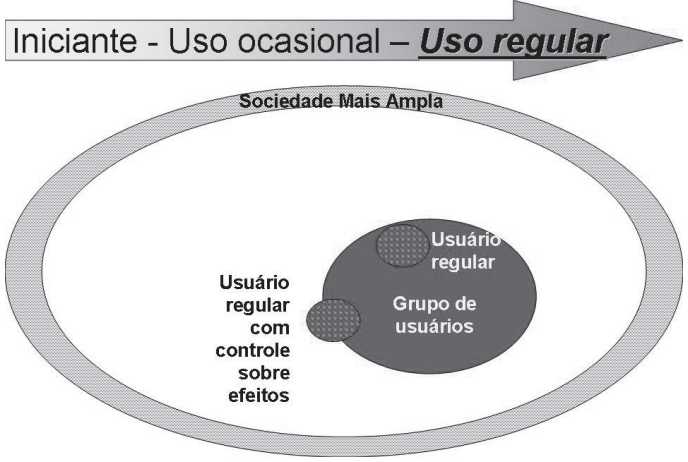

Fonte: Coleção particular do autor. 
Estes apontamentos de Becker a respeito da relação entre o usuário de maconha, os grupos de usuários e a sociedade mais ampla nos será de capital importância para procurarmos compreender o fenômeno da "biqueira" a céu aberto e mesmo a Cracolândia. Um usuário de crack da Cracolândia, de vulgo Mariano, com quem compartilhamos muito da "sintonia" em nosso processo de interlocução, nos revelou morar com sua avó, além de passar temporadas na Cracolândia. Lá, ele podia usar crack, o que era vedado em sua residência e fazia isto há mais de dez anos. Voltava à casa de sua avó regularmente, porém, os períodos na Cracolândia eram de duração superior. Como os outros frequentadores do local, ele se dedicava com afinco à "treta" e lá possuía seus "parças", inclusive um primo de vulgo Corintiano que também pudemos conhecer. Outro caso semelhante é o de Carazinho, o primeiro usuário de crack com quem tivemos interlocução na Cracolândia. Carazinho, como muitos outros membros da população flutuante do local, andava munido de uma mochila presa às suas costas. Nela carregava seus instrumentos de trabalho como pintor de paredes com compressor de tinta. Após receber o pagamento por algum serviço, dirigia- se à Cracolândia para consumir crack e rever os "parças". Quando terminava o dinheiro, poderia retornar ao trabalho abandonado, ou procurar nova ocupação temporária. Assim, a mochila nas costas e sua habilidade como pintor qualificado o permitiam um modo de vida desprendido de maiores vínculos. Assim como Mariano, Carazinho possuía local de moradia fora da Cracolândia, porém, era um local para onde procurava dirigir-se o mínimo possivel, por ter problemas de relacionamento com seus parentes. Os problemas de relacionamento também estavam presentes na casa de Mariano e ambos declaravam serem estes problemas decorrentes do uso de crack.

Tanto para Carazinho quanto para Mariano, ambos na faixa dos 40 anos de idade, estar na Cracolândia era sua maneira de 
livrar-se da desaprovação familiar ao uso, possivelmente eles não conseguissem controlar os efeitos do crack a ponto de poder utilizá-lo próximo ao convivio familiar. Mas não era apenas isto o que os afastava deste convivio. Como observou Howard Becker, para poder desfrutar dos efeitos prazerosos da maconha, se faz necessária a companhia de outros maconheiros e distância de não usuários, capazes de obrigar o maconheiro a dispender um grande esforço em disfarçar os efeitos da droga ao invés de aproveitá-los. Vimos como os efeitos prazerosos do crack dependem da "sintonia" entre usuários e de como isto só é possível na companhia destes. Além disto, o uso do crack pode prolongar-se por dias ininterruptos, dificultando ainda mais sua fruição nas proximidades da companhia familiar e aproximando, portanto, os usuários uns dos outros. Para fumar crack, é melhor estar na companhia de outros craqueiros. Para estar na companhia de outros craqueiros e não comprometer sua "sintonia" é necessário fumar crack. A prática da "treta" possibilita a todos o fruir da pedra, democratizando seu acesso. Uma "biqueira" a céu aberto, ou mesmo a Cracolândia são locais onde se pode estar livre da companhia julgadora de não usuários, sejam eles familiares, amigos, colegas de trabalho ou faculdade, e, ao mesmo tempo, estar na companhia de outros usuários com quem se pode viver a "sintonia"; assim como das fontes de fornecimento e circulação da pedra através da "treta". Situação similar pôde ser observada por Christiane F. a partir do final dos anos 1980 do século passado, no parque da Platzspitz em Zurique.

No final da década de 1980, o parque da Platzspitz se tornou o ponto de encontro de viciados expulsos de outros lugares. Por muito tempo tolerados pela polícia e pelos políticos, os drogados vinham de toda Suíça e do exterior. A maioria vivia na pobreza e financiava o vício com roubos ou prostituição. Na margem dos rios, várias pequenas comunidades foram construídas com caixas e coisas jogadas fora, pois a maior parte dos viciados não contava com abrigos na época. As habitações provisórias 
eram regularmente derrubadas pela polícia, mas as autoridades começaram a temer que o Platzspitz acabasse se tornando uma área marginal livre. (FELSCHERINOW; VUKOVIC, 2014, p. 98)

A Suiça também viveu seus tempos de Operação Dor e Sofrimento $^{84}$ e aparentemente, como descrito acima, o uso da heroína também produz seus guetos, ou praças de uso como a Platzspitz. Até mesmo os barracos estão presentes para garantir o mínimo de proteção contra o olhar, além do sono reparador após um possível longo período de uso. Porém, nos interessa aqui pensar sobre as razões de surgirem locais de uso coletivo $^{85}$ de certas drogas, como a Cracolândia paulistana, a Platzspitz de Zurique ou os "espaços legalize” de Salvador/BA.

'Legalize' é uma categoria nativa, possivelmente soteropolitana, que se refere a certo contexto social e simbólico, situado no tempo e espaço, onde o consumo público de maconha é tolerado socialmente. Isso não significa que este não seja ilícito, mas sim que os grupos sociais dispostos entre pares que dividem o espaço delimitado podem consumir, ou não a erva ilegal sem maiores preocupações com os controles formais e repressores. Em termos gerais, o que caracterizaria um espaço urbano 'legalize' seria um estado de liberdade relativa, no tempo e espaço, para o uso de maconha e/ou outras drogas ilícitas em um dado território geográfico urbano público ou privado. (SANTOS, 2013)

Norman Zinberg (1984) também chamou a atenção para ocasiões especiais com o envolvimento de multidões no uso de drogas como bebedores de cerveja em jogos esportivos, maconheiros em concertos de rock e mesmo o uso de vinho e coquetéis em refeições e finais de tarde, de tal modo que:

84 Violenta ação repressiva realizada na Cracolândia, no início de 2012, pelas administrações Alckmin e Kassab frente aos governos municipal e estadual, respectivamente.

85 Não é a droga que produz estes locais de uso coletivo. 
[...] apesar de suas diferenças culturais, tornaram-se tão generalizadamente aceitos que pouca ou nenhuma restrição legal é aplicada mesmo que tal uso quebre a lei. Por exemplo, um policial pode dizer a adolescentes bebendo cerveja em um concerto a céu aberto para 'pararem com isso', mas ele raramente irá prendê-los; e em muitos estados americanos a reação policial poderá ser similar mesmo se a droga for maconha. (ZINBERG, 1984, p. 6, tradução nossa)

Com o intuito de permanecerem desviantes secretos, usuários de crack, heroina e também de maconha procuram locais onde o uso da droga não interfira em seu relacionamento com não usuários, cuja aceitação eles valorizem e que lhes possam impingir sanções morais, sentimentais, físicas ou financeiras. Em companhia de outros usuários de drogas e em locais não frequentados pelos não usuários por eles valorizados conseguem permanecer impunes. Há, portanto, uma disposição à aproximação cada vez maior com o grupo de usuários das Cracolândias, Platzspitz e dos "espaços legalize" e uma disposição contrária às interações com não usuários, principalmente os mais próximos, ou cujo julgamento seja mais valorizado. A presença de usuários "bem sucedidos", como visto anteriormente no caso de Antônio, ajuda a promover uma concepção mais positiva sobre a droga e sobre a possibilidade de seu consumo com sucesso ou por prazer. No caso de Esmeralda, o fato dela encontrar-se em situação de rua desde a infância e ser ainda uma jovem adolescente, a expôs às concepções da sociedade mais ampla sobre o uso do crack de um modo ampliado pelas experiências drásticas de uso existentes em seu universo de rua. Ela só pôde vencer tais interdições com o auxílio paciente de sua "parça" mais próxima.

Existem dificuldades de ordens diversas para se usar drogas na presença ou na proximidade de pessoas valorizadas pelo usuário. Ser descoberto é correr o risco da desqualificação decorrente do estigma criado pelo pânico moral em torno do uso e 
do usuário de drogas ilícitas. É correr o risco de sofrer sanções legais que podem chegar até a prisão como foi o caso da Christiane F. adulta, de Mariano, de Carazinho e de Esmeralda. Ser um desviante puro (BECKER, 2008), ou aquele que demonstra possuir um comportamento infrator e é percebido como desviante, enfim, "ser do crack" expõe esta pessoa à grande probabilidade de ser taxada como irresponsável, descontrolada ou mesmo louca. Mariano, em uma entrevista profunda, nos informou a respeito de seu relacionamento problemático com a avó e sobre uma espécie de profecia feita por seu avô, ainda quando ele era menino e morador de uma cidade do sertão nordestino. Seu avô disse que ele "não daria em nada", ou seja, não seria nada na vida e as prisões de Mariano por roubo de veículo e outros crimes vieram confirmar a maldição do avô perante toda família. Neste sentido, o uso do crack foi mais um capítulo em uma história marcada pela progressiva retirada de afeto por parte de seus familiares, até colocá-lo em situação semelhante à de rua, se considerarmos seus longos períodos nas calçadas da Cracolândia. Assim sendo, estar na Platzspitz ou na Cracolândia é uma forma de ostracismo impulsionada pelas concepções e sanções advindas do proibicionismo com relação às drogas tornadas ilícitas e a sua expressão ideológica, o pânico moral. A carreira do usuário nestes casos se torna uma carreira de progressiva exclusão da sociedade abrangente e de inclusão em um grupo desviante organizado, com todo o impacto que isto tem sobre a concepção da pessoa sobre si mesma. Ela passa a assumir que "sou da marginália, sou do crack", adotando uma identidade desviante, advinda de um sentimento de destino comum aos usuários de drogas. Com todos sujeitos às mesmas leis que os criminalizam, aos mesmos estigmas e compartilhando um entendimento comum sobre o mundo ao redor e suas ameaças e possibilidades, uma cultura desviante pode surgir. Define-se assim, um cotidiano, um modo de vida, ou, como muito bem apontou o usuário de heroína e escritor W. 
Burroughs: "O barato junky é ter de viver sob condições junkies". (BURROUGHS, 2013) A esta vida junkie é perfeitamente possível ter-se acesso na Cracolândia, na Platzspitz e de certa forma nos "espaços legalize". Digo de certa forma porque o estigma em torno da maconha atualmente, no Brasil, nos parece algo distinto do vivenciado por Becker nos EUA do início dos anos 1960 do século passado, portanto, a necessidade da manipulação dos sintomas do uso da maconha pode ser menor em relação ao crack. Mas isso não significa de modo algum, que o usuário de crack fique mais "antissocial" que o usuário de maconha ou de cerveja. Nossa experiência de campo comprovou como o ambiente da "biqueira", ou mesmo da Cracolândia pode ser extremamente cordial na ausência de maiores conflitos relacionados à distribuição ou aquisições de crack. Estas divisões são feitas de modo cortês na imensa maioria das vezes e entre pessoas que se conhecem há certo tempo por serem frequentadoras do mesmo espaço. Sabemos que, para Becker, garantir o sigilo é condição para o avanço bem-sucedido na carreira de usuário de maconha, seja ele mantido pela competente administração dos sintomas ou pelo afastamento com relação aos "caretas". A tendência a isolar-se da sociedade mais ampla e socializar-se preferencialmente com outros maconheiros é proporcional à capacidade de administração destes sintomas e ao desejo de consumir regularmente a agora, tão desejada e prazerosa maconha.

A menos que descubra um método para superar essa dificuldade, a pessoa só pode avançar para o uso regular quando a relação que impede o consumo é rompida. As pessoas não costumam deixar seus lares e suas famílias para fumar maconha regularmente. Mas se o fazem, não importa por que razão, o uso regular, até então vetado, torna-se uma possibilidade. Usuários regulares confirmados muitas vezes consideram seriamente o efeito do estabelecimento de novas relações sociais com não usuários sobre seu uso de droga. (BECKER, 2008, p. 78) 
Usar crack e conviver com parentes é mais que uma questão de manejo de sintomas, é também uma questão de manejo de um agenciador físico (FIORE, 2013), a fumaça. Tal qual o usuário de maconha, o craqueiro se vê às voltas com as dificuldades de usar sua droga sem ser denunciado pelo aroma característico da sublimação da pedra de crack, pela luminosidade emanada do "Bic", pelos dedos enegrecidos pelo contato com a cinza de cigarros, pela fumaça e luminosidade do próprio cigarro, pelo cheiro a impregnar as vestimentas e cabelos, pelos lábios ressecados e às vezes rachados, pela voz grave, pela baba branca a ocupar o espaço das extremidades dos lábios e enfim, pelo desejo de estar entre iguais e partilhar da "sintonia".

Para não ser necessário romper as relações com não usuários seria preciso aprender a controlar os efeitos da droga e prosseguir como desviante secreto. "Os imperativos morais básicos que operam aqui são os que exigem que o indivíduo seja responsável por seu próprio bem-estar e capaz de controlar seu comportamento racionalmente". (BECKER, 2008, p. 82) Estes imperativos, relativos aos usuários de maconha capazes de controlar os sintomas provenientes do uso e abastecer-se competentemente da droga, não corresponde ao estereótipo do usuário de drogas irresponsável e despreocupado com sua performance. Como podemos observar neste trecho de um artigo sobre o consumo de maconha:

E o uso da Cannabis passa a ser um ato rotineiro e, aos poucos, essas sensações agradáveis começam a mudar: o relaxamento vai virando preguiça, a calma vai transformando-se em lassidão, a melhora do humor e do otimismo começa a virar postergação, a necessidade de fazer coisas que não se gosta de fazer, começa-se a deixar para mais tarde. "Depois eu faço"[...], 'Amanhã eu faço[...]', o aumento das ideias criativas vão se tornando uma criatividade apenas teórica ‘Tudo bem...'. (KWITKO, 2014)

Para o usuário não condenar a si mesmo negativamente como desviante é preciso que desenvolva uma visão alternativa, 
da qual fazem parte racionalizações e justificativas diferenciadas das ideias convencionais presentes na sociedade ampliada, sobre a suposta escravidão às drogas. Isto é possivel pela interação em um segmento não convencional da sociedade, possuidor de um repertório de respostas às objeções sociais e mesmo de acusações aos modos de ser da sociedade, como a acusação de cinismo àqueles que se entregam a práticas nocivas como o consumo do álcool e certos alimentos prejudiciais à saúde. Esquematizamos na figura abaixo, como os estereótipos convencionais atribuídos ao maconheiro como sua pretensa irresponsabilidade, falta de controle e mesmo loucura vão sendo combatidos por racionalizações e justificativas provenientes de um repertório de respostas aprendidas no grupo não convencional de maconheiros experientes.

Figura 29 - Moralidade e Racionalizações

Uso de maconha e controle social - Moralidade

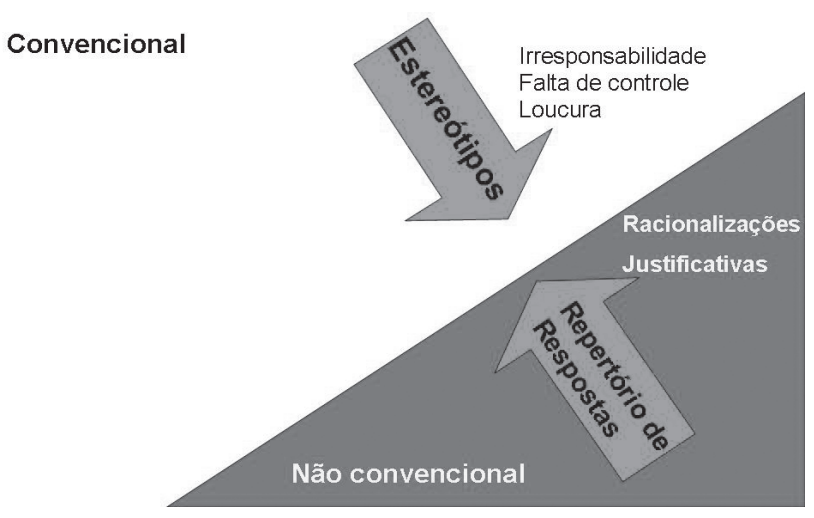

Fonte: Coleção particular do autor.

Infelizmente, falta aos usuários de crack, nossos interlocutores, a possibilidade de construir uma visão positiva a respeito deles mesmos e de sua prática de uso, possivelmente devido 
a avassaladora ideologia do proibicionismo, ou pânico moral em torno do crack. Pelo contrário, eles têm, geralmente, deles mesmos e dos pares à sua volta a visão mais negativa possivel, muito próxima à visão do "Zé Povinho" sobre eles. Fica, portanto, uma situação aparentemente dúbia, os craqueiros desprezam tanto o não usuário preconceituoso quanto o usuário vítima de preconceito, embora em nossa convivência com eles alguns sinais de saída deste estado de "coisas" possam ser vislumbrados.

A primeira delas nos veio pelo depoimento de Corintiano, primo de Mariano e residente na região da Luz há pelo menos uma década. Casado com uma usuária, ele aparenta possuir em torno de 35 anos. Começamos uma conversa em meio à comemoração da festa junina do ano de 2013, realizada na rua Dino Bueno. Primeiramente, conversamos no meio da rua para em seguida, nos dirigimos à calçada para que Corintiano pudesse fazer uso das pedras em seu poder com o mínimo de "radiação". Durante nossa conversa, que durou umas 2 horas, ele foi abordado por diversos usuários pedindo para serem "favorecidos" e propondo as mais diversas "tretas". Corintiano se irritava com tal assédio, mas também participava da "treta" quando ela se mostrava vantajosa. Ao me oferecer para compra, ainda no meio da rua, um interessante cachimbo feito de lâmpada, ele começou a tecer algumas considerações sobre a visão negativa que os não usuários possuíam deles, os craqueiros. "Eles acham que nós somos lixo, né? Se eles vêm um cara caído na rua, ninguém faz nada. Se eu vir um cara caído na rua, eu vou ajudar, não vou tratar ele como lixo. [...] Nós somos a nova Jerusalém."

Corintiano possui certa visão positiva e mesmo superior dele com relação ao "Zé Povinho", pois ele se vê como alguém altruísta e solidário. Quando lhe peço de volta um cachimbo meu, ele me declara: "Eu ia te devolver, porque eu sou homem." Portanto, ser alguém de índole honesta é um valor entre 
os usuários de crack tanto quanto na sociedade abrangente, ao menos nas classes trabalhadora e média ao corresponder em sua conduta com este valor é também fonte de orgulho. Ser honesto também foi uma característica motivo de orgulho para outro usuário, Mariano. Ao conversarmos a respeito de "gente que pilantrava" e que era punida pelos irmãos, Mariano fez questão de nos contar a respeito de casos em que objetos de valor the foram confiados e da maneira correta como ele se comportou. Portanto, nossos interlocutores são perfeitamente capazes de ter também uma visão positiva a respeito de si próprios como seguidores ordeiros da disciplina imposta pelos irmãos e também como pessoas bondosas, altruístas, enfim uma "nova Jerusalém".

Pude observar outras formas de autoimagem positiva nas figuras dos interlocutores Dobem e Zezé, ${ }^{86}$ o primeiro orgulhoso por ser "malandro" e por estar "na responsa" garantindo o "fluxo" na "biqueira". O segundo se sente orgulhoso por deixar seu barraco arrumado, o melhor da "biqueira" a céu aberto e por "brisar na libido", por ter namorada na "biqueira", pela atração que exerce sobre algumas mulheres jovens e bonitas e principalmente, por não ser um "parasita" ou um "nóia", como podemos observar no diálogo abaixo:

Zezé - Olha, desde a hora que cheguei, me alimentei, conversei, arrumei um pouco o barraco [...] Aquilo que havia requisitado que ele estava tomando da mesa, que ele colocou, mais de cinco minutos depois, eu vou fumar. Isso é uma grande diferença entre usuário consciente [...]

Newman interrompe - 'Nóia' sem noção.

Zezé prossegue o raciocínio - [...] E o dependente químico. Zezé - Eu sou dependente, mas num grau diferente. Eu consigo, por exemplo, deixar de fumar e ir fazer uma 'caminhada', fazer outra coisa e depois buscar a droga. Isto porque eu estou virado somente um dia, se tivesse virado dois dias, quando eu cheguei, eu teria que mandar, por quê?

86 Mais à frente descreveremos melhor o usuário Zezé. 
Zezé diferencia o usuário consciente do dependente químico. O primeiro é capaz de dominar sua vontade e cumprir seus afazeres. No decorrer deste livro veremos maiores implicações destas declarações de Zezé. Em Salvador/BA, a antropóloga Luana Malheiros observou algo semelhante com o distanciamento entre "usuários" e "sacizeiros":

O 'sacizeiro' seria o consumidor iniciante, aquele que não consegue regular o uso devido ao pouco tempo de contato com a substância, segundo a classificação de Becker. Seria o indivíduo que tem um uso compulsivo e disfuncional de crack, sem emprego fixo e cuja atividade de trabalho varia de pequenos furtos à mendicância, o que torna a sua estrutura de vida precária. (MALHEIROS, 2012, p. 85)

Seguindo no esquema de Becker, se superar bem, em sua carreira de usuário de maconha, os desafios quanto ao fornecimento da droga, ao sigilo quanto a seu uso e livrar-se dos impedimentos morais a constrangê-lo, o maconheiro poderá finalmente se tornar um usuário controlado. Isto, de modo algum, irá leva-lo ao comportamento estereotipado de estar usando o tempo todo, muito pelo contrário [...] "Seu uso é planejado; considera-o apropriado em certas ocasiões, não em outras". (BECKER, 2008, p. 84) Ele assegura para si mesmo possuir o controle sobre seu uso da droga e isto funciona como símbolo dele desempenhar uma prática inócua. Portanto, não é escravo porque planeja e segue seu plano quanto à quantidade, frequência e oportunidade, com períodos sem o uso da substância psicoativa. Ao reorganizar suas noções morais pode vir a adquirir a concepção de que os valores convencionais sobre drogas não se aplicam ao seu caso, de um uso não excessivo, mas regular. Além de serem sem maiores prejuízos à sua vida, pelo contrário, ele é possibilitador de um fruir cotidiano mais prazeroso e em melhor companhia. Mesmo assim, com o uso regular, questões morais novamente podem reaparecer e o convencimento anterior pode precisar ser reatualizado por testes 
como o abandono do uso por algum tempo, para certificar-se não ser seu padrão corresponde aos da mitologia popular sobre o viciado.

Figura 30 - Uso controlado

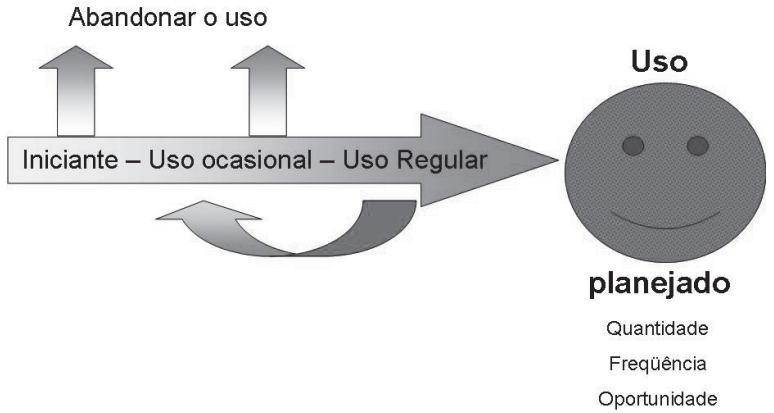

Fonte: Coleção particular do autor.

Um usuário regular pode, portanto, retornar ao uso ocasional e mesmo abandonar o hábito por algum tempo para certificar-se não ser "escravo da droga" como grita o convencionalismo. Sua visão a respeito de seu comportamento como usuário de maconha irá paulatinamente se aproximando da visão compartilhada entre os insiders. Isto se dá na medida de seu distanciamento do modo convencional de considerar esta questão, a dos agora, outsiders. "Em suma, uma pessoa se sentirá livre para usar maconha à medida que passe a considerar as concepções convencionais sobre ela como as ideias mal fundamentadas de outsiders e as substitua pela visão inside que adquiriu por meio de sua experiência com a droga na companhia de outros usuários”.(BECKER, 2008, p. 87)

\section{Além da dependência física e psicológica, a dependência social}

O crack possui uma diferença fundamental com relação à maconha dentro da perspectiva trabalhada por Becker. Ele consi- 
dera a maconha uma droga incapaz de produzir um uso problemático; por isso, seu uso prolongado ocorre na medida do prazer proporcionado por ela. Assim, o maconheiro só irá tornar-se usuário perene caso consiga vencer uma série de etapas em sua carreira e não por ter se tornado "dependente". No caso do crack há o complicador da fissura, inexistente ou pouco presente no uso da maconha. Assim sendo, o uso do crack se mantém, certamente devido ao prazer por ele gerado, mas, também pode prolongar-se ao longo de tentativas sucessivas de se livrar da fissura. Convém-nos ressaltar neste momento a profunda presença de um componente social na manutenção do uso, mesmo em face de consequências deletérias. Ou seja, o prazer por encontrar-se na presença do grupo de usuários, o status alcançado e o prestígio entre os pares, assim como o fascínio pelo ritual de uso são aspectos a serem observados no intuito de considerarmos ao máximo as conexões vividas pelo usuário de crack, passiveis de gerar prazer e mantê-lo em seu hábito. Igualmente, deve-se levar em conta a dificuldade de abandonar esta rotina por ela ter proporcionado um modo de vida no interior do grupo de usuários. No diálogo abaixo, com um ex-usuário de crack da região da Cracolândia paulistana, que atualmente trabalha como orientador socioeducativo com esta mesma população, podemos observar um pouco desta dependência dos vínculos estabelecidos no uso da droga, assim como de certos rituais:

Antônio - Outra, a questão da dependência química que eu achei que era um fator preponderante, não é. É o fator menos importante na oficina. O que eu achei interessante, a partir de um cutucão da minha esposa foi começar a falar nisso. Para desmistificar. O povo pensa: 'É morador em situação de rua, o problema é dependência química'. E não é.

Ygor - E porque que você acha isso?

Antônio - Porque o povo acha isso? 
Ygor - Não, porque você acha que o problema não é a dependência quimica?

Antônio - É um problema social, cara. Tem um recorte de classe aí, também. O problema do morador em situação de rua é o quê? Morador em situação de rua vai existir sempre no nosso sistema.

Ygor - O problema não é a pedra. Qual o problema?

Antônio - Pra ele, pode ser um refúgio, pode ser uma desculpa, pode ser uma alternativa. Às vezes, ele pode estar entediado, mas não é este o fator de ele estar na rua. Briga com a família, desilusão amorosa, migração, baixa escolaridade, desemprego, baixa qualificação, ou não qualificação, não tem qualificação nenhuma. E pra você? O que que você acha?

Ygor - Eu não sei. Eu conversei com as pessoas e todo mundo tem uma história triste para contar. 'Ah, minha família, minha mãe', história de corno, entendeu? Imagina ficar na rua sem fumar pedra?

Antônio - Imagina ficar na rua sem beber pinga!

Ygor - O cara vai fazer o corre atrás da pedra e preenche o tempo, entendeu?

Antônio - Dá motivação. Não, eu falei para você, né? Eu lembro quando eu fui fazer. No meu último tratamento. Foi um tratamento um pouco mais técnico que mexeu com a minha parte psicológica. Nunca havia olhado para isso. Eu comecei a perceber através de terapia que as relações que eu tinha através de droga, a parceria, o 'corre', como preparar o negócio. Tudo isso tinha tanta força quanto o crack.

Ygor - Claro. O ritual é sensacional.

Antônio - Porque eu falo para você. Sandra (esposa), eu não lembro da 'brisa' faz muito tempo, mas eu lembro disso e parece que me dá prazer de lembrar. Quando eu subia o escadão de Santos pra buscar droga, eu lembro. Quando eu ficava pra trocar uma ideia com os caras, eu lembro. Quando eu ia junto com uma mina fumar droga, eu lembro.

Ygor - Do 'corre', da 'sintonia'[...]

Antônio - Tudo, maravilha. Porra cara! O livro 'Prevenção da recaida' fala dessas relações que se tem com a droga, que tem que colocar as pessoas em outras relações. Ba- 
seado também em Narcóticos Anônimos (NA), ${ }^{87}$ 'Lugares, hábitos e pessoas'.

Ygor - Só por hoje.

Como brilhantemente observou Timothy Leary: “O usuário é viciado não apenas na droga, mas também no ritual da procura. Em vários casos, obtê-la é a absorvente aventura de um dia inteiro para pessoas que, de outra forma, estariam entediadas ou frustradas com a vida". (LEARY, 1999, p. 432)

Antônio, nosso interlocutor, abre com suas observações uma nova perspectiva na análise do abuso de drogas e particularmente, do crack para além das observações de Becker sobre a importância das interações pessoais no aprendizado das técnicas de uso, percepção dos efeitos e sua significação como prazerosos. Todo este suporte grupal possibilita o uso bem sucedido da maconha por prazer é profundamente importante e sem ele, segundo o modelo de Becker, este uso prazeroso seria em muito dificultado. Porém, outra escala de importância do grupo, ou grupos de usuários com quem o craqueiro terá contato em sua carreira, surge ao levarmos em conta o depoimento de Antônio e nossas observações de campo.

$\mathrm{Na}$ oficina de futebol oferecida por Antônio como seu trabalho socioeducativo ligado a Centros de Convivência conveniados com a Prefeitura Municipal de São Paulo, o uso do crack não lhe aparece como o determinante da situação de rua, na qual os participantes da oficina se encontram. A chamada "dependência química", ou dependência de substância como consta do Diagnostic and Statistical Manual of Mental Disorders (DSM-IV) ${ }^{88}$ (KAY; TASMAN; LIEBERMAN, 2002) não é o dado mais significativo dos participantes das oficinas de futebol e sequer dos moradores de rua, segundo este educa-

87 Narcóticos Anônimos

88 A última versão do DSM, de $n^{\circ}$. V, traz o conceito de transtorno por uso de substância. 
dor, ele mesmo ex-usuário de crack e ex-morador de rua na região da Cracolândia paulistana. Esta opinião é compartilhada por sua esposa, também ela com larga experiência no trabalho com esta população e na mesma região central da cidade. Em nossas observações de campo, participamos de diversas rodas de crack e descrevo abaixo, um dos barracos por nós frequentado e as motivações de Zezé, seu dono, para encontrar-se em situação de rua fazendo uso cotidiano de crack. O trecho abaixo foi retirado do caderno de campo de fevereiro de 2013

Um pequeno móvel aparentando ser um armário de banheiro com espelho e contando com uns $40 \times 30 \mathrm{~cm}$ encontrava-se no chão, mais ou menos no meio do barraco. Era o único item de mobiliário e estava destinado ao preparo do crack e ao depósito das pedras disponiveis para uso dando também suporte aos aparelhos, ferramentas e demais componentes da parafernália de usuário. Às vezes, este pequeno armário era aberto, mas não se costumava guardar muita coisa em seu interior, preferindo-se manter os objetos à mostra. Duas revistas eróticas circulavam pelo barraco, servindo como suporte para o preparo das misturas de crack com cinza, antes de serem colocadas no cachimbo para uso. Tanto homens quanto mulheres usavam as revistas como base. O dono do barraco era um carioca, entre 45 e 50 anos de idade, ele nos declarou ser artista plástico, produtor de peças que serviam de base para confecção dos moldes utilizados na produção em série de estatuetas. Também fez fontes de água em pousadas e diz ter tido empresa, 'maquinário' e funcionários. Tentou suicídio duas vezes. Cometeu o assassinato de seu ex-cunhado após este estuprar sua irmã, engravidá-la e fugir para a região nordeste do país. Aos 12 anos, saiu no encalço do estuprador para encontrá-lo; aprendeu a viver na rua até poder efetuar sua execução com uma pedrada na cabeça. A primeira tentativa de suicidio veio após ser agredido pelo sobrinho, filho do estuprador por ele assassinado. Este sobrinho foi motivado pelo conhecimento das condições da morte do pai, estuprador da própria mãe. A segunda tentativa de suicídio veio após retornar de uma das viagens para confecção e instalação de fontes para 
piscina em pousadas. Ele costumava hospedar-se nestas pousadas enquanto realizava o serviço, uma condição para ele muito agradável. Ao retornar de uma destas viagens a trabalho encontrou sua esposa vivendo com outro homem e seu negócio, com 'maquinário', galpão e funcionários desfeito e vendido pela esposa traidora em conluio com o irmão dele. Pulou em tentativa de suicídio de altura de 10 metros tendo de passar vários meses internado. Ao sair não recebeu apoio familiar algum e entrou em depressão. Chegando à rua foi trabalhar em reciclagem. 'Desisti e aqui encontrei um meio de coexistir'.

Todos na rua têm seu "vulgo", aqui usaremos o vulgo do vulgo para nos referir novamente ao nosso interlocutor cuja história foi brevemente resumida acima e o chamamos de Zezé. Ele fala de modo calmo, educado e extremamente articulado; não possui gestos bruscos ou violentos, fala sobre si e sobre "quem fuma crack" e orgulha-se de ter dado vulgo a muita gente. Como meu nome é de origem russa, Zezé, um dia, propôs vodca como meu vulgo.

Vejamos, portanto, a história de Zezé juntamente com as considerações de Antônio sobre o morador de rua. Como vimos, Zezé aprendeu a viver na rua aos 12 anos de idade em uma situação particularmente traumática e fora de sua cidade. Havia viajado para localizar e assassinar o estuprador de sua irmã e pai de seu sobrinho. Consumado o assassinato, uma série de infortúnios o levou a duas tentativas de suicídio, tendo a segunda tentativa o deixado particularmente vulnerável após longa internação. Abandonado pela família e com os negócios destruídos pela esposa infiel encontrou na vida na rua, organizada em torno do consumo do crack, um local para "coexistir". Portanto, o uso da pedra de crack proporcionou um ambiente social propício a acolher Zezé. Após duas tentativas de suicídio e não possuindo mais sua fonte de sustento e tão pouco apoio familiar, mesmo porque com o fato dele ser o assassino do cunhado, pai de seu sobrinho, certas portas se fecharam na família. Elas se tornaram ainda mais cerradas pela traição 
cometida pela esposa e pela perda das fontes de renda. Assim sendo, o cotidiano fornecido pelo uso em grupo do crack preenche o espaço diário de atividades com a busca por meios para sustentar o consumo da droga, as relações afetuosas com mulheres, conforme visto em momento anterior deste trabalho, no "corre", na "treta", na manutenção a todo instante do barraco, em conversas e numa grande gama de atividades condizentes com a situação de rua. Se quisermos usar jargões correntes da psiquiatria, como o de dependência química, ou dependência de substância, poderíamos também sugerir a existência de uma dependência social de todas estas relações, vínculos e práticas proporcionadas pelo uso do crack.

Assim sendo, as observações de Antônio sobre suas recordações saudosas de muitas das atividades concernentes ao uso de crack no centro de São Paulo e na cidade litorânea de Santos, tomam outra feição. Ao afirmar serem as "relações" advindas do uso do crack o elo mais forte com o uso, ainda remanescente após uma década de abstinência, ele nos revela a força das diversas conexões estabelecidas a partir da droga e nos leva a pensar para muito além de seus estritos efeitos: "a parceria, o 'corre', como preparar o negócio. Tudo isso tinha tanta força quanto o crack". Dependência social vinculada ao uso de drogas e particularmente ao uso do crack está ligada a importância do ritual na vida humana. Ao acostumar-se a um ritual, o usuário tende a desejar repeti-lo, principalmente ao se tratar de um ritual prazeroso associado a um consumo recreativo de drogas, também ele em si proporcionador de prazer. Devemos dar a devida atenção ao fato de que "preparar o negócio" dá prazer.

Como vimos nas observações de Timothy Leary a respeito de como o esforço desprendido para se obter a droga faz parte do uso, usar uma droga é também envolver-se no mundo das drogas, com pessoas usuárias e traficantes de drogas; é partilhar de suas preocupações, de seu cotidiano. Isto claramente 
Jamais fomos zumbis

deixa lembranças e faz parte da totalidade do uso, como muito bem observou Antônio:

Antônio - Eu não lembro da 'brisa' faz muito tempo, mas eu lembro disso e parece que me dá prazer de lembrar. Quando eu subia o escadão de Santos pra buscar droga, eu lembro. Quando eu ficava pra trocar uma ideia com os caras, eu lembro. Quando eu ia junto com uma mina fumar droga, eu lembro.

Assim, podemos realmente separar o prazer das amizades, da companhia, dos relacionamentos amorosos, dos flertes entre usuários tantas vezes por nós testemunhados nos locais de uso, dos efeitos do crack? A recorrência no uso teria muito a ver com certa "fissura da rua" (GREGIS, 2002), fissura, neste sentido que vai muito além de se procurar "evitar o desconforto da privação”. (KAY; TASMAN; LIEBERMAN, 2002) Se analisarmos as definições consagradas de dependência química veremos como a dependência social preenche uma lacuna de interpretação do uso de drogas e abre novas possibilidades para sua compreensão.

Segundo definição da Organização Mundial da Saúde (OMS) a dependência química é:

[...] [o] estado psíquico e algumas vezes físico resultante da interação entre um organismo vivo e uma substância, caracterizado por modificações de comportamento e outras reações que sempre incluem o impulso a utilizar a substância de modo contínuo ou periódico com a finalidade de experimentar seus efeitos psíquicos e, algumas vezes, de evitar o desconforto da privação. (FIDALGO; NETO; SILVEIRA, 2012, p. 2)

Pela perspectiva adotada até agora, fica claro como o encontro entre o organismo vivo humano e a substância dá-se em um contexto social capaz de conferir propósito a este uso. Todos os outros fatores levantados acima, como o aprendizado que torna possivel sentir os efeitos e lhes dar significação positiva; 
o grupo de pares que proporciona um repertório de justificativas para o uso e meios para obtenção da droga. Somados são a um grupo onde o uso não seja mal visto e dentro do qual se possa gozar dos efeitos da droga em companhia de outros usuários.

Interessa-nos ressaltar neste momento, dentro da definição de dependência química "o impulso a utilizar a substância de modo contínuo ou periódico". (FIDALGO; NETO; SILVEIRA, 2012, p. 2) Este impulso, por outros chamado de compulsão, seria o dado propriamente psicológico da dependência segundo o discurso estabelecido a respeito da dependência de substância. A dependência teria um aspecto físico e outro psicológico. $\mathrm{O}$ contexto social ficaria restrito, por exemplo, aos itens $\mathrm{V}$ e VI da DSM-IV, como o tempo "gasto em atividades necessárias para obtenção da substância" e na "utilização da substância ou na recuperação de seus efeitos", assim como no fato de que também "importantes atividades sociais, ocupacionais ou recreativas são abandonadas ou reduzidas devido ao uso de substâncias". (KAY; TASMAN; LIEBERMAN, 2002, p. 190)

Portanto, como vimos acima, o contexto social é relegado pela DSM-IV às atividades de obtenção, uso e "recuperação" dos efeitos da droga. ${ }^{89}$ Contudo, vimos como o ritual de uso e o companheirismo entre os usuários são fundamentais para compreender a atração exercida pelo contexto social sobre os usuários de crack. Este contexto também é atraente por fornecer um meio seguro para se usar a droga e se evitar as sanções das pessoas valorizadas pelos usuários de crack. É um porto seguro e de certa forma aconchegante de pares com interesses em comum em torno da droga, com uma visão, se não positiva, ao menos tolerante e dotada de valores com os quais se podem identificar e obter a satisfação e valorização negadas pela sociedade abrangente e contaminada pela ideologia do proibicionismo, ou pânico moral.

89 Pouco se alterará no DSM-V esta visão restrita do contexto social. 


\section{Norman E. Zinberg e a importância do setting no uso de drogas}

Duas décadas após a publicação do trabalho seminal de Howard Becker, Norman E. Zinberg publica uma pesquisa absolutamente fundamental para a compreensão da questão do uso de drogas sob uma perspectiva social. Drug, set, and setting: the basis for controlled intoxicant use foi publicado no ano de 1984, pela Yale University Press. A obra foi baseada em investigação realizada após mais de 20 anos de experiência clínica do autor, médico e professor de psiquiatria clínica na Universidade de Harvard. Ele procurou saber como e porque muitos usuários, frente a outros que faziam uso descontrolado, conseguiram conquistar e manter o controle sobre o uso de certas drogas. O setting, ou contexto de uso, passou a ganhar importância de certa forma por acaso, ao se perceber que a atitude dos médicos influenciava o efeito que as drogas por eles prescritas tinham nos seus pacientes. Em 1968, Zinberg pôde, através de uma bolsa, estudar o sistema britânico de terapia de manutenção de heroína e encontrar lá, dois tipos de adictos, ambos diferentes do americano. O primeiro, que funcionava adequadamente até mesmo com sucesso e o segundo, ainda mais debilitado que o viciado norte americano, porém, como o alcoólatra americano, não era causa de apreensão, criminalidade ou histeria pública. Estas diferenças entre países puderam aos poucos ser atribuídas aos diferentes settings sociais e às diferentes atitudes sociais e legais com relação ao uso de drogas e aos usuários. Na Inglaterra, o uso de heroína não era crime e os adictos podiam ser legalmente supridos, estavam livres das restrições legais e de boa parte do estigma. Isso lhes dava a possibilidade de escolher entre aceitar o uso de drogas como fato e manter suas atividades rotineiras, ou verem-se como anormais e adotarem um estilo de vida destrutivo. Tornava-se claro que não seria mais possivel, para entender a experiência com a droga, limitar-se a farmacologia (drug) e a personalidade do usuário (set), mas 
também deveria-se atentar ao ambiente (setting) físico e social em que o uso ocorre.

Ao se debruçar sobre o problema do abuso de drogas entre alistados no Vietnam, Zinberg pôde perceber que o uso pesado de heroina entre as tropas, assim como outras atitudes, estava ligado à atração exercida por atividades que apagassem o mundo externo. O setting proporcionado pela guerra não permitia que rituais e sanções sociais de controle tivessem chance de se desenvolver, isto dificultava muito o uso controlado. Porém, assim que os abusadores foram retirados do ambiente nocivo, o abuso virtualmente cessou. Ao prosseguir suas pesquisas com usuários de heroína, Zinberg percebeu a existência de numerosos padrões de uso, como usuários de final de semana e mesmo usuários ocasionais de longa duração.

Era amplamente difundido no século XX, a ideia de ser a heroina comumente procurada por pessoas com profunda desordem de personalidade e que para elas, a abstinência total se tornara a única alternativa. Estudos dos anos 1960 do século passado igualavam uso a abuso e raramente consideravam o uso moderado ou ocasional como um padrão viável. O uso não abusivo era tratado como um estágio de transição breve rumo à abstinência, ou, mais comumente, ao uso compulsivo. Os pesquisadores da época e em grande medida até os dias de hoje, procuravam primeiro determinar os potenciais efeitos danosos das drogas ilícitas para então, estudar as desordens de personalidade resultantes do uso destas substâncias. Desordens que eram, ironicamente, consideradas responsáveis pelo uso de drogas. Howard Becker criticou esta abordagem psicológica em sua pesquisa com usuários de maconha. Mesmo antes dos anos 1960, sabia-se que para entender como o controle de uma substância colocada no corpo poderia ser desenvolvido, mantido, ou perdido, diferentes padrões de consumo teriam de ser comparados. A esta tarefa dedicou-se Zinberg nos EUA e Inglaterra, no Brasil, os estudos desenvolvidos, entre outros, por 
Edward MacRae e Júlio Simões com usuários de maconha, por Osvaldo Fernandez entre os inaladores de cocaína e por Luana Malheiros entre os usuários de crack, também caminham nesta mesma direção.

Estudos sobre o consumo de maconha, como os levados à frente por Becker e realizados na segunda metade do século $\mathrm{XX}$, nos EUA, provaram que as antigas considerações sobre seus alegados malefícios à saúde eram sem fundamento. A maior parte dos usuários desenvolvia um padrão ocasional e moderado mais que intensivo e crônico. Uma pesquisa sobre os veteranos do Vietnam (ZINBERG, 1984, p. 12) indicou que o consumo de heroína (tida então como a mais perigosa das drogas) nem sempre levava à adicção ou uso disfuncional e, mesmo quando ocorria, a adicção era mais reversivel do que se costumava acreditar. Aparentemente, assim como a crença de que drogas ilícitas eram todas danosas estava perdendo terreno, a crença de que a maioria das substâncias lícitas, como café, açúcar, tabaco e aditivos de alimentos eram todos benignos, também estava. Zinberg sustentou que para entender o que impele alguém a utilizar uma droga ilícita e como esta droga afeta o usuário, três determinantes devem ser considerados de modo interligado: a droga (a ação farmacológica da própria substância), o set (a atitude da pessoa quando do uso, incluindo sua estrutura de personalidade e seu propósito de uso) e setting (a influência do meio, do contexto físico e social em que ocorre o uso). Dos três determinantes, o setting era o que recebia menor atenção, no entanto, tornou-se o foco da sua investigação. Assim, detectou-se que o setting social, através do desenvolvimento de sanções e rituais, possui a capacidade de manter o uso de drogas ilícitas sob controle.

$\mathrm{O}$ uso de qualquer droga envolve valores e regras de conduta (que foram chamados de "sanções sociais") e padrões de comportamento (que foram chamados de "rituais sociais"); estes dois juntos foram designados os "controles sociais infor- 
mais". As sanções sociais definem "se" e "como" uma droga em particular deve ser usada. Elas podem ser informais e compartilhadas por um grupo, como nas máximas associadas ao consumo de álcool: "não misture bebida fermentada com destilada., ou podem ser formais, como nas leis e politicas dedicadas a regular o uso de drogas: "se beber, não dirija". Vemos aqui, portanto, um desdobramento e sofisticação do modelo de Howard Becker analisado por nós anteriormente. Para ele, as sanções sociais ocorrem preferencialmente no âmbito daquilo que ele chama de sociedade abrangente, ou a partir dos não usuários, cabendo aos usuários exercerem alguma sanção no caso da necessidade do neófito passar a dispor de seu próprio suprimento de maconha após seu uso tornar-se um pouco mais constante. Zinberg traz as sanções sociais mais para dentro do grupo de usuários (valores e regras de conduta) e mostra sua importância para a regulação do padrão de uso, assim como leva, ao mesmo tempo, em consideração a importância do ritual (padrões de comportamento).

Corintiano, nosso interlocutor na Cracolândia, entre outros, nos disse a seguinte frase que pode ser entendida como uma máxima entre os usuários por nós contatados: "Você deve saber usar para não ser usado". No caso soteropolitano estudado por Luana Malheiros (2012), a representação do usuário descontrolado cai sobre a figura do "sacizeiro" e isto fica claro no depoimento da usuária Vanessa:

[...] aquele que você reconhece logo; não consegue esconder que fumou crack. Não [es]tá acostumado com a onda e fica no pânico; você reconhece fácil um 'sacizeiro', ele não faz questão de se esconder. Fuma na frente de todo mundo, fica no pânico, não se controla, quer usar toda hora, quando tem a pedra, não quer dividir, é guloso, vive sujo, fedido... Por uma pedra de crack, é capaz de fazer qualquer covardia, não pensa no dia seguinte, só pensa na droga. (MALHEIROS, 2012, p. 85) 
Figura 31 - Sanções sociais

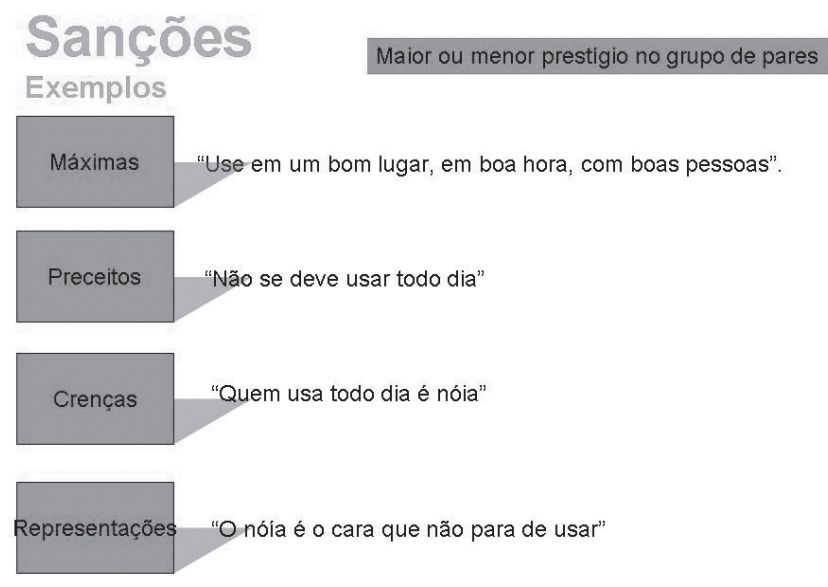

Fonte: Coleção particular do autor.

Os rituais têm relação com os métodos de obter e administrar a droga, a seleção do meio físico e social para uso, as atividades desenvolvidas após a administração da droga e os modos de prevenir os efeitos indesejados. Eles ainda servem para apoiar, reforçar e simbolizar as sanções, colocando-as em relação direta com as pessoas através da prática. Podemos afirmar também, para além de Zinberg, que os rituais fazem mais que relacionar sanções sociais e seus membros. Radcliffe-Brown em seu aclamado livro The Andaman Islanders, de 1922, procurou testar as hipóteses de Durkheim sobre a função dos rituais como a expressão de sentimentos coletivos de uma sociedade; contribuindo para sua coesão e manutenção. Neste sentido, os rituais seriam práticas destinadas a consolidar, ou mesmo sustentar e produzir um sistema de crenças. Porém, em escritos tardios, ele irá defender que os rituais expressam mais que a dependência humana da sociedade; os rituais expressariam, então, a dependência tanto ao contexto físico quanto social. Eles seriam essencialmente expressivos, através de uma maneira de dizer algo além de fazer. A chama- 
da escola de Manchester, da antropologia social inglesa, foi um dos mais importantes frutos desta tradição. Um de seus membros, Victor Turner, dedicou parte de sua obra ao estudo do ritual e nele viu um local de produção de alternativas voltadas, ou não, à manutenção do status quo. Assim, a antiestrutura, estados liminares e potenciais da sociedade, pode ser atualizada e levar à transformação ao expor as alternativas possiveis de destino no drama social. Veremos mais à frente, como a ideia de "communitas" de Victor Turner pode nos auxiliar a compreender a atração exercida pelo contexto social sobre os usuários de crack.

Figura 32 - Rituais, algumas características e interpretações
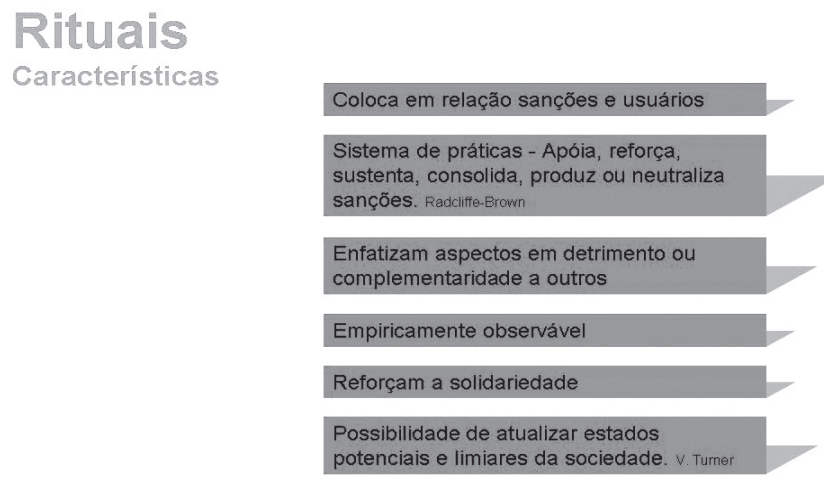

Fonte: Coleção particular do autor.

No caso do álcool, por exemplo, o convite "Vamos tomar uma cerveja" automaticamente coloca algum grau de controle por usar o termo singular "uma cerveja". Por contraste, "Vamos encher a cara" implica que todas as restrições serão abandonadas. Isto exemplifica, uma forma de sanção social por meio de máximas. No segundo caso, mais precisamente, a ausência de sanção ao abuso, ou ainda, uma sanção ao uso moderado da bebida alcoólica. 
Um ambiente propício para pensarmos a relação entre rituais e consumo de álcool são os torneios esportivos universitários, onde se misturam festas, esportes e viagens. As diferentes instituições de ensino rivais possuem suas equipes e respectivas torcidas; faz parte da identidade de certas torcidas ser aquela mais disposta a "aloprar", ou "causar", ou seja, "perder a noção do limite" e "[...] fazer coisas inimagináveis em qualquer momento". (COSTA, 2009, p. 26) Além das festas com quantidades consideráveis de bebida, jogos e brincadeiras são elaborados com a finalidade de se consumir grandes quantidades de álcool, tais como o feitio do "cajuzinho" por um centro acadêmico, a "maratona" da pinga e o campeonato de "bola beque". Uma das variantes do "cajuzinho" foi assim descrita:

[...] a torcida que estava na piscina mobilizou-se para dentro do ginásio transportando os instrumentos da bateria, as bandeiras e um tonel com capacidade para 200 litros, ao qual tinham adaptado uma pequena torneira próxima ao fundo. Quando todos estavam em posição, com o tonel colocado no centro da bateria, começaram a trazer caixas. Havia cerca de cinco ou seis rapazes e cada um transportou pelo menos duas delas, que continham oito garrafas de plástico de $600 \mathrm{ml}$ de pinga cada uma. Conforme eram trazidas, as caixas eram destruídas com certo alvoroço e empolgação e as garrafas distribuídas para a torcida que despejava o conteúdo no tonel. Todos queriam participar conjuntamente do preparo, afinal, o cajuzinho, mais do que uma bebida, é uma forma de estabelecer a união entre os alunos da USP São Carlos. Depois de pronto, bastava colocar a caneca, copo ou garrafa embaixo da torneira e beber o 'suco mágico' do Caaso. ${ }^{90}$ (COSTA, 2009, p. 26, grifo nosso)

A "maratona" corresponde a uma corrida que possui no decorrer do percurso, diversos pontos de parada onde os competidores devem consumir bebida alcoólica, geralmente pinga.

90 Centro Acadêmico Armando Salles de Oliveira. 
Ganha a corrida o competidor mais rápido, mas também o mais resistente à ingestão de bebida em grandes quantidades. No campeonato de "bola beque", ganha o competidor capaz de enrolar e acender um cigarro de maconha no menor tempo. Portanto, consumir bebidas alcoólicas, principalmente a cerveja, faz parte de certo ethos festivo compartilhado pelos estudantes, a partir do qual "se compartilha bebida e são estabelecidas as relações sexuais”. (COSTA, 2009) As competições chegam a reunir 15 mil participantes e o consumo de bebida alcoólica pode chegar a 7 mil caixas de cerveja e 500 de vodca.

Repare que servir os participantes em suas próprias ca-
necas é uma maneira de dividir o que está sendo bebido;
a festa é o momento de partilhar, de trocar e através da
bebida as pessoas estão em relação. A intensidade com
que são consumidas substâncias durante as festas in-
dica essa aproximação; conhecer estudantes de outros
lugares, reencontrar antigos amigos ou mesmo a paquera
é transpassada pelo consumo de bebidas alcoólicas, pois
elas estabelecem uma relação. (COSTA, 2009, p. 37)

Vemos aqui, portanto, como os rituais em torno do consumo de álcool e maconha são importantes na definição dos padrões de consumo destas drogas exibidos por estudantes universitários em seus encontros esportivos. O ritual de beberem juntos, em um clima festivo e competitivo; de compartilharem a mesma bebida feita conjuntamente como o "cajuzinho", completando suas canecas sob a mesma torneira, tudo isto contribui para estabelecer um sentimento de união em torno da bebida compartilhada. Ao mesmo tempo incentiva a beber mais, dado que a bebida os coloca em relação e relacionar-se, sexualmente ou não, com o maior número de pessoas é um dos objetivos destes encontros. A "maratona" é um evento de competição em torno do consumo do álcool, no qual beber grandes quantidades de pinga e resistir fazem o vencedor; ser bem-sucedido neste evento competitivo torna vitorioso não apenas a pessoa, mas o grupo de estudantes 
por ela representado na contenda. Isto posto, vemos como o ritual pode influenciar profundamente o padrão de consumo de álcool nestas ocasiões. Portanto, levar em consideração a ocasião de consumo é de imensa importância e está presente no interior das ideias de Zinberg, correspondendo ao setting de uso. Podemos visualizar esquematicamente como se desenha o setting, segundo Zinberg, da maneira abaixo:

Figura 33 - Contexto físico e social do uso controlado de drogas

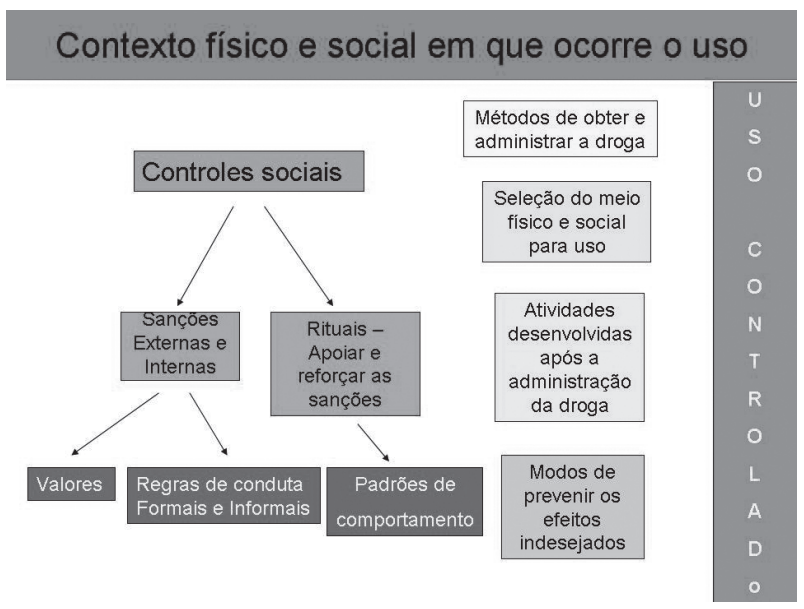

Fonte: Coleção particular do autor.

Controles sociais (rituais e sanções) se aplicam ao uso de todas as drogas, não apenas ao álcool e operam em uma gama de settings sociais, variando muito dos grupos sociais abrangentes, representativos de uma cultura como um todo, até um pequeno e discreto grupo. Mas, sanções e rituais tendem a ser mais diversificados quanto mais próximos às circunstâncias. Por exemplo, no uso de drogas injetáveis, não aplicar a droga até que a última pessoa tenha chegado e as portas estejam fechadas. É importante ressaltar que nada garante que as san- 
ções e rituais se desenvolverão como mecanismos de controle de doenças (como o ritual de puxar sangue para dentro da seringa com heroína para em seguida injetá-lo).

Como vimos a partir das ideias de Becker, o grupo de usuários de drogas ilícitas é capaz de fornecer toda uma série de argumentos favoráveis ao seu uso, a despeito da proibição formal. Contudo, os conflitos com a lei, engendrados pela proibição formal, podem causar ansiedade ao usuário e interferir no uso controlado. Pois, na tentativa de lidar com o conflito com a lei, o usuário pode demonstrar mais bravatas, exibicionismo, paranoia, ou sentimentos antissociais do que se estivesse bebendo num bar, ao lado de uma sala de concerto. Este é o tipo de conflito que faz do controle social das drogas ilícitas mais complexo e mais dificil de conseguir que o uso controlado de drogas lícitas.

A paranoia entre usuários de crack é tão marcante quanto a "nóia", e tornou-se sinônimo de craqueiro; comportamentos como olhar insistentemente por um buraco de fechadura, ficar em silêncio procurando escutar algum barulho e andar pelas ruas com ar desconfiado são considerados típicos. Porém, este comportamento não é bem visto pelos demais usuários e no uso coletivo do crack, "os usuários considerados como os mais paranoicos acabam sendo afastados do grupo". (OLIVEIRA, 2007, p. 119)

Vimos neste livro, como existe um ethos subjacente ao uso do crack; nele, a "sintonia" é o sentimento positivo e a radiação, o negativo. A "sintonia" é o sentimento de confiança e empatia entre usuários partilhando a mesma droga, o contexto favorável à "brisa" deleitosa, uma agradável sensação de paz, segurança e comunhão. A "radiação" é seu inverso. Uma "brisa horrenda, medonha" também tem o poder de trazer "radiação", pode "arrastar", ou contaminar todo um grupo e mesmo gerar "aproximação", ou seja, expor aquelas pessoas, chamar 
a atenção sobre elas. Enfim, uma performance desfavorável "Rouba a 'brisa' do outro", como nos declarou o ex-usuário Antônio.

Antônio também nos descreveu um ritual de uso do crack que se dava da seguinte forma. Em um quarto de imóvel abandonado na cidade de Sorocaba/SP, um grupo de aproximadamente seis usuários de crack se juntou para fazer uso coletivo da droga. Todos possuíam uma quantidade razoável de pedras, mas não exatamente a mesma quantidade e um dos participantes não tinha quase nenhum crack. Decidiram fazer o uso em conjunto, portanto, não se preocupando com pequenas frações de pedra que poderiam perder ou ganhar se usassem sozinhos, ou se evitassem usar com este ou aquele participante da roda. Fundamentalmente, o mais importante era permanecerem juntos, usar conjuntamente e em "sintonia". Desfrutar do prazer da companhia reciproca proporcionada pelo consumo de crack, como a bebida para os universitários, no caso dos jogos, o crack coloca pessoas em relação. Como um dos usuários praticamente não possuía pedras para fumar, ele imediatamente assumiu a função de "contenção", ou seja, passou a providenciar água para a roda de fumantes e a servir os "tragos" nos cachimbos. Isto se deu da seguinte forma: seguindo o sentido horário da roda, o "contenção" passa a pedir o cachimbo dos usuários, a começar pelo imediatamente à sua esquerda e, sobre o alumínio perfurado do "boris", prepara um "trago" depositando sobre ele certa quantidade de cinza e depois, uma fração de pedra de crack. O tamanho da fração da pedra depositada no cachimbo dá a dimensão do "trago" a ser sorvido pelo craqueiro. Portanto, é de interesse do craqueiro ter um "trago" condizente com sua vontade de fumar naquele momento, o que não significa necessariamente, o maior pedaço de pedra possivel. 
Figura 34 - Ritual de uso do crack

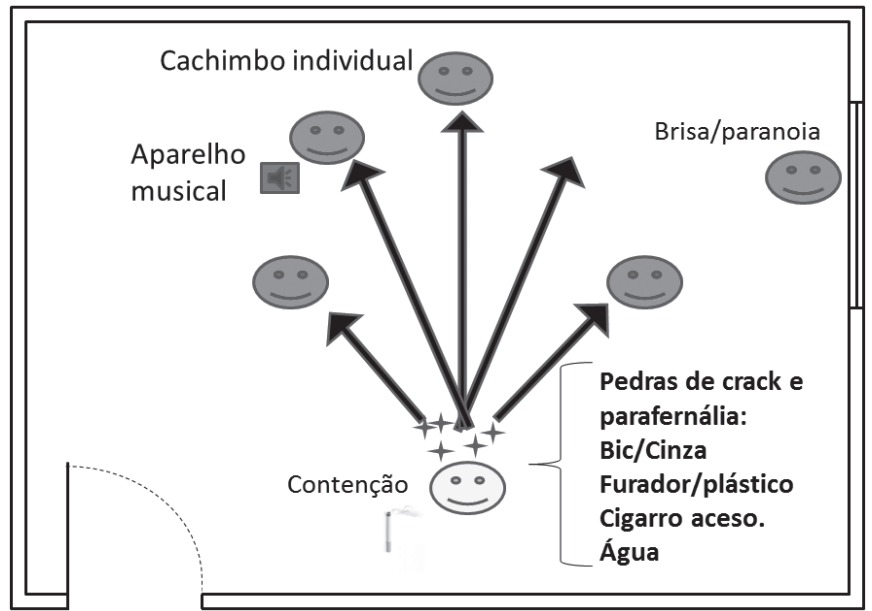

Fonte: Coleção particular do autor.

Vemos, portanto, que o “contenção" desempenha papel importante na roda e é dele também a responsabilidade por servir todos os outros componentes, mesmo estando um deles afastado momentaneamente, por motivo de alguma paranoia qualquer. Antônio nos descreveu certo comportamento de ir até às janelas do imóvel abandonado para respirar um pouco e esperar passar uma "brisa" mais forte, que porventura tenha se abatido sobre algum usuário. Ele poderá estar seguro de que, quando retornar à roda, seu "trago" estará à sua disposição, sem que ninguém venha a "meter o louco", ou seja, tomar vantagem indevida sobre o usuário ausente. $\mathrm{O}$ "contenção" também se responsabiliza por manter sempre um cigarro aceso para proporcionar cinza constante aos cachimbos, assim como pode ajustar o cachimbo de alguém, ou retirar a preciosa "rapa" para novos "tragos".

Há uma série de valores a permear o uso do crack, todos já abordados anteriormente, como: a reciprocidade, o movimento, 
a "sintonia", a honestidade, a confiança e a cordialidade. Quando alguém é "favorecido", ou seja, quando lhe fazem algum favor, ou the fornecem algum bem, como um dos componentes da parafernália, se espera retribuição posterior. A própria "treta" ou troca generalizada de bens e serviços, tem como base a equivalência e o consumo perene da pedra. Assim como as relações necessárias à fruição do crack em um ambiente de uso coletivo dependem de se saber retribuir na justa medida. O "parasita", como visto antes, é a pessoa acusada de imobilismo em um ambiente de uso. Lá, todos devem fazer seu "corre", ou seja, ir atrás dos meios para permanecer no circuito da "treta" e poder usar crack, de preferência em "sintonia" com seus "parças". Portanto, a "sintonia", além de um sentimento de fraternidade entre pares, é também um valor que se contrapõe à "radiação" ou discórdia. Por fim, a cordialidade é o modo preferencial de comportamento entre usuários de crack. O contrário disto seria "meter o loco", ou tratar os demais usuários com desrespeito em um ambiente de iguais e conhecidos muitas vezes de longa data.

O usuário Mariano, de quem tratamos antes, nos contou histórias de frequentadores da Cracolândia que gastaram uma quantidade razoável de dinheiro, um ou dois mil reais, em poucas horas de uso do crack, ficando sem fundos para continuar a "favorecer" seus "parças". Estas histórias exemplares nos mostram a importância de se observar a máxima entre os usuários de crack, de "usar, sem ser usado".

No ritual descrito por Antônio observamos como é importante a "sintonia", a confiança e a honestidade entre usuários em uma roda de crack. Ela também não poderia se manter sem uma grande dose de cordialidade entre seus frequentadores, cordialidade esta que pudemos observar inúmeras vezes, sempre que frequentamos um fumódromo ou a Cracolândia. Para manter a "sintonia", não se pode querer fumar mais que os outros, ou desejar fumar ininterruptamente na roda de crack. 
É fundamental saber aguardar sua vez, esperar, dar-se ao respeito para não ser descortês, nem trazer "radiação" e "roubar a brisa" de alguém.

Podemos, portanto, afirmar que existem valores entre os usuários de crack, nos contextos de uso objeto desta pesquisa, que contribuem para o autocontrole. Um usuário que gaste todo seu dinheiro, ou bens no circuito da "treta" de modo pródigo estará o tempo todo demandando "favorecimentos" por parte dos demais frequentadores do local. Contudo, após, durante e anteriormente ao uso do crack, os usuários estão imersos no circuito da "treta" e para tanto, fazem seus "corres". Tais atividades podem demandar uma maior disponibilidade de pedras, como descrito anteriormente por Zezé. Para seguir em uma "caminhada", em busca de fundos para prosseguir no uso e suprir suas demais necessidades, o usuário se vê na desconfortável situação de ter de fumar para se manter acordado; não para ter "brisa" e tão pouco por prazer. Neste sentido, a situação de rua e o modo como se obtêm fundos joga contra um maior controle no uso do crack. É preciso se manter acordado, em movimento e, ao mesmo tempo, é dificil dormir confortavelmente na rua. Portanto, o usuário de crack, nos ambientes por nós frequentados em nossa pesquisa, tende a desenvolver um padrão de uso por vezes semelhante ao binge, ou seja, um uso até o esgotamento de suas forças. Embora existam pressões, como as exibidas acima, para a moderação, a dinâmica entre estas duas tendências se mostra complexa por relacionar forças distintas em ação constante na "caminhada" de cada usuário.

Mesmo com um padrão de uso muitas vezes semelhante ao binge, devemos considerar que até os mais afetados alcoolistas e adictos, que poderiam ser agrupados no fim do espectro de uso de drogas, exibem algum controle sobre si e sobre seu uso. Eles efetivamente fazem determinadas escolhas sobre se irão usar ou não, em qual momento, com quem e quanto usarão. Observamos isto por diversas vezes no campo com usuários de crack 
que, por exemplo, guardam pedaços de sua pedra para consumir em ocasião mais oportuna. No entanto, Zinberg (1984) nos alertava, há décadas atrás, sobre como permanecia na cultura norte-americana uma profunda aversão em reconhecer o fato de existir uma generalizada preocupação dos usuários, recreativos ou não, das mais diversas drogas, com o controle de seu uso. Como resultado, a cultura norte-americana dos anos 1970 e 1980 do século passado e, porque não, a brasileira do início do século XXI, insistem em diminuir a importância de muitos costumes sociais, sanções e rituais que possibilitam ao usuário de drogas ter certa capacidade de exercer algum controle sobre seu uso. Para ambas as situações, a existência de um módico controle da parte do mais compulsivo usuário e a preocupação geral com o uso de drogas por parte dos usuários mais controlados não podem ser ignoradas. Portanto, o espectro do uso de drogas deve ser ampliado e incorporar o uso ocasional e também o uso controlado, além da experimentação e do abuso de drogas, como na ilustração abaixo:

Figura 35 - O espectro do uso ao abuso de drogas

Experiência - Uso Ocasional - Uso Controlado - Uso Abusivo

Fonte: Coleção particular do autor.

O modo de pensar que ignora o setting social, não é capaz de compreender como o uso de intoxicantes tende a variar a cada fase da vida, status e mesmo localização geográfica. Muitos dos que fizeram uso pesado de intoxicantes quando adolescentes diminuem ao atingirem a maturidade e após mudarem seu setting social (amigos e circunstâncias). Assim como alguns adultos, à medida que se tornam mais bem-sucedidos 
podem aumentar seu uso. Por exemplo, um homem nascido e criado no campo pode mudar seus hábitos significativamente após mudar-se para a cidade grande. Enormes variações de uma época para outra podem também ser encontradas no uso social de intoxicantes, especialmente álcool, em vários países.

\section{Setting. padrão de uso e rituais para Zinberg e o consumo de crack}

Debrucemo-nos um pouco mais sobre a obra de Zinberg porque ela nos permitiu compreender de modo sistemático como o contexto social veio a adquirir imensa relevância teórica para a discussão do uso de substâncias. Nossos dados e conclusões não precisam estar em total consonância com aqueles tão brilhantemente expostos em Drug, Set and Setting. Mas, para os fins deste trabalho, o que nos importa é o modelo para pensar outros contextos. Não pretendemos simplesmente usar um quadro de referências para "outro estado de coisas" (LATOUR, 2012, p. 208), mas nos valer dos conceitos trabalhados por Zinberg para podermos dirigir nosso olhar tanto na pesquisa de campo, quanto na análise de dados. Sem dúvida, existem diferenças entre o uso de psicoativos nos EUA e na região central da cidade de São Paulo; também entre este uso nos anos 1960 e 1970 e o realizado atualmente. Porém, mais que uma moldura a conter nosso pensamento, o modelo pode servir para nos propor caminhos, direções e enfim, nos inspirar. ${ }^{91}$

No Vietnam, as evidências descritas acima, mostram que a droga era utilizada pesadamente para obscurecer os acontecimentos da guerra, com pouca atenção ao controle. Porém, muitos veteranos usaram heroína no Vietnam, sem tornarem-se adictos. Cerca de metade dos homens que usaram heroína no Vietnam e que eram adictos, usaram heroína após a volta aos EUA e

91 Ademais as razões expostas, não existem até então, em língua portuguesa, uma descrição mais aprofundada do modelo zinberguiano. 
apenas $12 \%$ tornaram-se readictos a ela. O setting terrivel da guerra, embora pudesse ser compensado pelo companheirismo entre militares, foi responsável por certo padrão destrutivo de uso. O setting das ruas do centro de São Paulo, por nós encontrado em nossa etnografia, possui seu aspecto de "communitas". Mas, certamente, a rua como a guerra, impõe condições dramáticas para a sobrevivência e não poderia ser diferente para os usuários do crack. Para Zinberg é necessário compreender em cada caso como as características específicas da droga e da personalidade do usuário interagem e são modificadas pelo setting social e seus controles. Vejamos o quadro abaixo:

Figura 36 - Setting e padrões de uso de drogas

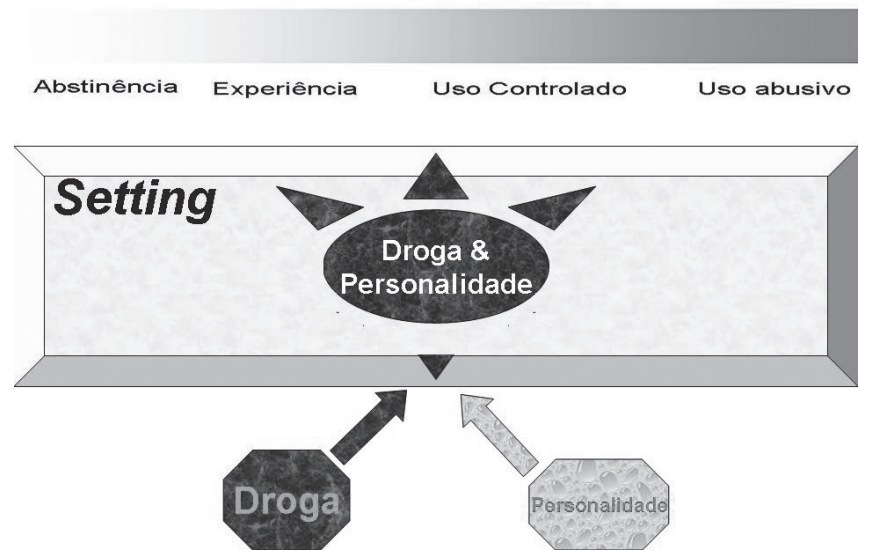

Fonte: Coleção particular do autor.

A cultura americana, como vimos acima, não reconhece plenamente, muito menos apoia o uso controlado das drogas ilícitas. Os usuários são declarados "desviantes", como uma ameaça à sociedade, ou como "doentes" e necessitados de ajuda, ou ainda "criminosos" e merecedores de punição. Este quadro não se diferencia substancialmente no cenário brasileiro. Socializa- 
ção centrada na família para o uso não está disponivel, portanto, os pais dizem aos filhos para não usarem drogas porque são prejudiciais e os jovens desconsideram este aviso porque sua própria experiência lhes diz o inverso. Seu grupo de usuários e a cultura da droga reforçam sua própria descoberta de que o uso de drogas em si e por si não é ruim ou mal e que os avisos vindos do mundo adulto são irreais. Os jovens poderiam simplesmente pensar: "Eles estão errados sobre maconha; porque eu deveria acreditar no que eles dizem sobre cocaína?". Se os pais tentam uma abordagem diferente e dizem aos jovens que algumas drogas são tranquilas, mas outras têm um componente de alto risco e deveriam ser evitadas, sua posição novamente é vulnerável. Além do mais, por aconselhar suas crianças que algumas drogas ilícitas são menos danosas que outras, os pais são colocados em uma posição dificil em ter de aprovar uma atividade ilegal e seu papel como transmissores da moralidade pública fica evidentemente inconsistente. Caso os pais queiram obter conhecimento de primeira mão experimentando drogas, terão de lidar com a inversão do papel tradicional entre instrutor e pupilo. Esta situação cria enorme ansiedade nos pais e dificilmente eles conseguem sentir os efeitos. Resumindo, para Zinberg (1984) o uso de drogas ilícitas é uma situação sem vencedores para todos, mesmo para aqueles que tentam planejar e ensinar cursos úteis de educação sobre drogas.

No caso da mídia de massa, muito da informação provida é dramaticamente oposta ao uso de drogas e à possibilidade de uso controlado. Sem a família, a escola e a mídia, a tarefa cai diretamente sobre o novo grupo de pares $^{92}$ - um substituto inadequado da geração cruzada, da socialização de longo termo. Associar-se com usuários controlados é uma questão de sorte. No início de suas carreiras como usuários, os indivíduos

92 São os agentes presentes no contexto de quem inicia o uso de alguma droga. No caso do uso controlado, os agentes presentes nos rituais de uso são geralmente, outros usuários controlados. 
podem se envolver com outros tipos de grupo, cujos membros não estejam escolados no uso controlado, ou em um grupo em que o uso compulsivo e comportamento de risco sejam as regras. Eventualmente, estes sujeitos podem se tornar usuários controlados, mas somente após eles terem se realinhado com novos companheiros - uma dificuldade e um processo incerto. Infelizmente, muitos usuários adolescentes nunca fazem esta transição. Vimos anteriormente, como Antônio iniciou seu uso de crack em um grupo majoritariamente constituído por pares inexperientes e com apenas um único usuário mais antigo, porém, apegado a um padrão possivelmente abusivo, isto certamente não contribuiu para uma socialização no uso do crack voltada ao uso mais controlado. O caso de Esmeralda é ainda mais dramático. Ela encarava na rua, toda uma população usuária abusiva, além de um ambiente físico que dificultava a rotina de sono diário.

Figura 37 - Grupo de pares e padrão de uso

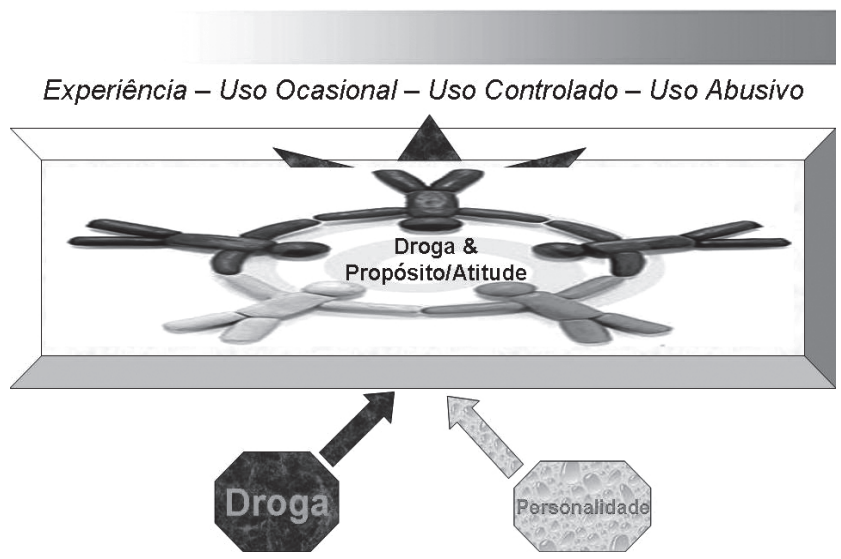

Fonte: Coleção particular do autor.

No caso dos usuários de heroína, as variações de força e pureza fazem da tarefa de controlar dose e o efeito fica mais dificil. 
Além disto, a política proibicionista contribui ativamente para a prevalente dicotomia entre abstinência e uso compulsivo. Isto se torna extremamente complexo para alguém que queira usar drogas e escolher um padrão de uso moderado. Mesmo assim, os rituais de controle e sanções funcionam para Zinberg (1984) em quatro modos básicos e sobrepostos, ${ }^{93}$ a saber:

- As sanções definem uso moderado e condenam uso compulsivo, no caso dos usuários de crack, ouvimos do nosso interlocutor por diversas vezes a seguinte máxima: "Você deve saber usar para não ser usado". Já os usuários controlados de opiáceos pesquisados por Zinberg têm sanções limitando frequência de uso a níveis abaixo que os requeridos para adicção e muitos têm sanções especiais como "não use todo dia”. Um ritual completando esta sanção restringe o uso aos finais de semana. Veremos mais à frente, como o Programa DBA possibilitou aos usuários de crack rapidamente desenvolver rituais relativos a trabalho, estudo, alimentação e sono capazes de servir como sanções ao uso imoderado de crack;

- As sanções limitam o uso a cenários, ambientes, contextos físicos e sociais, como por exemplo, a máxima para psicodélicos: "Use em um bom lugar, em boa hora, com boas pessoas". Dois rituais consonantes com esta sanção são selecionar um cenário rural aprazivel para o uso do psicodélico e a hora do uso para evitar dirigir "viajando". Entre nossos

93 Zinberg trabalha as sanções sociais aparentemente sob influência de Durkheim, para ele, os fatos sociais consistem em "maneiras de fazer ou de pensar, reconheciveis pela particularidade de serem suscetiveis de exercer influência coercitiva sobre as consciências particulares". (DURKHEIM, 1995 , p. 28) Esta coerção social é devida "ao prestígio de que estão investidas certas representações [...] os hábitos individuais ou hereditários apresentam esta mesma propriedade: dominam-nos, impõem-nos crenças ou práticas. Todavia a dominação é interior; pois os hábitos existem por inteiro em cada um de nós. Ao contrário, as crenças e práticas sociais agem sobre nós a partir do exterior: assim a ascendência exercida por um e outro é muito diferente". (DURKHEIM, 1995, p. 29) 
interlocutores usuários de crack, antes do Programa DBA, os rituais de uso se prendiam a seleção do barraco como ambiente propício e a se evitar fumar na presença de crianças e do "Zé Povinho";

- As sanções identificam efeitos potencialmente indesejados e os rituais incorporam as precauções a serem tomadas antes e durante o uso. Usuários de opiáceos podem minimizar o risco de overdose usando somente uma parte da droga e esperando para calibrar seus efeitos antes de usar mais. Usuários de crack de certa forma dosam quantidades de Corote, ou pinga com o crack, dependendo de seu objetivo no momento. Muitas vezes a cachaça pode ser utilizada para proporcionar coragem em um "corre" mais arriscado. O uso do álcool também está ligado a precaução contra os efeitos indesejados do uso do crack, como a paranoia. Além disto, eles procuram alimentar-se e levam água à "biqueira";

- As sanções e rituais operam para compartimentalizar o uso de drogas e apoiar as obrigações não relacionadas ao uso por parte do usuário e seus relacionamentos. Usuários podem orçar a quantia em dinheiro que gastam em drogas, como fazem para entretenimento, ou podem usar apenas à noite ou finais de semana para evitar interferir no desempenho no trabalho. Isto foi testemunhado por nós a partir da implantação do Programa DBA e veremos mais à frente. O quadro abaixo mostra a relação entre rituais e sanções relacionadas ao uso de drogas.

O processo pelo o qual rituais de controle e sanções são adquiridos varia de sujeito para sujeito e sem dúvida, para Zinberg (1984), o mais importante recurso de preceitos e práticas para controle é o grupo de pares. Apesar da imagem popular da pressão dos pares como uma força corruptora empurrando indivíduos frágeis para o abuso de drogas, suas entrevistas 
mostraram que muitos segmentos da cultura da droga haviam tomado uma firme posição contrária ao abuso de drogas.

Figura 38 - A relação entre rituais de uso e sanções

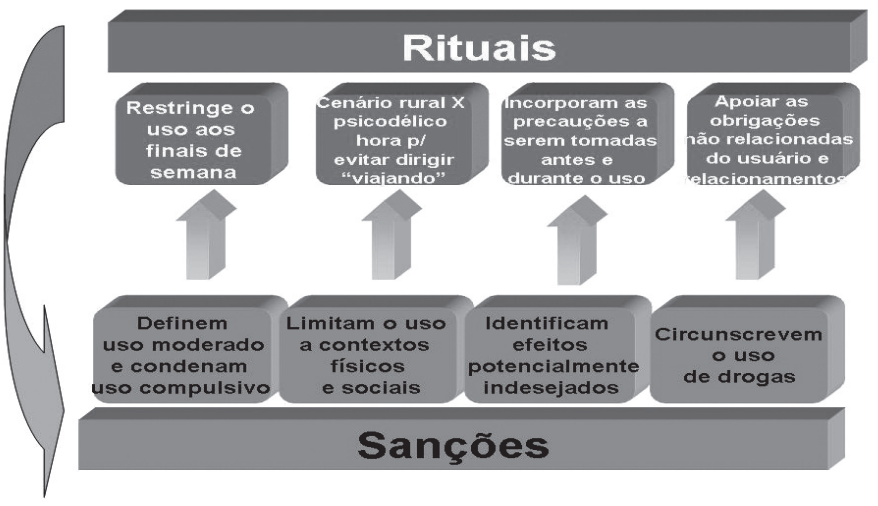

Fonte: Coleção particular do autor.

Ao deixar de tratar do uso controlado para iniciar suas considerações sobre o abuso, Zinberg irá fazer uma revisão histórica para determinar a genealogia do termo "abuso de drogas". Corroborando outros autores como Hart (2014) e Escohotado (1989), Zinberg observa que o uso desse termo aparentemente tivesse sido aplicado primeiramente ao uso de cocaina por negros do sul dos EUA. Originalmente, refletia preconceitos de raça e classe contra usuários negros, destacando a respeito dos efeitos perigosos da cocaína. Esse estigma foi estendido ao uso de ópio pelos chineses expressando o medo de uma minoria desprezada. O Harrison Narcotic Act, de 1914, colocou sob o termo "abuso de drogas", o uso de morfina e heroína. Uma serie de regulamentações posteriores da Suprema Corte transformou o uso não subscrito de opiáceos de um mau hábito em atividade criminal. Mesmo médicos perderam seu direito a prescrever opiáceos. Adictos do meio rural, incapazes de 
abandonar a droga, moveram-se às cidades costeiras onde os mercados ilegais cresceram e a animosidade pública em volta da adicção se desenvolveu.

O termo "adicção" mudou de significado no início do século $\mathrm{XX}$, de mau hábito da guerra civil, doença do soldado, o uso não prescrito de morfina se espalhou e passou a ser evidência de fraqueza de caráter ou mesmo de degenerescência. Até então, opiáceos eram "medicamentos próprios de deus" e apesar de desaprovada, a adicção era tolerada. Era específico de mulheres brancas rurais vistas com pena. Entre os anos 1910 e 1920, a palavra "adicção" começa a ser aplicada ao uso culturalmente desaprovado de certas drogas, tanto quanto o termo "abuso de drogas" é usado hoje. Em 1912, Charles B. Towns descreveu o que chamou de "tríade adictiva": fissura crescente, aumento da tolerância e sindrome de retirada. Hoje, segundo Zinberg (1984), adicção é genericamente aceita como um termo científico que descreve a dependência fisiológica inevitável que acompanha o continuo e pesado uso de substâncias (como opiáceos, barbitúricos, ou álcool) que possuam certas características farmacológicas.

Numa postura crítica a esta visão, primeiramente, é impossivel, para Zinberg, definir "crescimento da fissura" precisamente, ou limitar esta noção ao abuso de drogas. O viés por trás da definição é que fissura conota fraqueza e senso de desespero que pode levar ao comportamento antissocial e até mesmo ao criminal. Por outro lado, a tolerância crescente a certa droga foi aceita como progressão aritmética: após alguém usar uma substância certo número de vezes irá precisar de um aumento correspondente na quantidade para obter o mesmo efeito. Esta ideia ignoraria as importantes diferenças entre os indivíduos sobre como conseguem lidar com quantidades diferentes de drogas.

Para o médico e professor de Harvard, uma razão para a prevalência de definições de abuso de drogas que não são nem 
lógicas ou científicas é a força do moralismo puritano na cultura americana, que desaprova o prazer e a recreação proveniente de intoxicantes. A ideia de que o prazer, ou melhor, o tipo de prazer que leva ao escapismo e euforia, é potencialmente perigoso e precisa ser racionado estaria impresso na consciência americana. Porém, tal como observou Becker (2008), muitos usuários de maconha e psicodélicos consideram que seu uso de drogas é aceitável e prazeroso e desafiam a sua definição social como desviantes. Por outro lado, a pesquisa de Zinberg revelou como mesmo usuários moderados também refletiam atitudes e valores puritanos ao se culparem pelo seu uso. Então, usam por propósitos "sérios" como na intenção de obter inspiração (insight) pessoal ou religiosa - e expressam desdém e até rotulam como abusadores aqueles que procuram prazer. Os acusam de desejarem apenas ficar altos e aproveitar sua experiência psicodélica de um modo sensual. Lembremos que para Timothy Leary e seus seguidores nos anos 1960 do século passado, o LSD era chamado de sacramento.

A imposição da moralidade puritana sobre assuntos científicos para definir abuso de drogas é também aparente no desacordo encontrado na literatura científica sobre a natureza da adicção - especialmente da heroína. Zinberg observa como alguns estudiosos comparam o efeito da heroína ao orgasmo sexual e vimos a mesma comparação entre uso de crack e orgasmo no Brasil.

Fumar uma pedra de crack é comparado a uma quantidade de neurotransmissores iguais à de um orgasmo. Com a diferença de que se pode ter um orgasmo a cada cinco minutos. Nenhum ser humano, com uma vida normal, pode isso! Essa é a grande questão: os fatores associados à rapidez com que o usuário se torna dependente químico. (VIDAL, 2013, p. 1)

Diferentemente do propalado orgasmo, depois de prolongado uso de heroína, os sujeitos investigados por Zinberg experi- 
mentaram, segundo ele, uma desejável mudança de consciência caracterizada por aumento da distância emocional muito aquém da euforia, ou seja, o efeito procurado no uso da heroína era algo muito distante do orgasmo. Fato semelhante, não no efeito propriamente dito, mas em seu distanciamento do orgasmo pudemos verificar entre nossos interlocutores usuários de crack. A "brisa", procurada na forma de "sintonia", se mantém muito distante do apelo sexual, embora tenhamos percebido ser o "Morrinho", ao lado da "biqueira" a céu aberto, um local para encontros amorosos entre usuários de crack e também tenhamos presenciado seu uso entre casais nos barracos.

Portanto, para Zinberg, o abuso de drogas não pode ser definido em abstrato, precisa ser determinado em uma base de caso a caso. Ele terá dois padrões de mensuração: quantidade de uso e qualidade de uso. Quantidade de uso se refere ao tamanho e frequência da dosagem. Qualidade concerne a como a droga é usada ou as condições de uso que inclui o modelo de uso e o contexto social (quando, onde e com quem a droga é usada), ou seja, o conjunto de condições de uso da droga quanto ao local na qual é usada, o grupo de usuários com quem se compartilha o uso e o encadeamento das diferentes ocasiões de uso.

Em Zinberg (1984), apenas nos casos de doses em níveis extraordinários seria pertinente se considerar a quantidade de uso como evidência padrão para diferenciar uso de abuso. Segundo ele, fora destes níveis, medir quantidade pode não ser um modo prático de medir abuso e mais, o modelo da quantidade não é igualmente aplicável a todas as drogas. No caso da maconha é difícil estabelecer uma dose abusiva. Vimos acima, como para Becker (2008) sequer esta possibilidade á cogitada, dado partir este autor da premissa de ausência de uso problemático da substância. Porém, para Zinberg, os usuários pesados de maconha se assemelhariam àquelas pessoas habituadas a tomar um comprimido para dormir, mesmo após este não 
ser mais necessário em termos da falta de sono. Ele considera, portanto, quantidade (incluindo frequência) uma variável de difícil comparação e quando ele tenta diferenciar a quantidade mínima de um experimentador para um usuário ocasional, chega ao acordo na frequência de mais de uma vez por mês para uso ocasional. Porém, encontra ainda mais dificuldade em decidir por um critério para o uso máximo e, acaba por fazer da qualidade do uso seu maior critério. Assim, podemos concluir com Zinberg a respeito da qualidade do uso de drogas e das dificuldades em bem utilizar este conceito:

Julgamentos sobre qualidade do uso devem levar em conta uma complexa gama de fatores. Aqui o elemento social é geralmente mais importante que o farmacológico. Ter a prática regular de começar um longo dia de bebedeira cedo de manhã é bem diferente de ocasionalmente ingerir uma dose de LSD a mesma hora do dia. O uso do álcool - um depressivo significativo do sistema nervoso - como um 'abridor de olho' matutino é um claro indicador de problema. O que também será verdadeiro sobre o LSD se seu uso for da mesma natureza compulsiva; mas se a dose matinal de ácido tiver sido cuidadosamente planejada e for acompanhada por atividades específicas, usualmente levadas em um cenário social, a qualidade do uso será radicalmente diferente. (ZINBERG, 1984, p. 44, tradução nossa)

Durante a década de 1970, nos EUA, ocorreram mudanças drásticas na qualidade do uso que tornaram a experiência com LSD menos cataclísmica. Esta diferença se dará, na opinião de Zinberg, devido a mudanças principalmente no propósito de uso. No início dos anos 1970, a admissão de usuários de psicodélicos para tratamento em serviços de saúde mental por episódios psicóticos agudos e mesmo de longo termo, passiveis de ocorrer frequentemente no final dos anos 1960, desapareceu por completo. Ele observou um importante dado da National Commission on marihuana and Drug Abuse a respeito da quantidade de psicodélico usada; ela não declinara até 1974. Ainda mais, desde que os recursos psiquiátricos estabelecidos não fo- 
ram capazes de lidar com as más experiências com drogas com sucesso, a contracultura havia começado a invocar seu próprio "pessoal" experimentado para lidar com as más viagens. Muitos usuários, ademais, estavam dispostos simplesmente a ter uma má viagem, sabendo ser o problema um efeito transitório da droga e não um indicativo de insanidade. Mesmo aqueles entre os sujeitos investigados na pesquisa de Zinberg com histórico de uso pesado de psicodélicos, não costumavam mostrar interesse no pensamento religioso do oriente ou em um estado de consciência mais elevado, fato comum alguns anos antes. $\mathrm{O}$ novo contexto social, um elemento qualitativo, parece ter sido o fator predominante nesta mudança, esse ambiente era marcado por um uso mais hedonista e menos afeito às buscas espirituais. Porém, Zinberg não nega o fato de viagens frequentes de ácido em curto período de tempo poderem resultar em uma mudança de perspectiva e modificações intrínsecas de personalidade. Estas mudanças poderiam ser interpretadas pelos usuários como, por exemplo, um crescente interesse em abstração e espiritualidade. No entanto, o mais importante fator de proteção seria a diminuição da vulnerabilidade de usuários inexperientes, posterior ao desenvolvimento da sanção: "use a primeira vez sempre com uma pessoa experiente".

Para resumir, abuso de drogas em Zinberg (1984) pode unicamente ser determinado em bases individuais, pela observação de efeitos adversos do uso, por exemplo. Abandonar o termo "abuso de drogas", segundo este autor é um pré-requisito necessário para entender porque e quando pessoas usam drogas, como elas as usam, e, acima de tudo, se elas podem usá-las com sucesso - quer dizer, de modo controlado. Libertar-se da ambiguidade de uma das palavras código enunciadoras de um pensamento errôneo da sociedade sobre o uso de drogas dará aos investigadores a chance de encontrar e empregar termos claros, precisos e realísticos, além de tornar possivel enfrentar o desafio de desenvolver e estender um controle sobre o comportamento de tomar drogas. 
A adoção do termo "uso controlado" ao invés de "uso ocasional" na pesquisa de Zinberg reflete o interesse em entender quão controlado - ou seja, quão consistente e bem sucedido - tal uso ocasional poderia ser. Interessa-o ainda pensar como o dano potencial do uso de drogas poderia ser minimizado e encontrar sujeitos que fossem moderados e cuidadosos a respeito de seu uso de drogas. O mais óbvio requisito é que os candidatos não fossem usuários tão frequentes que seu uso pudesse interferir com sua vida familiar, amigos, trabalho ou escola e saúde. Múltiplos usos diários de maconha, heroína, ou LSD, assim como seu uso diário, foram eliminados imediatamente. Assim sendo, se recrutaram sujeitos que haviam usado uma vez por semana ou menos por todo último ano, ao menos até a entrevista inicial. Assim, ter sucesso no uso seria conseguir desfrutar os efeitos recreativos desejados e evitar as consequências negativas como overdoses, badtrips e sindromes de abstinências.

Se for para levarmos a sério a ideia de contexto social trazida por Zinberg e a partir daí buscarmos uma melhor compreensão do uso de crack nas ruas do centro de São Paulo, devemos nos perguntar qual o significado de uso controlado de crack para pessoas em situação de rua, particularmente para aquelas que vivem em "biqueiras", ou na Cracolândia. Não podemos, é claro, assumir os critérios de Zinberg, com relação à frequência semanal de uso, mas podemos ter como parâmetro a qualidade das relações com o entorno, o setting do usuário. Um critério possivel para diferenciar o "nóia" do "usuário" é capacidade de não ser um "parasita", de conseguir "fazer seu corre" e ser respeitado na "biqueira”. Seja como usuário, "vapor", "contenção", "sintonia", ${ }^{94}$ disciplina, ou qualquer outro papel que se atribua a quem usa crack e vive no entorno de um espaço psicotrópico. No caso baiano, vimos no trabalho de Malheiros (2012), como o perfil do "sacizeiro" se diferencia do usuário; em nossa

94 "Sintonia" é um papel atribuído pelo PCC aos seus prepostos nos locais de comércio e uso de crack. 
pesquisa participante pudemos perceber claramente o repúdio ao "parasita" e a importância de se observar a máxima: "usar sem ser usado". Como nos declarou certa vez Dobem: "existem aqueles que se entregam", ou seja, para além de "ser do crack", certos usuários seriam usados pela droga ao invés de usá-la. Assim, vemos a importância de considerar o padrão de uso de nossos interlocutores no interior das expectativas relativas a seu grupo de pares, ou seja, seus amigos ou "parças".

Padrões de amizade e atividades do grupo de pares jogam o papel mais importante na influência dos estilos de uso controlado e compulsivo. A mais importante diferença, na pesquisa realizada por Zinberg (1984), foi que usuários controlados tendem a possuir mais amigos e associados. Nenhum sujeito controlado era um "solitário", comparados aos 11\% dos compulsivos e mais, 68\% dos sujeitos controlados, comparados a 37\% dos compulsivos, tinham "vários grupos de amigos". Compulsivos não apenas sofriam uma redução drástica nos amigos, mas os que eram solitários afirmaram serem assim porque os amigos os haviam abandonado. ${ }^{95}$

O modo como um indivíduo usa drogas é influenciado pelo modo como seus associados as usam, ou seja, sujeitos controlados tendem a conhecer mais usuários controlados que compulsivos. Evidentemente, sujeitos controlados mantém uma rede mais ampla de conexões sociais - um grupo de pares mais

95 Existe um impressionante padrão de diferenças entre os dois grupos, não controlado e controlado, pesquisados por Zinberg quanto à motivação para o uso, assim, mais compulsivos que usuários controlados declararam os primeiros quatro motivos para usar: "viajar", "sair da realidade", "correr perigo" e "aliviar a depressão". Ao segundo grupo de motivações "gostar da onda", "uso social", "recreação" e "relaxar" - que podem ser conceitualizados como uso social ou celebratório. Em todos os casos mais usuários controlados que compulsivos tiveram estes motivos "saudáveis". Estes dados aparecem para emprestar apoio à visão que o uso compulsivo representa um tipo de automedicação, uma tentativa de acalmar um estado de dor interna. Há uma boa razão para supor, entretanto, que no caso de nossos usuários compulsivos de crack, isto foi afinal muito mais consequência do contexto - o isolamento e o stress ambiental resultante da situação de rua. 
largo - que os proveem com retornos valorizados e reforço para o uso moderado, enquanto sujeitos compulsivos, que tendem a conhecer mais usuários compulsivos e menos usuários controlados e que também tendem a ser solitários, parecem ficar fora do campo de influência dos usuários mais moderados.

A situação de rua revelou-se em nossa pesquisa como o ambiente privilegiado para alguém relacionar-se com outras pessoas que fazem uso cotidiano de crack e Corote, ${ }^{96}$ especialmente. Para poder estar no "corre", principalmente o de tipo mais arriscado e no intuito de sobreviver às noites perigosas da região central, muitas vezes sem dispor de um barraco e mesmo dispondo, sujeito a interrupções constantes, como é o caso de uma "biqueira" a céu aberto. Vimos como, no sentido de "manter-se alerta" para suportar sua "caminhada", a companhia de outros "parças" na mesma situação, dispostos a manter seu uso, sem cair no papel de "parasita" é fundamental. Portanto, a companhia de "parças" e "usuários fortes" de crack é uma maneira de sobreviver na rua e este fato corrobora a ideia central a Zinberg relativa à importância do grupo de pares e seu padrão de uso. O padrão binge prevalece na rua, muito pela influência do entorno. Se usa droga até o total esgotamento porque o ambiente não permite o descanso reparador; pela necessidade de se estar na segurança da companhia de conhecidos que, por sua vez, também são usuários pesados.

A proximidade desenvolvida ao se compartilhar uma experiência ilícita e prazerosa dá ao usuário um senso de pertencimento a algo especial e impróprio que não á conhecido pelo "mundo careta". Maconha certamente provê um tópico especial de conversação. Isto faz o usuário se sentir como um membro de um clube. Com relação aos não usuários, muitos dos sujeitos pesquisados por Zinberg reportaram estranhamento frente a velhos amigos que não usam, por temer críticas e desaprovação. Sobre os efeitos do LSD, a pesquisa de Zinberg detectou

96 Popular marca de aguardente. 
certa influência nos relacionamentos, um tipo de ligação poderosa entre as pessoas que "viajavam" juntas. Um sentimento de proximidade pessoal. A experiência compartilhada parece estabelecer um sentimento de afinidade.

As características empatogênicas das drogas são aquelas relacionadas à sua associação com a produção de sentimentos de empatia, amor e proximidade emocional entre seus usuários. Estas características foram estudadas pela primeira vez de um modo específico pelo psicólogo alemão, radicado nos EUA, Ralph Metzner, companheiro de Timothy Leary em seus estudos com LSD em Harvard, no início dos anos 1960. Um dos entrevistados por Zinberg descreve assim os efeitos empatogênicos do LSD:

Eu nunca havia falado tão abertamente sobre mim antes na minha vida. E foi fácil. Eu não me senti, você sabe, como escondendo nada sobre mim, ou que o que eu era tão terrivel. Então, ele me contou sobre ele e eu pude entendê-lo e me sentir próximo e pensar que tudo que me disse sobre ele era ok, assim como era comigo. (ZINBERG, 1984, p. 103)

Ainda mais destacado que o LSD neste sentido, a metilenodioximetanfetamina (MDMA), ou Ecstasy é reconhecidamente como uma droga empatógena. Examinemos como a empatogenia vem a ser um dos efeitos procurados no uso do crack e ainda, como a "sintonia", termo êmico para designar a empatogenia do crack pode ocorrer sob determinadas condições. Em nossa pesquisa de campo tivemos a oportunidade de presenciar, como já descrevemos anteriormente, o uso de crack em condições caracterizadas pelos usuários como profundamente empáticas, ou com "sintonia" entre eles. Ao mesmo tempo, tivemos relatos de convivência dificil com familiares e uma progressiva aproximação dos outros usuários de crack. Foi o caso de Mariano, um morador da Cracolândia, que teve desavenças com sua avó devido à intolerância desta em relação ao seu hábito. 
Não observamos, entre nossos interlocutores, descrição de situações prazeirosas de contato com não usuários de crack quando sob efeito da droga, ou de desejo em participar de ocasiões sociais desvinculadas do uso, como as descritas por Zinberg entre os usuários de LSD, chegando estes a irem à igreja para conversar durante os efeitos do alucinógeno. Pelo contrário, possivelmente por tratar-se de usuários em situação de rua, as descrições foram de um forte sentimento de inadequação quando em situações não relacionadas ao uso de crack, ou à vida na rua. Abaixo, um trecho de uma conversa com um interlocutor, em seu barraco sobre as dificuldades em relacionar-se fora da "biqueira":

Zezé - Fome. A fome de usuário acumula porque a gente queima gordura, mas tem uma hora que a necessidade de comida é tão grande que um arroz azedo é banquete. Quando você vê usuário mexendo no lixo. Ele perde totalmente a vergonha, o pudor, o preconceito, ele se desveste de qualquer formação psicológica e social quando tem fome.

Ygor - Se você andar na rua agora, você acha que as pessoas te vêm como usuário, ou não?

Zezé - Sim, porque as pessoas percebem o mau tratamento com o corpo. Hoje você está me vendo limpo, porque tomei um banho. Mesmo tendo tomado banho você vê mais uma pessoa que se preocupa em ter o crack fumado do que cuida da sua aparência e higiene, cabelo, barba.

A ida à rua aparece como um clamor do corpo por alimento e ao mesmo tempo, este corpo carrega os estigmas desqualificantes capazes de inabilitar o indivíduo "para a aceitação social plena". (GOFFMAN, 1975, p. 7) A fome leva do barraco à rua e esta empreitada no universo das interações sociais com não usuários conduz à possibilidade de exposição aos olhares e julgamentos do "Zé Povinho". Esta exibição involuntária abre a possibilidade de os sinais corporais mencionados por Zezé, como o cabelo descuidado, a barba mal feita, a sujeira, enfim, o 
maltrato com a aparência e higiene revelarem seu status moral. Este faria do usuário de crack, possivelmente, "um escravo, um criminoso ou traidor". (GOFFMAN, 1975, p. 11) Teríamos assim, configurados os escravos da droga passiveis de cometer qualquer crime sob abstinência e ainda representados, contra sua vontade, como traidores da ética do trabalho, tal qual os usuários de drogas norte-americanos pesquisados por Zinberg. Porém, em nosso caso, o contexto é ainda particularmente marcado pela ideologia da "São Paulo que não pode parar".

A sujeira, o descuido com o corpo e a perda da "vergonha" e do "pudor" por parte do usuário de crack disposto a remexer o lixo, como nos assinalou Zezé, acabam por formar uma gama de atributos capazes de colocar certos indivíduos em uma determinada categoria, ainda mais ao encontrarem-se no ambiente da rua. A categorização cria uma série de expectativas não apenas quanto ao comportamento do outro, mas também expectativas quanto à identidade social de alguém. Assim, é possível ao não usuário apropriar-se de certa maneira estereotipada de relacionar-se com estas pessoas, uma "rotina de relação social" (GOFFMAN, 1975, p. 12) para interagir com o "zumbi usuário". Ser "nóia”, craqueiro ou zumbi é carregar uma série de atributos depreciativos capazes de estigmatizar alguém, assim como de confirmar a normalidade de outro.

O usuário de crack se considera, portanto, um desacreditado com características distintivas desqualificantes imediatamente evidentes ao olhar do outro. Assim, outros atributos que estes indivíduos possam por ventura carregar consigo ficam impossibilitados de se mostrar a atenção daqueles com quem venham interagir. Tal a força do estigma em provocar no "Zé Povinho" a tendência a inferir "uma série de imperfeições a partir da imperfeição original”. (GOFFMAN, 1975, p. 15) O usuário de crack possui consciência disto, tanto que despreza o "Zé Povinho", mas também se envergonha na interação com ele. O termo "Zé Povinho" resume o ponto de vista do usuário de 
crack sobre os ocupados transeuntes da capital paulistana, ao movimentarem-se pela cidade, envoltos em seus afazeres. Em meio a vida agitada da metrópole, os paulistanos são capazes de encontrar tempo disponível para apontar em direção a eles, criticar, falar mal, enfim, demonstrar seu julgamento desqualificante através de um comportamento hostil com relação aos corpos dispostos nas calçadas, sob os barracos. Comportamento dedicado àqueles que portam seu cachimbo e possuem sinais físicos próprios do uso do crack na rua, como magreza, olhos embotados, andar trôpego, mãos enegrecidas e má vestimenta.

Procuramos demonstrar aqui como as atividades necessárias para a obtenção da substância são vividas de forma por muitas vezes prazerosa. É como se o uso da substância proporcionasse um tempo vivido no qual, atividades sociais, ocupacionais ou recreativas são trocadas por outras atividades mais interessantes como o "corre" e a "treta". Pessoas fumando, bebendo e se alimentando em roda são uma das atividades mais tipicamente sociais conhecidas. A análise do trabalho de Zinberg (1984) promovida acima, nos coloca a par da importância do contexto social para a compreensão do uso de drogas. Este ponto de vista nos permitiu dar um passo adiante do próprio Zinberg e percebermos a profunda atração do contexto social de uso do crack como um grande elemento agregador de parcela importante da população em situação de rua da cidade de São Paulo. Neste sentido, o prazer de estar entre pares interagindo pela conversa de temas próprios ao cotidiano como usuário de crack deve também ser levado em consideração, como ocorre nas "communitas" estudados por Victor Turner.

\section{A "communitas" em torno do uso do crack}

A “communitas"97 espontânea, como tratada por Victor Turner a partir da análise de obras literárias e exemplos históricos, será

97 Manteremos a palavra "communitas" entre aspas conforme faz Victor Turner. 
por nós aqui utilizada como recurso analítico para compreender o ambiente proporcionado pelo uso do crack e sua atração sobre os craqueiros. Serão focados três locais distintos: uma "biqueira" com fumódromo a céu aberto, a Cracolândia paulistana e uma "biqueira" com fumódromo em local fechado. O local de uso de crack pode ser visto em Malheiros $(2012,2013)$ como espaço de socialização no consumo da droga desde sua aquisição. Em Saporti; Sena; Silva (2010) o local de uso aparece como articulado à rede de empreendedores e de "bocas". Ele pode também figurar como espaço repleto de personagens abjetos. (RUI, 2012, p. 11) Uma visão mais generalizadora, para além do consumo de crack, concebe os locais de uso de drogas como contextos sociais capazes de prover um ambiente mais ou menos propício ao uso controlado. (ZINBERG, 1984) Finalmente, como em Grund (1983) e Alves (2014), o local de uso seria também um espaço onde a estrutura de vida do usuário teria influência sobre seu padrão de uso.

Nossas análises e conclusões são provenientes de uma observação participante entre usuários de crack da região central da cidade de São Paulo, mais especificamente nas regiões do Cambuci e nas proximidades da Estação da Luz, área também conhecida como Cracolândia. São locais de comércio e uso de substâncias psicoativas tornadas ilícitas, "territórios psicotrópicos” (FERNANDES; PINTO, 2004, p. 149), ou seja, interstícios espaciais apartados do cotidiano urbano regido pelos mercados de produtos e serviços legais. Um valor importante, como visto anteriormente, é o de preservar os não usuários do impacto provocado pela visão do consumo de crack; para tanto, recorre-se às tecnologias disponiveis na rua a fim de se obter abrigo e intimidade. Um dos locais de comércio e uso de crack por nós pesquisado é uma "biqueira", como se chamam os locais de venda de substâncias psicoativas tornadas ilícitas na cidade de São Paulo, com fumódromo a céu aberto. Isto significa haver lá comércio e uso constante do crack. Localiza-se em um 
beco, travessa da rua São Paulo e às margens da Avenida Radial Leste, no bairro do Cambuci. O uso de crack no local pode aglutinar mais de uma centena de pessoas e havia lá, cerca de dez barracos.

Sabemos que o barraco é a principal tecnologia disponivel na rua para o abrigo e proteção. Sua constituição é tão variada quanto são os materiais disponíveis, habilidades, propósitos e gostos pessoais. Surge, então, um ambiente íntimo, adequado para o uso seguro da droga, livre da vergonha de se estar agredindo os valores dos passantes, assim como da "radiação" vinda de fora. O ambiente externo ao barraco está na verdade amplamente interligado a ele, porque a "biqueira" com fumódromo a céu aberto é um lugar extremamente agitado, onde a troca recíproca de todo tipo de bem e serviço é constante. O barraco é suficientemente permeável a ponto de possibilitar a requisição de bens e serviços disponiveis no lado externo e ao mesmo tempo acompanhar alguma agitação maior na rua.

O barraco de alguém pode ser limpo e consertado por terceiros, tais serviços entrando no circuito da "treta". Não apenas os serviços, mas o próprio barraco pode ser vendido, trocado ou alugado. Ter um barraco em boas condições e muito frequentado é quase sempre garantia de acesso perene à pedra de crack. Sua construção e manutenção estão em consonância com a rua ou baixo de viaduto onde é erguido, sendo que antes do DBA, programa municipal dedicado à oferta de serviços aos usuários de crack, eles eram uma presença constante na Cracolândia.

A Cracolândia é um espaço de uso e comércio intenso. Compreendia, no início de nossa etnografia em fevereiro de 2013, parte da rua do Triunfo e rua dos Gusmões, assim como o quadrilátero entre a Alameda Glete, a Avenida Rio Branco, a Avenida Duque de Caxias e a Alameda Cleveland. Neste espaço, entre a Praça Princesa Isabel e a Estação Júlio Prestes estão o Largo Coração de Jesus e a Praça Júlio Prestes. 
Diferente dos dois locais de uso de crack brevemente descritos acima, a "biqueira" a céu aberto e a Cracolândia. Também pôde ser pesquisado por nós, o uso coletivo do crack em uma "biqueira" com fumódromo em local fechado. Trata-se de um cômodo construído em terreno murado, juntamente com outros poucos imóveis do mesmo tipo, localizado no bairro paulistano do Cambuci, em frente a um edificio ocupado por sem tetos. Um espaço fora da legalidade e isento dos deveres quanto aos padrões de construção, assim como dos direitos aos serviços de saneamento básico, constituindo-se, portanto, em um lugar intersticial. Nele, mãe e filha habitam e fazem uso de crack. A filha comercializa a pedra e a mãe trabalha como catadora de material reciclável. Muitos amigos circulam pelo local e ali fazem uso do crack, mas uma senhora se destaca pela maneira afetuosa como é tratada por todos: ela é carinhosamente chamada de Vó.

A conversa costuma fluir por toda noite, enquanto se fuma e vende pedras. Os cachimbos são constantemente modificados e reparados como é comum em qualquer roda de crack. Chama a atenção o cuidado com o trato do cachimbo de Vó por parte da traficante, aqui chamada de Amélia, a mesma interlocutora supracitada no início deste livro. Observo-a em seus movimentos precisos, ligeiros, enquanto desmonta e monta o "chimbó", um codinome para cachimbo de fumar crack. Ela retira a borra, prepara novas doses de pedra para si e para outros, principalmente Vó. Ao reparar o “chimbó” de Vó, Amélia age certamente movida por compaixão, porém, seu ato nos leva a pensar sobre sua habilidade artesanal. Proporcionar o máximo de absorção de fumaça a uma pessoa querida através da manutenção do cachimbo é a dimensão instrumental de sua ação. Porém, o pedido de Vó para que seu "boris" lhe fosse devolvido logo e a insistência da artífice em contrariar e ralhar com a pessoa que quer agradar, revela um desejo que poderíamos considerar próximo do "trabalho bem-feito por si mesmo” (SENNETT, R., 2012, p. 19), do artífice. À compulsão 
pela pedra, poderia acrescentar-se a obsessão pela perfeição? Produtora e usuária do cachimbo, envolta em um ritual voltado à maximização do fruir da pedra com a redução dos demais desejos, Amélia come pouco, não arruma seu barraco além do mínimo necessário à recepção de outros igualmente interessados na absorção da fumaça e bebe quase nada. Coisa nenhuma poderia estar mais longe de alguém entregue à satisfação desmedida dos desejos; nossa "usuária forte"98 se assemelha a uma asceta como S. Francisco de Assis.

Estas observações a respeito do trabalho voluntário feito fraternalmente por Amélia, traficante em uma "biqueira" em local fechado, assim como das trocas correntes no interior e exterior dos barracos em uma "biqueira" a céu aberto e na Cracolândia. Levam-nos a propor uma maneira de pensar o ambiente possibilitado pelo uso do crack, a partir da qual seja possivel lançar alguma compreensão a respeito de seu apelo e atração sobre os craqueiros para além da fissura proporcionada pela droga. Este apelo foi descrito pela autora de maior sucesso na literatura sobre o uso de drogas, Christiane Vera Felscherinow, ou simplesmente Christiane F. Ela relatou, no momento de elaboração deste trabalho, ainda com 53 anos de idade, ressaltando a relação do contexto social para o usuário de drogas através do seu segundo livro publicado em 2014, de onde tiramos esta breve citação:

Muitas vezes a causa de tudo isso não era apenas a heroína, mas o contexto social. Em determinado momento, mesmo sem a gente se dar conta, a vida passa a funcionar de tal maneira que nos leva sempre aos mesmos lugares e a repetir os mesmos comportamentos. E não me refiro apenas ao vício, mas também às outras coisas que sistematicamente nos fazem voltar à droga. Comigo, por exemplo, o problema de tudo isso no fundo é que não suporto ficar sozinha. Voltei então aos meus antigos conhecidos do reduto, mesmo que não fossem realmente amigos. Eles

98 Termo utilizado para designar usuários de grandes quantidades de crack. 
Jamais fomos zumbis

tinham o mesmo tipo de ocupação, de problemas e de histórias a contar que eu. Tudo isso propiciava uma rápida aproximação e a gente tentava chamar isso de amizade. (FELSCHERINOW; VUKOVIC,2014, p. 153, grifo nosso)

Esta senhora, cujo uso de drogas na juventude a levou a ser uma grande referência para sua geração - na qual o autor deste livro se inclui - percebeu claramente (e não poderia ser diferente visto sua experiência de 40 anos com o uso de drogas) a importância da atração exercida pelo contexto social na manutenção de certo padrão de uso. Nossa pretensão aqui é procurar na ideia de "communitas" uma chave capaz de nos proporcionar meios analíticos para desvendar o fascínio do ambiente que envolve o usuário de drogas, particularmente o crack.

As relações sociais dentro de determinado contexto social não devem ser consideradas apenas em sua forma socioestrutural. Outras modalidades, como a "communitas", servem de base para a constituição de relações sociais entre indivíduos não segmentados em posições sociais. Nesta forma de se relacionarem, os indivíduos podem interagir com autêntica reciprocidade. Marcada pela espontaneidade e imediatidade, a "communitas" opõe-se ao caráter jurídico/político da estrutura. Malgrado a satisfação que os participantes possam derivar de tal situação, a "communitas" estaria, por razões materiais de sobrevivência do grupo, condenada a ter uma vida curta e, em decorrência disto, as relações entre indivíduos retornariam a relações normatizadas entre "pessoas sociais". (TURNER, 1974, p. 161)

A roda de crack aproxima-se de uma das formas de apresentação da "communitas" conforme classificação de Victor Turner, que oferece como exemplo, a "communitas" existencial, correspondente aos happenings dos hippies dos anos 1960 e início dos anos 1970, nos EUA. Ela seria uma experiência de reciprocidade imprevisivel e única. Os hippies buscariam este estado de liminaridade, de estar no limite entre dois estados diferentes de 
existência, através do uso de drogas empregadas para "expansão do pensamento". (TURNER, 1974, p. 168) Não apenas as sociedades pré-letradas, mas também as sociedades complexas e estruturadas seriam entrecortadas por momentos de liminaridade espontânea, nos "intervalos entre os encargos das posições e condições sociais”. (TURNER,1974, p. 168) Os momentos de lazer e recreação, como os shows de rock, com suas luzes, som em alto volume e consumo de drogas, seriam para Turner oportunidades para se criar uma comunhão de uns com os outros. Esse seria um estado de completa reciprocidade e profundamente transformador, no qual se poderia ir até o íntimo de cada um e aí encontrar algo de intrinsicamente comunal e compartilhado. Uma existência em êxtase, ou seja, fora das normas e suas posições estruturais. Assim, a "communitas" aparece como uma grande tentação humana, a tentação do gozo dos sentimentos prazerosos proporcionados pela liberação das inclinações pessoais das amarras dos desejos e necessidades do social estruturado. Haveria, portanto, na "communitas" algo de mágico, capaz de proporcionar uma sensação de poder ilimitado, balizado apenas pela imposição mínima de limites para salvaguardar a existência; encontrar a relação ótima entre "communitas" libertadora e estrutura supridora constituiria o grande desafio dos envolvidos neste tipo de empreitada.

Um modo particularmente interessante de "communitas" existencial teria sido a vivida por S. Francisco de Assis e analisada por Turner. Nela, uma determinada concepção de pobreza foi colocada em prática e gerou certas atitudes com relação à propriedade. O ideal de $\mathrm{S}$. Francisco para a convivência com seus frades era o da completa desvinculação com o "sistema comercial do mundo" (TURNER, 1974, p. 175) e com os negócios seculares, voltando-se para a convivência entre os pobres, fracos, doentes e pedintes, até os limites da necessidade. Estes limites eram alcançados pelo deliberado apartamento do mundo comercial, com a vida suprida por recompensas as mais incertas 
possíveis como as da mendicância. Este seria, segundo Turner, o modo de vida buscado por certos hippies norte-americanos da virada das décadas de 1960-1970, particularmente aqueles em torno da famosa esquina de Haight-Ashbury - na cidade coincidentemente chamada de S. Francisco - sendo que o consumo de drogas também estaria profundamente ligado a esta perspectiva.

A procura por viver da mendicância, fora da vida comercial, seria um esforço para manter-se na liminaridade, nos interstícios da vida social daquele tempo vivido por S. Francisco e por seus frades. Neste espaço, a "communitas" poderia surgir. Ao entregarem-se nas mãos da providência procuram seguir o exemplo do Cristo nu e crucificado, ele próprio tendo vivido de esmolas, juntamente com sua mãe e discípulos. A fuga da propriedade era também a fuga da estrutura, pois os dois, propriedade e estrutura estão intimamente interlaçados nas formas sociais duradouras com sua estruturação e rotinização.

Nas duas "biqueiras" que frequentamos, assim como na Cracolândia, as "pessoas sociais" (TURNER, 1974, p. 161) eram representadas por aqueles com maior proximidade com o tráfico de drogas, na posição de "vapor" ou traficante. Porém, no caso de nossos interlocutores, sua posição como traficante, quando havia, estava mais próxima aos interstícios da estrutura do tráfico. Era uma posição extremamente frágil, mais próxima de um usuário/ "vapor" e não de um membro fixo em uma estrutura estabelecida. Seus valores se confundem com os valores dos demais usuários, a reciprocidade na "treta" se aplica também a eles. Compartilham as mesmas condições de vida, embora o "vapor" esteja mais sujeito às regras do crime organizado quanto à permanência na "biqueira" e também um pouco mais atrelado a deveres estritos de prestação de contas quanto à quantidade de pedras vendidas.

Comentamos até aqui, apenas duas "pessoas sociais" encontradas em "biqueiras", a de "contenção" e "vapor". Para o contexto da Cracolândia, poderíamos acrescentar as posições de 
sintonia, "disciplina", "primo" e "irmão" do PCC. Porém, é necessário salientar a plasticidade destes termos, que podem dizer respeito a realidades diversas, a depender do contexto vivido, como no caso "do sintonia e contenção". Na roda de crack, "sintonia" é a agradável sensação de fraternidade entre todos os participantes, sensação primordial à ideia de "communitas". Já na Cracolândia, o termo pode referir à "pessoa social" responsável pela segurança. Na "biqueira" a céu aberto da rua São Paulo, "contenção" é o responsável por receber quem chega; na "biqueira” em local fechado também havia alguém nesta posição. Já na roda de crack, "contenção" pode ser o termo designativo daquele responsável por buscar água, cigarros e Bic, caso estes acabem e até mesmo de colocar as pedras de crack nos cachimbos para garantir quantidades equânimes aos participantes da roda. Aí, existindo uma verdadeira cooperação "como uma troca em que as partes se beneficiam". (SENNETT, 2012, p. 15)

A “communitas" é fugaz e liminar; tenderá sempre a retornar à estrutura. Assim, com o tempo, a "communitas" espontânea cede às pressões por normatização devido à

"necessidade de mobilizar e organizar recursos e da exi-
gência de controle social entre os membros do grupo na
consecução dessas finalidades, a 'communitas' existencial
passa a organizar-se em um sistema social duradouro".
(TURNER, 1974, p. 161)

$\mathrm{Na}$ "communitas" normativa e duradoura está presente o imperativo de mobilizar recursos para o provimento das necessidades da vida, bem como o de mobilizar pessoas através de algum tipo de organização social com relações estruturais, comando e obediência. Já na "biqueira" da rua São Paulo, na de Amélia e na Cracolândia, o recurso advindo do "corre" individual pertence a quem o produziu e esta relação com a propriedade - como vimos no caso dos frades franciscanos - é fundamental para não deixar florescer "as sementes da segmentação e da hierarquia estruturais”. (TURNER, 1974, p. 166) Estamos, 
portanto, muito próximos a uma situação de igualdade, em um happening socialmente transitório proporcionado pelo uso de crack e pela fruição da "sintonia" como sentimento de fraternidade por todos os participantes da roda.

Na Cracolândia, antes do Programa DBA, a estrutura mais próxima aos usuários de crack era representada pelas "pessoas sociais" dos "disciplinas", "primos" e "irmãos" do PCC. ${ }^{99}$ As relações diretas e imediatas entre indivíduos poderiam ser vividas no interior do "fluxo" e nas rodas de crack. A atração do "fluxo" é devida ao seu aspecto "communitas", ou seja, indivíduos em relação direta uns com os outros, conversando em pequenos grupos e movimentando-se entre eles. O passar das horas se dá entre velhos e novos conhecidos, todos animados pelo exercício da treta - troca recíproca de bens variados afeitos ou não à parafernália de uso do crack - e pela "sintonia" proporcionada pelo uso.

Como pudemos presenciar, ao serem convidados a entrar em um estabelecimento comercial (como um bar ou lanchonete), usuários de crack costumam recusar o convite. Esta recusa, muitas vezes longe de ser envergonhada, mais comumente ocorre de modo orgulhoso, quase indignado. ${ }^{100}$ Entrar em qualquer bar, que não seja um daqueles pouquíssimos locais disponiveis no interior da Cracolândia, mais especificamente na rua Dino Bueno, é visto como comportamento de "Zé Povinho" e não de quem "é do crack". Tal qual frades a acompanhar S. Francisco, nossos interlocutores craqueiros romperam os laços com o sistema comercial, em um estado liminar e estabilizado de pobreza "levada até os limites da necessidade".

99 A polícia e os agentes do SUS pertenciam às suas estruturas próprias e estavam presentes na cena, mas não se encontravam abertas à participação dos usuários de crack em seu interior.

100 Presenciamos uma usuária ser expulsa do bar onde nos encontrávamos, por intencionar banhar-se no toalete do estabelecimento. É claro que estas situações também criam uma aversão da população em situação de rua a tais ambientes. 
(TURNER, 1974, p. 176) Assim, se os franciscanos da época de S. Francisco pediam esmolas, nossos craqueiros podem passar seus dias "mangueando". ${ }^{101}$ Livres da propriedade, libertam-se da estrutura, que fica relegada aos "vapores" e "contenções" contadores de dinheiro e prestadores de contas ao tráfico. A acumulação de bens é desencorajada pela própria cultura de uso. Os usuários de crack, que em algum momento de sua "caminhada" chegam a ter acesso a somas maiores de dinheiro, costumam utilizá-la no consumo da pedra até o esgotamento dos recursos financeiros.

O uso do crack é coletivo nos locais observados durante nossa pesquisa. Este uso possibilita a vivência de uma sociabilidade semelhante à "communitas" espontânea procurada, tanto pelos hippies quanto por S. Francisco de Assis. Nela, a pobreza é algo fundamental, que permite a manutenção de um estado desestruturado das relações sociais e possibilita relações fraternais entre despossuídos, marcadas pela reciprocidade das trocas na "treta" e menos afeita a relações baseadas em "pessoas sociais" com funções estruturadas. Essas são mais ligadas aos membros muitas vezes circunstanciais do tráfico de drogas, como o usuário/“vapor". Longe de ser "uma substância que dá à pobreza acesso ao sonhado consumo contemporâneo" (MEDEIROS, 2010, p. 182), o crack abre as portas para a negação deste consumo e para a vida em "communitas".

\section{Período e frequência de uso: o zumbi desmascarado}

Seja pelo seu aspecto às vezes maltrapilho, seja pelo seu comportamento destemido ou pelo olhar vidrado e sem vida, a mídia encarregou-se de caracterizar os usuários de crack como zumbis ou mortos vivos. (BOES, 2011) É como se houvessem cometido suicídio ao valerem-se da "droga que mata", mas permanecessem ainda meio vivos, moribundos, à espera da morte certa. Po-

101 Nome dado ao ato de pedir esmolas na rua. 
rém, se o termo faz algum sentido, é porque parece haver algo no comportamento dos usuários passivel de ser associado aos autômatos mal finados dos filmes de terror. Exponho abaixo, um pequeno trecho de conversa com Zezé, em seu barraco. Trata-se do artista plástico carioca, na faixa dos 45 anos, com cerca de uma década de uso de crack, citado anteriormente.

Zezé - Não. Usuário de crack só tem obrigação com a próxima pedra.

Ygor - Mas, às vezes o credor precisa pagar alguém de onde ele pegou o bloco.

Zezé - A virada não é essa. Geralmente, usuário de crack, ele não usa o que recebe pra pagar o que deve. Entendeu? Ele quer a pedra. Ele deve $R \$ 50,00$, mas ele só tem $R \$ 10,00$, ele não pensa vou pagar $R \$ 10,00$ para ficar devendo só $R \$ 40,00$, não, ele vai querer fazer a pedra porque o corpo exige.

Ygor - Mas aí como é que faz? Fica sempre endividado?

Zezé - Não, ele depois de acordar, quando a gente fala 'acordar' é que quem costuma usar o crack, fica muitas horas sem se alimentar, sem dormir [...] Não tem uma dobra natural no nosso pé? Quando a gente fica três, quatro, cinco dias virados sem dormir, a gente tá caminhando muito, nesse caminhar essas fissuras naturais do nosso pé acabam virando uma ferida. Isso é o pormenor, o pormenor.

Ygor - Ah, certo.

Zezé - Outra. Depois de muitos dias, a gente tem vontade de usar mais e o corpo pede, às vezes quando fica um intervalo sem fumar, o cara pega e descansa, começa a desligar. Você acaba dormindo. Quando vê uma pessoa estirada em qualquer lugar, sem nenhum conforto, deitado, dormindo é porque o corpo desligou.

Ygor - Sei.

Zezé - Sabe quando o combustivel do carro está na reserva. Tem combustivel, mas tá marcando reserva, [...] Você vai subir uma ladeira e aí, no meio da ladeira acabou a gasolina.

Ygor - Sei.

Zezé - E agora? Ou você freia ou deixa o carro descer. É o que acontece com o usuário. Ele apaga, o corpo apaga. 
Todas as imagens que a gente fica vendo e ouvindo parece um filme. É como se você estivesse sonhando acordado.

Ygor - Ah, fica de olho aberto, mas apagado?

Zezé - Não. O consciente fica um pouco inconsciente, psicologicamente falando, entendeu? Você lembra-se de quando você estava dormindo, mas sonhou e quando você acordou você soube que aquilo que você pensava que era realidade, na verdade era um sonho. Isso acontece conosco diariamente, acordado caminhando.

O usuário é perfeitamente capaz de refletir sobre suas adversidades (MALHEIROS, 2013) e a condição de zumbi, ou o estado físico e mental capaz de gerar a atribuição deste termo aos usuários, é uma circunstância específica em uma "caminhada", um apagar.O corpo "exige" a pedra, com uma intensidade proporcional à sequência de dias despertos e dedicados ao crack. Porém, mente e corpo não se apagam necessariamente no mesmo instante e, na medida do cansaço de um, está o esvair do outro. Ao corpo fatigado, sedento e faminto corresponde uma mente propícia a sonhar acordada e despertar, para depois sonhar outras vezes até finalmente desligar. Portanto, o estado comparável ao zumbi, ou seja, aquele no qual se sonha acordado, não diz respeito à totalidade do que chamamos de "Ciclo alerta/sono do usuário de crack", mas apenas a uma parte; mais especificamente àquela correspondente ao estado de movimento do corpo durante o sonho provocado por dias e dias de uso em estado alerta. Atribuir ao usuário de crack a alcunha de zumbi é tomar um estado particular de sua existência cotidiana e tê-lo por totalidade. Este estado é sucedido pelo sono propriamente dito, com o corpo em estado de repouso para em seguida poder despertar com a "mente limpa", ou seja, pronta para um "trago" mais prazeroso. ${ }^{102}$ Neste sentido, corpos e mentes são vistos como um só. À mente alerta, corres-

102 Conforme nos declarou o ex-usuário Antônio, o trago ao despertar, ou seja, aquele dado "com a mente limpa" é mais prazeroso quando comparado àqueles dados apenas para manter-se acordado. 
ponde um corpo em movimento, ao corpo fatigado, corresponde uma mente que sonha acordada. Esta, por vezes, pode estar mais desperta ou mais absorta em um sonho. A percepção embaralhada tem na realidade, o sonho e, no sonho, a realidade. Ele pode despertar e voltar a sonhar por inúmeras vezes e o corpo permanecerá em movimento, a acompanhar o usuário de crack em sua "caminhada". Ao cair definitivamente em um sono profundo, deitado em uma calçada ou mal acomodado em seu barraco, o usuário estará em condições de descansar um pouco mais profundamente, porém, para isso, pagou o preço de ir desfalecendo gradualmente em um longo processo de luta por permanecer um pouco mais semiacordado à custa do consumo de pedras de crack. Assim sendo, o que comumente se chama de binge, o uso de drogas até o completo esgotamento, pode ser mais bem conceituado ao se levar em conta o usuário, seu corpo/mente em um ambiente a proporcionar pedras de crack. Pedras estas obtidas a partir do movimento do "corre" e necessárias para manter um corpo/mente alerta até o embaralhamento de sonho com realidade. Se o uso de drogas em geral nos permite ter uma nova percepção da realidade, o uso do crack permite mesclá-la com nossos sonhos em um ambiente onde tudo parece conspirar para dificultar o descanso.

Figura 39 - Ciclo alerta/sono do usuário de crack

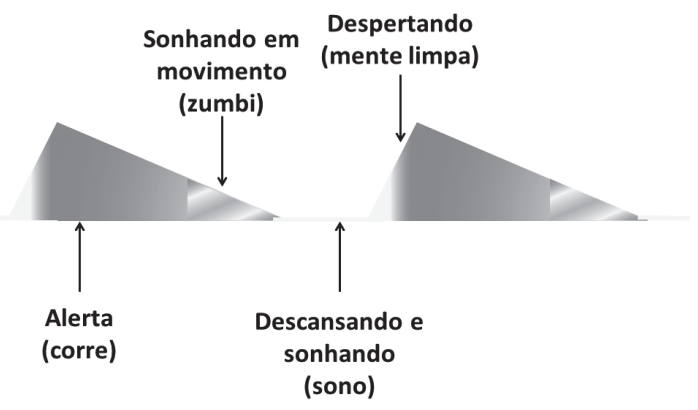

Fonte: Coleção particular do autor. 
A quantidade de pedras fumadas em um dia foi estimada por mais de um usuário em 15 unidades e, os intervalos entre os "tragos" costumavam durar em torno de 15 minutos. Como podemos observar na fala de Zezé: "Vou precisar de outro 'trago', pra compensar o que eu perdi depois de 15 minutos aqui pra dar o 'trago', mas não vou dar neste cachimbo, vou preparar este aqui". Um "bloco" costuma proporcionar seis "tragos" e 15 "blocos", 90 "tragos". Ou seja, 15 minutos de intervalo entre um e outro "trago", são 22 horas e 30 minutos de uso ${ }^{103}$ ininterrupto. Anos de prática parecem proporcionar ao craqueiro uma medida exata de pedras necessárias para um dia satisfatório. Em um ciclo de uso de seis dias, com cinco dias de uso e um de sono, o usuário poderá consumir 90 pedras de crack ou dar 450 "tragos", desde seu despertar até cair no sono novamente. Isto, ao custo de $R \$ 10,00$ a pedra, sai por $R \$ 900,00$. Bancar esta imensa despesa no ambiente da rua, só se torna possível pelas trocas generalizadas existentes do circuito da "treta".

Em um estudo sobre usuários de crack em El Barrio, ${ }^{104}$ na cidade de Nova Iorque, foi encontrada uma frequência de uso de até um "trago" a cada 2,30 minutos . (BOURGOIS, 2006) Ser um "usuário" e não um "nóia” é algo considerado importante pelos nossos interlocutores. O último é vinculado à falta de autodomínio, enquanto o primeiro seria capaz de domar sua vontade e usar a droga em quantidade e frequência controladas. (ZINBERG, 1984)

Mas tudo depende do corpo. Um corpo "virado", dois, três ou mais dias, vai perdendo a capacidade de dominar suas necessidades. A vontade é atributo do corpo descansado e alimentado. Capaz de "fazer seu corre" e não ser "parasita", não ser "frango" como o usuário iniciante, "dragão" incapaz de dar

103 Caso fosse dado pelo usuário, um trago a cada 16 minutos, 90 tragos corresponderiam a exatas 24 horas.

104 Nome dado pelos moradores à região de East Harlem, pesquisada por Bourgois. 
um "trago" comedido e honrar suas obrigações com os parceiros. A reciprocidade, como prática e como valor, é colocada em cheque pelo corpo; este pede a pedra para resistir à fadiga, contra os ditames da "sintonia", sinônimo também de reciprocidade. O equilíbrio só é reencontrado na possibilidade de se ter o sono e depois acordar. A obrigação com o "parça" volta a suplantar a "obrigação com a próxima pedra" que segundo Zezé, seria a única motivação do craqueiro esgotado. Manter-se no domínio da vontade é uma função da maior ou menor fadiga do corpo e da mente.

Isto coloca em discussão como vimos logo acima, a dinâmica do chamado binge de crack, ou seja, seu padrão de consumo crônico, por dias, sem alimentação ou sono, terminando apenas com o usuário exaurido, ou sem a droga. (NAPPO, 2004) Enquanto usa drogas por dias seguidos, o usuário está no "corre", exerce diversas atividades segundo papéis e relações sociais mais ou menos definidos. Ele também se alimenta para auxiliar a controlar a frequência de uso (SILVA, 2000), tanto no início do ciclo, como vimos acima com Zezé, ou mesmo em seu final, antes do sono, como segue abaixo com Antônio, um ex-usuário, com experiência de viver em situação de rua.

Antônio - Um cara chegou pra mim, 'tá [sic] aqui, vou te dar duas, pra você trazer pra mim uma coisa'. Eu falei, 'segura essas duas, eu não tô conseguindo fumar'. Eu não estava conseguindo fumar. Tava com fome. Com fome e com sede [...] Eu tava quatro dias sem comer, chega uma hora que a fome bate e você não tá nem aí. Tô nem aí, pô [...] Aí, ele pagou um lanche. Eu comi. Comi aquele lanche. Me acabei. Deitei e dormi. Dormi até o outro dia.

Ao pensar na frequência de uso encontrada entre os frequentadores da Cracolândia, deve-se levar em conta que ela se altera durante o binge e este uso se dá, na maioria das vezes, em uma roda de crack e não de modo solitário. (VIEIRA, 2010) 
Este modo requereria que o usuário tivesse todo o "maquinário" à sua disposição e o eliminaria do circuito da "treta", da reciprocidade e da "sintonia". Isso lhe roubaria um aspecto fundamental do prazer de fumar, parafraseando Timothy Leary, aquela sensação de cumplicidade prazerosa daqueles que compartilharam a mesma pedra imprimindo bons sentimentos uns nos outros. (LEARY, 1999, p. 164) Se não considerarmos essa dimensão do prazer, nossa compreensão das motivações do usuário fica restrita apenas ao uso do crack, ou mais errôneo ainda, ao alívio da fissura.

Estes e outros aspectos da realidade vivida pelo craqueiro só podem ser observados no campo e ficam inacessiveis às pesquisas com usuários institucionalizados, ou convidados a dar entrevistas a pesquisadores em ambiente acadêmico. Vimos no decorrer deste livro como, nas cenas de uso, os usuários escolhem entre diversas qualidades da droga e múltiplos ambientes para manipularem os efeitos ou "brisa", segundo as diversas oportunidades abertas pelos seus múltiplos estados corporais em interação com ambientes variados e seus inúmeros usuários. Sabemos que os padrões de uso passam por diferentes gradações na carreira de cada usuário e ao mesmo tempo dependem dos imponderáveis do cotidiano, variando do padrão controlado ao "se deixar levar".

Acima de tudo, deve-se atentar para a maneira como as práticas de uso se enquadram em uma ritualidade complexa de trocas materiais e simbólicas, variável com a disponibilidade da droga, ambiente físico, maior ou menor prestígio dos envolvidos e as possiveis ameaças que possam se apresentar, provenientes de diferentes fontes, mas sempre presentes no contexto da ilegalidade. Os efeitos do uso do crack, denominados pelos usuários de "brisa", dependem do ambiente de consumo, e podem variar desde sensações agradáveis e prazerosas, acompanhadas de disposição para as mais diversas atividades, sejam 
elas voltadas ao trabalho ou à sociabilidade, até a "paranoia", onde prevalecem movimentos repetitivos e o desprazer. Entre estas possibilidades, com suas múltiplas gradações, os usuários manipulam o corpo, o ambiente e a droga, segundo sua vontade e as possibilidades que se oferecem. 


\section{JAMAIS FOMOS ZUMBIS: DUAS EXPERIÊNCIAS DE MUDANÇA NO CONTEXTO SOCIAL DO USUÁRIO DE CRACK}

O Programa de Braços Abertos (DBA) e os campeonatos de futebol realizados pela prefeitura paulistana revelaram-se como duas iniciativas administrativas com importante impacto sobre o contexto social dos usuários de crack da região central da cidade. Elas nos mostram como os controles sociais formais mais razoáveis, como o cumprimento de horários e comparecimento a certas atividades, podem interagir perfeitamente com rituais e sanções responsáveis por estabelecer controles sociais informais. Isto ajuda a compor uma série de pressões no sentido de assumir um padrão mais discreto de uso em um cotidiano estruturado, marcado pela hierarquia e submissão à autoridade formal.

\section{o Programa De Braços Abertos: ruptura, continuidade e radicalização da redução de danos}

Amplamente escudado nos princípios da redução de danos, o Programa De Braços Abertos (DBA) "foca em pessoas que seguem usando drogas”. (IHRA, 2010, p. 1) A única posição defendida pela Associação Internacional de Redução de Danos em desacordo com o programa municipal é a de privilegiar pequenos ganhos para muitos ao invés de grandes ganhos para poucos, por acertadamente considerar os primeiros mais impactantes que os últimos. Ao contrário desta posição, o Programa DBA vem desde o início de 2014,gerando grandes ganhos para muitos. ${ }^{105}$

105 Aliás, praticamente a integralidade da posição oficial da Associação Internacional de Redução de Danos, conforme procuramos resumir abaixo, se encontra aplicada no programa da Prefeitura do Município de São Paulo (PMSP):

1. Aceitação do fato de que muitas pessoas não querem ou não conseguem parar de usar drogas; 
"Quem inventou o Braços Abertos fui eu", esta frase foi ouvida por este pesquisador ao conversar com um beneficiário, termo utilizado pela Prefeitura do Município de São Paulo (PMSP) para se referir aos incluídos no Programa DBA. Trata-se de um usuário de crack de trato razoavelmente dificil, ele às vezes mostra-se violento, mas orgulha-se de ter participado das reuniões preparatórias para a implantação do Programa DBA com o prefeito Fernando Haddad. Antes do Programa, os craqueiros viviam na Cracolândia sob o peso do estigma do zumbi morto vivo. (BOES, 2011) Infelizmente, este estigma ainda se encontra presente em publicações recentes, conforme observamos a seguir:

2. Levar em conta idade e gênero;

3. A não necessidade de tratamento para a maioria dos casos;

4. A oferta de opções que minimizem os riscos de continuar usando;

5. A oferta de serviços e informações que visem manter os usuários saudáveis;

6. Trazer benefícios aos usuários, suas famílias e a comunidade;

7. Forte compromisso com saúde pública e direitos humanos;

8. Redução dos riscos e consequências do uso (não somente do crack, mas também do álcool);

9. Alto impacto na saúde individual e comunitária;

10. Intervenções facilitadoras e não coercitivas;

11. Servir as necessidades dos usuários onde eles estão ou vivem;

12. Aceitar as pessoas como elas são e evitar julgar comportamentos;

13. Se opor a estigmatização deliberada dos usuários;

14. Garantia de direito a atendimento de saúde, serviços sociais e direito ao trabalho;

15. Direito de não ter prisão arbitrária, tratamento cruel ou desumano;

16. Questionamento da discriminação contra pessoas que usam drogas;

17. Questionamento do abuso de práticas policiais;

18. Questionamento de políticas públicas e leis restritivas;

19. Encorajamento do diálogo, do processo consultivo e do debate.;

20. Participação das pessoas que usam drogas e outros envolvidos em suas comunidades nas decisões. 
Os usuários, reunidos em bandos, começaram a assombrar primeiramente as noites de São Paulo. Eram amontoados de gente suja, descabelada, que vagavam catatônicos no que pareciam guetos de morte. Quem acompanha as histórias de ficção sobre zumbis viu logo uma associação muito fácil entre os usuários e os 'mortos vivos' das sagas do cinema e da literatura. (ROTENBERG, 2013, p. 13)

Após a implementação do DBA esta visão estereotipada começa a perder importância para uma nova maneira de encarar o usuário de crack, e de uma forma mais humana. Até o melancólico término da gestão Kassab frente à PMSP, a certeza corrente era da incapacidade generalizada entre os usuários de crack - retratados como zumbis - de exercer sua vontade. O DBA, gestado em encontros destes usuários diretamente com o prefeito da cidade de São Paulo, veio propor justamente o reconhecimento desta vontade.

Os encontros entre os beneficiários e o prefeito permaneceram até o término de seu mandato, ampliados pela participação de lideranças de movimentos sociais, entidades de classe e técnicos responsáveis por um programa em permanente construção. Seu início, em meados de 2013, foi marcado pela determinação em se contrapor às políticas pautadas pela repressão e pela internação em comunidades terapêuticas, muitas vezes de forma involuntária e até mesmo compulsória, levadas à frente pelo governo do Estado de São Paulo, particularmente na gestão Geraldo Alckmin.

Como vimos, o DBA é um programa em permanente construção e esta construção data da elaboração do plano de governo sob o lema "Um tempo novo para São Paulo" do então candidato a prefeito Fernando Haddad. Neste plano é possível vislumbrar o aspecto estruturante do Programa DBA, ou seja, a dimensão intersetorial da "Política sobre o Crack" que se dedicou a "Implementar uma ação intersetorial (saúde, assistência social, emprego e renda, educação, ambiente urbano, cultura, 
lazer, esportes etc.), desenvolvida de forma integrada com o Governo Estadual e com o Governo Federal, por meio de seu Programa "Crack é Possivel Vencer". (UM TEMPO, 2012)

Assim, um plano de intervenção positiva no bairro da Luz foi traçado no sentido de levar cuidado, assistência e dignidade aos usuários de crack. Um importante sinal de seu caráter diferenciado foi ter a coordenação do Grupo Executivo Municipal (GEM), responsável pela concepção e implantação do programa, sob a responsabilidade da área técnica de saúde mental, álcool e drogas da Secretaria Municipal de Saúde (SMS). Neste sentido, os beneficiários do DBA têm sua situação cotidiana considerada e avaliada prioritariamente sob a perspectiva da saúde e da assistência. Em primeiro plano encontram-se - além da SMS - a Secretaria Municipal de Assistência e Desenvolvimento Social (Smads), a Secretaria Municipal de Direitos Humanos e Cidadania (SMDHC), a Secretaria Municipal do Desenvolvimento, Trabalho e Empreendedorismo (SDTE) e a Secretaria Municipal de Segurança Urbana. Esta última com presença decrescente na gestão local do programa, segundo declarações de técnicos presentes desde sua implantação, com quem pudemos dialogar. Porém, acreditamos que pelas pressões políticas por parte da mídia, que passou a chamar o Programa DBA de "bolsa crack", o secretário municipal de segurança pública, Benedito Mariano, acabou sendo chamado a coordenar o DBA.

O DBA nasce sob o espírito da $5^{\mathrm{a}}$ Conferência Municipal de Políticas de Atenção às Drogas (Compad), realizada pela SMDHC, pelo GEM e o Conselho Municipal de Políticas Públicas de Drogas e Álcool (Comuda). A conferência foi precedida por reuniões preparatórias abertas feitas por representantes dos três entes municipais supracitados, nas regiões leste, oeste, sul e central da cidade. A importância da articulação intersetorial foi uma das propostas da conferência, do mesmo modo como a composição do "Consultório na Rua" com "redutores 
de danos, equipe de saúde mental articulada com assistência social". (PREFEITURA DE SÃO PAULO, 2013, p. 5) Também foi destacada a importância de uma ideia de cuidado não focada apenas na internação, a promoção do matriciamento entre as redes responsáveis pelo atendimento aos usuários de drogas e a capacitação dos profissionais ligados à política sobre crack, álcool e outras drogas. Nas pré-conferências sobre a saúde mental, DST/HIV/Aids e saúde da população negra, as preocupações existentes no desenho do Programa DBA estavam presentes também, por exemplo, como trabalhar em uma estratégia de redução de danos, os Consultórios na Rua e a ação intersetorial com presença de cultura, esportes, geração de renda e emprego. (PREFEITURA DE SÃO PAULO, 2013) Após a $5^{\circ}$ Compad, o Comitê Intersetorial da Política Municipal para a População em Situação de Rua (Comitê Poprua) deu prosseguimento às discussões sobre o Programa DBA até sua implementação. $\mathrm{Na}$ ata de sua quinta reunião extraordinária podemos ler:

Sra. Cormarie (SMS) e o Sr. Odimar Edmundo dos Reis (SMS) comentam a respeito do equipamento da Helvetia, que é um equipamento Intersetorial, coordenado pela saúde, mas com ações de diversas secretarias assistência social, esportes e outras. Que tem (sic) como objetivo escutar e fazer vínculo na perspectiva do trabalho de redução de danos trabalhando principalmente com usuários de Crack. Relata a importância do espaço como referência para que as pessoas possam frequentar e começar a planejar novas perspectivas para suas vidas e como estratégia para atrair as pessoas aos locais oferecem refeições rápidas, possibilidade de banho, atividades lúdicas, rodas de conversas, rodas de samba, oficinas, terapias alternativas como acupuntura, mencionam o trabalho de um médico psiquiatra que anda como palhaço pelo espaço, etc. Destacam que não é um lugar de encaminhamentos, mas sim de construção de vínculos. Estão com o movimento de 400 pessoas por dia e já fizeram 180 planos terapêuticos. Comentam que a equipe conta com o apoio da comunidade local e que está sendo um 
trabalho conjunto de toda a sociedade. Informaram que o prefeito solicitou a construção de novo equipamento na mesma direção e as equipes de governo planejam utilizar o espaço no Parque Dom Pedro para esta finalidade e já estão construindo a estratégia para abertura nos próximos dias. (PREFEITURA DE SÃO PAULO, 2013, p. 2-3, grifo nosso)

É importante salientar que o número de pessoas consideradas como constituindo o movimento diário no equipamento do Programa DBA, 400 pessoas, será mantido como meta de beneficiários a serem atendidos na Frente de Trabalho, embora, atualmente, este número tenha chegado a mais de 500 beneficiários. ${ }^{106}$ (PREFEITURA DE SÃO PAULO, 2015b) Os vínculos com os usuários de crack e o apoio da comunidade local se revelarão de especial importância no processo posterior de construção do Programa, com a participação dos futuros beneficiários e sua transferência dos barracos para os hotéis. Nesta construção ficou claro a ligação de parcela maciça dos futuros beneficiários com a região. Muitos não conheciam outro bairro na cidade além do bairro da Luz e outros tantos estavam lá há mais de uma década, sem laços importantes com outros territórios.

Se alguma experiência de política pública pode ser apontada como responsável por influenciar o programa paulistano, esta experiência é a da Prefeitura Municipal de São Bernardo do Campo (SBC). Ao secretário municipal de direitos humanos e cidadania da cidade de São Paulo, Rogério Sottili ${ }^{107}$ foi dada a orientação pelo prefeito Fernando Haddad para que visitasse e conhecesse a iniciativa da prefeitura da região do ABC paulista, berço do petismo. Esta cidade é governada pelo petista Luiz

106 Este número seria dobrado em 2017, expectativa frustrada pela derrota eleitoral de Haddad.

107 O secretário seria substituído pelo ex-senador Eduardo Suplicy no início de 2014, mas permaneceria na SMDHC, como secretário adjunto. Posteriormente, retornaria ao governo federal. 
Marinho, ex-ministro do governo Lula e possui uma política de drogas baseada em Repúblicas Terapêuticas (RT), espaços de moradia transitória, assim como em projetos terapêuticos e de geração de renda desenvolvidos na rede Centros de Atenção Psicossocial (CAPS). Outras características da atuação em São Bernardo (PIERRO, 2012) visíveis no caso paulistano são as políticas intersetoriais, os Consultórios de Rua e a preocupação dada à manutenção de vínculos entre profissionais da prefeitura e usuários de crack. Uma importante diferença está na criação, em SBC, do cargo de acompanhante para proporcionar 24 horas diárias de atenção ao usuário vinculado à RT, ausente em São Paulo.

O Programa DBA, esta ação intersecretarial, foi planejado para ofertar abrigamento, tratamento de saúde, alimentação, atividade ocupacional, capacitação profissional e auxílio financeiro aos beneficiários incluídos na execução de serviços de zeladoria nas ruas e teve início dia 14 de janeiro de 2014 . Após dois dias, todos os 147 barracos distribuídos entre as ruas Dino Bueno e Helvétia - local onde hoje se centraliza a Cracolândia - haviam sido retirados. A não construção de novos barracos no local foi pactuada entre a PMSP e os futuros beneficiários do DBA. A adesão ao programa foi da totalidade dos ocupantes dos barracos e se deu nos dias anteriores, ao serem contratados pelo Programa Operação Trabalho (POT) da SDTE para trabalharem em atividades de zeladoria na região, ocupação pela qual passaram a receber um auxílio financeiro no valor de $R \$ 15,00^{108}$ por dia de trabalho, incluindo os finais de semana para os assíduos. Esta forma de contratação é uma adaptação do POT e compreende um valor de auxílio pecuniário mensal de $R \$ 450,00$ por 20 horas semanais de trabalho, ou 4 horas diárias nos chamados dias úteis. O POT prevê o investimento total de um salário mínimo e meio por beneficiário. Como custo para a PMSP há também o pagamento

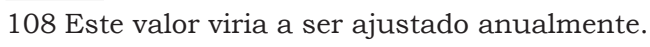


das vagas em hotéis da região e alimentação correspondente a três refeições diárias no restaurante Bom Prato, programa do governo estadual responsável por fornecer refeições a um real em restaurante gerido por Organização Social, localizado na rua Dino Bueno. Também há cursos de capacitação ofertados a partir de aptidões e demandas dos beneficiários e o pagamento da equipe de técnicos e orientadores, assim como dos gestores do serviço: a organização não governamental Brasil Gigante, a serviço da SMDHC. Em setembro de 2014, a Brasil Gigante foi substituída pela Associação de Desenvolvimento Econômico e Social às Famílias (Adesaf) após processo licitatório.

\section{A frente de Trabalho e o Trio}

A Adesaf gerencia a frente de trabalho, parte do DBA. Até então dedicada à gestão de projetos para crianças e adolescentes, esta OSCIP foi contratada após processo licitatório para gerir o programa. Em contato com a gestora anterior, a ONG Brasil Gigante (OBG), pudemos acompanhar o trabalho das equipes no trecho, como é chamado o caminho percorrido por cada equipe nos arredores do bairro dos Campos Elíseos.

Após acordarem e sairem do hotel, os beneficiários se dirigem ao restaurante Bom Prato, localizado na rua Dino Bueno para tomarem o café da manhã. A entrada no restaurante é possibilitada por um crachá distribuído pelo orientador social a cada um de sua equipe de 20 beneficiários. Dificilmente a equipe estará completa, os ausentes serão objeto de busca ativa por parte dos 44 orientadores socioeducativos da Smads e agentes comunitários de saúde da SMS. As informações sobre a ausência no trabalho, para a posterior busca ativa, são obtidas por estes profissionais após o café da manhã, no local de saída das equipes. Em seguida, os agentes sociais da Smads e agentes comunitários de saúde responsáveis por cada grupo de 20 beneficiários se dirigem aos hotéis para visitá-los e verificar os motivos da ausência na frente de trabalho. Entre às 13 e 14 
horas, o trio composto pelos agentes sociais da Smads, agentes comunitários de saúde da SMS e orientadores sociais da SMDHC se reúne para discutir as diversas demandas surgidas. Esta rotina passou a ser implementada pouco mais de um mês após o início dos serviços de zeladoria feitos por parte dos beneficiários. Antes, cada trio, como é chamado o grupo responsável por uma equipe, se encontrava e resolvia as demandas individuais de modo informal. Os agentes comunitários de saúde são os únicos não disponiveis na proporção de um por grupo de 20 pessoas, mas apenas um por hotel onde se hospedem beneficiários.

A busca ativa é feita dentro dos hotéis com os membros do trio indo de porta em porta. Ao final do mês de fevereiro de 2014, apenas 200 entre 429 participantes do DBA se dedicaram aos serviços de zeladoria, alguns jamais apareceram para trabalhar, outros desistiram pelos mais diversos motivos, como os de saúde. Em meados de abril, este número havia subido para 293 beneficiários participando dos serviços de zeladoria ao menos uma vez naquele mês. Há casos de nomes que constavam nas listas das equipes de 20 beneficiários, mas as pessoas nunca apareceram para trabalhar, assim como o número de inscritos na primeira fase do programa ressurgiram após três meses de sua implantação. Em todo caso, não há exclusão do programa, dada sua baixa exigência, ou exigência apropriada. Mesmo com meses de ausência, eles estão incluídos.

Os membros das equipes citadas acima, originalmente trabalhavam apenas em um mesmo hotel. Contudo, devido à necessária flexibilidade exigida pelas características dos beneficiários, há uma considerável flutuação deles entre os apartamentos e mesmo entre os hotéis. Isto se dá pelos mais variados motivos, desde separações de casais, passando pelo desejo de ter uma acomodação melhor, até a simples curiosidade de conhecer e se alojar em quarto ou hotel diferente. Assim, os trios devem dar conta de 20 beneficiários distribuídos nos mais va- 
riados hotéis. Isto marca um dos pontos fortes do programa: o atendimento integrado, individualizado e integral ao beneficiário, proporcionado pelo trabalho de profissionais ligados às áreas de saúde, assistência e trabalho em contato diário.

Os antigos moradores dos barracos, por sua vez, tentam adaptar o quarto de hotel à vida costumeira no barraco e, ao mesmo tempo, mudam o estilo costumeiro de ocupação de um hotel para melhor adaptá-lo ao seu modo de vida em transição. Por exemplo, ocupam os corredores e escadas para conversas e lazer, flutuam entre os quartos e prédios e alugam vagas para terceiros nos finais de semana, quando não há acompanhamento dos agentes sociais da Smads. Estes estão presentes todos os dias úteis na portaria e procuram estabelecer certo controle sobre a ocupação dos quartos. A flutuação não se dá livremente, mas por via de pedidos às agentes sociais e particularmente a uma assistente social com larga experiência na região. Esta assistente social conhece pelo nome ou apelido praticamente a totalidade dos beneficiários que são antigos moradores ou frequentadores assíduos da Cracolândia.

Existe uma preocupação dos técnicos, particularmente da saúde mental, em garantir que nos encaminhamentos dos beneficiários, todos se atentem às diferenças entre os serviços oferecidos pela PMSP e pelo Governo do Estado, bem como da importância de se referenciarem nos serviços municipais e não nos oferecidos pelo poder estadual. Como vimos acima, grosso modo poderíamos considerar os serviços estaduais como dando certa prioridade à internação em Comunidades Terapêuticas (CT), enquanto a PMSP priorizaria os CAPS. São cinco CAPS na rede de abrangência do Programa DBA, dois CAPS-AD III, um CAPS infantil, um CAPS adulto e o Centro de Referência de Álcool, Tabaco e Outras Drogas (Cratod), este último também possuindo um CAPS, além de outros serviços. Isto não impede a abordagem de beneficiários, assim como dos demais frequentadores da Cracolândia, por agentes sociais do Instituto Mensageiros para 
encaminhamento a comunidades terapêticas, através do Programa Recomeço (PR), do governo estadual. Porém, caso um beneficiário seja abordado e necessite de tratamento ambulatorial, ele é normalmente conduzido pelos agentes sociais do PR aos CAPS da prefeitura. Da mesma forma, caso algum beneficiário do Programa DBA chegue, juntamente com a equipe multidisciplinar em contato com ele, à decisão por uma internação em clínica de recuperação ou CT, ele será encaminhado ao PR. Este tipo de relacionamento existia antes da implantação do Programa DBA inclusive, após sua inauguração foi objeto de acordo formal entre os entes estadual e municipal.

Por estarem hospedados em hotéis e trabalhando meio período, os beneficiados são obrigados a se adaptar ao novo ambiente físico, mas também procuram se servir de novas possibilidades abertas pelo DBA. Assim, nas semanas iniciais do programa, chegaram a alugar seus quartos para encontros e pernoites para aqueles frequentadores da Cracolândia não incluídos no Programa DBA, assim como vender uniformes a $R \$ 50,00$ e botas $R \$ 60,00$, a negociar cartões de alimentação e até os documentos de identidade retirados por Smads. Todos estes fatos são de conhecimento dos gestores do DBA - principalmente da SDTE e Smads - e em resposta eles procuram os mecanismos de controle possiveis de serem adotados. Por exemplo, uma carteira de identificação dos beneficiários foi confeccionada, embora esbarre na aversão de parte deles por fotografias, devido a uma parcela ter pendências com a justiça. Isto levou Smads a procurar a defensoria pública do estado, para tratar de assessorar juridicamente aqueles dispostos a resolver suas altercações jurídicas.

\section{A tenda e o fluxo}

O Programa DBA possui sede própria independente da sede alugada inicialmente, pela OBG, no Largo Coração de Jesus, localizando-se a dois quarteirões desta, quase na esquina das 
ruas Helvetia e Cleveland. É uma construção modesta, separada da rua por uma grade e dotada de portão também gradeado. Possui uma tenda de aproximadamente $25 \mathrm{~m}^{2}$ e uma pequena edificação com sala de reuniões, cozinha e banheiros para os funcionários e outros dois banheiros usados normalmente pelos beneficiários, além dos demais usuários de crack frequentadores do "fluxo" - local de uso de crack localizado, por vezes, em frente à Tenda. Lá trabalham cinco profissionais da administração direta, responsáveis por gerenciar todas as ações vinculadas à SMS. Esta sede serve de ponto de apoio para três equipes do Programa de Agentes Comunitários de Saúde (PACS), compostas por dez agentes cada e um enfermeiro por equipe. A "Tenda" é um local para uso das equipes de saúde e assistência e também uma área de lazer para os frequentadores da Cracolândia e demais usuários de crack frequentadores do "fluxo".

O "fluxo" é uma aglomeração humana com dezenas ou mesmo centenas de usuários de crack a depender de diversos fatores, desde climáticos, passando pela repressão policial ao tráfico, até a proximidade, ou não dos dias de pagamento, não só dos beneficiários como dos trabalhadores em geral. Ele já existia muito antes da criação do Programa DBA. O "fluxo" esteve contido em uma pequena área de $1000 \mathrm{~m}^{2}$ entre o DBA e o ônibus do Programa Crack, é Possível Vencer, o local foi alvo de melhorias como a colocação de floreiras, ${ }^{109}$ tornando-se uma praça.

Isto posto, podemos voltar nossa atenção à sede do Programa DBA. Esse programa encontra-se localizado em frente ao "fluxo" da esquina das ruas Helvetia e Cleveland e dele separada por uma tela de metal e um portão, também de tela, permanentemente aberto. A identificação do local é feita por um desenho sobre um pano com o nome e logo do Programa DBA

109 No segundo semestre de 2013, novos barracos foram erguidos no "fluxo". Neles há constante venda de crack e a GCM não adentra mais esta área para promover prisões. 
amarrado entre duas colunas da tenda e voltado para a rua. No período diurno, há, por vezes, um esforço para manter o "fluxo" em frente à sede do Programa DBA feito pela Guarda Civil Metropolitana (GCM). Isto permitia sua filmagem por câmeras localizadas no ônibus supracitado, estacionado na rua Cleveland. Estas filmagens eram utilizadas para "intervenções cirúrgicas" (PADILHA, 2014) da polícia no "fluxo", termo utilizado pelo candidato petista ao governo estadual, Alexandre Padilha, para referir-se ao uso de informações obtidas pelas câmeras para repressão ao tráfico de crack preservando o usuário da violência policial. As imagens deveriam também servir para denunciar possiveis arbitrariedades do poder público.

$\mathrm{Na}$ sede, as equipes das secretarias municipais da saúde e assistência trabalhavam em mesas sob a tenda, compartilhando o mesmo espaço com os usuários de crack, estes, conversavam, jogavam tênis de mesa, não poucas vezes com alguém das equipes e assistem televisão, geralmente deitados sobre os mesmos cobertores e colchões usados nas calçadas, ao lado do equipamento. Não poucos usuários se aproveitavam da sombra e segurança ali proporcionadas para dormir. Assim, temos um equipamento público aberto, com formas de ocupação mutável e disponível; contíguo ao principal local de uso de álcool e drogas da Cracolândia, o "fluxo". Aqueles lá presentes podem, a qualquer momento adentrar, pelo portão constantemente aberto para buscar água em uma mangueira localizada ao lado da televisão, usar um dos dois banheiros destinados a servi-los, se dirigir à lavanderia com cinco tanques de lavar roupa localizada ao final de um pequeno corredor de frente para o portão, ou aos equipamentos de ginástica dispostos sob um gazebo no mesmo corredor. Temporariamente, houve uma equipe da Secretaria Municipal de Esportes e Lazer no local, ela foi desalojada da Praça Coração de Jesus após a destruição do equipamento lá localizado em dezembro de 2013. Segundo informações dos funcionários desta secretaria, provisoriamen- 
te alocados na sede do Programa DBA, isto se deu quando, certa noite, os membros da GCM, responsáveis pela segurança do local deixaram de exercer sua função de cuidar daquele equipamento sem darem aviso prévio à Secretaria Municipal de Esportes e Lazer. Nessa mesma noite, os frequentadores da Cracolândia teriam pulado a grade de isolamento da praça e destruído as instalações, levando até as janelas da pequena edificação lá presente. Toda área foi reformada por uma empresa de seguros com sede na região e recebeu um posto da Polícia Militar, assim como quadras para prática de futebol de salão. As equipes de futsal, compostas por usuários de crack estudadas no próximo capítulo deste livro, se utilizavam do local para treinos e campeonatos. Podemos visualizar um cartaz de um destes campeonatos abaixo:

Figura 40 - Cartaz Festival de Futsal

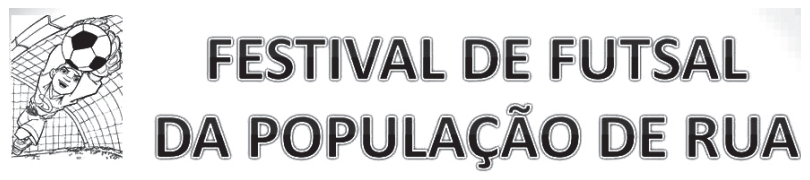

Dia 02/08/2014 - das 9h às $15 \mathrm{~h}$ LOCAL: Quadra do Largo Coração de Jesus

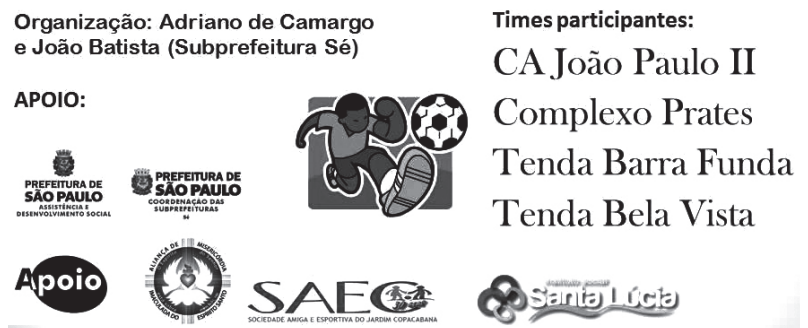

Fonte: https: / $/$ www.facebook.com / photo.php?fbid=779642898723391\&set=a .183850888302598 .38182 .1000003306417148 type=1\&theater.

No cartaz do Festival de Futsal, vemos figurar como times participantes, duas equipes objeto de nossa pesquisa etnográ- 
fica, a Tenda Barra Funda e a Tenda Bela Vista. Um dos organizadores do torneio é também o orientador socioeducativo destas duas equipes. Entre os apoiadores, encontramos Smads e as quatro organizações sociais responsáveis pela gestão dos equipamentos conveniados, Centros de Convivência e Centros de Acolhida.

O Programa DBA funciona de domingo a domingo, portanto existe plantão de cinco profissionais dos CAPS Sé e Complexo Prates aos finais de semana. Porém, verificamos a ausência de acompanhamento entre às 22:00 e 8:00 horas. Esta lacuna possibilitou, no início do mês de abril de 2014, que uma gestante em início de trabalho de parto no "fluxo" fosse levada por viatura da Polícia Militar durante a madrugada. Isto causou sérias complicações quanto à guarda da criança, principalmente pelo parto ter sido realizado na Santa Casa de Misericórdia, hospital considerado pelas assistentes sociais como contumaz em retirar a guarda de filhos de usuários de crack em situação de rua, somado ao fato da mãe não possuir ainda documentação. Isto foi devido à falta de plantão, porém, existem vários outros problemas quanto ao atendimento aos usuários de drogas em toda cidade.

Para sanar a situação, os 11 mil profissionais da Rede de Atenção Psicossocial (RAPS), ${ }^{110}$ além dos de hospitais, CAPS e Unidades Básicas de Saúde (UBS) estão sendo qualificados por intermédio de cursos de formação. A atenção, a abordagem e o cuidado em relação às pessoas que fazem uso abusivo de substâncias psicoativas são todas áreas problemáticas e os profissionais são frequentemente denunciados por maus tratos. Nas palavras da médica responsável pelo Programa DBA em uma reunião de prestação de contas, de abril de 2014, esta afirma que o Programa DBA “parte do princípio de que o uso abusivo

110 A RAPS tornou-se parte de uma política nacional de saúde a partir do Decreto n. ${ }^{\circ} 7508 / 11$. Este Decreto tem por base uma "perspectiva territorial" (BRASIL, 2011) e comunitária a partir de ações intersetoriais. 
de substância psicoativa se trata de uma doença e que todo cidadão no território é um cidadão com direitos”.

Certamente, nos parece mais desejável considerar o usuário um doente ao invés de criminoso, já que isto torna estas pessoas alvo de políticas públicas de saúde, ao invés da mera punição. Na mesma perspectiva, isso é também preferivel ao tratamento da questão como desvio moral, pelo estigma daí decorrente. Porém, considerar o uso de drogas sob a ótica da saúde abre espaço para certo exercício exagerado do poder médico, particularmente se considerada a legislação vigente sobre os direitos das pessoas portadoras de transtornos mentais. O profissional médico necessita apenas estar devidamente registrado no Conselho Regional de Medicina do estado onde se localize o estabelecimento em que irá ocorrer a internação, para poder fazê-la a pedido de terceiro e "sem o consentimento do usuário". (BRASIL, 2001) Ao se tratar o uso de crack como constituindo uma epidemia, passa-se a considerar o consumo coletivo de uma substância de modo semelhante a uma doença infectocontagiosa, onde ocorre transmissão de hospedeiro para hospedeiro ou, em nosso caso, de usuário para usuário. Em decorrência, existe então a possibilidade de advogar a favor da necessidade de realizar um saneamento do ambiente, como feito décadas atrás, no caso da hanseníase e da tuberculose, retirando-se os doentes/hospedeiros para locais remotos até seu pronto restabelecimento ou, no caso da hanseníase, de modo perpétuo. A internação compulsória dos usuários de crack nos parece seguir esta lógica. De modo similar, o usuário de crack é também visto como possivel transmissor, através do compartilhamento de cachimbos e relações sexuais, da mais variada gama de enfermidades como Aids, hepatite $\mathrm{C}$ e tuberculose. Assim, o usuário de crack, transmutado em hospedeiro capaz de transmitir uma doença contagiosa sob epidemia, torna-se objeto da "intervenção do Estado na liberdade individual, sob o pretexto de preservar a saúde pública". (LIMA, 2009, p. 84) À semelhança de certos usuários de crack submetidos a múlti- 
plas internações durante sua vida, "as pessoas diagnosticadas como portadoras de doenças contagiosas eram condenadas ao isolamento para toda a vida”. (LIMA, 2009, p. 87) O uso de crack e por decorrência a própria liberdade do usuário é transformada em perigo à saúde pública.

\section{O Programa DBA: integração do invés de gentrificação}

"Hoje à noite, eu vou poder dormir com os dois olhos"111

As políticas públicas procuram soluções para questões atuais, aquelas perceptíveis no ato de seu acontecimento e são colocadas em prática, testadas na dureza do jogo político. Um governo deve ser capaz de responder a esta urgência. O Programa DBA respondeu a seu modo e em um ambiente ainda marcado pelo pânico moral gerado durante a eleição presidencial de 2010, no qual medidas punitivas eram as mais condizentes com o pragmatismo eleitoral.

Um ano após a deflagração da Operação Dor e Sofrimento, a cidade de São Paulo mudou sua política. A anterior pode ser resumida nas palavras, que hoje temos dificuldade em acreditar que um coordenador de Políticas sobre Drogas da Secretaria de Estado da Justiça e da Defesa da Cidadania, como era Luiz Alberto Chaves de Oliveira, pudesse proferir:

A falta da droga e a dificuldade de fixação vão fazer com que as pessoas busquem o tratamento. Como é que você consegue levar o usuário a se tratar? Não é pela razão, é pelo sofrimento. Quem busca ajuda não suporta mais aquela situação. Dor e o sofrimento fazem a pessoa pedir ajuda.

Nosso senso comum costuma definir o ser humano como um animal dotado de razão. Como ser racional, o homo sapiens

111 Lucas - beneficiário do Programa DBA. 
é produtor de cultura dem oposição às plantas e aos demais animais. Impor sofrimento a um animal é considerado crime e causa imensa revolta, principalmente, ao tratar-se de animais domésticos como cães e gatos. Um governante disposto a impor sofrimento a bichos de estimação seria alvo, no mínimo, da incompreensão dos cidadãos. Neste sentido, os usuários de crack se encontravam, no momento da deflagração da Dor e Sofrimento, para o Governo do Estado de São Paulo, com um status inferior não apenas ao do cidadão, mas do animal irracional.

Neste quadro surge o Programa DBA. Para elaborar a nova política e dar início ao Programa DBA, com a instalação de um equipamento público na rua Helvétia quase esquina com Cleveland, o prefeito Fernando Haddad fez, durante o ano de 2013, diversas visitas informais à Cracolândia e estabeleceu vínculo com alguns usuários de crack e lideranças, como o usuário autor da frase "Quem inventou o Braços Abertos fui eu". A partir destas conversas informais foi se desenhando um grupo de lideranças que passou a ser convidado a auxiliar na definição e planejamento das ações do Programa. Deste modo, foram incluídos no programa reivindicações de habitação, lazer, assistência e trabalho, onde inicialmente se preocupava apenas com a saúde. Por uma escolha metodológica, foram cadastrados primeiro os ocupantes dos barracos, eles, em sua quase totalidade, eram também frequentadores do "fluxo". Como um mesmo barraco era compartilhado por inúmeras pessoas que o utilizavam para pequenos descansos, pode-se considerar que quase o conjunto dos residentes no território foi acolhido desde o primeiro momento. Havia também, na pequena favela formada na Cracolândia durante o segundo semestre de 2013, pessoas não usuárias de crack e sequer de álcool que tiveram sua inclusão pelo critério de encontrar-se em situação de rua. Após serem alocados nos hotéis, os beneficiários passaram a ter contato diário com os funcionários da saúde, assistência e trabalho. Os agentes sociais de Smads através de um Plano Individual 
de Atendimento (PIA) começaram a monitorar e dar encaminhamento às necessidades dos beneficiários como: retirada de documentos, encaminhamento de problemas legais e acesso à creche ou escola para seus filhos. ${ }^{112}$ Seu tempo de permanência nos hotéis e no Programa DBA será determinado pelos agentes sociais da PIA juntamente com o beneficiário. Os contratos com os hotéis foram feitos por seis meses devido às características do POT e a necessidade de licitação. O período de seis meses é também um norte utilizado na assistência social para a construção do PIA, considerando as particularidades de cada caso, este tempo pode até ser suficiente para uma saída "qualificada" do beneficiário da rede. No Programa DBA alguns já saíram para a "autonomia". Um caso emblemático foi de um membro do PCC no local, encontrado pela família após assistirem na televisão reportagens sobre o Programa DBA. Está prevista a possibilidade de muitos necessitarem de mais de seis meses para poderem retornar à família e mesmo de outros possivelmente estarem fadados a manter vínculo indefinido com a rede assistencial.

Como o Programa DBA foi desenhado pelos próprios usuários de crack da localidade, ele possivelmente não se preste a ser replicado em outras regiões da cidade, muito menos sirva de modelo para outras cidades brasileiras. Porém, seu maior trunfo, a participação dos usuários de crack na concepção e avaliação periódica do programa, em encontros com o próprio prefeito da cidade parece ser uma característica replicável em outros contextos. A pactuação das decisões na área dos serviços municipais prestados por Smads não é uma característica exclusiva do Programa DBA. Um caso pouco anterior ao início do programa foi o fechamento do equipamento de convivência Tenda Santa Cecília. Os conviventes aceitaram acolhimento na

112 Os agentes de saúde elaboram o Plano Individual de Tratamento (PIT). Somado ao PIA, ele constitui, segundo os técnicos do DBA, o "projeto de vida" do beneficiário. 
rede ou remanejamento para a Tenda Barra Funda, esta teve sua capacidade de atendimento ampliada de 300 para 450 pessoas por dia. Ou seja, antes de fechar a Tenda Santa Cecília promoveu-se o fortalecimento da Barra Funda para garantir a assistência ampla aos remanejados.

O Programa DBA foi idealizado e implementado no chamado curtíssimo prazo, menos de um ano após início do mandato do prefeito Haddad e permanecerá dentro do curto prazo até o término de seu primeiro mandato, ou seja, quatro anos. Observou-se em nossa pesquisa a busca por soluções individualizadas e nos termos colocados pouco acima, a cada período de seis meses, nova avaliação individual deverá ser feita para decidir pela continuidade ou desligamento de cada beneficiário do programa. Isto a depender de diversos fatores como: melhora nas suas condições de saúde física e mental, diplomação nos cursos e capacitações oferecidas com alocação em vaga de emprego, ou ainda outra forma de geração perene de renda.

A Operação Dor e Sofrimento, assim como o Programa Recomeço do governo estadual possuem a característica comum de buscar a retirada dos usuários de crack da região conhecida como Cracolândia. Esta retirada estava aparentemente ligada a um processo de busca da valorização imobiliária do bairro, materializada no projeto proposto pelo Consórcio Nova Luz junto à PMSP. O projeto chamado de Nova Luz (PREFEITURA DE SÃO PAULO, 2011), se interessava pela maior parte dos edifícios da região conhecida como Boca do Lixo e posteriormente por Cracolândia, nas suas diversas configurações geográficas assumidas no decorrer de duas décadas de existência, seria demolida em um processo semelhante aos descritos como casos de gentrificação. (NOBRE, 2013) A gentrificação costuma implicar em certo nivel de violência.

Confrontos entre policiais e usuários de crack ainda ocorrem em frente à sede do Programa DBA. Este programa surgiu 
com a retirada de 147 barracos e este fato marcou de modo indelével não apenas seu início, mas o limite do politicamente possivel e aceitável por parte da prefeitura. Um confronto entre a Tropa de Choque da Polícia Militar comandada pelo Governo do Estado e os usuários de crack - beneficiários e não beneficiários do Programa DBA - deu-se na manhã de 18 de setembro de 2014, em virtude do desmonte de barracos montados no "fluxo", em frente ao Programa DBA. Portanto, a baixa exigência do Programa DBA encontra um limite político: a remontagem dos barracos. Eles não eram um problema de saúde, tão pouco de segurança pública, mas eram um objeto de exploração midiática. Ao surgirem os barracos, na segunda metade do ano de 2013, a mídia explorou o fato à exaustão. Uma matéria publicada por Yarak \& Monteiro (2014) no jornal Folha de São Paulo é um exemplo deste tipo de cobertura midiática. Nela, os moradores dos barracos declaram ter de pagar $\mathrm{R} \$ 30,00$ para usá-los.

Porém, para o usuário de crack, o barraco é um local seguro e confortável para o uso da droga e também para seu comércio. O barraco proporciona a intimidade negada pela situação de rua e abriga contra o frio da noite e o sol. Não faltam vagas no Programa DBA, mais 150 novas vagas foram abertas, além das 422 existentes e a prefeitura espera vê-las preenchidas em breve. Do ponto de vista da administração municipal, o barraco é local propício ao tráfico e objeto de exploração midiática/política. Ele ficava fora do campo de visão das câmeras do micro-ônibus de vigilância, que depois viria ser retirado, fornecido pelo governo federal através do Programa Crack, é possivel vencer. O barraco é um ponto cego e a não construção de novas unidades havia sido pactuada no início do programa em reuniões do prefeito com representantes dos frequentadores e moradores da Cracolândia.

Apenas os desconhecedores da dinâmica do uso do crack podem defender a ideia de salas de uso para o craqueiro. $\mathrm{O}$ 
crack não é uma droga cujo consumo é separado por períodos de várias horas como a heroína, portanto, as salas de uso foram criadas para o consumo desta droga. Neste caso, o da heroína, se faz necessário um local limpo para aplicação com seringa e agulha hipodérmica, além do usuário retornar somente após algumas horas para novo uso. Nada mais diferente do crack, usado a intervalos de 15 minutos em média e tendo no cachimbo um meio seguro de utilização da droga quando não compartilhado. O usuário não "dá um "trago" e se retira do local, mas lá permanece interagindo animadamente com os outros na roda de crack. O "fluxo" em frente ao Programa DBA é um local ideal de uso, basta acrescentar-lhe alguns poucos mobiliários urbanos como os já instalados pela PMSP, bancos e floreiras. Além disto, poderiam se acrescentar toldos para os usuários se defenderem do sol. Alguns técnicos da prefeitura também cogitam lá instalar bebedouros e um espaço aberto para enfermaria.

Mudanças importantes trarão algumas correções de rumo significativas no Programa. A primeira delas foi a licitação para contratação de nova entidade responsável pela gestão dos contratos com hotéis e do POT, a Adesaf, no lugar da ONG Brasil Gigante contratada em caráter emergencial. Uma maior fiscalização da ocupação dos hotéis foi prometida pelo prefeito (PREFEITURA DE SÃO PAULO, 2014), isto levou a um controle maior da entrada e saída de pessoas, assim como a separação das famílias com crianças dos demais beneficiários. A descentralização e replicação com adaptações do programa foram iniciadas nas regiões de Vila Mariana, Lapa, Santo Amaro, Santana e Cidade Tiradentes. (PREFEITURA DE SÃO PAULO, 2014b) Algumas portas de saída se vislumbram pelo caminho do trabalho, como a contratação de 16 beneficiários por uma prestadora de serviços da prefeitura e a também contratação de 18 beneficiários em frentes de trabalho municipais, além dos 12 já trabalhando fora 
do POT. No serviço de varrição, ou zeladoria do bairro, são 228 beneficiários e 66 estão na Fábrica Verde, ${ }^{113}$ montada no Complexo Prates, um importante equipamento destinado à população em situação de rua. (PREFEITURA DE SÃO PAULO, 2014b)

Ao assumir a prefeitura em 2013, Fernando Haddad abandonou o Nova Luz e em prazo curtíssimo deu início ao Programa DBA, dotando-o da importante característica de se contrapor a tendência gentrificadora anterior. Teria como objetivo a busca, senão da integração cada vez maior dos usuários de crack na região, ao menos de sua manutenção no local, até cada caso individual encontrar seu desfecho. O Grupo Executivo Municipal (GEM), responsável pela concepção e implantação do programa esteve sob a responsabilidade da área técnica de saúde mental, álcool e drogas da SMS, coordenada pela profissional da saúde, dra. Myres Cavalcanti, uma grande crítica das internações em comunidades terapêuticas (BERGAMIN JUNIOR, 2013), como faz o Programa Recomeço. Isso mostra a diferença entre os programas estadual e municipal. Ao contrário de um propósito de retirada dos usuários do espaço por eles ocupado no bairro da Luz, deu-se sua acomodação em hotéis contíguos ao "fluxo" e com total liberdade de movimentação, inclusive para adquirir e usar drogas, tanto no "fluxo" como no interior dos quartos, sem a ameaça de desvincular quem quer que seja do programa, isto o diferencia das iniciativas anteriores. O Programa DBA pode ser encarado como uma ampliação de possibilidades dos usuários de crack, agora liberados da necessidade de permanecerem perenemente no "fluxo", com todas as dificuldades quanto à alimentação, sono, segurança e abrigo ligados a esta situação.

113 A Fábrica Verde fornece cursos profissionalizantes na área da jardinagem, paisagismo e permacultura urbana . 


\section{Lucas, o prefeito e um programa voltado do trabalho}

"A droga tem o espirito andarilho"114

As privações próprias da vida como consumidora de crack nas ruas da maior cidade do país são descritas por Esmeralda Ortiz - uma ex-menina de rua, autora do livro Porque não dancei - em detalhes aparentemente insignificantes do cotidiano, mas capazes de atingir uma importância imensa ao materializarem-se como carências. Coisas visivelmente simples como de água quente ou uma mesa para apoiar o alimento. A vida passada na rua é marcada pela falta e tem por companhia o risco da loucura, da morte e da prisão. Sair da rua para hotéis e ter acesso à alimentação garantida, quente e diária, chuveiro e cama, só não é uma grande mudança, se for percebida do ponto de vista daquele já acostumado com essas comodidades. Esmeralda nos dá um pouco da dimensão desta carência:

Como é gostoso um chuveiro. O chuveiro vai limpando a gente por dentro e por fora. Nunca tive um chuveiro. Nunca tive uma cama e uma casa de verdade. Agora, sim, tenho o meu chuveiro, tenho a minha cama, tenho a minha casa.

O prazer do chuveiro vem à minha cabeça hoje, 14 de março, uma terça feira, ano 2000. São dez horas. Faz muito sol. Os meninos estão se divertindo no chafariz da Praça da Sé. Dos 8 aos 15 anos, eu também pulava nessas águas e o chafariz era a minha felicidade. Mas o tempo passou. Hoje estou com 21 anos e não tomo mais banho na praça. Isso é coisa do passado. Agora, felicidade mesmo é estar na minha cama pra dormir.

114 Lucas - beneficiário do Programa DBA. 
Chegar em casa, não precisar mais de ninguém pra ficar abrindo e trancando a porta pra mim. Como isso é bom. É uma felicidade poder tomar um banho. Banho de chuveiro antigamente era só de vez em quando e gelado. Hoje tomo banho na minha casa e almoço e janto na mesa.

Nesse tempo, dos banhos gelados da Sé aos banhos do meu chuveiro quente, quase dancei, quase morri. Fui até o fundo. Roubei, fumei crack, fumei muito crack, trafiquei, fui presa, apanhei pra caramba. Diziam que eu não tinha jeito, estava perdida. Eu mesma achava que não tinha jeito. Quase todos os meus amigos daquela época do chafariz estão mortos, presos, loucos ou doentes. Gente que andava comigo, fumava comigo ou roubava comigo. Por que não morri? Por que não pirei? (ORTIZ, 2001, p. 20)

Do banho frio para o quente, da alimentação sobre o chão para a mesa e do fim trágico quase certo para a vida, Esmeralda nos dá um pouco da dimensão da transformação vivenciada a partir das mudanças das condições materiais de existência. Assim sendo, iremos abaixo analisar uma entrevista gravada com um beneficiário do Programa DBA para podermos verificar em seu discurso, quanto as modificações promovidas em termos de alimentação, trabalho, educação, lazer e acomodação puderam prover a base para um cotidiano diferenciado do vivido anteriormente.

Minha experiência no campo revelou-me a importância da interlocução na pesquisa etnográfica, entendida como troca. Troca de conhecimento e experiências, assim, minha vivência pregressa como usuário pesado de drogas revelou-se uma importante porta de entrada em assuntos possivelmente dificeis de tratar com "caretas". No campo, rapidamente me pareceu claro que para ser justo com os usuários de crack em minha reivindicação de que se abrissem e revelassem seus hábitos socialmente desqualificantes, seria necessário que eu também 
revelasse os meus. ${ }^{115,116}$ Ser usuário de crack, não implica ser desmedido ou descontrolado em seu uso, tão pouco nos demais consumos prazerosos, como o do alimento.

Lucas - Eu como só um pouco para me alimentar. Eu não tenho vício de comer. Tem pessoas que se você botar dez pratos, ele come os dez pratos.

Ygor $-E$.

Lucas - Tem pessoas que tem vício até pra comer. Aquele olho gordo. Eu não entendo. Fica atrás desse negócio dia e noite.

Para este beneficiário, vamos aqui chamá-lo de Lucas, o exagero é, primeiramente, algo a ser evitado em suas diversas manifestações e não apenas no uso da cocaína e do crack. Segundo, ele caminha em conjunto no indivíduo. Imódico em

115 Nesta entrevista, iremos perceber o quanto os usuários de crack valorizam a temperança e como o Programa DBA pôde contribuir em proporcionar o contexto favorável a um maior controle sobre o uso do crack.

Ygor - O Programa DBA vem servindo para alguns pelo menos, né? Não sei se pra todo mundo, né?

Lucas - Pra todo mundo não, porque muitos não têm mais noção, né? A droga, ela retarda um pouco o cérebro, né?

Ygor - Sei. Eu usei muita droga também, eu cheirava muita farinha. Fui até internado em clinica. Você foi internado já? Eu fui. Passei 31 dias. Sabe o réveillon do ano 2000, eu estava internado. Ai, eu saí. Mas dai, eu parei. Agora, ano passado que eu fumei umas pedras pra entender como é que era, entendeu? Fumei na Rua São Paulo, não sei se você conhece lá?

Lucas - Não. Tem gente que não tem a visão das coisas. Porque tem pessoas que viciam nesses negócios. Tem pessoas que não viciam.

Ygor - É.

Lucas - Eu mesmo, sou uma pessoa que não tenho vício nenhum.

Ygor - Você é lá de Osasco, né?

Lucas - É, morei 16 anos em Osasco. Tenho um ano aqui, agora. Eu sou da Bahia, então, eu vim para aqui em 1989, 20 anos aqui.

Ygor - 25 anos.

Lucas - É, eu vim pra cá, no ano 2000, em 1998.

116 Nesta entrevista, iremos perceber o quanto os usuários de crack valorizam a temperança e como o DBA pôde contribuir em proporcionar o contexto favorável a um maior controle sobre o uso do crack. 
um aspecto, descomedido em outro, mesmo no sono, como veremos à frente, ou até no caminhar. A temperança pode ser aqui entendida em seu sentido aristotélico como justo uso dos prazeres físicos. (ARISTÓTELES, 1973)

Ygor - Você veio em 1998 pra São Paulo?

Lucas - É essa fase aí. Então, eu já fui traficante, já fiz de tudo. Já usei droga, já roubei, já fiz de tudo. Eu nunca vicio em nada. Não sou viciado nem em comer, eu sou.

Ygor - Risos

Ygor - Fica dia e noite no 'fluxo', né?

Lucas - É dia e noite usando esse negócio, eu não. Difícil usar. Se quiser usar hoje eu uso, se não quiser não uso. Pode ter mil usando aí.

Ygor - É. Porque tá ali do lado, é só atravessar a rua.

Lucas - Então, eu sou uma pessoa desse jeito, mas a maioria das pessoas não são assim.

Nosso interlocutor não se considera um usuário problemático por não se deixar levar pelos outros, pelo "fluxo". Para ele, os demais usuários da Cracolândia podem fumar crack e mesmo assim, ele não será afetado. Como não é viciado sequer em comer, não se vicia nos demais prazeres aristotélicos sujeitos a intemperança, ou seja, os prazeres derivados da alimentação e da bebida. ${ }^{117}$ A droga lá se encontra disponível, porém, um ex-traficante como ele, possivelmente devido aos compromissos e responsabilidades próprias dessa atividade comercial ilícita, aprendeu a ter autocontrole sobre seu uso. (GRUND, 1993) Esse controle pode advir também das atividades e compromissos assumidos ao tornar-se beneficiário do Programa DBA.

Ygor - Eu mesmo não sabia usar não. Exagerava.

Lucas - É? Porque aí, você quer todo dia, todo dia. Muitas pessoas não pega, não. É tipo o projeto. Muitas pessoas estão firmes, trabalhando, fazendo curso.

117 Aristóteles também acrescenta os prazeres do sexo à sua lista. 
Ygor - Mas, começou o curso já?

Lucas - Já. Começou o curso de jardinagem, começou o curso já, no Tatuapé. Começou o curso aqui, na Porto Seguro ${ }^{118}$. Vai começar o curso aqui na Barra Funda, no Boraceia. ${ }^{119}$ Aquilo lá é tudo curso. Eu mesmo fechei um curso lá, um curso de zelador.

Ygor - Você vai fazer?

Lucas - O curso de zelador. Já sai empregado, já.

Os beneficiários comprometidos, dedicados, integrados ao projeto, como Lucas se refere ao Programa DBA, seriam aqueles que deixariam de "querer todo dia". O desejo pode ser controlado, modificado; até desviado para um projeto de futuro possivel, em consonância com as condições ditas estruturais, econômicas, correspondentes a um mercado de trabalho ávido por absorver mão de obra plenamente empregável. O Programa DBA, com seus cursos, trabalho e horários incentiva, assim como fez a experiência de traficante, o cumprimento de horários e compromissos. O emprego no tráfico pode, em uma conjuntura de plena empregabilidade, ser substituído pela ocupação de zelador para quem for capaz e interessado em "pegar firme".

Ygor - Já, né? É porque tá faltando. Tá faltando gente pra trabalhar. O salário inicial, sabe qual que é?

Lucas - Inicial? Não, não sei.

Ygor - Deve ser mil e pouco, né?

Lucas - É. Os salários não são tão ruins. Tá faltando é o trabalhador. Muitas pessoas não querem, outras não tem documento. Outros não têm endereço, outros não têm moradia, então tá essa demanda. Esse baila, baila, aqui em São Paulo é essa a situação.

Ygor - E vocês aqui, conseguem dar o endereço do hotel?

118 A empresa Porto Seguro possui vários prédios de escritórios na região e ofereceu alguns cursos de formação dentro das dependências da empresa.

119 Boraceia é o nome de um antigo equipamento de manutenção de veículos da PMSP transformado em Tenda e Centro de Acolhida. 
Lucas - Consegue. Dá. A ONG dá. A ONG dá a declaração de endereço.

Ygor $-A h$...

Lucas - O escritório, né? O escritório dá o endereço do hotel.

Ygor - O escritório dá o endereço do hotel como do beneficiário.

Lucas - É, o do hotel.

Ygor - Então, o cara não está mais sem endereço. O da rua.

Lucas - Não. Ele tá num endereço fixo

Ygor - Isso.

Lucas - Porque ele tá morando naquele hotel.

Ygor - Entendi.

Os beneficiários são acomodados ou alojados como hóspedes nos hotéis do entorno da Cracolândia, nas mesmas ruas que outrora eram exclusivas do "corre", da "treta", da repressão policial, da Operação Dor e Sofrimento e do uso. Agora, eles têm a oportunidade de possuir um endereço fixo para recebimento de correspondência e, principalmente, para fornecerem aos futuros empregadores. O hotel, além de acolhida para o sono reparador, é local onde agentes comunitários de saúde e agentes socioeducativos realizam a busca ativa aos beneficiários que possam se encontrar em dificuldade para participar devidamente do trabalho de zeladoria, seja devido a problemas de saúde física ou mental, seja por outro motivo qualquer. Nele também pode se dar a oferta de serviços variados como a retirada de documentos, por exemplo. A documentação, o domicílio, os cuidados com a saúde, cursos e indicações para vagas abundantes de trabalho com salários razoáveis, em consonância com as expectativas destes usuários de crack, vão compondo um arranjo estrutural que torna possível a adoção de uma visão de futuro e autocontrole do uso da droga. 
Lucas - Então, tudo é uma vantagem, porque o prefeito, ele tá querendo organizar as pessoas. As pessoas que tá com a mente ainda com visão. Certo? Pra fazer um curso, procurar trabalho. Você tá entendendo? Que tá um mês, dois, três meses no hotel. Depois alugar uma casa, um cômodo, uma coisa pra morar. Não vai poder ficar naquele hotel toda vida.

Ygor - Mas acho que dá pra ficar. Acho que é de seis em seis meses que a galera vai avaliando, né? Assim, se fica mais.

Lucas - Certo.

Ygor - Se já vai pro albergue. Porque às vezes, o cara também sai. Vai para um centro de acolhida, ou aluga uma casa e desanda também. Às vezes é bom ficar [...] não sei. Não sei como eles estão fazendo.

Lucas - Pra tudo tem que ter o primeiro passo, né? Tem que ter a primeira pisada. Pra tudo. O prefeito tá organizando isso aí. Aqui no centro de São Paulo, é muita gente nessa situação.

Ygor - É...

Ygor - Mas a galera que te acompanha no trecho, que você conhece daqui. Mudou alguma coisa na vida de alguns deles assim, melhorou?

Lucas - Muitos melhoraram, assim, porque diminuiram de usar. Muitos não tinham documento, tá tirando. Muitos tá fazendo curso [sic], então, tá tendo um pouco de visão, né?

Ygor - Sei. E porque que diminuiu de usar?

Lucas - Porque ocupou o tempo e já tem já um lugar pra dormir. Já tem um lugar pra comer. Já entra mais uma visão pra ele.

Ygor - Tem atividade de manhã, de zeladoria.

Lucas - Tá entendendo? Tem o curso, tem tudo, então, tudo ocupa o tempo. Certo? Não tem nem tempo pra sair pra roubar.

As visitas periódicas do prefeito Fernando Haddad à Cracolândia deixam marcas profundas nas expectativas dos beneficiários. A impressão transmitida, de um cuidado pessoal por parte da maior autoridade municipal com o Programa DBA provoca neste beneficiário, a abertura de sua percepção para novas 
possibilidades de vida, uma nova cotidianidade normatizada, marcada pelo retorno a si, pelo autocuidado, pela retirada da incerteza das consequências (VARGAS, 2006), pelo previsível. $\mathrm{O}$ autocontrole vivido na diminuição do uso encontra-se atrelado, na fala deste interlocutor, à qualidade do fruir do tempo no cotidiano. Dormir, comer, trabalhar e estudar ocupam os momentos antes reservados à fruição da pedra e do "corre", às vezes materializado nos pequenos furtos.

Ygor - Risos. O cara até pensa duas vezes. Porque a vida dele às vezes nem tá tão ruim assim. Vai, pô. Vai arriscar isso aqui, vai parar numa cadeia aí, tal.

Lucas - É, aí, num dá certo. Muitos vai [sic] uma vez, a policia pega, dá um tapa. E fala 'da segunda vez'. Ai vai 'aquela pressão'. Então, intimida mais a pessoa. Então, vai mudando. Muitos que tem a visão aí, vai mudando. Pra muitos que a mente tá 'meia fraca', aí, num entra fácil. Você tá entendendo? É essa a situação. Aí, relaxa, fica sem comida, de noite não dorme. O pessoal que dormiu à noite, de dia não vai dormir, não vai 'se largar' (apontando para um beneficiário uniformizado dormindo sob a tenda). Ygor - Deve ter passado a noite no 'fluxo' e agora, deu sono, né?

Lucas - Dá moleza. É, fica assim ó, deitado. Eu dormi a noite toda. Como é que eu vou dormir? Como é que eu vou dormir agora de dia?

Ygor - Você dormiu a noite?

Lucas - Dormi a noite toda. Deito cedo. Agora, tô sem sono. Me alimentei.

Deitar-se cedo e dormir bem é fruto de negociação e convivência proporcionadas pelo tempo vivido conjuntamente. O silêncio é negociado. Outro tipo de negociação se interpõe quando se deixa para trás a dinâmica do barraco para passar ao convívio no quarto coletivo de hotel. Certamente, passa-se a outro tipo de negociação, já que esta agora é mediada pelas equipes de agentes sociais, pela assistente social e pelas agentes socioeducativas. Em nossas visitas ao campo, observamos 
que é também mediatizada pela disciplina imposta e sempre negociada com as lideranças locais. Esta seria uma espécie de último recurso para casos mais relutantes.

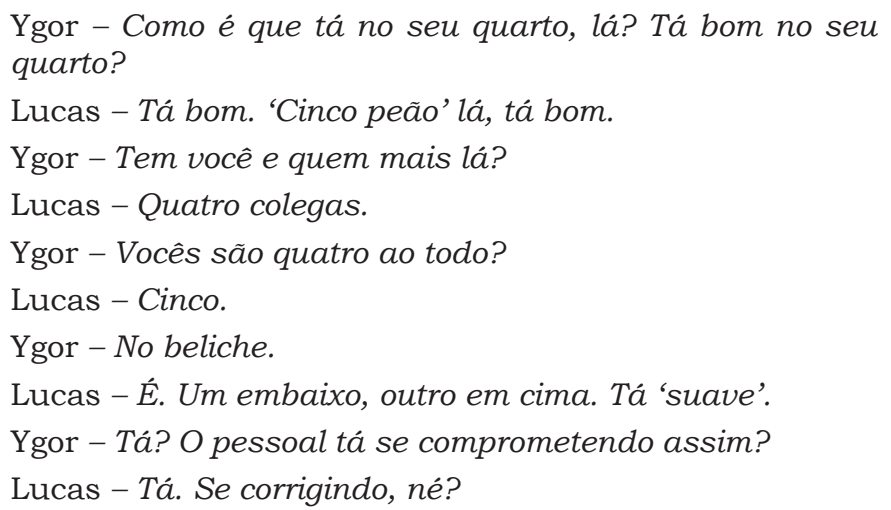
Nem todos se controlam. Vai da mente, do estado da pessoa.

Ygor - Mas ninguém atrapalha sua dormida lá? Você deita tal, fica em silêncio.

Lucas - Não. Sempre combina, né?

Lucas - Sempre se combina. Não tem jeito. Depois de um mês, dois meses dentro de um quarto, você combina.

Ygor - Ah, entendi.

Lucas - De boa. Tá tendo um controle bom.

Veremos no capítulo dedicado às oficinas e campeonatos de futebol como a mudança de um projeto de oficina de futebol para o treino dedicado a participação em campeonatos promoveu a alteração de situações sem autoridade central, sem juiz e contando apenas com algumas intervenções do professor, para uma nova condição em que ocorre a monopolização da organização das equipes pelo professor/técnico, assim como o monopólio das decisões quanto à interpretação das regras passa a ser concentrado no juiz. Observaremos, com Norbert Elias (2007), as potencialidades educativas dos monopólios de poder, no sentido de possibilitarem o autocontrole do indivíduo 
submetido a regras externas, ao promoverem a interiorização das proibições e o refreio de seus impulsos e movimentos imediatos. O controle exercido pela prefeitura sobre a ocupação dos quartos é dinamizado pelo controle exercido por um "peão", alcunha dada ao trabalhador operacional em São Paulo, sobre o outro "colega". Para acomodar cinco usuários de crack em um quarto, certamente se faz necessária a criação de uma gama de regras de convivência, ou seja, de controles informais (ZINBERG, 1984) a partir do diálogo e aferição de expectativas e demandas reciprocas. Da mesma forma que sucede em um alojamento de trabalhadores de uma obra da construção civil, estes "parças" metamorfoseados em "peões" pela adesão ao Programa DBA passam a conviver em uma dinâmica que aos poucos vai se diferenciando daquela vivenciada por eles durante anos nos barracos, ou mesmo nos Centros de Acolhida e Convivência. É necessário que desenvolvam uma capacidade de negociação do uso do espaço comum e permanente, diferenciada daquela do barraco, com sua plasticidade ${ }^{120}$ e mobilidade, possivel de ser desmontado em um momento para ser remontado em outro local próximo, desfeito e refeito ao sabor das desavenças. Esta capacidade de transação entre vontades, por parte daqueles geralmente acusados de a terem perdido para a droga, tem na convivência no quarto de hotel um importante meio de expressão e desenvolvimento. Esse vínculo desenvolvido entre os beneficiários é somado àquele estabelecido pela convivência com as equipes de agentes socioeducativos de Smads. Abaixo, reproduzimos um diálogo onde veremos como o beneficiário conhece a história de uma agente. Além disso, durante essa conversa conosco, outras agentes passaram ao nosso lado, sendo introduzidas em nosso diálogo. Nessa ocasião pudemos observar como ele detinha um conhecimento similar da vida pessoal destas outras pessoas e este fato, do beneficiário conhecer parte da história de agentes socioeducativas, nos

120 Literalmente, os barracos são cobertos por plástico preto. 
revela além de vínculo e empatia, o intercâmbio de histórias entre eles, semelhante ao procurado por nós no momento de nossa interlocução.

Lucas - Mas a prefeitura não quer que fique nessa. Põe nego pra fazer curso e já quer que coloque na 'firma'. Curso, agora, você já sai direto empregado. Sei que o prefeito tá gastando uma verba boa, 'forte'.

Ygor - São 429 já.

Lucas - É? Milhões?

Ygor - 429 beneficiários.

Lucas - A prefeitura tá gastando dinheiro grande, com funcionário, né?

(Neste momento, cumprimento uma orientadora socioeducativa de Smads)

Lucas - Ela paga aluguel, mora com a filha dela. Conversou comigo, já.

Ygor - Ah, você já conversou com ela?

Lucas - Dessa idade, 'rala'.

Ygor - Ela cria a filha dela.

Lucas - Ou filha, ou filho, não sei.

Ygor - E o trabalho delas aqui é cansativo.

Lucas - Ajuda muito. Dá encaminhamento.

Ygor - Isso.

Lucas - Tudo anotado. Trabalha bem. Uma profissão boa que a prefeitura inventou. Uma maneira de emprego e de pôr as pessoas pra ficar ajudando as pessoas. Menina bonita. Tudo educada.

Ygor - A maioria é estudante de serviço social.

Lucas - Tão estudando, aprendendo.

O caminho "projeto", "curso", "firma”, são concebidos pelo beneficiário como sendo lastreado por forte investimento público e pela determinação aparente da "prefeitura" em provocar o movimento. Este movimento, como visto anteriormente, no capítulo dedicado aos padrões de uso, é um valor entre os usuários de crack. O "parasita", aquele parado na "biqueira" à 
espera de oportunidade de obter um "trago" sem prestar-se ao movimento necessário do "corre" ou da "correria", tende a ser mal visto e mal afamado entre os demais usuários, assemelhando-se ao beneficiário incapaz de pegar "firme" no "projeto". Os valores dos usuários não seriam tão diferenciados dos valores do mundo do trabalho e servem como controles sociais informais para regular o uso. (ZINBERG, 1984) Não nos passa despercebido o fato de ter deles partido a reivindicação ao prefeito de trabalho para todos além de alojamento, quando das primeiras visitas de Haddad à Cracolândia. O crack possui um "espírito andarilho", o movimento dentro de si.

Ygor - Antes delas virem pra cá, eu dei um curso pra elas lá no Complexo Prates.

Ygor - Sobre droga, tal. Embora, a maioria delas conheçam lá do bairro delas. Para elas verem que quem usa crack não é transloucado.

Lucas - É só um assombro, fica assombrado.

Ygor - Risos. Quando tá muitos dias, aí começa a ficar meio ruinzinho.

Lucas - É, não tem alimentação.

Ygor - Mas o cara que é beneficiário, ele já usa, ele vai, janta, almoça.

Lucas - Toma um banho. Dorme. É vantagem. Muitos tá deitadão [sic] aqui. Já comeu, vai deitar. Uns toma banho, outros levanta mais tarde.

Ygor - Porque na rua, bem ou mal é ruim pra dormir. É frio né, cara?

Lucas - Tem que dormir no chão. E o frio? Não consegue dormir. Fica só andando. Compra um 'Corotinho' [...].

Ygor - E fica só andando, né? Não consegue dormir.

Lucas - É. Uns colegas vêm, dá um 'trago' de droga, já começa a andar. Quem usa droga não para, fica andando.

Ygor - Fica andando, né?

Lucas - A droga tem o espirito andarilho, né?

Ygor - (Risos)

Lucas - Tem uma hora que eu estou aqui sentado. Se estivesse usando droga, eu não estava aqui. 
Ygor - Não dá, né? Não dá nem pra ver uma televisão, né? (Olhando para o aparelho de TV da tenda). Não tem paciência.

Lucas - Tem pessoas que não conseguem dormir, eu mesmo não consigo dormir.

Ygor - Eu não consigo. De jeito nenhum.

Lucas - Se eu usar droga me baixa um espirito. Eu fico espantado. Eu tenho medo de mim mesmo.

Ygor - A gente falava assim. Fica 'fritando'. 'Fritando' na cama. Você não dorme.

Lucas -É... É verdade. É a vida... Na vida tem de tudo, né?

A cachaça Corote, ${ }^{121}$ a qual se refere Lucas, é extremamente popular entre a população de rua da cidade de São Paulo e, particularmente, entre os usuários de crack da região central, tornando-se termo genérico para pinga ou cachaça. Existem outras marcas com o mesmo volume e preço, cerca de $\mathrm{R} \$ 2,00$ por $500 \mathrm{ml}$ de produto.

William Burroughs (2013) nos traz uma infinidade de importantes ensinamentos sobre o uso de drogas ao relatar a própria experiência como junkie nos Estados Unidos da metade do século XX. Esse autor nos dá verdadeiras lições, muitas apropriadas a analogias com o uso do crack no Brasil do século XXI, malgrado a distância geográfica e temporal entre as duas realidades e a necessidade de se promover as devidas mediações. Ele nos relata, por exemplo, o prazer do uso da droga que estaria intimamente ligado às condições de uso, entendidas como a rotina do usuário, seu acordar e sair à procura da próxima dose, a fissura e o prazer de livrar-se dela, enfim, viver sujeito ao "clima junk", no qual: "O barato junky é ter de viver sob condições junkies”. (BURROUGHS, 2013) O Programa DBA mudou as condições e o barato daí proveniente. Deixar de ser, na prática, população de rua e craqueiro, para tornar-se um

121 <http: / / circuito10.blogspot.com.br/2013/08/calouro-entra-em-coma-apos-ser-obrigado.html>. 
beneficiário, embora ainda mantendo um uso de crack, significa uma grande mudança de condição.

\section{O Programa De Braços Abertos como oportunidade de mudança} na estrutura de vida

Discutiremos agora, um pouco mais detidamente o trabalho de Grund (1993) sobre usuários de drogas de Roterdã, para em seguida tirarmos nossas conclusões a partir de seu modelo. Muitas teorias enfatizam as poderosas propriedades farmacológicas dos psicoativos, outras, destacam estruturas de personalidade deficientes. É também comum associar o uso de drogas a deficiências de desenvolvimento social, como pobreza. Para Grund, não se deve colocar ênfase em um dos aspectos do uso de qualquer droga, seja ele farmacológico, psicológico ou o social. Enquanto a maior parte das teorias sobre o uso de substâncias é baseada em experiências advindas da clínica de usuários problemáticos, para o autor, se queremos chegar ao fulcro da questão, torna-se necessário estudar o fenômeno primordialmente em sua arena natural. Assim, deveria-se observar cuidadosamente, através de uma pesquisa etnográfica, indivíduos em seu dia a dia, registrando quando fazem, o que fazem, onde, com quem e por quê, evitando as cegueiras das noções pré-concebidas. Para tanto, Grund em sua pesquisa sobre usuários de cocaína e heroína teve de adentrar na comunidade sob estudo, muito similarmente ao antropólogo cultural clássico que estuda uma sociedade tradicional. Sua análise resultante fundamentou-se nesse estudo da experiência e percepção dos sujeitos sobre seu contexto.

O material foi colhido de um estudo etnográfico de usuários regulares de heroína e cocaína em Roterdã, nos Países Baixos. Largamente baseado na observação participante, o estudo de Grund (1993) descreve padrões de uso, suas funções, significados e determinantes. O maior objetivo da sua pesquisa foi descobrir as funções e significados do comportamento ritualizado 
relacionado a drogas. O achado mais importante é que estes comportamentos fornecem uma infraestrutura para o processo de autorregulação controlador do uso.

Uma característica proeminente dos rituais e regras é que elas visam controlar ou regular a experiência de uso da droga, assim, os dados da pesquisa de Grund (1993) fornecem forte apoio à teoria de Zinberg (1984), vista anteriormente. Este considera que o uso de drogas é amplamente regulado por controles sociais - rituais e regras (ou "sanções sociais" como Zinberg as chamou) que moldam a maneira como a droga é utilizada. Através de processos de aprendizagem social com seus pares, rituais específicos e regras são desenvolvidos como adaptações para os efeitos das interações entre droga, personalidade e ambiente.

Contudo, a habilidade para autorregular o uso da droga não se encontra igualmente disseminada por todos os usuários, assim sendo, alguns usuários nos estudos de Grund (1993) pareciam ser capazes de usar grandes quantidades de heroína e cocaína apresentando poucos dos problemas característicos, enquanto outros - tipicamente os usuários marginalizados ao redor da Estação Central de Roterdã - apesar de acabarem por usar menos das substâncias (que para eles eram caras e de baixo grau de pureza), pareciam mais suscetiveis aos problemas relacionados. Assim, autorregulação ou controle implicam em mais do que simplesmente limitar o consumo, devendo-se também levar em conta a prevenção dos problemas relacionados a este consumo na vida cotidiana. Para Grund (1993), a teoria de Zinberg não explica adequadamente as variações entre os usuários, encontrados no estudo de Roterdã, em relação à sua resposta aos diferentes controles sociais vigentes. Considera que a teoria de Zinberg seria estática por não tratar de outros fatores que tem impacto sobre a eficácia de rituais e regras. Portanto, a eficácia de regras e rituais seria aparentemente moderada por fatores adicionais não trabalhados por Zinberg. 
Grund sugere então que, além dos controles sociais informais discutidos por Zinberg, deve-se também levar em conta a disponibilidade da droga e a estrutura de vida dos usuários. $\mathrm{O}$ estudo de Grund irá tratar da interação entre disponibilidade da droga, rituais e regras e estrutura de vida, para tentar especificar e detalhar o contexto social no qual os processos auto regulatórios se plasmam. (GRUND, 1993, p. 236)

Para tanto, foi apresentada uma análise secundária dos dados de admissão referentes ao ano de 1989, no tratamento dos programas de metadona de Roterdã (RODIS). Este relatório contém dados sobre uso de cocaína e etnicidade; prevalência na vida de overdoses, episódios psicóticos, inconsciência e convulsões. Também traz dados sobre o nivel de uso de heroína e suas associações mútuas. A prevalência de problemas em usuários de cocaina foi também analisada para determinar diferenças entre grupos étnicos: holandeses, surinameses / antilhanos, marroquinos e estrangeiros. O grupo surinamês/ antilhano apresentou o mais baixo de todos os indicadores, enquanto o holandês teve as maiores marcas.

Entre os usuários holandeses de heroína, 55\% usavam cocaína sem problemas e $9 \%$ consideravam o seu uso como problemático. Entre os surinameses/antilhanos a prevalência do uso de cocaina era maior $77 \%$, mas aparentemente isto levava a menos problemas 3\%. O uso da heroína foi correlacionado positivamente com o uso da cocaina, a heroína era empregada para controlar os efeitos colaterais da cocaína. O estudo de Grund (1993) apontou o fato de os usuários surinameses usarem mais frequentemente cocaína, mas experimentarem menos problemas com o uso desta droga.

Os usuários envolvidos com sucesso no tráfico estão em uma posição melhor para exercer controle sobre seu uso de drogas, sofrem menos dos problemas relacionados à cocaína e dependem menos do ritual: heroína controla cocaína. Como vimos acima, era comum, entre usuários de cocaína estudados, o uso da 
heroína para contrabalançar os efeitos estimulantes da cocaína. Os surinameses dominavam a distribuição no varejo, ocupando posições chave em grupos multiétnicos e tinham os melhores contatos com fornecedores de nível médio, uma vez que estas posições eram frequentemente também ocupadas por surinameses.

A manutenção dos altos níveis de uso, típicos da população deste estudo, requer uma disponibilidade de drogas suficiente e fundos para financiar a compra. Em decorrência disto, a renda legal é normalmente insuficiente para cobrir altos niveis de uso de drogas, portanto, geralmente os recursos necessários só podem ser obtidos através da prostituição ou atividades ilegais, tais como crimes de aquisição ou vendendo drogas. No contexto holandês, o expediente mais lucrativo é o tráfico varejista. Transações de drogas no nivel do consumo são toleradas até um alto grau e em contraste, o roubo tornou-se mais dificil ano após ano com a população usuária de drogas envelhecendo. Em longo prazo, as carreiras criminais tornam-se demasiadamente exigentes por seus componentes de risco.

Fatores semelhantes podem influenciar o ganho de usuários envolvidos no trabalho sexual. O número de clientes e o preço do atendimento sexual podem variar com flutuações diárias no tempo, sinais de crise de abstinência, infecções genitais, períodos de gravidez, festas de Natal e jogos de futebol. Também desempenha um papel importante, a deterioração da aparência do indivíduo devido à má administração do uso de drogas e estilo de vida adotado. O sucesso no crime e na prostituição é, assim, acessivel a apenas uma minoria de usuários. Dadas as condições holandesas, usuários bem-sucedidos - em termos de serem capazes de consumir alta quantidade de drogas sem experimentar os problemas associados - estarão provavelmente envolvidos no pequeno tráfico.

Grund (1993) argumenta que, no caso holandês, embora limitar artificialmente a oferta de drogas possa deter o seu consumo até certo ponto, isto teria um considerável custo psicos- 
social. Além de criar um incentivo econômico forte para a venda de drogas em circuitos empresariais desregulados, restringir a disponibilidade induz e alimenta um processo psicossocial que multiplica muito o valor ritual das drogas - inaugurando um estreitamento do foco do usuário. Fixação na droga irá levar a uma forte limitação das expressões comportamentais quando a droga é ansiada e dificil de obter, e ao consumo exagerado e impulsivo quando uma dose se torna disponível. Como resultado, rituais e regras ao redor da droga se tornam menos dirigidos à autorregulação e segurança no sentido da saúde, porém, mais no da proteção, sigilo e facilitação do uso de drogas e atividades correlatas (por exemplo, transações com drogas). Em contraste, a ausência de incerteza quanto à obtenção da próxima dose libera o usuário das preocupações obsessivas correntes com (obter) as drogas e a necessidade de batalhar por ela. Suficiente disponibilidade ainda cria uma situação propícia ao desenvolvimento de rituais e regras que restrinjam o uso da droga e induzam padrões de uso estáveis. Como os resultados mostram, isto não necessariamente significa níveis menores de uso de drogas. Quando a droga é suficientemente disponivel os usuários estudados podem, aparentemente, sustentar altos níveis de consumo sem desenvolver problemas típicos relacionados a drogas. Uma disponibilidade suficiente pode assim ser entendida, no caso holandês, como precondição para o desenvolvimento e efetividade de rituais e regras que regulem os padrões e niveis de uso.

Além da disponibilidade da droga, a estrutura de vida é composta por um importante conjunto de variáveis que guiaram o estudo de Grund e se referem a padrões regulares de atividades laborais, recreativos, domésticos e criminais que moldam e constrangem o dia a dia de usuários de heroína. Faupel (1987) foi um dos autores fundamentais no estudo de Grund, ele enfatizou a importância das atividades regulares (tanto convencionais quanto as relacionadas ao uso de drogas) que estruturam os padrões diários como chaves da estrutura 
de vida. Parece lógico, para Grund, incluir os relacionamentos pessoais, compromissos, obrigações, responsabilidades, metas e expectativas que são exigentes e, simultaneamente, têm valor social (afetos) ou econômico (salários) como determinantes igualmente importantes para a estrutura de vida. Contatos regulares com usuários controlados e não usuários são também de considerável importância, lembremos o quanto Zinberg salientou este aspecto. Assim como, são importantes para Grund a participação nas estruturas e atividades não motivadas primariamente por incentivos relacionados a drogas.

Apesar da disponibilidade da droga ser essencial para o desenvolvimento de controles sociais, sem uma estrutura de vida estável, apenas the oferece apoio limitado. A importância da estrutura de vida é muito claramente demonstrada pela sua ausência, como representado pelo junkie de expedientes apresentado na tipologia de uso de heroina de Faupel (1987).

Quadro 2 - Tipologia para o uso de heroína de Faupel

\begin{tabular}{|c|c|c|}
\hline Disponibilidade de drogas & \multicolumn{2}{|c|}{ Estrutura de vida } \\
\hline & Alta & Baixa \\
\hline Alta & Junkie estabilizado & Junkie de expedientes \\
\hline Baixa & Usuário ocasional & Junkie de rua \\
\hline
\end{tabular}

Fonte: Adaptado de Faupel (1987).

Apesar de ter amplo acesso a drogas, o junkie estabilizado consegue controlar seu uso ao contrário do Junkie de expedientes que possui baixa estrutura de vida e dedica-se, em parte de seu tempo, a práticas de obtenção de fundos para aquisição de substâncias. O usuário que possui alta estrutura de vida e baixo acesso às drogas tenderá a permanecer como um usuário ocasional, caso não haja nenhuma modificação substancial em nenhuma das variáveis que compõe sua estrutura de vida, ou um eventual aumento na disponibilidade. Por fim, o junkie 
de rua encontra-se na pior situação entre os tipos acima. Com frágeis conexões relacionadas a atividades fora do universo do uso de drogas e baixa disponibilidade, ele será empurrado para uma situação de alta vulnerabilidade com conexões cada vez mais frágeis com não usuários e vínculos progressivamente menores com atividades não pertinentes ao uso de drogas. Além disto, ele terá de dedicar grande parte de seu tempo à obtenção de fundos para o consumo de substâncias.

Em nossa observação participante do uso do crack na região central da cidade de São Paulo, pudemos ver a importância de todos os expedientes constantes na "treta" e no "corre" que possibilitam alguma disponibilidade de crack aos usuários. Isto os manteriam, se levarmos em conta o esquema de Faupel (1987), próximo ao tipo do junkie de expedientes. Porém, o alto custo da pedra e as exigências do corre, certamente, dificultam os rituais voltados à preservação da saúde, em favor de uma cultura voltada a constante obtenção de recursos a serem incorporados ao circuito da "treta", como visto neste livro. Discutiremos melhor o assunto mais à frente.

Um crescimento repentino na disponibilidade de drogas - um grande golpe - perturba ou desestabiliza o padrão diário e estabelecido de atividades (tanto convencionais como relacionado a drogas) e pode resultar em uma escalada nítida do uso. Quando as drogas e o dinheiro terminam, o usuário muito frequentemente se encontra em uma posição pior - habituado a um nível de consumo mais alto, enquanto que as conexões necessárias para uma geração de renda constante foram negligenciadas.

No final de cada dia, o junkie estabilizado como pequeno traficante deve ter ganhado dinheiro para pagar seu estoque para o próximo período. Um traficante bem-sucedido trabalha sempre em horas fixas, com um time razoável de empregados e mantém um registro preciso do balanço financeiro. Ele não pode, por exemplo, aparecer no ponto de venda em horas irregulares. Esse comércio varejista para ter sucesso requer esta- 
bilidade e continuidade. Tais estipulações estruturam substancialmente a alocação de tempo dos traficantes exitosos.

Assim, manter uma estrutura de vida estável em alto grau - requer cuidadosa administração do consumo de drogas e de atividades correlatas e depende do desenvolvimento e do cumprimento de certas regras. Controlar o seu uso de drogas durante o horário de trabalho é um pré-requisito para uma participação produtiva no tráfico. Surinameses pesquisados por Grund frequentemente exercem intensa pressão social um sobre o outro para que permaneçam em controle. Até certo ponto, o controle também é exercitado por parceiros não usuários e pela família. A repressão formal relativamente pequena que sofrem os usuários de heroína nos Países Baixos tem sido um facilitador indispensável dos processos de aprendizado social que promovem o uso controlado de drogas.

O nivel mais alto de autocontrole encontrado entre traficantes pode agora ser explicado como um exemplo de interação entre a disponibilidade da droga, rituais e regras e estrutura de vida. O tráfico exige certo grau de estrutura de vida na alocação de tempo, nos relacionamentos com clientes, comparsas e fornecedores atacadistas, estimula conexões exigentes, compromissos, obrigações, responsabilidades e expectativas. A disponibilidade é uma pré-condição para o desenvolvimento e manutenção de rituais e regras reguladores. Disponibilidade da droga, rituais e regras e estrutura de vida são uma tríade - fatores interativos em um processo circular coerente internamente no qual estes fatores são eles mesmos modulados (modificados, corrigidos, reforçados, etc.) por seus resultados. É, portanto, um circuito de retroalimentação que determina a força de processos de autorregulação controlando o uso da droga. O quadro do Modelo Retroalimentativo esquematiza este circuito. (GRUND, 1993, p. 248) 
Figura 41 - Modelo retroalimentativo da autorregulação do uso de drogas de Grund

\section{Modelo retroalimentativo da autorregulação do uso de drogas de Grund - A tríade DDRREV na Cena de Uso}

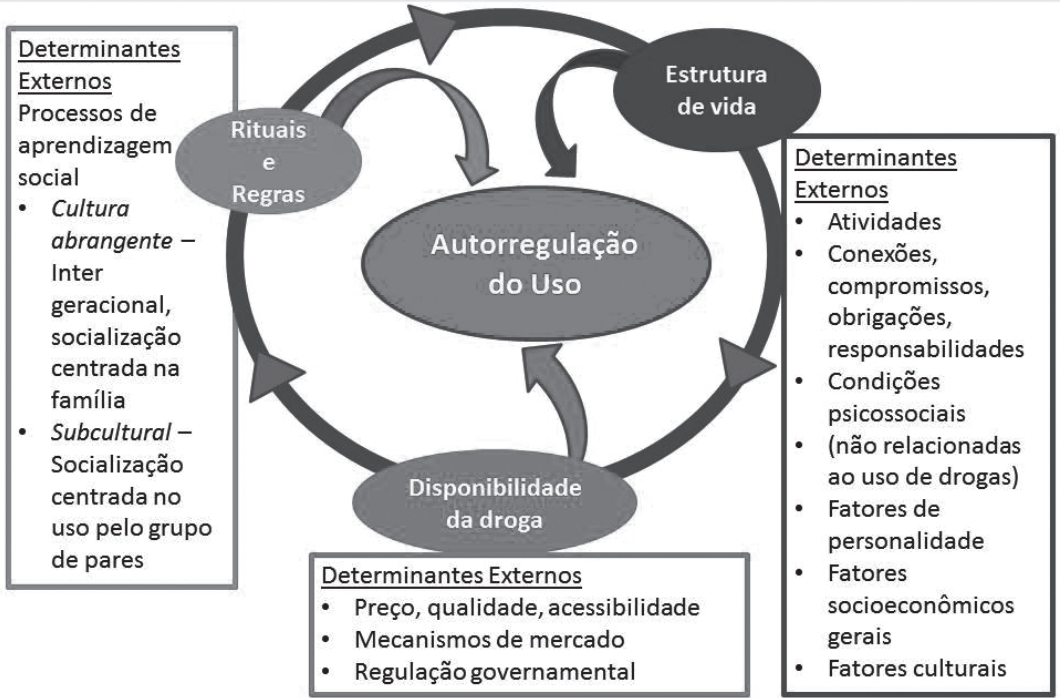

Fonte: Adaptado de Grund (1993).

O desafio não enfrentado pela internação compulsória e pelo Programa Recomeço do governo estadual é o de estruturar a vida em um contexto pós-Cracolândia. Já no Programa DBA, a estrutura de vida é construída no processo de adesão e permanência no programa. A disponibilidade da droga, fundamental para a edificação de alternativas de vida cotidiana não centrada em rituais e regras dedicados à sua aquisição é garantida pelo tráfico a varejo existente no "fluxo". Por mais esta razão, a repressão ao varejo do tráfico na Cracolândia é contraproducente. A renda obtida pela participação nas atividades de zeladoria é garantia de sustento do uso, além dos diversos outros gastos feitos a partir dela como visto neste livro. Mas esta renda é fundamental também para se evitar o padrão 
dos junkies de expedientes, ou pior ainda, do junkie de rua e promover a evolução do usuário para uma situação estabilizada. A ditadura do "corre", esta verdadeira maratona diária em busca de fundos para o consumo de crack, muitas vezes através de atividades com razoável grau de periculosidade como a prostituição e os pequenos furtos pode ser superada. Em seu lugar vem a remuneração semanal, previsivel e suficiente para um uso satisfatório do crack, sob o ponto de vista do usuário. Mesmo fazendo uso durante todo final de semana posterior ao pagamento, ele possui, como vimos acima, a expectativa de, em breve, ter novamente oportunidade de reiniciar o ciclo de uso, posterior a novo pagamento, ou mesmo de modificá-lo em outra direção. "Não tem nem tempo pra sair pra roubar" como muito bem observou o beneficiário Lucas.

A estrutura de vida, em praticamente todos os aspectos levantados por Grund, pôde ser trabalhada dentro do Programa DBA. Seu escopo cobre desde as atividades diárias passando pelas conexões, compromissos, obrigações e responsabilidades, até as condições psicossociais não relacionadas ao consumo de drogas e aos fatores socioeconômicos, assim como os culturais. Os dias passaram a ter uma cadência regida pelas três refeições diárias, pelo horário de trabalho de zeladoria pela manhã e pelo sono noturno proporcionado pela acomodação dos beneficiários como hóspedes em hotéis da região. Para alguns, esta carga diária de atividades foi ampliada pela participação em cursos de formação profissional, como os de jardinagem disponibilizados na Fábrica Verde, além dos de informática, cabelereiro, entre outros. Acontecem em salas alugadas ao lado da primeira sede da ONG gestora do POT, além dos cursos ministrados no bairro do Tatuapé e na empresa Porto Seguro. Isto tudo corresponde a uma gama de obrigações e responsabilidades a estruturar, no sentido de ordenamento do cotidiano, a vida dos usuários de crack. Criam-se responsabilidades quanto 
a horário, aparência, vestimenta, higiene, manutenção e manuseio de material didático e de trabalho.

Ademais, vimos como Lucas percebe com clareza o momento socioeconômico atual do país e mais especificamente o de sua classe na cidade de São Paulo. Não faltam postos de trabalho. Este quadro de plena empregabilidade imprime nos beneficiários mais um ânimo para permanecerem no programa e dedicarem-se aos cursos oferecidos, dada à certeza do emprego no final do processo: hospedagem - trabalho/curso - trabalho formal. Além disso, é claro, devemos lembrar a profunda mudança iniciada pelo Programa DBA sobre a compreensão do uso do crack por parte da sociedade paulistana, por exemplo, ao ver seu prefeito cumprimentando, dialogando, empregando e planejando ações com estes mesmos usuários.

Em uma foto tirada pelo autor deste livro em junho de 2014, o prefeito aparece abraçando uma beneficiária e uma agente socioeducativa de Smads. Ele está sem gravata, após ter vistoriado conjuntamente com o governador do estado Geraldo Alckmin a nova Praça Coração de Jesus, em seguida a sua inteira reforma feita por uma empresa de seguros com vários edifícios no bairro. Os policiais militares vistos atrás do prefeito foram responsáveis pela guarda pessoal do governador e também lá se encontravam por naquele local estar se inaugurando um posto da polícia militar, sucedendo um posto da guarda civil metropolitana desativado após ser depredado no final de 2013. Ao lado da beneficiária, com o uniforme azul das equipes de zeladoria (as de jardinagem possuem uniforme marrom), está o então responsável pelo almoxarifado da Adesaf e atrás da beneficiária, uma assistente social de Smads. Ao lado da agente socioeducativa encontra-se o ex-subprefeito da Sé, região do Programa DBA, Mauricio de Góis, posteriormente, representante da Secretaria de Governo no Programa. Durante sua estada na praça e arredores, o prefeito cumprimentou inúmeros beneficiários, conversou com outros, tirou 
muitas fotografias e conheceu as novas instalações de salas de aulas ao lado da ONG gestora do POT. Também foi reunir-se brevemente com a equipe da saúde na sede do programa, localizada na rua Helvétia.

Sobre o aspecto, importante para o modelo de Grund, relacionado ao preço e qualidade da pedra de crack, podemos afirmar que estes permaneceram constantes após o início do Programa DBA, porém, com o uso mais intenso sendo relegado aos finais de semana, próximos aos dias de pagamento.

Ao se aproximar do final do ano de 2014, o local reservado ao "fluxo", em frente à sede do DBA, foi novamente ocupado por barracos. Contamos 25 em média. Os barracos mais externos eram reservados ao descanso e uso do crack, porém, havia uma espécie de corredor formado por barrados a poucos metros de onde se localizava o ônibus da GCM e suas câmeras. Neste corredor, há intenso comércio de crack. Vimos que, os "disciplinas" do PCC eram cotidianamente acionados para a solução de todo tipo de ocorrências na Cracolândia, o que inclui os problemas no interior do próprio Programa DBA, como ameaças a equipe técnica ou aos orientadores e desavenças de todo tipo. Disto decorreu que estes "disciplinas" e mesmo o crime organizado tenham se empoderado no processo e assim, conseguido impor a volta dos barracos e do tráfico em maior escala. Ao mesmo tempo, o prefeito Haddad cobra do governo estadual que impeça a chegada do crack à Cracolândia. É nesta difícil relação que podem residir os problemas que surgirão no futuro próximo. Pois o barraco, neste caso como nos demais descritos neste livro, serve como local protegido e acolhedor, porém, sua retirada esteve no centro político/midiático da implantação do Programa DBA. Seu retorno deverá colocar a legitimidade do Programa em cheque perante a cidade. 


\section{"O JOGO TÁ PEGADO": TIMES E CAMPEONATOS DE FUTEBOL COM JOGADORES USUÁRIOS DE CRACK NA REGIÃO CENTRAL DA CIDADE DE SÃO PAULO}

Um lema marcou a prevenção ao abuso de drogas na década de 1980: "Esporte não é droga. Pratique." Esta visão possivelmente se associava ao caráter disciplinar das práticas esportivas caudatárias do ocaso do Regime Militar. No findar desta década, Carvalho \& Carlini-Cotrim (1992) fizeram uma ampla pesquisa entre estudantes de ensino fundamental e médio de 15 capitais brasileiras sobre a prática de atividades não curriculares e o consumo de álcool e drogas; não encontraram nenhuma associação entre a diminuição deste consumo e a prática de esportes, artes e atividades comunitárias. A única correlação negativa perfeita foi obtida entre participantes em atividades sindicais na cidade de Salvador. A ideia central das campanhas que vinculavam a prática desportiva com a diminuição do consumo de álcool e outras drogas era a de se "tirar os jovens do ócio e das ruas", porém, para as autoras “[...] conceber o tempo livre como propiciador de comportamentos de risco" [...] implicaria "na identificação do estudante pobre, que gasta seu tempo livre nas ruas, como um sujeito potencialmente drogado". (CARVALHO; CARLINI-COTRIM, 1992, p. 147) Não se trata, para as autoras, de se ocupar o tempo de modo não voluntário como forma de prevenção ao abuso de drogas, mas de se:

[...] deslocar a discussão do 'fazer x não fazer' para a do como fazer, tendo como pressuposto que um jovem realizado em suas potencialidades (e não apenas ocupado, ou assimilando padrões e códigos) deve ser a meta adequada de programas que visem à saúde mental do adolescente. A ânsia de ocupar o jovem a qualquer custo passa, nesta perspectiva, a ser substituída pela preocupação com a qualidade - em termos de vivência, criatividade, espaço para questionamento que atividades não curriculares 
possam vir a oferecer. (CARVALHO; CARLINI-COTRIM, 1992, p. 148-149)

Não trataremos, neste capitulo, de prevenção ao abuso de drogas, mas do trabalho com usuários em oficinas de futebol. Porém, a pesquisa de Carvalho e Carlini-Cotrim (1992) nos é útil para evitarmos uma visão instrumental e ingênua do esporte como instrumento de prevenção, ou no nosso caso, porta de saída do uso abusivo de drogas, mais especificamente o crack. Veremos aqui, a partir da descrição proporcionada pela pesquisa etnográfica, como o futebol, e particularmente os sentimentos de equipe possibilitados pela absorção no jogo, o enquadramento e as regras de irrelevância, dá oportunidade para o trabalho do orientador socioeducativo - aqui designado pela denominação utilizada pelos nossos interlocutores "professor" - abrir espaço para um aumento do autocontrole por parte dos jogadores sobre seu padrão de uso de álcool, crack e outras drogas devido a mudanças em sua estrutura de vida. ${ }^{122}$

Cinco jogadores uniformizados de cada lado e um juiz, numa quadra coberta de futebol de salão. Nas laterais do campo, o técnico grita frases de orientação tática e técnica: "Sai da marcação"; "Vem, vem, vem"; "Espalha aí, vamos jogar aberto"; "Ó a marcação aí, ó". Determinado momento, resolve orientar de modo individualizado: "Levanta a cabeça, Paraná"; em outro, de modo um pouco mais incisivo: "Vamos fazer gol, caralho!". Nada que não possa ser encontrado em uma escolinha de futebol, ou em um colégio durante a aula de educação física. Porém, quem admirasse a partida poderia perceber alguns aspectos intrigantes no desenrolar das jogadas. A primeira delas é o fato do técnico ser responsável por ambas equipes em campo, durante este jogo/treino. Até este ponto, nada haveria de tão extraordinário, mas, talvez a presença de um jogador trajando boné, óculos escuros e fones de ouvido fosse algo a

122 Aqui entendida segundo as pesquisas de Grund (1993). 
despertar maior curiosidade. Mais ainda, se este jogador perdesse a oportunidade de marcar um considerável número de gols por, aparentemente, procurar dar a eles um tom a mais de brilho, um toque a mais de plasticidade, de beleza e mesmo certo "quê" de comicidade, isto causaria ainda mais interesse no observador. Este jogador é Paraná, constantemente advertido pelo "professor" quanto a sua postura corporal. Em breve veremos porque Paraná nos é tão importante.

Ainda assim, a singularidade desta partida está longe de ser desvendada. Para tanto, precisariamos fazer um duplo movimento. Um para fora e outro no sentido inverso. O primeiro nos mostraria o contexto no entorno da quadra de futebol e o segundo, quem eram aqueles jogadores minutos antes do início da partida e como estão após seu término. A quadra se situa em um centro de acolhida conveniado com a Prefeitura do Município de São Paulo, no bairro do Bom Retiro e é cercada por símbolos do cristianismo católico. Paraná é um ex- "pai de rua", termo conotativo daqueles responsáveis por algum tipo de atividade, muitas vezes ilegal, no ambiente das ruas e, geralmente, com sua autoridade imposta pela violência.

Ainda não é este o aspecto capaz de causar maior impressão naquele disposto a aproximar-se um pouco mais do cotidiano destes jogadores, este observador atento teria oportunidade de saber do uso cotidiano de crack pela quase totalidade dos envolvidos, inclusive Paraná. Assim como, por mais de uma década, também pelo técnico ou professor, um ex-usuário de crack e ex-morador de rua na região do centro da cidade de São Paulo, conhecida como Cracolândia. Um observador participante, caso desejasse mostrar suas habilidades em campo, ou simplesmente divertir-se em uma partida/treino de futebol com 10 minutos de duração ou dois gols marcados pela mesma equipe, correria o risco de sentir nas próprias canelas o ímpeto e vontade de vencer presente dentro daquelas quatro linhas. Nas palavras de Johan Huizinga "O que é primordial é o desejo 
de ser melhor que os outros [...] o principal é ganhar". (HUIZINGA, 1996, p. 58)

Vimos acima, uma breve introdução à nossa pesquisa de campo e a ela retornaremos muitas vezes mais. Porém, se faz oportuno iniciarmos abaixo nossa entrada numa das bases teóricas deste capítulo.

\section{Fun in games}

Erving Goffman e Robert McGinnis publicaram em 1961, um livro com dois estudos intitulado Encounters: two studies in the sociology of interaction. O trabalho que particularmente nos interessa nesta obra é Fun in games. O paper versa sobre quão longe alguém pode ir por tratar a diversão seriamente. Como supracitado, não obstante as brincadeiras de Paraná, o jogo é "pegado". ${ }^{123}$ Para estes autores, os jogos são um tipo específico de encontro focado; envolvem um foco visual e cognitivo único de atenção. Enquanto estão na quadra, Paraná e demais jogadores encontram-se imersos em um ambiente capaz de intensificar a relevância mútua de seus atos, assim como de maximizar a oportunidade de cada participante perceber o monitoramento do outro sobre ele. "Jadiel pipoqueiro!", grita um jogador irritado com certo tipo característico de comportamento em campo, marcado pela perceptível falta de comprometimento em participar ativamente das jogadas mais duras. "O cara tá cobrando lateral com a bola rolando", protesta certo jogador ao ver outro, da equipe adversária, desrespeitar uma regra básica do futebol de salão. "Não pode sair assim", do professor a um jogador que abandona o treino em andamento.

Este monitoramento promove uma abertura mútua à comunicação e possibilita a emergência de um "nós racional" (GOFFMAN; MCGINNIS, 1961, p. 18) como um senso de coi-

123 Termo êmico utilizado para designar uma partida muito disputada de futebol. 
sa única que "nós" estamos fazendo naquele momento. Além disto, tanto quanto estes encontros focados consigam prover a base de comunicação para um fluxo circular de sentimentos entre os participantes, conseguirão dispor a eles compensações corretivas para atos desviantes. "Cada um no seu, cada um no seu. Tem dois caras sobrando aqui (sem marcação)", diz um jogador ao time.

Vamos falar um pouco de Maradona, um acolhido ${ }^{124}$ e participante da oficina de futebol, também ex-jogador profissional de pequenas equipes da região de Sorocaba, cidade próxima a capital paulista. Ele chegou a jogar com o jovem jogador profissional de fama internacional, Robinho, antes deste se tornar craque da equipe do Santos F. C. Maradona, certo treino, apresentou-se "cheiradaço", nas palavras do professor e logo ao iniciar a primeira partida daquela tarde, ele lhe chama a atenção. Assim, Maradona permanecerá recebendo comentários sobre seu estado e de como está prejudicando sua equipe até o fim da segunda partida e também coincidentemente ou não, de sua segunda derrota. "Deixou seu time na mão, hein, Maradona", brada o professor após levantar a camisa dele e comentar sua magreza, mesmo tendo o jogador convertido um gol de pênalti. Sobre o comportamento da equipe com Maradona, o professor observa: "Os caras mesmo cobram dele". Coincidentemente, naquele exato momento, ao lado da quadra, Maradona realmente era chamado à atenção. Goffman e McGinnes (1961) devotam especial atenção aos adictos, ou usuários de álcool e drogas e sua possível dificuldade em manejar seu estado de modo discreto quando sob efeito destas substâncias, sem contagiar as obrigações de interação para que o encontro focado, como é o caso da partida esportiva, possa manter sua fronteira.

124 Termo técnico utilizado pelos orientadores socioeducativos e demais profissionais dos equipamentos destinados a abrigar a população em situação de rua para referir-se a esta população quando atendida. Para aqueles usuários apenas dos serviços da Tenda, o termo utilizado é convivente. 
Voltemos a Paraná, o ex-pai de rua, veremos agora como certas propriedades dos participantes, como ser ex-pai de rua, serão tratadas pelas regras de irrelevância como se não estivessem presentes. Uma atividade engajadora como é o jogo de futebol em geral e particularmente entre nossos interlocutores é capaz de agir como uma fronteira em torno dos participantes, vedando-os dos muitos mundos potenciais de significado e ação. Sem esta barricada abrangente, presumivelmente, os participantes estariam imobilizados por uma inundação de bases para a ação. Em um encontro focado, como são os jogos de futebol, as regras de irrelevância nos falam sobre aquilo a ser ignorado e por consequência o que deve ser tratado como real. Elas tornam possiveis uma matriz de acontecimentos relevantes, ou eventos ligados ao jogo, envolvidos em um esquema de expressão e interpretação, assim como possibilita papéis e identidades geradas pelo jogo. Desta maneira, Maradona não poderia invocar sua condição de ex-jogador para ser escalado em um campeonato, sua antiga condição e qualquer importância dada a ela é irrelevante frente ao mau desempenho em campo.

Mesmo o professor ${ }^{125}$ é cobrado de acordo com o papel exercido na partida e caso esteja como juiz ou treinador poderá ser questionado ou chamado à atenção. Maradona, ao constatar a segunda derrota de seu time acusa o juiz/professor de ter "roubado". Em outra oportunidade, ao comentar a escalação para um campeonato no qual participaram equipes de acolhidos, de conviventes e de orientadores socioeducativos, Maradona questiona os critérios adotados na montagem das equipes: "Na cabeça dele de técnico, ele pensou que iria fazer o nome com o outro time e deixou nóis [sic] sem reserva". Ainda em outra

125 Colocado nesta posição por ser orientador socioeducativo em um equipamento público voltado à sociabilidade da população de rua, oficialmente designado como Tenda e por ter escolhido o futebol como recurso de trabalho com esta população. 
circunstância ao conversar distraidamente comigo, o professor é advertido por um jogador em campo, de estar demasiadamente absorto pela nossa conversa e não com o desenrolar dos acontecimentos da partida. Ele recebe o aviso: "Você não está vendo o jogo, não?”. O juiz, certamente é um recurso percebido, ou seja, para Goffman e McGinnes (1961), ele faz parte dos eventos e papéis percebidos localmente, como também são os papéis de técnico e jogador.

Paraná, quando não está jogando futebol de salão é pai de rua $^{126}$, mas dentro de quadra é um jogador alegre dado a enfeitar suas jogadas. Depois de desperdiçar algumas oportunidades, seu gol é especialmente comemorado pelos colegas. Em outra ocasião, ao término de uma série de partidas/treino, ele chega a declarar com uma "alegria insopitável e gratuita" (RODRIGUES, 1994, p. 80) e afirma que: "Hoje foi bom demais. Nós viemos pra brincar". O jogo permite a expressão de uma faceta jocosa, por certas vezes ele não ser tão "pegado" assim. ${ }^{127} \mathrm{Na}$ ocasião da frase acima, dita por Paraná, os gols sequer foram contados. Além disto, por não ser o jogo semelhante à rua, as regras de irrelevância ${ }^{128}$ não permitem às maneiras de pai de rua furar a barreira e adentrar na quadra. Possivelmente por esta razão, Paraná seja considerado o jogador exemplo pelo professor. Antes de começar a jogar futebol, "criava problema e arranjava briga no albergue”. As regras de irrelevância obrigaram, ou criaram a possibilidade para que, no jogo, o ex-pai de

126 Paraná era líder de uma "maloca", nome dado ao tipo de moradia assemelhada ao cortiço, com dezenas de pessoas ligadas a ele. Certo dia envolveu-se com a esposa de um rapaz recém preso e foi expulso violentamente.

127 Não é em qualquer ocasião que esta condescendência está presente. Em outro treino com jogos mais "pegados", um jogador que tentou fazer gols com excesso de dribles foi ridicularizado como "Neymar do crack", "Neymar do tráfico" e "Neymar do fluxo".

128 As regras de irrelevância permitem o enquadramento pelo jogo dos aspectos apropriados da realidade e o descarte dos demais, assim como parece existir para deixar algo dificil ser silenciosamente expresso tanto quanto ser totalmente excluído da cena. 
rua transmutado em jogador demonstre, sob o monitoramento e sanção da equipe, apenas seus atributos ligados à diversão, ou ao bom desempenho do time. Os modos de pai de rua não ajudam a marcar gols e o jogo de futebol compreende uma gama de situações dificeis que cada jogador estará sob risco de encarar. Também demanda as qualidades de mente e corpo que ele precisará para enfrentar bem estas situações. Por isto, é apenas no futebol, por exemplo, que "o zagueiro tem que ter o tempo da bola” (CAVALCANTE, 2011, p. 98), estas qualidades chegam a estar descritas nos manuais de educação física. ${ }^{129}$ Desta maneira, o jogo de futebol parece encaixar-se nestas observações feitas por Goffman e McGinnes (1961) sobre encontros focados como algo destacado da vida ordinária.

Uma matriz de possíveis eventos e um elenco de papéis por cuja sanção o decorrer dos eventos constitui em conjunto um campo para uma fatídica ação dramática, um plano de existência, uma máquina de significado, um mundo nele mesmo, diferente de todos os outros mundos exceto os outros gerados quando o mesmo jogo é jogado novamente. (GOFFMAN; MCGINNIS, 1961, p. 26-27, tradução nossa)

Percebemos então, como o futebol consegue gerar um mundo diferente do mundo da rua e do uso do crack, mesmo tendo jogadores daí advindos. Seus "movimentos corporais performados localmente" (GOFFMAN; MCGINNIS, 1961, p. 28) são enquadrados pelo jogo e caso não sejam apropriados são descartados da realidade pelas regras de irrelevância, quase como uma corporalidade enquadrada.

Os jogos nos separam da vida ordinária e nos imergem em mais uma de suas possibilidades, eles nos dão a chance de

129 "Os zagueiros centrais (ou zagueiros de área). Física: Estatura elevada, agilidade, força, impulsão, bom porte físico, equilíbrio, reação rápida. Psicológicas: capacidade de liderança, coragem, calma, muita decisão, combatividade, maturidade”. (BOSARI, 1989, p. 15) 
vivermos outras realidades nas quais eventos visiveis irrelevantes serão ignorados; assuntos privados irrelevantes serão mantidos fora da mente e uma inconsciência sem esforço poderá se apoderar de nós. (GOFFMAN; MCGINNIS, 1961) A perspectiva de jogo reduz a situação a times, um lado do qual passamos a ser o jogador, um agente do jogo que age e faz, não para uma individualidade, mas para uma equipe com quem se compartilha uma identidade de interesse. A atividade básica de um jogo é o movimento, cada um selecionado entre limitado número de possibilidades e sendo largamente determinado pelo movimento prévio do time oponente. O conceito de interação é assim transformado, para Goffman e McGinnis (1961) refere-se agora a uma forma altamente estruturada de destino mútuo.

Este destino mútuo pode ser percebido nas orientações e admoestações do professor referindo-se a comportamentos pouco producentes em campo, mas aparentemente, além disto, inadequados a um ambiente quase familiar: "Vamos parar de xingar aí e jogar mais futebol". Ou, ao ter de dar socorro a um jogador objeto de uma falta mais dura: "Devagar aí, tamo [sic] em família".

O envolvimento completo produzido pelo jogo, apesar de sua trivialidade, pode transformar qualquer participante em um antagonista digno, malgrado grandes diferenças de status social e das possiveis reivindicações de prestígio advindas de outras realidades sociais. (GOFFMAN; MCGINNIS, 1961) A história do futebol no Brasil é a própria confirmação desta idéia. No início do século XX, o futebol se tropicalizava no Rio e em São Paulo, deixava de ser privilégio de jovens abastados e satisfeitos em copiar o estilo inglês de jogar para ser "fecundado pela energia criadora do povo que o descobria". (GALEANO, 1995, p. 39) Os usuários de crack também encontraram no futebol e na disputa de campeonatos, oportunidade de, uniformizados e com o desempenho enquadrado pelo jogo, serem reconhecidos socialmente. 
O envolvimento é uma possibilidade aberta pelo jogo. O monitoramento mútuo objetiva impedir o livre desenvolvimento da jogada pelo adversário e promover o jogo realizado pela própria equipe. Faz deste envolvimento, uma obrigação a ser sustentada em dada medida; nem exageradamente, nem pouco. Ademais, este envolvimento espontâneo compartilhado em uma atividade mútua coloca os parceiros em algum tipo de solidariedade exclusiva e permite a eles expressar companheirismo, proximidade psíquica e respeito mútuo; a falha em participar de boa vontade pode ser interpretada como expressão de rejeição aos presentes ou ao contexto. (GOFFMAN; MCGINNIS, 1961) Não seriam então, sem motivo as declarações de um usuário de crack sobre sua antiga equipe do albergue: ${ }^{130}$ "O time faz a gente gostar mais um do outro. Quando alguém fazia dívida, a gente ia lá e pagava. Eu não usava drogas naquela época e sobrava um dinheirinho com que eu comprava refrigerante pra todo mundo [...] um aprende a respeitar mais o outro". Enfim, é o envolvimento de outras pessoas, apesar do possível vazio de interesse de alguém, o fiador da absorção.

Ademais, parece não haver agente mais efetivo que outra pessoa para tornar um mundo vivo para alguém ou, por uma olhada, um gesto, ou uma observação, ativar a realidade em que alguém esteja alojado. É somente nos encontros face a face que quase tudo pode vir a ser base de uma perspectiva e definição de uma situação. (GOFFMAN; MCGINNIS, 1961, p. 41)

Para Goffman e McGinnes (1961), em uma teoria do jogo, a mais importante propriedade do ponto de vista da interação é a

130 O grupo passou a ter dificuldade em unir a equipe para os treinos e chegou ao fim com a mudança de jogadores que saíam do equipamento público destinado a abrigar a população em situação de rua. Este mesmo usuário acabara de formar-se no Programa Nacional de Acesso ao Ensino Técnico e Emprego (Pronatec) e estaria dando início em um emprego para trabalhar com reciclagem em uma grande rede de supermercados, naquela semana, primavera de 2013. 
"natureza psicobiológica orgânica do envolvimento espontâneo" (GOFFMAN; MCGINNIS,1961, p. 38), o engajamento espontâneo do indivíduo em uma atividade capaz de produzir certa empolgação apropriada a conduzi-lo para uma absorção visual e cognitiva e, por uma inatenção seletiva, à despreocupação com eventos outros que não a atividade. O participante torna-se, assim, parte integral de uma situação governada tanto pelas regras do jogo, ${ }^{131}$ quanto pela estrutura do encontro. Esta estrutura é responsável pela automobilização através da qual o movimento enquadrado pelas regras é executado. Para aprender sobre a estrutura dos encontros focados podemos examinar o que acontece quando seu ordenamento é quebrado e como certa definição da situação exclui determinadas perspectivas quando é satisfatoriamente sustentada.

Os encontros face a face possibilitam a um não humano, como o apito do professor/juiz, definir circunstâncias de plena absorção pela situação do jogo, como uma falta ou um gol anulado. "Pessoal, vamos ouvir o apito", grita constantemente o professor ao fazer as vezes de juiz em um treino. Em determinado momento, ele vira em minha direção e comenta: "Cara, você não faz ideia do que o apito significa para eles em termos de autoridade, limite".

O material esportivo, no qual se incluem os uniformes, ficam também sujeitos às regras que estruturam o jogo, segundo Goffman e McGinnes (1961). Os uniformes são parcela importante do esforço por um disfarce próprio ao encontro focado e distinto da seriedade da vida. Os significados relevantes ao jogo das várias peças do equipamento são neles mesmos um disfarce útil. Assim sendo, por detrás destes significados, os valores sentimentais, materiais e estéticos das peças podem atuar dentro da interação com tons de significado que nada tem a ver com a lógica do jogo, mas relacionadas com o prazer do encontro. Igualmente, a maleabilidade dos arranjos de

131 Veremos abaixo, como as regras do jogo também podem ser manipuladas. 
jogo - escolha dos jogos, lados, dificuldade, apostas - permite a fabricação da quantidade certa de disfarce e uma descontinuidade com o mundo é alcançada mesmo quando uma conexão com ele é estabelecida.

Não obstante o envolvimento de outras pessoas no jogo, a percepção que algum participante não está espontaneamente envolvido na atividade mútua pode desacreditar a identidade imputada a ele como alguém capaz e pronto para imergir-se em um encontro, assim como pode enfraquecer, do ponto de vista dos demais envolvidos, sua própria absorção no encontro e a crença na realidade do mundo prescrito. Um desvio percebido da norma pode ainda ter um efeito "multiplicador", infectando todo encontro.

A organização do encontro fornece as concepções dos participantes concernentes a sua identidade, assim como a toda identidade da ocasião social da qual o encontro é visto como parte. (GOFFMAN; MCGINNIS, 1961) Veremos abaixo, como a sobreposição da identidade de "vapor" e a de goleiro, trazida a tona por um evento do jogo, pode colocar em xeque o eixo organizacional do encontro. As identidades organizadoras da interação são ameaçadas de serem desacreditadas ou suplantadas pelos problemas causados por certos eventos que não acrescentam meramente um ruído disruptivo. Mesmo considerando, com Goffman e McGinnes (1961), que de todas nossas capacidades, aquela para envolvimento espontâneo parece ser a menos sujeita a controle consciente. Tais eventos, ainda que pequenos, podem enfraquecer todo o desenho do encontro, deixando os participantes confusos sobre o que fazer a seguir, ou o que tentar ser posteriormente. Veremos a seguir como em um encontro de equipes de futebol de diversas Tendas, ${ }^{132} \mathrm{um}$

132 Tendas são os espaços de convivência e atendem: [...] a função de "porta de entrada" que possibilite o atendimento às necessidades básicas da pessoa em situação de rua e vulnerabilidade social como higiene pessoal, oferecendo banhos, cortes de cabelo, lavagem de roupas, atendimento com assistentes sociais, psicólogos e encaminhamentos das diversas deman- 
evento pôde colocar em risco a identidade dos participantes, as barreiras a bens externamente percebidos e até o próprio encontro.

\section{Um "incidente"}

Incidentes são aqui entendidos como os episódios capazes de ameaçar, pelo conflito, o enquadramento do encontro. "Durante um encontro, eventos podem ocorrer, tanto intencionais ou não, que repentinamente aumentam o nivel de tensão". (GOFFMAN; MCGINNIS, 1961, p. 45) O Intertendas é um campeonato e reúne times de acolhidos e de funcionários. ${ }^{133}$ Acolhido, como vimos, é o termo nativo e "técnico" para designar aqueles hóspedes ${ }^{134}$ em algum equipamento público municipal ou conveniado dedicado a abrigar a população em situação de rua. São os participantes do encontro, pessoas pertencentes à parcela da população de rua frequentadora de alguma oficina de futebol sob responsabilidade de um orientador socioeducativo. Este é contratado pela entidade gestora do equipamento sem concurso público e, portanto, não faz parte dos quadros estáveis do funcionalismo. Também participam times de orien-

das que ali cheguem. É um equipamento da rede sócio assistencial que permite ao individuo a oportunidade de reestabelecer seus vinculos antes fragilizados ou rompidos [...] Desta forma, o orientador socioeducativo presente em todas essas dinâmicas, faz dessa relação, instituição-população, uma relação pautada pela horizontalidade, pelo vinculo, que rompe com o distanciamento conservador, moralista e excludente, potencializando a relação de aproximação, de igualdade, de força de vontade e mais ainda da perspectiva de saída, do processo de institucionalização, saída reintegrativa, emancipada e autônoma. (COMPLEXO PRATES, 2014)

133 Entendemos como funcionários, os orientadores socioeducativos.

134 Ao observador não pertencente à área do serviço social, o uso do termo "acolhido" não apenas pelos funcionários, mas como termo técnico, correto e oficial, soa como pertencente a uma lógica caritativa. A instituição acolhe, o hotel hospeda. Na rede hoteleira, o hóspede paga, escolhe e decide, em uma lógica de prestação de serviço. Nos Centros de Acolhida não há instâncias locais formais de participação, de fato, dos atendidos, nem na gestão dos equipamentos, tão pouco na fiscalização dos gastos executados com as verbas municipais que os mantém. 
tadores socioeducativos dos equipamentos públicos dedicados à população em situação de rua. Tanto funcionários quanto acolhidos, porém, com maior intensidade os últimos, circulam pelos diversos equipamentos, travando ai, relações sociais relativamente duradouras e por vezes conflituosas. A quase totalidade dos acolhidos e conviventes envolvidos nas oficinas de futebol são usuários de crack, segundo informação dos orientadores socioeducativos; confirmada pela pesquisa de campo.

Os conviventes e acolhidos haviam participado de ao menos uma reunião de preparação do Intertendas, ${ }^{135}$ porém, a montagem das chaves com a ordem dos confrontos foi feita apenas momentos antes da primeira partida, por sorteio. Este processo leva algum tempo, assim como o atrazo de algumas equipes fazem com que muitos jogadores fiquem ansiosos, portanto, o primeiro jogo começa tenso e muito disputado. Os orientadores socioeducativos dirigem suas equipes, mas isso não impede a ocorrência de um conflito nos primeiros instantes da partida inicial, impondo a intervenção dos orientadores e do juiz. Este último, tão pouco é funcionário de carreira do município, mas nos dizeres de um orientador é "um batalhador pelo esporte".

A primeira partida é entre equipes de acolhidos e conviventes. As cobranças sobre a defesa do time que se encontra em desvantagem no início do segundo tempo são grandes. O campeonato é disputado em partidas de dois tempos de 15 minutos. Uma das equipes está particularmente nervosa e um jogador precisa ser contido pelo orientador socioeducativo/professor. ${ }^{136}$ A seguir, em uma jogada mais dura, este jogador nervoso desde o início da partida inicia uma discussão acalorada com o goleiro Ronaldo da equipe adversária e o leva (Ronaldo) à expulsão. Ouço de um participante torcedor ao meu lado:

135 Nome dado aos campeonatos de futebol que reúnem times dos centros de acolhida e de convivência municipais.

136 Impressiona-me o fato de o juiz apitar com um copo de água na mão. 
“O jogo tá pegado, ${ }^{137}$ hein mano?". No momento da confusão todas as equipes interviram, a comoção foi geral. No decorrer da partida, dois jogadores da reserva são advertidos pelo juiz e ameaçados de serem expulsos caso não cessem de "tentar apitar o jogo". Nos próximos jogos, o papel de juiz será desempenhado também pelo motorista de uma das Kombis responsáveis pelo transporte, assim como por funcionários e orientadores socioeducativos. ${ }^{138}$ Durante os intervalos do jogo, os orientadores socioeducativos dão orientações técnicas aos seus jogadores. No decorrer das partidas, o goleiro expulso no primeiro jogo pôde voltar a atuar por outras equipes. Suas boas defesas são comemoradas com aplausos de sua equipe e da torcida em volta da quadra.

Uma disputa para semifinalista é feita nos pênaltis e Ronaldo fez grandes defesas, além de marcar vários gols cobrando pênaltis. Como o empate permanece após todos os jogadores dos dois times terem batido seus pênaltis, novas regras são acordadas $^{139}$ a cada novo empate, até o ponto de Ronaldo bater pênaltis seguidos. Ele é o grande responsável pela vitória de uma equipe de acolhidos. Enquanto os pênaltis são cobrados, as funcionárias do albergue deixam suas atividades de trabalho e juntam-se ao encontro como torcedoras do time da casa. As funcionárias da cozinha abandonam seus afazeres e dirigem-se uniformizadas à quadra para torcer. No decorrer dos jogos, não foi incomum jogadores atuarem em mais de uma

$137 \mathrm{Ou}$ absorvente como diriam Goffamn e McGinnes, ou ainda Clifford Geertz sob sua influência. (GEERTZ, 1989)

138 Pudemos perceber, entre os que trabalham com a população em situação de rua, certa visão sobre seu papel em contato direto com os acolhidos nas dependências dos equipamentos públicos e conveniados. Embora o cargo de orientador socioeducativo apareça ligado, particularmente, aos serviços destinados ao atendimento de jovens, adultos e idosos (SECRETARIA MUNICIPAL DE DESENVOLVIMENTO E ASSISTÊNCIA SOCIAL, 2010), o termo orientador socioeducativo é comumente atribuído a todos os funcionários não técnicos com trabalho diretamente ligado aos usuários destes serviços.

139 Discutiremos abaixo, como estas regras são manipuladas. 
equipe e enquanto esperam sua vez de jogar, muitos aproveitam para almoçar.

O professor cujos treinos assistimos conversa comigo e atribuiu certa vantagem aos jogadores das equipes de orientadores socioeducativos por eles terem dormido bem à noite, enquanto alguns membros dos times de usuários (acolhidos e conviventes) passaram a noite, ou parte dela, em claro, usando drogas. Sou informado, durante um jogo, da decisão tomada na reunião de preparação deste Intertendas ${ }^{140}$ sobre a distribuição dos troféus de primeiro, segundo e terceiro colocados, melhor jogador e melhor goleiro. Possivelmente, devido ao incidente descrito a seguir, se esqueceu, no final da competição, de premiar jogador e goleiro.

Chegando a semifinal, um orientador socioeducativo questionou os escolhidos entre os acolhidos para compor a equipe adversária a sua, por considerá-la uma composição de jogadores de diversos times de albergados. ${ }^{141}$ Este time teria incorporado os melhores jogadores de outras equipes. Por não ter jogadores reservas, ou por apresentarem pior condicionamento fisico, certas equipes de acolhidos e conviventes ficam visivelmente mais cansadas em campo. A despeito das queixas quanto à composição da equipe, Ronaldo, o goleiro expulso na partida anterior, pôde retornar. Esse mesmo goleiro foi aluno do Programa Nacional de Acesso ao Ensino Técnico e Emprego (Pronatec) ${ }^{142}$ e utilizava sua carteira de estudante para livrar-se de abordagens policiais. Sua camisa de goleiro destoava um pouco do restante do uniforme da equipe por aparentar melhor qualidade e ser mais nova.

140 Intertendas é o nome do campeonato entre equipamentos dedicados ao atendimento da população em situação de rua.

$141 \mathrm{Nem}$ todos os jogadores estão em albergue. Embora, algum jogador possa ter dormido aquela noite na rua, eles possuem algum tipo de vínculo com o sistema, ao menos frequentam a Tenda.

142 O Pronatec é uma iniciativa do Governo Federal, iniciado 2011, para oferecer cursos de educação profissional e tecnológica. 
Existe uma solidariedade dos acolhidos e funcionários entre si e outra de base local, não relacionada à posição no interior do sistema de acolhimento. Assim, o acolhido de determinado albergue pode torcer pela equipe de funcionários deste equipamento, caso não exista um time de acolhidos para quem possa torcer. As preferências parecem guiar-se mais pelos vínculos pessoais que pela categoria.

O time de funcionários da casa, invicto há mais de cinco anos, ficou muito abalado com a derrota e um torcedor desta equipe, também orientador socioeducativo da casa, procurou justificar alegando o cumprimento de plantão na noite anterior, por alguns jogadores de seu time. Quando brinquei dizendo que os jogadores da Barra Funda, acolhidos e conviventes, também poderiam ter farreado por toda noite, ele sorri.

Na semifinal, em uma disputa de bola mais acirrada, Ronaldo tomou as dores do jogador de seu time de acolhidos que sofreu uma falta e avança sobre o orientador socioeducativo que havia tentado, anteriormente, impedi-lo de jogar e com quem havia tido desentendimentos pregressos na Tenda onde este orientador socioeducativo trabalha. Ronaldo foi expulso e precisou ser retirado pelo professor e levado em direção à saída lateral, localizada no fundo da quadra que dá acesso ao refeitório e banheiros. Ele aparentemente não se conformou com a expulsão e retorna carregado pelo professor por outra porta lateral mais próxima da saída do albergue, gritando ameaças ao orientador socioeducativo com quem teve desentendimentos e se dizendo "do crime". Nisto, é ridicularizado pelos outros participantes e segue até a rua, em uma confusão que toma conta de toda quadra e torcida. Um acolhido comenta: "Só porque vende uns papéis lá em cima, pensa que é marginal”. Este mesmo jogador instantes depois iria cobrar uma atitude do professor: "Quem tem que botar disciplina nele é o Luciano".

Instalado o incidente, a primeira decisão tomada por uma freira e um orientador socioeducativo do albergue foi de encer- 
rar o campeonato naquele instante. Em seguida, ouvidos os apelos e verificando-se a grande frustração por parte dos participantes, decidiu-se esperar pelo término daquela partida, já iniciada, com a marcação da final para outra data. Caso o time de orientadores socioeducativos não vencesse a equipe em que Ronaldo jogava quando foi expulso, teriamos uma final entre dois times de acolhidos. O mesmo orientador socioeducativo responsável pela decisão de dar continuidade ao campeonato diz que Ronaldo "tem de saber que isto não pode acontecer" e que "não pode chamar cem pessoas para a briga".

$\mathrm{Na}$ final que acabou ocorrendo regularmente naquele mesmo dia, entre a equipe original de Ronaldo e uma de funcionários, percebo que estes se utilizam de jogadores de outras equipes de orientadores socioeducativos para tentar vencer a partida, procedimento que condenaram nas equipes de acolhidos e conviventes. O resultado da partida é um indiscutível seis a um para a equipe de acolhidos e conviventes, malgrado os esforços e substituições feitas no time adversário.

Para Goffamn e McGinnes (1961) ao término de um encontro, os ex-participantes podem imediatamente formar grupos menores e neles torna-se possivel expressar abertamente assuntos tabus, dando vazão não apenas a enredos segundários, mas a pós-jogos. ${ }^{143} \mathrm{Um}$ choque moral poderia ser invocado em decorrência dos atos impróprios observados por todos, como a atuação do goleiro, mas não é o que ocorre com os acolhidos e conviventes. Após o término do jogo, a discussão gira em torno das jogadas, gols e da alegria e orgulho em terem vencido o campeonato; não em torno do incidente. Sou escalado para tirar as fotos da vitória. Ao levantar a taça e ser fotografado, Maradona, escalado na equipe campeã, fez questão de que a inscrição no troféu "população de rua" saísse na foto: "Mostra aqui, ó, população de rua”. Na opinião do professor, os orien-

143 Nos pós-jogos se dá parte fundamental do trabalho feito pelo professor e será visto mais à frente. 
tadores se "comportaram mais como jogadores de futebol que como orientadores socioeducativos". Ele me confidenciou que teve de se ausentar do jogo por alguns instantes, devido a Ronaldo ter trazido uma arma para vingar-se e ter de ser dissuadido, e comenta: "Ele é 'vapor' e irmão de um 'irmão". ${ }^{144}$

Goffman e McGinnes (1961) tratam os incidentes como eventos ${ }^{145}$ possiveis de ocorrer durante um encontro e capazes de repentinamente aumentar o nível de tensão. Pessoas com estigmas sociais seriam especialmente vulneráveis a provocar contextos nos quais situações constrangedoras poderíam ocorrer. Uma palavra indiscreta seria suficiente para criar mal estar e em qualquer encontro focado, temas oficialmente irrelevantes são sucetiveis de irromper, como antigas rivalidades. Estes temas efetivamente drenam o foco e a atenção dos participantes, trazendo tensão à tona. Sob certas circunstâncias, como as relacionadas ao Intertendas, o indivíduo pode vir a ser inundado por tal fluxo de emoções que não mais consegue fazer uma exibição de conciliação. O evento pelo qual Ronaldo foi afetado, a falta grave, repentinamente o desobrigou de apoiar a interação. Mesmo que momentaneamente, ele deixou de se mobilizar para sustentar um papel expressivo e apropriado ao jogo de futebol e "transbordou". Ao irromper em raiva aberta, ele radicalmente altera seu apoio genérico à interação e se coloca momentaneamente "fora do jogo". (GOFFMAN; MCGINNIS, 1961, p. 55)

Este transbordamento constitui uma quebra no enquadramento e acrescenta um novo elemento distrativo ao contexto do encontro, para Goffman e McGinnes (1961) um transbordamento é geralmente sucetivel de constituir um incidente. Se pensarmos no Intertendas como tendo uma membrana metafórica em torno dele focalizando as preocupações, podemos ver que sua dinâmica está amarrada ao funcionamento da manu-

144 Irmão é o nome dado a quem pertence aos quadros diretivos do PCC.

145 Tanto aqueles provocados de modo intencional quanto os não provocados intencionalmente. 
tenção das fronteiras que o cortam seletivamente de mundos ampliados. Então, podemos começar a perguntar sobre os tipos de componentes do meio social externo ao encontro que irão contrair ou expandir o rol de eventos com que o encontro lida e os tipos de componentes que poderão tornar o encontro mais resiliente ou destruí-lo.

As diferenças de categoria entre funcionários e acolhidos ficam latentes até o momento em que um personagem intermediário, ou mesmo ambíguo como Ronaldo, é absorvido pela raiva. Ambíguo porque goleiro, ambíguo porque "vapor" e não simples usuário, ambíguo porque não dorme em albergues, mas em barraco e é responsável por um "espaço"146 na rua Paim, região central da cidade, mas próxima à Avenida Paulista e aos consumidores de droga mais abastados. Ele não se encontra na condição de acolhido, mas na de convivente.

No momento em que escrevo, Ronaldo se encontra livre, após período preso por tráfico de drogas. Ele possuía uma lista de clientes fixos e chegava a distribuir drogas a domicílio, se locomovendo por táxi pago pelos clientes. Quando pergunto a um seu amigo, semanas após o Intertendas, se Ronaldo teria defensor público, este amigo me responde, com ar de lesa-majestade, ser o advogado "particular". A atividade de "vapor" pode fornecer a estrutura de vida necessária para o uso controlado de drogas. Através do termo "estrutura de vida" que nos referimos a padrões regulares de atividades laborais, recreativas, domésticas e criminais que moldam e constrangem o dia a dia de usuários, assim como suas relações afetivas. (GRUND, 1993) Ronaldo mantém a mesma namorada há mais de cinco anos.

Práticas como "balancear times" (GOFFMAN; MCGINNIS, 1961 , p. 67), aquelas referentes à formação de equipes equi-

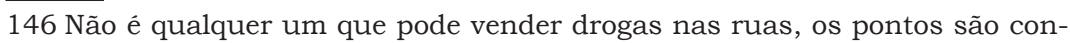
trolados pelo mesmo PCC do qual o irmão de Ronaldo tem uma posição relativamente importante. Quem recebe o espaço deve mantê-lo funcionando. É uma ocupação para todos os dias da semana. 
potentes, de dar desvantagens e limitar participantes a classes de habilidades introduzem maleabilidade suficiente nos materiais do jogo para conseguir que ele seja moldado e aperfeiçoado num modelo melhor adaptado a manter os participantes extasiados. A manipulação das equipes pelos participantes do Intertendas provocou uma controvérsia quanto às regras. Em Fun in Games, os autores apontam como a estrutura do jogo repousa sobre um ordenamento sancionado, base para que obrigações sejam cumpridas e expectativas realizadas. No Intertendas, nem as obrigações foram cumpridas e tão pouco as expectativas foram realizadas pelos jogadores, tanto funcionários quanto acolhidos e conviventes.

Nos equipamentos públicos são cotidianamente ofertadas vagas de emprego e em cursos como o Pronatec, assim como está sempre presente a possibilidade de mudança nas condições de acolhimento em uma progressão de centros de acolhida para hotéis sociais e bolsa aluguel. Neste sentido, o orientador socioeducativo responsável pela oficina de futebol fica atento à evolução do comportamento dentro de quadra, em busca de atributos relevantes externamente capazes de indicar capacidade e disponibilidade para as oportunidades de emprego e moradia. Isto faz da própria organização dos treinos e das convocações para participações em campeonatos instrumentos possibilitadores da máxima exibição dos atributos externamente relevantes e de sua avaliação pelo orientador socioeducativo.

A manipulação das equipes, supracitada, abre possibilidades e impõe limitações às pretensões do professor. Como vimos anteriormente, ele foi questionado por Maradona quanto à escalação das equipes sob sua responsabilidade no Intertendas. Teria privilegiado outro time, desclassificado no decorrer do campeonato, em detrimento do vencedor. Esta acusação objetiva retirar os méritos do técnico e depositá-los integralmente na equipe vencedora, apesar do técnico. O desafio do professor é conseguir balancear o máximo desempenho desejado com as 
individualidades. Para tanto, ele organiza treinamentos com a equipe selecionada para disputar campeonatos em datas separadas das oficinas abertas à participação de todos conviventes da Tenda, na qual o professor presta serviço como orientador socioeducativo.

Certa vez ouvi do professor em um treino: "Aí, Paraná. Você faz seu time". Ele falou em voz alta para todos ouvirem. Posteriormente, o professor nos declarou ser uma forma de provocar o envolvimento no jogo, atribuir responsabilidades. Em outra ocasião ainda, um jogador escalado para a reserva ameaçou sair da equipe caso não entrasse na partida. Esta partida era decisiva em um campeonato "de rua". ${ }^{147}$ Outros casos houveram de jogadores deixarem as equipes por não terem sua vontade de jogar atendida e com isso abandonarem os treinos. Isto inviabiliza o trabalho posterior do professor, como: tirar documentos, matricular em cursos e encaminhar a vagas de trabalho.

Se retornarmos ao assunto dos atributos relevantes externamente e da validade de se demonstrá-los internamente no jogo, poderemos perceber como Ronaldo, justamente por estar em uma posição dúbia, pôde catalisar em si, a oposição entre as categorias. Ele pôde, como convivente, tomar as dores do acolhido agredido em falta desleal por alguém de posição institucionalmente superior, um orientador socioeducativo. Porém, Ronaldo agiu contrariamente às regras de irrelevância que lhe requerem renunciar a ostentar seus atributos sociais externamente relevantes como ser "vapor", ou mesmo "do crime" e quando abertamente introduzidos, seus predicados não solici-

147 Os jogadores diferenciam campeonatos "de rua" e "de Tenda". Os primeiros envolvem times distantes do universo da população de rua. São campeonatos realizados na região central da cidade quando, eventualmente, usa-se a quadra de algum equipamento público para sua realização e por isso, chegam ao conhecimento das equipes estudadas. São particularmente, os campeonatos organizados pela colônia boliviana da cidade de São Paulo, em grande parte moradora da região central. 
tados pelo encontro focado acabaram por ameaçar a membrana ao redor do encontro.

Poderíamos dizer que a aposta de Ronaldo foi alta demais. Caso aceitasse sem reagir o que acreditava serem provocações dos funcionários contra ele, seria igualado aos acolhidos, sem voz e poder devido ao arranjo estrutural no qual estão inseridos. Nestas condições, um participante da partida transborda do encontro para jogar com uma preocupação ansiosa e privada. Para Goffman e McGinnes (1961), um jogador nestas circunstâncias é forçado a levar o jogo excessivamente a sério.

Assim, vale a pena atentarmos para as considerações a respeito da maneira como o jogo pode ser um evento capaz de proporcionar condições à expressão controlada de antagonismos. Porém, esta possibilidade acaba entrando em colapso, caso a excessiva hostilidade inviabilize a expressão deste mesmo antagonismo.

[...] o choque entre times de futebol no campo, pode prover os significados pelos quais o antagonismo entre os dois grupos representados pelos times podem adquirir condições de encontrar-se de maneira controlada e lhes dar expressão. Nós podemos então, prever que, pelo menos, tanto quanto espectadores estiverem preocupados, dois times emergentes do mesmo grupo social podem produzir um conflito que ficará vazio e dois times emergentes de grupos abertamente opostos um ao outro podem provocar incidentes durantes os quais tanta hostilidade flui para dentro da atividade mútua do encontro esportivo até romper a membrana ao seu redor, levando a revoltas, brigas e outros sinais de quebra na ordem. Isto tudo foi sugerido por Max Gluckman em sua discussão do futebol inglês, onde procurou explicar porque as ligas de times podem representar escolas diferentes, cidades e regiões, mas com muito mais dificuldade diferentes grupos religiosos e diferentes classes sociais [...]. (GOFFMAN; MCGINNIS, 1961, p. 71-72, tradução nossa)

Foi preciso um elemento ambíguo, como um goleiro "vapor”, para dar vazão à oposição estrutural entre funcionários 
e acolhidos; entre usuários de drogas declarados e orientadores socioeducativos. No cotidiano dos Centros de Acolhida e de Convivência ocorrem desavenças e conflitos de interesses variados, motivados muitas vezes pela escassez de recursos como vaga para pernoite, ou por regras duras como a proibição de fumar dentro ou nas imediações do equipamento, sob pena de perda da vaga. Regras estas impostas por gestores muitas vezes guiados por suas convicções religiosas, considerando que parte significativa destes equipamentos é gerida por entidades confessionais. Isto faz surgir e perpetua rivalidades entre os membros do quadro de funcionários, principalmente os orientadores socioeducativos, e os acolhidos. Neste sentido, a distância simbólica entre a partida, o campeonato e a opressão diária presente nas interações no interior do Centro de Acolhida não pôde mais ser assegurada quando o incidente rompeu a membrana responsável por controlar o fluxo, para dentro do jogo, de sentimentos de animosidade relevantes externamente.

As regras de transformação permitem a interação em virtude de um disfarce possibilitado pelo jogo. Estas regras são assim definidas pelos autores de Fun in games:

A barreira a bens externamente atribuídos se assemelha mais a um biombo do que a uma parede sólida e, além disso, também transforma e modifica o que passa através dela. Falando mais estritamente, pode-se pensar em regras inibitórias que dizem aos participantes ao que eles não devem prestar atenção e de regras de facilitação que lhes dizem o que podem reconhecer [...] A estas regras de ser, ambas inibitórias e facilitadoras, que nos dizem qual modificação na forma irá ocorrer quando a um padrão externo de bens, é dada expressão dentro do encontro. (GOFFMAN; MCGINNIS, 1961, p. 67, tradução nossa)

Os diferentes papéis, externos e internos ao jogo, podem ter sua introdução pela membrana simbólica a envolver a partida facilitada ou inibida: de orientador socioeducativo para jogador, de acolhido para atacante, de "vapor" para goleiro e de convi- 
vente para torcedor, qualquer que seja o encontro focado, uma partida ou uma roda de crack, ${ }^{148}$ há esse tema dual. O mundo mais amplo precisa ser introduzido, mas de maneira controlada e disfarçada. Um incidente dá margem à quebra da barreira em torno do encontro e há uma inundação do que deveria ser considerado irrelevante ou ao menos, introduzido de modo contido. Indivíduos podem lidar uns com os outros, face a face, porque estão dispostos a respeitar as regras de irrelevância, a deixar fora da interação temas dificeis como as rivalidades pessoais. Dados os perigos da expressão das rivalidades, um disfarce de goleiro ou jogador pode funcionar não tanto como uma maneira de conciliar algo, mas como um caminho para revelar o nivel de competitividade que pode ser tolerado em um jogo. Os encontros são cercados dentro de portões; os próprios meios pelos quais se mantém afastada parte da realidade podem ser os meios pelos quais se pode suportar introduzi-la.

As barreiras impostas pelo enquadramento podem ser por nós apreendidas em seu dinamismo, no uso pelo professor, para melhor se comunicar com seus jogadores, de certas expressões da rua adaptadas pelas regras de transformação à realidade enquadrada do jogo. Assim, ao lado da quadra um jogador pergunta ao professor: "Tem camisa?". Ao que o professor responde: "Tá tendo, tá tendo." Típica maneira de se expressar na rua, onde não se pergunta se alguém tem água, por exemplo, mas se "tá tendo" água. Da mesma forma, mandar um salve a um jogador: "Cadê o Roberto? Salve Roberto!", ou o uso de termos como irmão e primo, associados ao crime organizado como vimos acima: "Joga com essa (camisa) mesmo, José”. Como José não responde: “Joga com essa mesmo, primo". Ainda, outros termos comuns na rua: "Volta, volta, cai pra grupo não [...], calma 'parça' [...], valeu família".O uso destes termos não parece enfraquecer a barreira necessária ao enqua-

$148 \mathrm{Na}$ roda de crack aquilo que deveria permanecer fora da interação e nela adentra, de modo prejudicial, é chamado de "radiação". 
dramento do jogo, mas aparentemente, o torna mais próximo dos jogadores, principalmente se eventualmente, o comparamos com o distanciamento de um treinamento simplesmente baseado nos princípios da educação física.

O fato do campeonato não se restringir apenas a funcionários, ou acolhidos e conviventes é uma maneira de ampliar as fronteiras do encontro e potencialmente confirma e consolida sentimentos relevantes oriundos de outro local. No caso de Ronaldo e o orientador socioeducativo com quem se desentendeu no jogo, a desavença tinha origem anterior e foi renovada nas partidas.

Para Goffman e McGinnes (1961), as racionalizações mais comuns sobre as causas da endogamia social, a regra pela qual apenas iguais são convidados a um encontro social, remetem ao receio de que a mistura de diferentes classes de pessoas faria todos os participantes do encontro focado se sentirem desconfortáveis. Mas devemos atentar também para uma preocupação oposta a esta. Geralmente, conversações e jogos falham não porque os participantes são insuficientemente próximos socialmente, mas porque não são suficientemente distantes. Nos treinos, a absorção pelas partidas costuma ser uma fração do campeonato com mescla de times de categorias distintas de pessoas no sistema de acolhimento. Aquilo que os autores acima denominam como "função de euforia para uma ocasião social” (GOFFMAN; MCGINNIS, 1961, p. 79) reside em algum lugar situado entre a pequena e a grande diferença social, como são as diferenças entre acolhidos e funcionários. No encontro focado absorvente, uma dissolução de certa distância social externamente baseada precisa ser alcançada, com uma penetração das fronteiras do ego. Porém, esta dissolução não necessita ser tão extensa que torne os participantes receosos, ameaçados, ou autoconscientemente preocupados com o que está acontecendo socialmente. Ganhos ou perdas potencialmente muito elevados precisam ser evitados, assim como a possibili- 
dade de haver apenas ganhos ou perdas pouco significativos. Ronaldo tinha muito a perder ao ser confrontado como um mero acolhido, sendo ele "vapor", parente de um "irmão" e não dormir em albergue. Além disto, como mais uma limitação ao enquadramento das partidas e a imposição de barreiras para a realidade externa ao encontro focado, Ronaldo, com apenas 21 anos de idade, tinha sua namorada (desde os 15 anos de idade) participando como torcedora.

\section{A manipulação das regras do jogo}

Nas partidas de futebol do Intertendas ocorre a dramatização dos dilemas da vida de usuários de crack e funcionários das instituições que os abrigam e entretém. Mesmo voltando às antigas condições de "população de rua", uma certeza permanecerá entre os acolhidos: "eles podem vencer no futebol". Porém, obter a vitória pode ter condicionantes para além da qualidade dos times. Na descrição dos membros da sociedade de esquina, mais especificamente do boliche entre os Nortons, feita por Whyte, tomamos conhecimento da variedade de pressões sociais que os jogadores introduzem uns sobre os outros. Estas pressões têm por efeito aproximar o posicionamento relativo das habilidades dos jogadores e seu posicionamento na hierarquia social da panelinha dos amigos de esquina. (WHYTE, 2005) Algo semelhante ocorre no "baba", o futebol praticado nas praias de Salvador e estudado por Jeferson Bacelar (1991). Um time proveniente das áreas de classe média do bairro pesquisado, caso se aventuresse a jogar nas quadras frequentadas após dura conquista, pelos estratos mais proletarizados sairia invariavelmente derrotado do campo, em decorrência das manipulações das regras do jogo e até a violência física exercida pelos líderes do pedaço.

Vimos como as regras do jogo são capazes de influir no sentido de seu enquadramento e passam a governar a execussão dos movimentos no interior de uma situação de jogo. Também 
observamos a necessidade de novos acordos sucessivos sobre elas, após todos os jogadores de dois times empatados terem batido seus pênaltis sem sucesso na tentativa de desempate. Ao persistir a igualdade no resultado, o goleiro Ronaldo chegou até a bater pênaltis seguidos. Em parte dos jogos de treino por nós observados, mais dedicados à diversão e não a preparação para a participação em campeonatos, ${ }^{149}$ a ausência de um juiz permitia aos próprios jogadores manipular as regras do jogo.

Goffman e McGinnes (1961) mencionam a descrição da "pura sociabilidade" feita por Simmel, para situar o advento moderno da universalidade das regras: "Riqueza, posição social, erudição, fama, capacidades excepcionais e méritos, não devem tomar nenhuma parte na sociabilidade". (SIMMEL, 1950 , p. 45-46) Também dizem respeito às regras, as considerações weberianas sobre o capitalismo e seu modo de transcorrer "sem considerar as pessoas", o lema do mercado, assim como, na moderna burocracia, o primado da "igualdade perante a lei". (WEBER, 1946, p. 215-216) Ou, no caso do futebol, perante a regra.

Estas ideias a respeito da universalidade das regras presentes no futebol são mencionadas por Roberto DaMatta ao procurar traçar um paralelo entre o "corpo universal" (DAMATTA, 2006) da modernidade e, recorrendo a Gilberto Freyre, os corpos tradicionais de senhores e escravos, estes, ativos e fortes, enquanto aqueles seriam sedentários. O futebol traria a ideia de um corpo desejado por todos, independente de posição social. Segundo este autor, a sociedade brasileira na época da chegada do futebol no país, na virada do século XIX para o século XX, discutia a ideologia liberal da meritocracia e o futebol seria um esporte meritocrático, por meio do qual um corpo talentoso e capaz de alto desempenho nos campos seria capaz de proporcionar mobilidade social a alguém. Parece que o autor

149 Certa vez na saída de um treino ouvi o seguinte comentário: "É campeonato? É só pra brincar, se divertir". 
prefere não levar em conta o fato de o futebol ter sido profissionalizado no país, apenas em meados dos anos 1930, nem de o destino dos jogadores oriundos da classe trabalhadora, mesmo para aqueles com sucesso dentro de campo, fosse retornar à miséria de onde vieram e, não poucas vezes, em condições ainda piores que seus pares trabalhadores e isto, até poucas décadas atrás. ${ }^{150}$ Mesmo assim, futebol teria sido nosso "mais contundente professor de democracia e igualdade" (DAMATTA, 2006, p. 142) por afirmar os valores capitalistas básicos. Ainda segundo este autor, o individualismo e o igualitarismo presentes na prática futebolística, também viriam ao auxílio da "socialização de uma justiça burguesa e universalista”. (DAMATTA, 2006 , p. 150) O individualismo estaria contido na possibilidade, entre outras, de todos poderem se tornar atletas, embora, esqueça o autor o fato dos jogadores profissionais estarem desde os primórdios do profissionalismo, presos aos clubes como o servos à terra (GALEANO, 1995) por contratos vitalícios, apenas podendo eles, se deslocarem de equipe, com a anuência do time dono de seu passe. ${ }^{151} \mathrm{O}$ próprio Roberto DaMatta reconhece a dificuldade dos imperativos liberais descerem à terra e afirma que "a regra impessoal e igualitária opera até o ponto de não ameaçar os privilégios como outras sociedades com forte ranço tradicional, (com destaque nas relações pessoais, verticalizadas e hierárquicas)". (DAMATTA, 1982, p. 35)

Seria talvez mais cuidadoso se ficássemos com as ideias de Richard Sennet sobre a relação entre regras e igualdade nos esportes: “Jogar requer uma libertação de si mesmo, mas essa liberdade só pode ser criada por meio de regras que estabelece-

150 Citando o autor, "Pois eram disponibilidades que destronavam velhas expectativas, indicando que era o trabalho e o que vinha com ele que iria determinar o lugar de cada indivíduo no sistema". (DAMATTA, 2006, p. 138) O que seria a sociedade escravocrata se não a confirmação desta frase?

151 Esta justiça teria "como procedimento básico a confiança de que tais normas serão aplicadas com isenção por pessoas capazes de controlar seus interesses e simpatias pessoais". (DAMATTA, 2006, p. 150) 
rão uma ficção de igualdade inicial de poder entre os jogadores". (SENNET, 1988, p. 389, grifo nosso) Se olharmos mais atentamente, dentro de campo, nenhum jogador é igual ao outro. Seja em habilidade, em posicionamento, ou em temperamento. Sejam nas suas obrigações decorrentes da posição. Um ala não tem a mesma obrigação de defender o time dos ataques alheios que um pivô, mais sujeito a cometer faltas e ser penalizado ou vitimado pelas regras. O juiz, certamente entra em campo com um conceito a respeito dos jogadores com quem lidará durante a partida. Um imperativo de igualdade quando desce das alturas da ideologia, aparentemente serve mais à instauração da desigualdade e menos a propósitos igualitários.

Os jogos populares de futebol em Salvador, brilhantemente descritos e analisados por Jeferson Bacelar (1991) promovem dois movimentos complementares, primeiro uma inversão da ordem estabelecida pela vitória dos times de jogadores proletarizados sobre os de classe média; e em segundo lugar, um "reforço da coesão coletiva e no exclusivismo grupal". (BACELAR, 1991, p. 110) Estes trabalhadores acostumados às derrotas diárias, têm no "baba" a possibilidade da vitória e da realização pessoal. O prestígio como jogador está não só associado ao desempenho, mas a uma performance de valentia e ao seu passado no bairro. Como não há juiz, o prestígio possibilita a manipulação das regras e influência nos resultados e estes voltam a confirmar a importância da pessoa por uma espécie de retroalimentação. A liderança "não se faz apenas no 'baba' em si, refletindo também o estatuto dos jogadores no bairro e suas relações com a sociedade mais ampla”. (BACELAR, 1991, p. 98) Assim, o "baba" permite a passagem através da barreira em torno do jogo, de alguns privilégios e do prestígio auferido externamente. As regras de irrelevância não se aplicam a valentia provada em embates pelo bairro. Como não há técnico, são os líderes os responsáveis por montar e instruir os times; na ausência de juiz, manipulam as regras e sua capacidade de 
manipulação se encontra ligada a seu estatuto no bairro. Ainda assim, como as regras podem ser manipuladas, mas não modificadas, times de jogadores anônimos conseguem, por vezes, vencer equipes de líderes do bairro.

Vimos acima, como os jogos se constituem em oportunidades de exibição de atributos socialmente valorizados. Porém, o "baba" nos coloca outra dimensão, a do reconhecimento microssocial, nele há a possibilidade de tornar-se centro das atenções, insubstituivel, possuidor de fama, admirado, valorizado e diferenciado no "pedaço". Ou, em nosso caso, na rua, entre os conviventes na Tenda e entre os acolhidos no Centro de Acolhida. Ao se consagrar campeã, a equipe de Ronaldo e Maradona, teve suas fotos com a taça expostas em um mural no centro da Tenda por eles frequentado. Houve reportagem publicada no site da Smads $^{152}$ e semanas depois, uma equipe de reportagem de um programa de esportes, veiculado nacionalmente, foi à Tenda e ao treino, entrevistando o professor e Maradona, além de uma jogadora. ${ }^{153} \mathrm{~A}$ equipe de acolhidos e conviventes venceu o campeonato e certamente, as tentativas de manipulação das regras por parte dos funcionários revelam a importância para estes de evitar uma inversão hierárquica por parte dos derrotados do dia a dia. Apesar do Intertendas não permitir a entrada dos privilégios do cotidiano no enquadramento do jogo e ainda mais, por ter uma sequência de jogos inseridos em um campeonato, com juízes razoavelmente independentes. Este campeonato, porém, pela falta de edições periódicas e por dispor na quadra jogadores inseridos em uma estrutura formalmente hierarquizada, não possui regras de transformação suficientemente elaboradas para permitir a entrada de certos atributos hierárquicos externos. Esta falta de elaboração pode ter levado ao incidente e ao colapso do enquadramento.

152 http: / / www.prefeitura.sp.gov.br/cidade/secretarias/esportes / noticias $/ ? \mathrm{p}=159695$.

153 http:/ / bandnewstv. band.uol.com.br/videos /?v=14831372. 


\section{Os pósjogos}

Ao término das partidas em um treino, o enquadramento relaxa progressivamente e os temas referentes aos jogos vão lentamente arrefecendo e abrindo espaço para outros assuntos. O corpo se encontra em outro estado, após uma série de jogos. A absorção pelo futebol afastou a rotina e estabeleceu seu próprio espaço e tempo. O pós-jogo é momento de relaxamento muscular. Quando em um treino rotineiro, os jogadores se deixam prostrar no chão e podem dividir um cigarro, ou mesmo um baseado, mas também se espera do professor uma espécie de prêmio pelo esforço do grupo em forma de garrafas de refrigerantes e pacotes de bolachas. Enquanto os jogadores estão sentados no chão bebendo e comendo, invariavelmente ele pergunta: "Alguém precisa de alguma coisa?". O sucesso da oficina de futebol em enviar e acompanhar usuários de crack a cursos e novos empregos ${ }^{154}$ está intimamente vinculado ao pós-jogo.

Os jogadores geralmente são recrutados na Tenda e levados até o local do treino, além disto, o professor passa pela Cracolândia quase diariamente e quase sempre encontra algum de seus jogadores e ex-jogadores por lá. É a oportunidade de insistir na volta às oficinas de futebol e lembrar algum "corre" a ser feito em prol do usuário, como buscar seus documentos, matricular em algum curso, entrevista de emprego ou conseguir vaga em albergue e, é claro, lembrar a data do próximo treino. Não existe falta de vagas nos cursos e o mercado de trabalho paulistano, em 2014, absorvia todos os encaminhados; a diferença está no salário e tipo de emprego. Para serviços operacionais menos remunerados, com proventos beirando o

154 Foram cerca de 90 jogadores com seus documentos providenciados e 45 enviados a cursos e vagas de empregos. Isto, somente pelo orientador socioeducativo por nós acompanhado nesta pesquisa. Um ex-jogador chegou a aparecer na propaganda politica do Partido dos Trabalhadores como exemplo de ex-aluno do Pronatec, empregado. Disponivel em: http://www. youtube.com/watch?v=L9nJ6EdJaQg. 
salário mínimo paulista, há vagas para todos os alfabetizados. Empregos mais complexos como mecânico, por exemplo, um curso como os oferecidos pelo Pronatec se faz necessário. Isto não significa, de modo algum, que não existam dificuldades, como, por exemplo, superar os sentimentos de vergonha advindos da carência, vivida por muitos alunos, de vestimenta apropriada para se apresentar em sala de aula. ${ }^{155}$ Será no pós-jogo que o professor irá se informar sobre essas demandas. Pode acontecer também de alguém que "bateu a nave" e faltou a algumas aulas precisar ser demovido da ideia de abandonar o curso, ou emprego.

Neste último caso, os problemas se revelam maiores, dado o despreparo dos departamentos de recursos humanos das empresas demandantes de mão de obra das Tendas em lidar com funcionários usuários de drogas. Como é muito usual "bater a nave" ao receber o primeiro salário, os funcionários são demitidos dentro do período de experiência no emprego, retornando à condição de desempregados, porém, em piores condições devido ao fracasso laboral.

Estes assuntos são tratados com cuidado pelo professor e ele tem essa possibilidade pela proximidade cotidiana e vínculo pessoal estabelecido através das oficinas de futebol. Muitas vezes, o processo se inicia na decisão do participante em retirar seus documentos. A resposta é imediata. De posse de um telefone celular com câmera, o professor procura a primeira parede branca e tira a foto necessária à confecção da carteira de identidade. Caso isso fosse feito na Tenda, demoraria dias ou semanas até se disporem a executar o gasto da foto e revelação. A resposta imediata se mostra fundamental e parte disto é custeada pelo professor e a outra pela Tenda. O trabalho é por

155 Aqueles em situação de rua têm muitas vezes na Tenda, sua porta de entrada para o sistema de acolhimento. Mas, isto não significa, de modo algum, disponibilidade para entrar no prédio de uma universidade e cursar o Pronatec. 
ele executado fora do horário das oficinas, isto é possivel graças a um contrato laboral que lhe dispõe certo número de horas remuneradas para este tipo de atividade. Este comprometimento pode estar ligado ao fato dele ser ex-usuário de crack na região, ex-acolhido e ex-convivente.

As oficinas de futebol possuem data fixa, no entanto, o professor tem contato com os jogadores durante ao menos, 4 dos 5 dias úteis e nos finais de semana com campeonato ou outras atividades. Por outras atividades chamamos os passeios com treino em locais comumente não frequentados pelos jogadores, como as quadras do Parque do Ibirapuera e visitas a estádios de futebol, por exemplo. Estes contatos se dão na Tenda, na Cracolândia e nas ruas do Bairro da Barra Funda e Bom Retiro, principalmente. O processo de recrutamento de novos participantes acontece nestes locais e é por convite informal. Não é necessário nenhum tipo de inscrição ou compromisso com a assiduidade na oficina. Apenas em caso de campeonatos, os jogadores que poderão entrar em campo serão os presentes nos treinos específicos para a disputa.

Os participantes não são obrigados a cessar o uso de drogas antes dos treinos. Houve um caso interessante de atraso no transporte da Tenda para a quadra e os "meninos" permaneceram por algumas horas cheirando solvente Thinner até a chegada do transporte. ${ }^{156}$

Após se saber quem são os jogadores daquela tarde, todos passam a aguardar o transporte do lado de fora da Tenda. A agitação costumava ser grande, havia muita ansiedade para jogar bola. O uniforme esportivo, camisas do time e chuteiras são trazidos de casa, geralmente a pé, pelo professor após ter ele mesmo os ter lavado. Todos na Kombi, saem em velocidade acelerada ao som invariável de músicas de rap com temática

156 O professor se viu em uma situação delicada pelo atraso da Kombi. Misturado à vontade de jogar agregava-se a possibilidade de não poder mais usar a quadra devido ao estado dos participantes. 
baseada na vida de rua, consumo de crack e problemas com a polícia como a música Mágico de $\mathrm{Oz}$ do grupo Racionais MC. ${ }^{157}$ O volume é alto, as curvas são feitas com muita velocidade, principalmente, se tratando de uma Kombi e a conversa flui quase aos gritos. No retorno, após o jogo, a mesma rotina excetuando a parada para consumo de refrigerantes e bolachas. Um ex-jogador da oficina, que iremos chamar de Ronaldo, fez parte de matéria jornalística da Rede Bandeirantes e nesta matéria, ele menciona o pós-jogo.

O crack virou almoço, virou janta, virou café da manhã, virou sobremesa. Virou namorada, virou família, virou tudo [...] Pode parecer até loucura o que vou te falar, meu. Eu olhava assim, pegava a droga. Eu já não tinha nem como mais respirar. Eu falando com você aqui, tava [sic] saindo aquele monte de fumaça do que eu já tinha fumado. Eu fumava a droga e chorando. Quantas vezes eu já fumei droga, colocando ela na boca e chorando. Que eu queria largar ela, mas ela não largava [...]. (CILLO, 2014)

Especificamente sobre as oficinas de futebol, Ronaldo descreve o processo de convite e convencimento.

Então, ele pegou e falou: 'Aí, negão, você não quer jogar uma bola com nós'. Eu falei: 'Ah, vamos lá'. Eu e o pessoal: ele paga um refrigerante, tá e tudo. Para a gente não tinha refrigerante, o nosso dinheiro era droga, droga, droga, droga. Aí eu fui uma vez, fui a segunda e depois o meu tênis estourou, porque só tinha um tênis. Morador de rua vai ter o quê? Só tinha um tênis, aí não fui mais ao futebol. Aí ele olhou pra mim e falou: 'Ô negão, você precisa ocupar seu tempo, não quer jogar bola com nós mais, porque você não faz um curso? Quer ser chefe de almoxarifado? Acho que tem vaga de chefe de almoxarifado, você quer fazer esse curso?' Eu falei: 'Quero, vamos lá'. Aî, quando eu cheguei não tinha, né. Aî, tinha o de ci-

157 Letra do grupo Racionais MC - presença constante nos trajetos entre Tenda e quadra. 
clo de motores a diesel. Aí, foi o que eu [...] me inscreveu, a última vaga. (CILLO, 2014)

O vídeo mostra na sequência, o relato do contratante sobre a iniciativa d e Ronaldo, ex-jogador na oficina de futebol e aluno do Pronatec, em pedir uma vaga de emprego para quando terminasse seu curso. Ao falar sobre seu processo de contratação, o contratado expõe sua visão do significado do novo trabalho para ele: "Quando a gente vê um homem dando uma oportunidade a uma pessoa que também quer ser um homem, assim de verdade, na sociedade, no mercado de trabalho. Tenho seu Milton como um pai, um avô, assim, uma pessoa assim [...] esse é um começo [...] sem fim”. (CILLO, 2014)

O relato acima foi exibido em rede nacional por mais de uma oportunidade e é importante por vários motivos. Primeiro, confirma a importância do ritual do pós-jogo. Geralmente, o pós-jogo consiste da devolução dos uniformes e troca de roupa, saída para a rua e entrada na Kombi com música de temática próxima à realidade fora das quadras, em alto volume. Em seguida, uma parada para o professor comprar refrigerantes e biscoitos, às vezes são fornecidos pela Tenda, mas é raro. O professor retorna ao transporte até nova parada nas proximidades do destino. Todos descem, sentam em sua maioria no chão e se inicia a distribuição dos copos, garrafas e sacos com biscoitos. Caso alguém deixe copos pelo chão, geralmente os participantes sob maior efeito de álcool, (o professor reconhece nunca ter tido problema com uso de crack, só com excesso de álcool) será chamado à atenção, muitas vezes sem sucesso. Finalmente, enquanto todos relaxam sentados, consumindo refrigerantes e bolachas, o professor pode fazer sua pergunta dedicada a iniciar ou dar continuidade ao atendimento de demandas: "Alguém precisa de alguma coisa?". 


\section{Autocontrole, o uso de crack e oficinas de futebol}

Nos jogos de futebol entre usuários de crack, álcool e outras drogas, o abuso destas, antes de uma partida, é a acusação padrão para um mau desempenho. Caso o time saiba de algum jogador que tivesse feito o uso de drogas na noite anterior a uma partida, ou tenha "batido a nave" - expressão usada para recaída no uso - este jogador será seguramente o bode expiatório, principalmente em caso de derrota. Possivelmente, sua má atuação pode até ser menos devida ao seu uso de substâncias psicoativas, ou a uma noite não dormida do que à pressão do grupo condenando seu comportamento. O jogador assíduo aos treinos e cumpridor do resguardo de drogas na véspera, não será reprimido pelas mesmas críticas feitas ao jogador displicente. Cheguei a presenciar acusações enérgicas após uma derrota em um campeonato, contra um jogador, como por exemplo: "Não vem treinar é isso, é isso. É isso que dá não vir treinar." Mais ainda, por parte do goleiro da equipe:

O cara não tem responsabilidade nenhuma, sai de 'rolê' e bate a nave, não quer saber de porra nenhuma de jogo. Ah, vai tomar no cu. Tem que ter responsabilidade. Tem que ganhar rapaz. Sai de sábado pra domingo. ${ }^{158} \mathrm{Tem}$ que ser homem, caralho! Vai bater a nave dia de semana, cara. Eu perco meu aniversário para perder por causa desse 'nóia' do caralho. Ele é meu camarada, tem que falar na cara dele, eu sou homem, entendeu?

Vimos como o envolvimento espontâneo compartilhado em uma atividade mútua coloca os parceiros em algum tipo de solidariedade exclusiva e permite a eles expressar companheirismo, proximidade psíquica e respeito mútuo. A falha em participar de boa vontade pode, em consequência, expressar rejeição aos presentes ou ao contexto. Isto, nos remete à maneira como os encontros focados conseguem prover a base de

158 A partida foi disputada em um domingo pela manhã. 
comunicação para o fluxo de sentimentos entre os participantes e proporcionar a eles compensações corretivas para atos desviantes. (GOFFMAN; MCGINNIS, 1961) As acusações sobre uso de drogas foram feitas durante todos os momentos dificeis da partida, a cada insucesso elas retornavam mais fortes, minando visivelmente a autoconfiança do acusado e acirrando ainda mais os ânimos dos outros jogadores contra ele. O mau desempenho parecia confirmar as expectativas dos demais jogadores sobre como o consumo de drogas prejudica a atuação em campo, contribuindo para reforçar ainda mais as críticas sobre ele. A própria relação tática se modificava e o jogador acusado era agora um desqualificado (GOFFMAN, 1975) dentro de campo, pouco merecedor de receber passes dos demais e assim, diminuindo as chances de ter sua atuação reconhecida pela execussão de boas jogadas e marcação de gols. Se para Whyte (2005), em seu clássico estudo sobre os garotos italianos imigrantes nos EUA do começo do século XX, existe uma correspondência entre a posição da pessoa no grupo, fora das quadras de boliche, e o desempenho dentro delas proporcionado pela pressão do grupo. Pudemos observar uma simetria entre o resguardo de drogas antes das partidas e o desempenho dentro de quadra, porém, este desempenho nos pareceu tão fortemente influenciado pela pressão da equipe de jogadores, quanto o foi na descrição e análise de Whyte.

Vimos acima, como, não obstante o envolvimento de outras pessoas no jogo, a percepção de que algum participante não está espontaneamente envolvido na atividade mútua pode levar a descrédito da identidade imputada a ele como alguém capaz e pronto para imergir-se em um encontro. Pode também enfraquecer para os outros, a confiança em seu envolvimento e sua própria crença na realidade do mundo prescrito.

Ao observar um "baba" jogado em Salvador, Jeferson Bacelar relata um incidente em que uma liderança também usa o consumo de maconha como motivo de acusação, ao discutir 
o desempenho de um jogador durante uma partida: "É melhor você ficar calado, fumando suas 'coisas' prá eu não lhe dar uns murros”. (BACELAR, 1991, p. 100) Semelhante acusação está presente na etnografia de Villela sobre uma "pelada" fluminense, quanto ao uso de maconha e cocaina, porém, o uso da primeira pôde também ser associado ao bom desempenho em campo. $\mathrm{O}$ uso de "brizola" como era chamado o "pó" na época da pesquisa, é motivo para as "zombarias mais pesadas", em tom moralista de acusação sobre seu uso continuado. A maconha, no caso de melhora incomum na atuação em uma partida, ou mesmo em uma jogada é, como dissemos acima, positivamente agregada a este sucesso: “essa é da boa!". (VILLELA, 1997, p. 73)

Para além das acusações quanto ao uso de álcool ou/e drogas, os treinamentos técnicos e táticos semanais promovidos pela oficina de futebol oferecida pela Tenda podem ser vistos como:

[...] esforços para aprimorar a comunicação expressiva corporal entre jogadores. O chamado entrosamento é um ordenamento dos enunciados do corpo, no qual os movimentos são 'sintonizados' a fim de encontrar uma conexão espaço-temporal satisfatória. A interconexão das performances dos jogadores produz uma 'orquestração' do movimento em que a bola faz transitar os 'interlocutores'. (CAVALCANTE, 2011, p. 24-25)

O jogo instala um enquadramento através de regras de irrelevância e transformação capazes de estabelecer uma barreira permeável com o mundo externo. Este enquadramento permite a absorção dos participantes, jogadores ou torcedores nos eventos da partida. Agora, devemos nos perguntar no que consiste esta absorção. Quais são as suas características e como agem na interação dentro da partida. Podemos ver a atuação de um time como uma orquestração, no qual cada ação deve ser harmônica com as outras, com jogadores se comunicando em busca da vitória comum. A comunicação corporal durante 
uma partida de futebol depende da posse ou não da bola; o possuidor intenciona vencer a marcação do adversário, enquanto este age no sentido de quebrar a interação adversária e tomar posse da bola pela marcação. Com ela se busca isolar, impedir a comunicação e induzir a uma arriscada jogada individual, colocando frente a frente marcador e driblador. Um, procura limitar espaços, enquanto outro, pela ambiguidade dos movimentos do drible tenta burlar o adversário. (CAVALCANTE, 2011)

O futebol se massifica no Brasil, a partir dos campos das elites e da intromissão dos gandulas pobres e de jogadores proletários utilizados na ausência de número suficiente de jovens ricos dispostos a jogar. Esta primeira fase de futebol popular, após seu início elitista, pode ser entendida como o tempo do império da malandragem. (CAVALCANTE, 2011) Assim, um habitus malandro baseado na valoração da diversão, experimentação e sedução surge diferente do futebol das elites, ele é marcado por um baixo autocontrole das paixões por parte dos gandulas e vadios a observar os jogos. Enquanto o futebol de elite era caracterizado pelo modelo inglês com chutes para frente e muita correria, o malandro se diferenciava por estar imerso em um contexto periférico das cidades com frouxas redes de interdependência, pressuposto para certa irresponsabilidade e abrindo caminho para a busca da satisfação e experiência corporal. Em contextos sociais diferentes, os modelos de autocontrole também se afastam.

O modelo de autocontrole, o gabarito pelo qual são moldadas as paixões, certamente varia muito de acordo com a função e a posição do indivíduo nessa cadeia [...] variações de intensidade e estabilidade no aparelho de autocontrole que apareçam à primeira vista, muito grandes. (ELIAS, 2001)

A várzea é o lugar do vadio, do gandula, do malandro e de uma rede de sociabilidade aberta para a criatividade; nela, o malandro está à procura de diversão. Seu potencial inventivo está materializado no drible, no chute "folha seca" e no "chute 
bicicleta”. Na atualidade, o futebol amador na cidade de São Paulo ainda é conhecido como futebol de várzea. A região da Barra Funda e Bom Retiro, onde jogam nossos usuários de crack, é a mesma do nascimento de inúmeros clubes de várzea, lá presentes até nossos dias como o popular Corinthians. A rua, assim como a várzea, é lugar de experimentação e criatividade constantes entre moradores das calçadas, baixos de viadutos e os mais diversos tipos de "mocós". ${ }^{159}$

Muitos são os exemplos da criatividade dos usuários de crack nos centros urbanos, particularmente o paulistano. $\mathrm{O}$ cachimbo ou "boris" usado para o consumo do crack se origina de modificações e adaptações a partir da simples folha de alumínio, onde a pedra era queimada e a fumaça sugada com um canudo; passando para o uso da folha de alumínio sobre um copo, porém, agora, perfurada na tampa e acrescida de cinza de cigarro com intuito de evitar o derramamento da pedra derretida para dentro do copo. Desde então, não mais com uso do canudo, mas com uma abertura em uma borda da tampa do copo para permitir aspirar a fumaça. Este arranjo foi mudando até chegar a processo semelhante, porém, em copo de leite fermentado tipo Yakult, com a volta do canudo cuidadosamente introduzido na lateral, para o melhor sorvimento da fumaça. Por outra via, talvez, os usuários tenham adaptado a lata de alumínio amassada ao meio, com pequeno furo na lateral curvada para depósito da pedra sobre cinzas e sorvimento pela abertura da lata destinada a saída do liquido. Este desenvolvimento avançou para alguns cachimbos em curvas dos mais diversos tipos de canos e dos mais variados materiais como PVC e metal, com o alumínio perfurado em uma das extremidades e a outra deixada livre para sorver a fumaça. Finalmente, o cachimbo de fumar crack, aberto aos mais diversos tipos

159 Nome dado aos locais utilizados como moradia como, por exemplo, buracos embaixo de viadutos. 
de adaptações ao corpo e seus múltiplos estados de fadiga e fôlego. Ele faz uma espécie de síntese dos processos criativos anteriores, com o canudo, agora definitivamente estabelecido como "caninho", o frasco de Yakult, a lata e os canos curvados transmutados em "casinha", "fogãozinho" e "curvinha"; todos reunidos à cinza sobre alumínio perfurado.

Não nos parece coincidência ter o jogo de futebol feito tanto sucesso entre os usuários de crack e também parte da população de rua. A quadra ou campo e a rua estão abertos à experimentação, criatividade e busca por diversão. Porém, não apenas de malandragem e diversão é feito o futebol praticado nas Tendas. Aî, também há uma "contaminação disciplinar". (CAVALCANTE, 2011) O futebol com disciplina, no sentido de melhorar a eficiência do jogador e da equipe em jogos de projeção midiática, pelo adestramento do corpo e ordenamento do espaço com atenção para a distribuição dos jogadores em campo, seu posicionamento e ajustamento para máximo rendimento dos movimentos e gestos por meio de atividades codificadas em táticas. (FOUCAULT, 1997) Acabou por transformar o lugar da experiência, marca do futebol malandro, no da tática, como expresso na frase: "Vamos fazer o que o professor pediu para sairmos com a vitória!”. (CAVALCANTE, 2011) A tática visa criar conectividade entre os espaços individuais incorporados a cada jogador pelo treinamento de suas características físicas, técnicas, táticas e psicológicas. ${ }^{160}$ Enfim, uma nova consciência

160 O exemplo abaixo mostra as características a serem desenvolvidas em um Ala no futebol de salão: "Função das Alas: São responsáveis pela armação das jogadas. Devem deslocar-se constantemente, com ou sem bola. $\hat{\mathrm{E}}$ importante ter na equipe sempre um jogador destro e um canhoto em cada ala. Normalmente os alas jogam em posições invertidas (ala direito no lado esquerdo e ala esquerda no lado direito). Os alas devem ser jogadores que utilizam bem os espaços vazios da quadra, com grande percepção das jogadas e precisão nos passes. Devem saber marcar e atacar na mesma proporção, ter excelente controle de bola, dribles e boa finalização são características importantes para os alas. Características físicas: altura ideal de 1,65 à 1,75. Os alas devem ter: agilidade, resistência aeróbia e anaeróbia, coordenação, força e velocidade; Características técnicas: drib- 
para tomada de decisões corretas, identificação de problemas e seleção de habilidades para resolvê-los, ao mesmo tempo em que se cria e nega espaços. (NETO; LEITE, 2010) A consciência desta interdependência gerada pela divisão de funções na quadra suscita o rebaixamento moral da diversão, deixada de lado em nome da equipe interdependente, por dispositivos incorporados para maior autocontrole dos impulsos. Soma-se a isto, o fato de que a medida em que a oficina de futebol passa a ser um treino destinado à participação em campeonatos e, posteriormente, ao campeonato propriamente dito, passa-se de situações sem autoridade central, sem juiz, contando apenas com algumas intervenções do professor, para a monopolização da organização das equipes pelo professor/técnico e pelo também monopólio das decisões quanto à interpretação das regras, concentrado no juiz.

É precisamente a formação dos monopólios que permite a instalação de um mecanismo de 'condicionamento social' graças ao qual cada indivíduo é educado no sentido de um poderoso autocontrole. Aí está a origem do mecanismo de autocontrole individual permanente cujo funcionamento é em parte automático. (ELIAS, 2007, p. 193-4, grifo nosso)

Para além da coerção social, o autocontrole seria uma transformação da economia psíquica pela interiorização das proibições, no sentido de se refrearem os impulsos espontâneos e movimentos imediatos. Segundo Elias, novas relações sociais são capazes de suscitar mudanças nos controles pulsionais no decorrer de transformações específicas nas inter-relações humanas. (ELIAS, 2007) O jogo impõe normas e valores cujos preceitos são obrigatórios para os indivíduos, a não ser pela de-

le, passe, deslocamentos, condução, chute e marcação; Características táticas: armação das jogadas, coberturas, atacar e defender, boa finalização, criatividade e visão de jogo; Características pscicológicas: coragem, combatividade, controle emocional, agressividade, determinação e iniciativa". Disponivel em: <http://pedrocostafutsal.tripod.com/futsal/id27.html>. Acesso em: 14 fev. 2014. 
sistência em participar da equipe, mas como vimos acima, os jogadores que observamos querem jogar e vencer. A racionalidade do jogo se impõe paralelamente a determinadas coerções no sentido do autocontrole das emoções e movimentos. Em um campeonato "de rua", realizado no ano seguinte ao Intertendas, a equipe adversária proveniente de outra Tenda conhecida como Complexo Prates teve um jogador reserva expulso nos instantes iniciais da partida por perguntar ao juiz se ele estaria "chupando o apito" ao não marcar uma pretensa falta em favor de seu time. Enquanto isto, pela outra equipe, o professor advertia para ninguém desrespeitar o juiz. Porém, essa recomendação foi feita mais devido a terem testemunhado a expulsão e menos pela real disposição dos jogadores de sua equipe em ofender o juiz. Como se a coerção externa tivesse sido apropriadamente transformada em coerção interna, em uma racionalidade entendida como modelo conceitual duradouro "da realidade observável nos comportamentos individuais”. (ELIAS, 2001, p. 120)

Um jogador expulso prejudica seu time, posteriormente a expulsão descrita acima, outro jogador da mesma equipe seria expulso por cometer falta grave e seu time terminou a partida com uma derrota por cinco gols a dois. É toda uma rígida rede de interdependência a exigir um autocontrole rigoroso como meio de evitar a ação impulsiva. Esta seguiria a pressão das emoções externas ao jogador, mas internas ao jogo levando a equipe ao fracasso. O jogo de futebol é um enfrentamento entre equipes submetidas à mesma regra e com um juiz responsável por interpretá-la a cada jogada e distribuir as punições. Nele, a luta aberta entre jogadores está fora das possibilidades permitidas pelas regras adotadas e tanto quanto existe uma barreira a enquadrar o jogo e a defendê-lo das influências externas irá se desenvolver através dos treinos e jogos em campeonatos, uma couraça protetora no jogador contra o extravasamento de certas emoções. Esta couraça mantém as emoções sem vazão para o mundo externo e também retém este mundo fora do sujeito. Assim, abre a possibilidade da elevação de "um muro real 
interpondo-se entre eles mesmos e os objetos de sua reflexão". (ELIAS, 2001, p. 279) O futebol abre espaço momentâneo para se separar do mundo e o autocontrole ${ }^{161}$ do jogador inserido na tática da equipe ajuda no soerguimento da couraça necessária à reflexão sobre a realidade externa.

Para compreendermos a extensão das consequências deste envolvimento no jogo se faz necessário revisitar um importante conceito para compreender as flutuações no consumo de drogas, o de estrutura de vida. (GRUND, 1993) Ela se refere a padrões regulares de atividades laborais, recreativos, domésticos e criminais que moldam e constrangem o dia a dia de usuários. São estas atividades regulares (tanto convencionais quanto as relacionadas ao uso de drogas) que estruturam os padrões diários como determinantes chaves da estrutura de vida. Parece lógico incluir os relacionamentos pessoais, compromissos, obrigações, responsabilidades, metas e expectativas. Relacionamentos que são exigentes e simultaneamente tem valor social (afetos) ou econômico (salários) são determinantes igualmente importantes para a estrutura de vida. Contatos regulares com usuários controlados e não usuários são, também de considerável importância, assim como a participação nas estruturas e atividades não motivadas (primariamente) por incentivos relacionados a drogas.

A importância da estrutura de vida é muito claramente demonstrada pela sua ausência, como representado pelo que Grund (1993) chama de junkie de rua. Este tipo de usuário se assemelha com a quase totalidade dos participantes da oficina de futebol, a condição de viver do "corre" incerto e diário, sem uma renda fixa assegurada. Assim como o junk de rua, o usuário de crack sujeito a uma mudança repentina na dispo-

161 A exigência de autocontrole também impõe moderação em face de oponentes, estes não são inimigos absolutos, em determinadas situações de tabela de jogos, o adversário de hoje pode ser a equipe por quem vá se torcer amanhã, caso ele venha enfrentar um time de quem se esteja dependente de sua derrota para obter uma melhor posição nesta tabela. 
nibilidade de drogas - mesmo que seja no sentido de torná-la mais abundante - vê perturbado ou desestabilizado seu padrão diário e estabelecido de atividades (tanto convencionais como relacionado a drogas) e pode levar a uma escalada do uso. ${ }^{162}$

No estudo de Grund (1993) sobre usuários de heroína, foi constatado o fato de um traficante bem-sucedido se vir obrigado a trabalhar sempre em horas fixas, com um time razoável de empregados e manter um registro preciso do balanço financeiro. Devido a isto, não pode, por exemplo, aparecer no ponto de venda em horas irregulares, pois esse comércio varejista para ser bem-sucedido requer estabilidade e continuidade. Tais estipulações estruturam substancialmente a alocação de tempo dos traficantes de sucesso. Assim, a forma e o grau de estrutura de vida são resultado de atividades regulares, relacionamentos, compromissos, responsabilidades e ambições que podem estar ligados ou não às drogas.

A participação nas oficinas de futebol pode ser vista em um contínuo de estrutura de vida, partindo da entrada na oficina e frequência esporádica nos treinos, culminando nas atuações em campeonatos "de rua" com treinos circunscritos à equipe. Neste trajeto, o jogador passa de frequentador ocasional a assíduo nos treinos, comprometendo-se com datas e horários e também passa a estar disponivel em horários e dias fixos na Tenda para seguir ao treino na Kombi. Posteriormente, pode ingressar em equipe participante de "campeonato de Tenda", juntamente com os jogadores ligados aos equipamentos públicos dedicados à população de rua; depois em campeonatos externos e ter contato com equipes fora deste universo. Paralelamente, segue a tirada de documentos, matrícula em cursos e admissão em um emprego remunerado com carteira assinada. A saída da rua iniciada

162 Um interlocutor nos descreveu uma situação de incremento na disponibilidade de crack devido a um "corre" muito bem-sucedido. Segundo ele, nesta ocasião teria sido convidado a fazer uso de uma "rapa", nome dado à "borra" produzida no processo de consumo da droga, proveniente da queima de 80 pedras. 
pelo frequentar da Tenda prossegue com a ida para um centro de acolhida, ou albergue e posteriormente a um Hotel Social ${ }^{163} \mathrm{e}$ repúblicas, ${ }^{164}$ até um possivel reencontro familiar. Em paralelo, vem o maior autocontrole no uso de álcool e drogas, particularmente o crack e a inserção no mercado de trabalho. Vemos isto abaixo, de forma esquematizada:

Figura 42 - Esquema ideal de desenvolvimento da participante nas oficinas de futebol

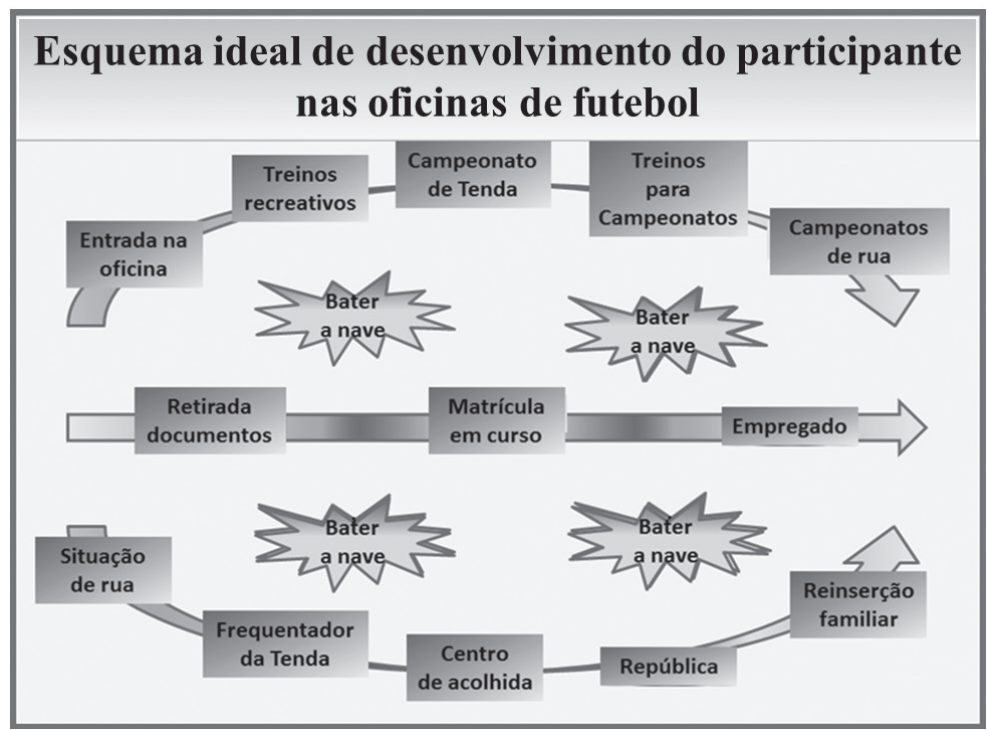

Fonte: Coleção particular do autor

163 "Esta modalidade é ofertada aos usuários independentes e socialmente ativos através de convênio vinculado com hotéis". (SECRETARIA MUNICIPAL DE ASSISTÊNCIA E DESENVOLVIMENTO SOCIAL, 2009, p. 116)

164 "Unidade de acolhida desenvolvida em sistema de cogestão, com capacidade que varia de acordo com o ciclo de vida, gênero, de forma diferenciada para cada faixa etária e diferentes segmentos, com atenção às demandas e necessidades específicas do público a que se destina. Tem como objetivo a garantia da proteção integral para o público atendido, que tenha independência para as atividades da vida diária. Tem como público idoso, pessoas com deficiência, mulheres e homens com vivência de rua". (SECRETARIA MUNICIPAL DE ASSISTÊNCIA E DESENVOLVIMENTO SOCIAL, 2009, p. 120-121) 


\section{De brigas de galos e incidentes entre homens}

As regras de irrelevância são fundamentais para tornar possivel um encontro focado com as características do jogo de futebol, particularmente quando jogado por homens dispostos em hierarquias formalmente estruturadas dentro de equipamentos públicos destinados ao atendimento da população em situação de rua. A inobservância destas regras pode provocar incidentes capazes de desobrigar os participantes a sustentar seu disfarce e a própria interação face a face enquadrada. As "rivalidades do status" (GEERTZ, 1989, p. 291) celebradas na famosa descrição sobre a briga de galos em Bali, não parecem estar disponiveis à celebração nos jogos absorventes entre homens.

Uma briga de galos absorvente, termo que Geertz tira de Fun in Games, é aquela na qual se defrontam "os mais iguais e melhores possiveis" (GEERTZ, 1989, p. 298) e, assim como no jogo entre homens, muito pode estar em questão, "o saber, a estima, a honra, a dignidade, o respeito - em suma, o status" (GEERTZ, 1989, p. 300) que pode ser afirmado ou momentaneamente insultado. Mesmo porque, no caso balinês as somas apostadas não são suficientes para alterar a hierarquia das fortunas pessoais em longo prazo. A hierarquia moral quando posta em questão torna o jogo mais absorvente, são os jogos no qual o status de alguém influente está sob ameaça, os jogos movidos a dinheiro, que não colocam nenhuma posição social em jogo, são menos absorventes. Porém, é pelo dinheiro em vultosas quantias que pode ocorrer "a migração da hierarquia de status balinesa para o corpo da briga de galos". (GEERTZ, 1989, p. 303) Na briga de galos, o prestígio pessoal pode ser reafirmado, celebrado e dramatizado. Os balineses podem brincar com o fogo "sem o risco de se queimar" (GEERTZ, 1989, p. 308) e exibir suas paixões sociais nesta caricatura de guerra, sem alterar a hierarquia. São os sentimentos sobre esta 
hierarquia que podem revelar-se nas lutas, nesta interpretação balinesa de sua própria experiência.

Os jogos por nós observados no Intertendas e campeonatos "de rua" podem desmoronar caso o status pessoal não seja devidamente contido pelas regras de irrelevância. As brigas de galos em Bali eram desfeitas pela ação da polícia, na Barra Funda, os jogos de futebol podem ruir pela ação dos participantes. Isto nos revela uma diferença entre as disputas entre homens e as disputas entre homens através de não humanos. O enquadramento dos animais não depende de seu disfarce, tão pouco de sua vontade. Para ter uma luta de galos absorvente os donos dos animais manipulam apostas em animais mais ou menos identificados com homens. Porém, os galos não podem deixar de apoiar sua interação na briga e abandoná-la, os homens sim, a aposta destes é neles mesmos.

Para concluir este capítulo é importante observar que a retomada do emprego na cidade de São Paulo deu início a um processo de proletarização do lumpesinato, nitidamente percebivel no dia a dia de quem acompanha os serviços direcionados à população de rua, com os quadros de avisos dos equipamentos públicos como Tendas e Centros de Convivência repletos de papéis anunciando vagas de trabalho. Assim como, pelos panfletos distribuídos pelas assistentes sociais com indicações de locais de contratação imediata de mão de obra e nas conversas com acolhidos, conviventes, orientadores socioeducativos e técnicos. Este fator socioeconômico é o pano de fundo estrutural, juntamente com a grande disponibilidade de acesso a cursos de formação profissionalizante gratuitos como o Pronatec, para compreender as consequências das oficinas de futebol sobre seus jogadores, na imensa maioria usuários de crack.

O jogo de futebol fornece a possibilidade de grande absorção em seu interior, pelo enquadramento gerado pelas regras 
de irrelevância. Casos como o incidente com o goleiro Ronaldo são a prova da importância dessas regras. Este envolvimento profundo permite ao professor trabalhar tecnicamente os jogadores aumentando sua interdependência, sintonia e orquestração. A vontade de jogar e de vencer leva à participação em campeonatos e a deslocamentos para realidades fora daquelas próprias ao cotidiano da rua. Ao mesmo tempo, no pós-jogo, o professor oferece uma série de serviços e indica outros rumos a serem seguidos pelos jogadores. Mas, essas aberturas de perspectiva só logram êxito com o acompanhamento do jogador pelo professor. É necessário, assim, abandonar visões ingênuas do esporte como as expressas no lema: "Esporte não é droga. Pratique". Oriundo de campanhas de prevenção ao abuso de drogas da década de 1980. O futebol em si mesmo pode exercer apenas alguma influência sobre o autocontrole do usuário de drogas sobre seu consumo. Para haver adesão às oficinas é fundamental, como declarou o professor, trabalhar na perspectiva de redução de danos onde "ninguém precisa parar de usar". Tal mudança no uso só é possivel no contexto de um ambiente socioeconômico onde o mercado de trabalho se mostra menos excludente, com uma mudança na estrutura de vida do usuário gerada pelos compromissos advindos dos ciclos de treinamentos e jogos, assim como por um acompanhamento individual pelo professor. Sem isto, o esporte pouco poderia influenciar nos padrões de uso. 


\section{CONCLUSÃO}

Antes de acessar o campo, nosso projeto original era pesquisar o uso controlado de crack entre camadas médias urbanas na cidade de São Paulo, porém, o campo nos levou em outra direção e muito além. Enquanto buscávamos contato com possiveis usuários de camadas médias, nos interessamos pelo campo da região da Luz, mais conhecido como Cracolândia. Lá fizemos nossas primeiras observações ao frequentarmos um bar em frente à Praça Júlio Prestes. Isto antes da implementação do Programa DBA, mais especificamente em fevereiro do ano de 2013. Durante esse campo, pudemos ter nosso primeiro contato físico com a pedra de crack, com o cachimbo e conversar com usuários, além de observar o uso e a repressão policial. Observamos também cenas cotidianas como a da expulsão de usuárias do estabelecimento comercial que tomei inicialmente, como ponto de observação para acompanhar os usuários do outro lado da rua, na mureta da praça. Atualmente, os usuários não frequentam mais o local; o imóvel que abrigava o bar está fechado, disponivel para aluguel e o uso ficou restrito ao espaço em frente do Programa DBA, ou em suas proximidades.

Enquanto iniciava minha pesquisa na Cracolândia, surgiu Newman e através dele fui introduzido de modo abrupto e definitivo dentro do universo de uso do crack. Ele era um usuário de classe média e atualmente deixou de usar a pedra, mas através dele pude ter contato com o uso feito por uma população de rua e estes interlocutores se revelaram de enorme ajuda à pesquisa etnográfica. Não apenas por representarem a maior parcela dos usuários das capitais (BASTOS; BERTONI, 2014), mas pela riqueza de informações concentradas em nossas visitas ao campo. Portanto, podemos dizer que seguimos o campo e as possibilidades por ele descortinadas. O mesmo pode-se dizer dos times futebol de usuários de crack e do Programa DBA. Após conhecermos o uso do crack na companhia de Newman, 
fomos deixados a sós para continuar nossa pesquisa de campo, quando ele decidiu abandonar o crack. Passamos então, a frequentar as cenas de uso sozinhos e decidimos retornar à Cracolândia, porém, agora munidos da experiência adquirida nas incursões com Newman, assim, pudemos vivenciar a transição da Cracolândia antes e após Programa DBA. No caso dos times de futebol por nós pesquisados deu-se algo semelhante. Em uma palestra por nós ministrada na Liga Acadêmica de Farmacodependência da Universidade Federal de São Paulo (UNIFESP) e nas reuniões da Associação Brasileira Multidisciplinar de Estudos Sobre Drogas (ABRAMD) Educação realizadas periodicamente na Unidade de Dependência de Drogas (UDED) da UNIFESP, entrei em contato com o orientador socioeducativo responsável pelas oficinas de futebol de um equipamento público destinado à população de rua e, após consulta com nosso orientador resolvemos estender até aí, nosso campo. Portanto, o objetivo inicial do projeto de pesquisa de doutorado, a importância do contexto social no uso do crack em camadas médias urbanas foi modificado pelas possibilidades abertas pelo campo para a importância do contexto no uso por pessoas em situação de vulnerabilidade social. Assim, as "biqueiras" com fumódromo, a Cracolândia, antes e depois do Programa DBA e os times de futebol nos apresentam diferentes contextos relacionados ao consumo do crack.

Até então, havia a crença de que o crack levasse ao isolamento progressivo do usuário até mergulhá-lo na mais deprimente das solidões, acompanhado somente de seu cachimbo e condenado à morte. Com a roda de crack vimos um quadro diferenciado e neste uso coletivo pudemos perceber as nuances antes relegadas ao desconhecimento pelos pesquisadores que tiveram pouca, ou nenhuma possibilidade de vivenciar o contexto de uso. Este contexto é rico em interações humanas fundadas nas mais diversas trocas e possui uma diversificada cultura material, também repleta de expressões próprias, de técnicas de 
construção de moradias na rua, ou, por que não dizer, de uma arquitetura singular, além de sérias preocupações quanto à reciprocidade nas trocas. Portanto, podemos afirmar que o uso do crack pode levar a uma vida repleta de sociabilidade, na qual o abandono dos bens materiais pode ser visto como vinculado tanto ao desejo de negociar no circuito da "treta", quanto ao de participar de uma "communitas" de despossuídos.

A grande questão teórica deste livro é sobre a validade da ideia de contexto social para marcar a importância das interações humanas no ambiente de uso, ou a necessidade de abandoná-la após as críticas da TAR. A resposta é não, não devemos abandonar a ideia de contexto social. Aqui, ele não foi tratado simploriamente como mero pano de fundo sobre o qual os atores agiriam, buscamos, ao contrário disto, ir além do social e trazer os não humanos e suas agências para o centro da discussão. Nisto, a TAR pode ser de grande valia aos antropólogos dispostos a enfrentar o desafio de adentrar no mundo das drogas como pesquisadores. Seria uma simplificação por demais injusta crer que trabalhos como os de Becker (2008), Zinberg (1984) e Grund (1993) não fazem mais que estabelecer um pano de fundo ao considerarem o setting de uso. O que eles fizeram foi uma busca incessante em estabelecer as conexões sociais do uso de drogas. Mais ainda. Com grande dificuldade, os pesquisadores da área de ciências sociais no país, com destaque ao orientador de minha pesquisa de doutorado, Edward MacRae, vêm nas últimas três décadas, buscando inserir no debate acadêmico e político sobre drogas, uma dimensão do problema quase totalmente relegada pelos profissionais que lidam com o tema e que vá além da ideia simplista de uma droga em contato com o corpo do usuário e de sua psique. Esses estudiosos têm lutado diariamente, para que, cada vez mais, a importância do contexto social seja levada em conta. O Programa DBA é um triunfo prático desta visão. Portanto, deixar de lado este importante aspecto do uso de drogas, ou ter de deixá-lo de lado por querelas acadêmicas, por mais 
importantes que elas nos pareçam em determinado estado das ciências sociais é uma temeridade. Como muito bem observou o próprio Bruno Latour:

Com efeito, em muitas situações, recorrer à sociologia do social é não apenas sensato, mas também indispensável, pois ela oferece uma forma prática e oportuna de designar todos os elementos já aceitos na esfera coletiva. Seria tolo e pedante evitar o uso de noções como 'IBM', 'França', 'cultura maori', 'mobilidade ascendente', 'totalitarismo', 'classe média baixa', 'contexto político', 'capital social', 'enxugamento', 'construção social', 'agente individual', 'motivações inconscientes', 'pressões do grupo' etc. (LAYOUR, 2012, p. 31)

Se for para sermos sensatos, como nos aconselha Latour, devemos levar em conta que, na situação atual do debate sobre drogas no Brasil, ainda temos muito que trabalhar para que a ideia de contexto social seja aceita por aqueles que estudam e trabalham na área das drogas. Mais ainda, caso quiséssemos condenar os trabalhos realizados a partir das pesquisas de Howard Becker, estariamos talvez incorrendo no erro de querermos ser mais realistas que o próprio rei, haja visto o relacionamento e colaboração constante entre Howard Becker e Bruno Latour. 'Howie' Becker, como carinhosamente o trata Latour nos agradecimentos de Reagregando o social foi um dos responsáveis por discutir o rascunho desta obra e perguntado em uma entrevista sobre o trabalho de Latour, Becker respondeu:

Eu pensava que ele estivesse fazendo a mesma coisa com respeito à ciência que eu havia tentado fazer com respeito à arte no livro Art Worlds. Você sabe, que o objeto científico, tal qual o objeto de arte, é uma criação de todo aquele envolvido, que teve algo a ver com ele e então há este processo como o processo que ele descreveu em Ciência em Ação, onde o destino do resultado está nas mãos das pessoas que o buscarem. Então, para mim pareceu que estávamos fazendo a mesma coisa. [...] Mas ele e eu nos tornamos good buddies. (BECKER, 2005, tradução nossa) 
Para além destas importantes questões teóricas e mesmo políticas, relacionadas às drogas, e a contribuição que a antropologia possa dar ao debate em torno do tema. Faz-se necessário fazermos aqui algumas considerações mais gerais. $\mathrm{O}$ crack, para infelicidade de seus usuários, ganhou notoriedade e tornou-se fonte de renda para empreendedores dispostos a oferecer serviços dedicados ao "tratamento". Com apoio estatal criou-se um negócio lucrativo e sem riscos, no qual o poder público envia atualmente milhares (BERGAMIM JUNIOR, 2014) de usuários para serem "tratados" e engordarem os bolsos dos donos de clínicas, um verdadeiro complexo industrial do abuso de drogas. (ZINBERG, 1984, p. 211) Isto não seria possível sem certas crenças criadas desde o início da chamada "Guerra às Drogas" no governo do presidente norte-americano Ronald Reagan. A primeira delas é a de que, com menos usuários nas ruas teremos uma menor quantidade de uso abusivo. No caso do crack, isto se dá de modo mais dramático por se desconsiderar a possibilidade de qualquer uso não abusivo da substância. Portanto, fica mais forte a ideia de que se punindo os usuários e reduzindo-se pela repressão a disponibilidade da droga combate-se uma suposta epidemia. Não se acredita, ou melhor, se desconhecem os controles sociais informais que poderiam ser fomentados e se considera que todos que usam crack são necessariamente abusadores.

Porém, iniciativas como o Programa DBA nos mostram como controles sociais formais razoáveis podem interagir perfeitamente com rituais e sanções responsáveis por estabelecer controles sociais informais, vimos algo semelhante também nas equipes de futebol. À máxima dos craqueiros "usar sem ser usado", o Programa DBA acrescentou uma série de preceitos quanto ao cumprimento de horários e comparecimento a certas atividades; isto ajuda a compor uma série de pressões no sentido de assumir certo padrão mais discreto de uso. Os controles informais passam, portanto, a atuar no sentido do pensar a respeito de 
qual droga será usada (crack ou Corote?), onde (fora da quadra e do trecho do Programa DBA?); Quando (antes ou depois do jogo ou do trabalho?); Como (ingerindo álcool a partir de uma garrafa PET ou fumando na lata?); e com quem (sem os colegas de trecho e equipe de futebol ou com eles?). Questões estas, críticas para o desenvolvimento de controles informais.

Estes controles informais podem ser considerados em sua relação com os controles formais, não especificamente sobre o uso, mas presentes no cotidiano estruturado. Vemos abaixo, uma ilustração das diferenças entre a "communitas" dos usuários de crack e a estrutura proporcionada pelo Programa DBA e pelos times de futebol. A primeira, a "communitas", marcada pelas tentações da liberdade e igualdade. Já os contextos estruturados, próprios das pessoas sociais, são marcados pela hierarquia e submissão à autoridade formal. O desafio está em fazer da promessa de futuro e dos novos vínculos, algo tão ou mais atraente que a satisfação imediata e as conexões disponíveis no "fluxo".

Figura 43 - "Communitas" e Estrutura como contextos diferenciados

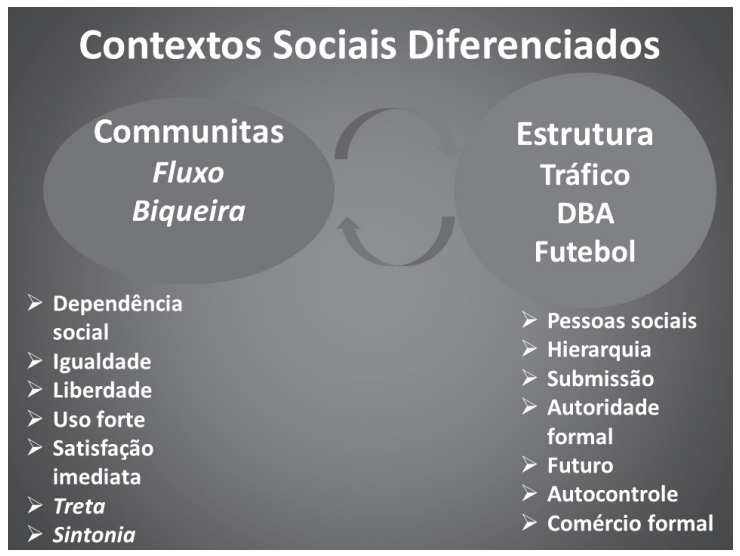

Fonte: Coleção particular do autor. 
Além de apontar a existência de controles informais sobre o uso do crack este livro procurou observar o que ocorria de fato, nas cenas de uso, sem preocupar-se em fazer um discurso antidrogas, ou em desencorajar seu uso. Se partíssemos do pressuposto do uso de substâncias tornadas ilícitas serem um mal absoluto a ser combatido de todas as maneiras, teriamos feito um estudo mais dedutivo que indutivo. Nada do exposto aqui foi elaborado sem ter saído da interlocução no campo. Distorcer os fatos observados e elaborados a partir do campo, em nome do apoio ao discurso de condenação ao uso de drogas ilícitas, nos colocaria sob o risco de ficarmos desmoralizados frente aos usuários e potenciais usuários quando percebessem nossa falsificação. Mais que isto, eles poderiam passar a desconfiar de qualquer discurso sobre as consequências danosas do uso do crack que por ventura pudéssemos vir a proferir. Certamente, o consumo do crack pode trazer danos terriveis, mas em certos contextos, seu uso pode ser diminuído e mesmo administrado de modo mais controlado e até ser uma maneira de se buscar uma certa vida comunitária. Estes dados deveriam ser levados em conta ao se elaborar estratégias para lidar com o uso compulsivo, mesmo se considerarmos que boa parte do dano causado pelo crack venha de seu status ilegal.

Consideramos que prevenir os danos e riscos mencionados acima, provenientes do uso "forte" de crack, será mais importante do que prevenir a experimentação da substância. Mas isso requer uma mudança das condições promotoras de modos deletérios de uso e passa pela manutenção das condições propícias à manutenção do controle, como faz o Programa DBA. Infelizmente, a mudança do uso de crack para o uso da maconha, por exemplo, uma droga pouco danosa à saúde física ou mental, não pode ser encorajada oficialmente por pairar ainda sobre a cannabis a espada do proibicionismo. Além disto, acreditamos que, no âmbito do Programa DBA e da oficina de futebol por nós pesquisados, os controles informais devem ser 
instituídos pelos próprios usuários. Assim, o que se pode fazer é fornecer ambientes mais propícios ao seu desenvolvimento.

Para se ter uma visão realista do uso do crack, deve-se considerar inclusive seus beneficios, como fizemos. Usar crack é importante para se manter acordado no ambiente hostil da rua e é uma maneira de construir amizades e de estar próximo a pessoas em situação similar. O crack faz as pessoas permanecerem juntas; reúne e une. Em seu entorno, uma série de atividades preenche uma rotina que, caso contrário, poderia ser marcada pelo mais profundo tédio e solidão. Portanto, concluímos que nem todo uso não prescrito medicamente de drogas, mesmo do crack nas ruas, deve ser visto como essencialmente destituído de um propósito válido. 


\section{REFEREENCIAS}

AGAR, M. Riping and running. New York: Academic Press, 1973.

AGAR, M. Getting better quality stuff: Methodological competition in an interdisciplinary niche. Journal of Contemporary Ethnography, v. 9, n. 1, p. 34-50, apr. 1980.

ALMEIDA, M. I.; EUGENIO, F. Paisagens existenciais e alquimias pragmáticas: uma reflexão comparativa do recurso às "drogas" no contexto da contracultura e nas cenas eletrônicas contemporâneas. In: LABATE, B. C. (Org.). Drogas e cultura: novas perspectivas. Salvador, BA: EDUFBA, 2008. p. 383-408.

ALVES, Y. D. Um vício deselegante: o preconceito racial e a transformação da maconha em problema público no Brasil. 1998. 136f. Dissertação (Mestrado) - Pontificia Universidade Católica de Sao Paulo, São Paulo, 1998.

ALVES, Y. D. Internação involuntária de usuários de crack. 2014. Disponivel em: <http://prezi.com/kku2kzve4i94/internacaoinvoluntaria-de-usuarios-de-crack/>. Acesso em: 6 maio, 2014.

ALVES, Y. D. Espiritualidade: grupos de ajuda mútua na contramão da conversão de usuários abusivos de drogas. In: SEMINÁRIO INTERNACIONAL DA PÓS-GRADUAÇÃO EM CIÊNCIAS SOCIAIS, 1., Uberlândia, 2012.

AQUINO, W. Verão da lata: um verão que ninguém esqueceu. Rio de Janeiro: Texto Editores, 2012.

ARAUJO, T. Almanaque das drogas: um guia informal para o debate racional. São Paulo: Leya, 2012.

ARISTÓTELES.Tópicos. Dos argumentos sofisticos. Metafisica Livro I e II. Ética a Nicômaco. Poetica. São Paulo: Abril cultural, 1973. (Os Pensadores).

ASSOCIAÇÃO INTERNACIONAL DE REDUÇÃO DE DANOS- IHRA. O que é Redução de Danos? Uma posição oficial da Associação Internacional de Redução de Danos. Londres, 2010. Disponível em: <http:/ /www.ihra.net/files/2010/06/01/Briefing_what_is_HR_ Portuguese.pdf>. Acesso em: 26 maio 2014. 
ATKINSON, P. Introduction: Ethnography as a method and as a genre. In: ATKINSON, P. The ethnographic imagination: textual construction of reality. London; New York: Routledge, 1990.

BACELAR, J. Gingas e nós: o jogo do lazer na Bahia. Salvador: Fundação Casa de Jorge Amado, 1991.

BASTOS, F.; BERTONI, N. Pesquisa nacional sobre o uso do crack: quem são os usuários de crack e/ou similares do Brasil? quantos são nas capitais brasileiras? Rio de Janeiro: ICICT; FIOCRUZ, 2014.

BECKER, H. History, culture and subjetive expirience: an exploration of the social bases of drug-induced experiences. Journal of Health and Social Behavior, v. 8, n. 3, p. 162-176, sep. 1967.

BECKER, H. Oral History Interviews with Substance Abuse Researchers. Substance Abuse Research Center, 2005. Disponivel em: <sitemaker.umich.edu/substance.abuse.history/oral_history_ interviews $\&$ mode $=$ single\&recordID $=2287158 \&$ nextMode $=$ list $>$. Acesso em: 24 nov. 2014.

BECKER, H. S. Outsiders: estudos de sociologia do desvio. Rio de janeiro: Jorge Zahar, 2008.

BERGAMIM JÚNIOR, G. Haddad diz que faltam policiais na cracolândia; PM nega redução. Folha de São Paulo, São Paulo, 20 nov. 2014. Disponivel em: <http://www1.folha.uol.com.br/ cotidiano/2014/11/1550822-haddad-diz-que-faltam-policiais-nacracolandia-pm-nega-reducao.shtml>. Acesso em: 25 nov. 2014.

BERGAMIN JUNIOR, G. Isolar dependente químico nem sempre ajuda, diz Prefeitura de São Paulo. Folha UOL, São Paulo. 21 out. 2010. Disponivel em: <http:/ /www1.folha.uol.com.br/ cotidiano/2013/10/1359667-isolar-dependente-quimico-nemsempre-ajuda-diz-prefeitura.shtml>. Acesso em: 14 maio 2014. BERNARD, H. R. Participant Observation. In: BERNARD, H. R. Research methods in anthropology: qualitative and quantitative approaches. 4. ed. New York: Altamira, 2008. p. 342-386.

BERREMAN, G. D. Behind many masks. [Ithaca, N. Y]: Society for Applied Anthropology, 1962. 
BOES, G. M. "Crack, nem pensar": um esboço sobre mídia e politica criminal. 2011. 181f. Dissertação (Mestrado) - Faculdade de Direito, Pontificia Universidade Católica, Porto Alegre, RS, 2011.

BOLAFFI, G. A saga da comida: receitas e história. 3. ed. São Paulo: Record, 2000.

BOSARI, J. R. Futebol de campo. São Paulo: EDU, 1989.

BOURDIEU, P. Esboço de uma teoria da prática. In: ORTIZ, R. A sociologia de Pierre Bourdieu. São Paulo: Olho d'água, 2003. p. 39-72.

BOURGOIS, P. In search of respect: selling crack in El Barrio. Nova Iorque: Cambridge University Press, 2006.

BOURGOIS, P.; SCHONBERG, J. Righteous dopefiends. Los Angeles: University of California Press, 2009.

BRASIL. Ministério da Saúde. Guia prático de matriciamento em saúde mental. Brasília, DF, 2011.

BUCHER, R. A função da droga no (dis)funcionamento social. In: BUCHER, R. Drogas e sociedade nos tempos da AIDS. Brasilia, DF: UNB, 1996. p. 46-62.

BUCHER, R.; OLIVEIRA, S. O discurso do "combate às drogas" e suas ideologias. Rev. Saúde Pública, v. 28, n. 2, p. 137-45. abr. 1994. BURROUGHS, W. Junky: drogado. São Paulo: Companhia da Letras, [2013].

CALLON, M. Entrevista com Michel Callon. Dos estudos de laboratório aos estudos de coletivos heterogêneos, passando pelos gerenciamentos econômicos. Sociologias. Porto Alegre, v. 10, n. 19, p. 302-321. jan./jun. 2008. Disponivel em: <http://www.redalyc. org/articulo.oa?id=86819552013>. Acesso em: 8 jan. 2014.

CAROSO, C. A imagem e a ética na encruzilhada das ciências. In: VÍCTORA, C. G. (Org.). Antropologia e ética: o debate atual no Brasil. Niterói, RJ: Editora da Universidade Federal Fluminense. 2004. p. $50-137$.

CARVALHO, V. A.; CARLINI-COTRIM, B. Atividades extracurriculares e prevenção ao abuso de drogas: uma questão polêmica. Rev. Saúde Pública. São Paulo, v. 26, n. 3, p. 145-149, jun. 1992. 
CASTRO, C. A. Arte de Fumar Cachimbo. Confraria dos Amigos do Cachimbo. Disponível em: <http://www.amigosdocachimbo.com.br/ artigos/art_cachimbo_fumar.htm>. Acesso em: 10 ago. 2013.

CAVALCANTE, D. F. Faces do futebol-arte no Brasil: da sedução malandra à imaginação. Fortaleza: Expressão Gráfica, 2011.

CILLO, N. Projeto social usa futebol para combater as drogas. Uol Mais. São Paulo, 19 jun. 2014. Disponivel em: <http://mais.uol.com. $\mathrm{br} /$ view/cphaa0gl2x8r/projeto-social-usa-futebol-para-combateras-drogas-04028C9B3362CCC14326?types $=\mathrm{V}>$. Acesso em: 11 jun. 2014.

CLEGG, B. Retrato de um viciado quando jovem. São Paulo: Companhia das Letras, 2010.

COMPLEXO PRATES. Centro de convivência especial. São Paulo, 2014. Disponivel em: <http://complexoprates.blogspot.com.br/p/ centro-de-convivencia-especial.html>. Acesso em: 5 nov.2014.

COSTA, C. E. Torneios universitários: disputas e sociabilidade nas práticas desportivas estudantis. In: TOLEDO, L. H.; COSTA, C. E. (Org.). Visão de jogo: antropologia das práticas desportivas: Terceiro Nome, 2009. p. 279.

COSTA, P. Metodologia do jogo. s.d. Disponivel em: <http:// pedrocostafutsal.tripod.com/futsal/id27.html>. Acesso em: 25 jun. 2014.

DAMATTA, R. Um ensaio sobre o futebol brasileiro. In: DAMATTA, R. Universo do futebol: esporte e sociedade brasileira. Rio de Janeiro: Pinakotheke, 1982. p. 124.

DAMATTA, R. Antropologia do óbvio: um ensaio em torno do significado social do futebol brasileiro. In: DAMATTA, R. A bola corre mais que os homens: duas copas, treze crônicas e três ensaios sobre futebol. Rio de janeiro: Rocco, 2006. p. 201.

DELEUZE, G.; GUATTARI, F. A thousand plateau. London: Continuum, 2004.

DOMANICO, A. "Craqueiros e Cracados: bem vindo ao mundo dos nóias!" estudo sobre a implementação de estratégias de redução de danos para usuários de crack nos cinco projetos-piloto do Brasil. 
2006. 220f. Tese (Doutorado) - Universidade Federal da Bahia, Faculdade de filosofia e Ciências Humanas, Salvador, 2006.

DURKHEIM, É. Objetividade e identidade na análise da vida social. In: FORACCHI, M. M.; MARTINS, J. S. Sociologia e sociedade: leituras de introdução à sociologia. Rio de Janeiro: LTC, 1995. p. 23-52.

ENGLUND, H.; LEACH, J. Ethnography and the Meta Narratives of Modernity. Current Anthropology, Chicago, EUA, v. 41, n. 2, p. 225-248, apr. 2000.

ELIAS, N. A sociedade dos individuos. Rio de Janeiro: Zahar, 1994.

ELIAS, N. A sociedade de corte: investigação sobre a sociologia da realeza e da aristocracia da corte. Rio de Janeiro: Zahar, 2001.

ELIAS, N.; KAMNITZER, P. La dynamique de l'Occident. Paris: pocket, 2007.

FAVRET-SAAD. J. "Ser Afetado". Cadernos de campo, n. 13, p. 155-161, 2005.

FELSCHERINOW, C.; VUKOVIC, S. Eu, Christiane F., a vida apesar de tudo. 2. ed. Rio de Janeiro: Bertrand Brasil, 2014.

FERNANDES, L.; PINTO, M. El espacio urbano como dispositivo de control social: territorios psicotrópicos y políticas de la ciudad. In: ORIOL, R. A. (Ed.). Uso de drogas y drogodependencias. Barcelona: Fundación Medicina y Humanidades, 2004. p. 147-162.

FERNANDEZ, O. Redes juvenis, droga injetável e o HIV/AIDS. Revista USP. São Paulo, v. 33, p. 102-115, mar./maio. 1997.

FERNANDEZ, O. Coca light?: usos do corpo, rituais de consumo e carreiras de "cheiradores" de cocaína em São Paulo. 2007. 327f. Tese (Doutorado) - Universidade Fedreal da Bahia, Faculdade de Filosofia e Ciência Humanas, Salvador, 2007.

FIDALGO, T. M.; NETO, P. M.; SILVEIRA, D. X. Abordagem da dependência química. In: UNIVERSIDADE FEDERAL DE SÃO PAULO. Especilização em saúde da família Mosalidade a distância: módulos de casos complexo 12 vila Santo Antonio. São Paulo, 1933. p. 14-17. Disponivel em: <http://www.unasus.unifesp.br/biblioteca virtual/esf/1/casos_complexos/Vila_Santo_Antonio/Complexo_12_ Vila_Abordagem_dependencia.pdf>. Acesso em: 23 abr. 2014. 
FIORE, M. Uso de drogas: substâncias, sujeitos e eventos. 2013. 209f. Tese (Doutorado) - Universidade Estadual de Campinas, Instituto de Filosofia e Ciências Humanas, Campinas, SP, 2013.

FOUCAULT, M. Vigiar a punir: história da violência nas prisões. Petrópolis, RJ: Vozes, 1997.

FOUCAULT, M. Em defesa da sociedade: curso no collége de France. São Paulo: Martins, 1999.

GALEANO, E. Futebol ao sol e à sombra. Porto Alegre: L\&PM, 1995.

GALLIHER, J. Social Scientists' Ethical Responsabilities to Superordinates: Looking Upward Meekly. In: EMERSON, R. M. Contemporary Field Research: a collection of readings. Boston; Toronto: Little Brown and Company. 1983. p. 300-311.

GEERTZ, C. Um jogo absorvente: notas sobre a briga de galos balinesa. In: GEERTZ, C. A interpretação das culturas. Rio de Janeiro: Guanabara Koogan, 1989. p. 278-321.

GOFFMAN, E. Estigma: notas sobre a manipulação da identidade deteriorada. Rio de Janeiro: Zahar, 1975. (Coleção Biblioteca de Antropologia Social).

GOFFMAN, E.; MCGINNIS, R. Encounters: two studies in the sociology of interaction. Indianápolis: The Bobbs-Merrill, [1961].

GOMART, E. Methadona: six effects in search of a substance. Social Studies of Science. London. v. 32, n. 1, p. 93-135, feb. 2002.

GOMES, B. R.; ADORNO, R. C. F. Tornar-se "noia": trajetória e sofrimento social nos "usos de crack" no centro de São Paulo. Etnográfica, v. 15, n. 3, p. 569-586, out. 2011.

GREGIS, C. Fissura da rua: corpo e ritual de uso de droga injetável entre meninos de rua. 2002. 77f. Dissertação (Mestrado) - Instituto de Filosofia e Ciências Humanas, Universidade Federal do Rio Grande do Sul, Porto Alegre, 2002.

GRUND, J.-P. C. Drug use as a social Ritual: functionality, symbolism and determinants of self-regulation. Dissertation (Masters) Institute Voor Verslavingsondersoek, Erasmus Universiteit, Rotterdam, 1993. Disponivel em: <https://www.researchgate.net/ publication/280318868_Drug_Use_as_a_Social_Ritual_Functionality_ Symbolism_and_Determinants_of_Self_Regulation>. Acesso em: ? 
HABERMAS, J. Mudança estrutural da esfera pública: investigações quanto a uma categoria da sociedade burguesa. Rio de Janeiro: Tempo Brasileiro, 2003. (Biblioteca Tempo Universitário). HERZFELD, M. Cultural Intimacy: social poetics in the Nation-State. New York: Routledge, 1997.

HUIZINGA, J. Homo Ludens:o jogo como elemento da cultura. São Paulo: Perspectiva, 1996.

INGOLD, T. Trazendo as coisas de volta à vida: emaranhados criativos num mundo de materiais. Horizontes Antropológicos, Porto Alegre, v. 18, n. 37, p. 25-44, jan./jun. 2012.

JOANIDES, H. M. Boca do Lixo. 5. ed. [São Paulo]: Populares, 1978. JOHNSON, J. Trust and Personal Involvements in Fieldwork. In: EMERSON, R. M. Contemporary Field Research: a collection of readings. Boston; Toronto: Little Brown and Company. 1983. p. 203215 .

KAY, J.; TASMAN, A.; LIEBERMAN, J. A. Psiquiatria: ciência comportamental e fundamentos clínicos. Barueri: Manole, 2002. KOTLER, P.; KELLER, K. Administração de marketing. São Paulo: Pearson Prentice Hall, 2006.

KWITKO, M. Cannabis Sativa (maconha). Clube Stum. 4 nov. 2010. Disponivel em: <http://somostodosum.ig.com.br/clube/artigos. asp?id=24045>. Acesso em: 17 dez. 2014.

LARANJEIRA, R. Especialistas discutem o vício em crack. Globo.com. Rio de janeiro, 26 out. 2009. Disponivel em: <http://jornalnacional. globo.com/Telejornais/JN/0,,MUL1355694-10406,00-ESPECIALIS TAS+DISCUTEM+O+VICIO+EM+CRACK.html>. Acesso em: 7 maio 2014.

LATOUR, B. Jamais fomos modernos. São Paulo: Ed. 34, 1994.

LATOUR, B. Ciência em ação: como seguir cientistas e engenheiros sociedade afora. São Paulo: UNESP, 2000.

LATOUR, B. A esperança de Pandora: ensaios sobre a realidade dos estudos científicos. São Paulo: EDUSC, 2001. (Filosofia e Política). 
LATOUR, B. Como falar do corpo? A dimensão normativa dos estudos sobre ciência. In: NUNES, J. A.; ROQUE, R. (Org.). Objetos impuros: experiências em estudos sobre a ciência. Porto: Afrontamento, 2008.

LATOUR, B. Reagregando o social: uma introdução à teoria do atorrede. Salvador: EDUFBA; Bauru, SP: EDUSC, 2012.

LAW, J. Notes on the Theory of Actor-Network: Ordering, Strategy and Hetergeneity. Systems Practice, v. 5, n. 4, p. 379-393, aug. 1992. Disponivel em: <http://www.lancaster.ac.uk/fass/resources/ sociology-online-papers / papers/law-notes-on-ant.pdf>. Acesso em: 7 maio 2014.

LEARY, T. Flashbacks "surfando no caos": a história pessoal e cultural de uma era uma autobiografia. São Paulo: Beca, 1999.

LOBÃO. Canos Silenciosos. São paulo: DeckDisk, 2011. 1CD.

LOSCHIAVO, M. C. Arquitetura, os moradores de rua e a transfiguração de nossa sociedade. [S.1.]: Arqtexto 7, 2005.

MACEDO, L. Favela na cracolândia será retirada nesta semana, diz prefeitura de SP. G1. São Paulo, 13 jan. 2014. Disponível em: <http://g1.globo.com/sao-paulo/noticia/2014/01/favela-nacracolandia-sera-retirada-nesta-semana-diz-prefeitura-de-sp.html>. Acesso em: 26 maio 2014.

MACHADO, R. Danação da Norma: medicina social e constituição da psiquiatria no Brasil. Rio de Janeiro: Graal, 1978.

MACRAE, E. Abordagens qualitativas na compreensão do uso de psicoativos. In: ALMEIDA, A. R. et al. (Org.). Drogas: tempos, lugares e olhares sobre seu consumo. Salvador: EDUFBA; CEETAD, 2004. p. 27-48.

MACRAE, E. Prefácio. In: MACRAE, E.; TAVARES, L. R.; NUÑES, M. E. (Org.). Crack: contextos, padrões e propósitos de uso. Salvador: EDUFBA, 2013. p. 11-27. (Drogas: clinica e cultura).

MACRAE, E.; SIMÕES, J. A. Rodas de fumo: o uso da maconha entre camadas médias urbanas. Salvador: EDUFBA, 2000. (Drogas: clinica e cultura).

MACRAE, E.; VIDAL, S. A Resolução 196/96 e a imposição do modelo biomédico na pesquisa social: Dilemas éticos e metodológicos do antropólogo pesquisando o uso de substâncias psicoativas. 
Revista de Antropologia, São Paulo, v. 49, n. 2, p. 646-666, jul./dez. 2006.

MALHEIROS, L. Tornando-se um usuário de crack. In: NERY FILHO, A. et al. As drogas na contemporaneidade: perspectivas clínicas e culturais. Salvador: EDUFBA, 2012. p. 79-100.

MALHEIROS, L. S. "Entre sacizeiro, usuário e patrão": Um estudo etnográfico sobre consumidores de crack no Centro Histórico de Salvador. In: MACRAE, E.; TAVARES, L. R.; NUÑES, M. E. Crack: contextos, padrões e propósitos de uso. Salvador: EDUFBA. 2013. p. 154-227. (Drogas: clinica e cultura).

MALINOWSKI, B. Argonautas do pacífico ocidental: um relato do empreendimento e da aventura dos nativos nos arquipélagos da Nova Guiné Melanésia. 2. ed. São Paulo: Abril Cultural, 1978. (Os pensadores).

MAUSS, M. Efeito físico no indivíduo da ideia de morte sugerida pela coletividade. In: MAUSS, M. Sociologia e antropologia. São Paulo: EDUSP, 1974. p. 331.

MEDEIROS, R. Clínica e croni(cidade): impactos do uso/abuso de crack na configuração urbana e nos tratamentos da toxicomania. In: SAPORI, L. F.; MEDEIROS, R. Crack: um desafio social. Belo horizonte: PUC Minas, 2010. p. 220.

MONTEIRO NETO, A.; LEITE, M. M. Capacidade do jogo e consciência tática:como desenvolver? Jal. 3 jun. 2010. Disponivel em: <http://joseaugustolealfutsal.blogspot.com.br/2010/06/artigocapacidade-do-jogo-e-consciencia.html>. Acesso em: 14 fev. 2014.

MUNIZ, D. Centro para viviados em crack será aberto sem atendimento de saúde. TV Folha, São Paulo, 11 jan. 2012. Disponivel em: <http://www1.folha.uol.com.br/multimidia/ videocasts /2012/01/1032745-centro-para-viciados-em-crack-seraaberto-sem-atendimento-de-saude.shtml>. Acesso em: 26 maio 2014.

NAPPO, S. A. Comportamento de risco de mulheres usuárias de crack em relação às DST/Aids. São Paulo: Cebrid, [200-].

NAPPO, S. A.; SANCHEZ, Z. M.; RIBEIRO, L. A. Is there a crack epidemic among students in Brazil?: comments on media and public health issues. Cad. Saúde Pública. Rio de janeiro, v. 28, n. 9, p. 1643-1649, set. 2012. 
NASSIF, M. I. Crack é usado por miseráveis porque é barato. Carta Maior, São Paulo, 17 jan. 2012. Disponivel em: <http:// www.cartamaior.com.br/?/Editoria/Politica/Crack-e-usado-pormiseraveis-porque-e-barato\%0D\%0A/4/18370>. Acesso em: 26 maio 2014.

NERY FILHO, A. Governo erra ao focar o crack, diz médico. Folha de São Paulo, São Paulo, 11 dez. 2011. Disponível em: <http://www1. folha.uol.com.br/fsp/cotidian/14281-governo-erra-ao-focar-o-crackdiz-medico.shtml>. Acesso em: 23 maio 2014.

NERY FILHO, A.; VALÉRIO, A. L.; MONTEIRO, L. F. Guia do projeto consultório de rua. Salvador: SENAD; CETAD, 2011.

NEWMAN, A. K. A study of the causes leading to the extinction of the Maori. Trans. N. -Zel. Inst., v. 14, p. 459-477, 1881. Disponivel em: <http://rsnz.natlib.govt.nz/volume/rsnz_14/rsnz_14_00_006550. pdf>. Acesso em: 7 maio 2014.

NOBRE, E. A. Intervenções urbanas em Salvador: turismo e 'gentrificação' no processo de renovação urbana do Pelourinho. In: ENCONTRO NACIONAL DA ANPUR, Anais... Belo horizonte, 2003.

NOTÍCIAS DE ITABUNA. Crack ascende nas camadas sociais. Notícias de Itabuna, Itabuna, BA, 7 mar. 2012. Disponivel em: <http://noticiasdeitabuna.blogspot.com.br/2012/03/crack-ascendenas-camadas-sociais.html>. Acesso em: 7 abr. 2014.

NOTO, A. R. et al. Cobertura jornalística sobre drogas: distorções e potencialidades. In: RONZANI, T. M. Ações integradas sobre drogas: prevenção, abordagens e politicas públicas. Juiz de Fora, MG: UFJF, 2013. p. 448.

OLIVEIRA, L. G. Avaliação da cultura do uso de crack após uma década da introdução da droga na cidade de São Paulo. 2007. 330f. Tese (Doutorado) - Programa de Pós-Graduação em Psicobiologia, Universidade Federal de São Paulo, São Paulo, 2007.

OLIVEIRA, L. R. Antropologia e Pesquisa em versus pesquisa com seres humanos. In: OLIVEIRA, L. R. (Org.). Antropologia e ética: o debate atual no Brasil. Niterói, RJ: EDUFF, 2004. p. 33-44.

ORTIZ, E. Por que não dancei. 3. ed. São Paulo: SENAC, 2001. 
PADILHA, A. Roda Viva. São Paulo, 2014. Disponível em: <https:// www.youtube.com/watch?v=ck0Rd0Yv9Hk>. Acesso em: 23 jun. 2014.

PIERRO, B. A saúde mental em São Bernardo do Campo. Brasilianas. org. São Paulo, 2 fev. 2012. Disponivel em: <http://advivo.com. $\mathrm{br} / \mathrm{materia-artigo/especial-caps-parte-iv-a-saude-mental-em-sao-}$ bernardo-do-campo>. Acesso em: 16 abr. 2014.

PREFEITURA DE SÃO PAULO. Secretaria Executiva de Comunicação. Mães que moram em hotéis da Nova Luz temem exposição de filhos. São Paulo, 2014a. Disponivel em: <http://www.capital.sp. gov.br/ portal/noticia/3658/>. Acesso em: 18 set. 2014.

PREFEITURA DE SÃO PAULO. Secretaria Executiva de Comunicação. Criminalidade cai na cracolândia após ações do programa De Braços Abertos. São Paulo, 2014b. Disponível em: <http://www.capital. sp.gov.br/portal/noticia/3592>. Acesso em: 18 set. 2014.

PREFEITURA DE SÃO PAULO. Secretaria Municipal da Saúde. Relatórios Consolidados das Pré-Conferências. 2013. Disponivel em: <http://www.prefeitura.sp. gov.br/cidade/secretarias/ upload/Pasta\%20PDF\%20Portal\%20R/RelatoriosConsolidados_ PreConferencias_2013.pdf>. Acesso em: 16 abr. 2014.

PREFEITURA DE SÃO PAULO. Secretaria Municipal de Assistência e Desenvolvimento Social. Plano de assistência social do municipio de São Paulo. São Paulo, 2010.

PREFEITURA DE SÃO PAULO. Assessoria Especial de Políticas Públicas Sobre Drogas. Propostas para o V Compad. São Paulo, 22 de out. 2013. Disponivel em: <http://www.prefeitura.sp. gov. br/cidade/secretarias/direitos_humanos/politica_sobre_drogas / noticias/?p=159635>. Acesso em: 16 abr. 2014.

PREFEITURA DE SÃO PAULO. Projeto Nova Luz. São Paulo, 2011. Disponivel em: <http://www.prefeitura.sp. gov.br/cidade/ secretarias/upload/desenvolvimento_urbano/arquivos/nova_ luz/201108_PUE.pdf>. Acesso em: 14 maio 2014.

PREFEITURA DE SÃO PAULO. Secretaria Municipal de Direitos Humanos e Cidadania. Ata da VI reunião ordinária do comitê intersetorial da política municipal da população em situação de rua. São Paulo, 2013. Disponivel em: <http://www.prefeitura.sp.gov.br/ 
cidade/secretarias/upload/direitos_humanos/Ata\%20da\%20VI\%20 Reuniao\%200rdinaria\%20Comite\%20\%2002_10_2013.pdf>. Acesso em: 16 abr. 2014.

RADCLIFFE-BROWN, A. R. The Andaman Islanders. [S.1.]: Free Press, 1922.

RAUPP, L.; ADORNO, R. C. F. Circuitos de uso de crack na região central da cidade de São Paulo. Ciência \& Saúde Coletiva, São Paulo, v. 16, n. 5, p. 2613-2622, 2011.

RODRIGUES, N. A pátria em chuteiras: novas crônicas de futebol. São Paulo: Companhia das Letras, 1994.

RUI, T. C. Corpos Abjetos: etnografia em cenários de uso e comércio de crack. 2012. 335f. Tese (Doutorado) - Programa de Pós-Graduação em Antropologia Social, Universidade Estadual de Campinas, Campinas, SP, 2012.

SANTOS, F. C. Rodas de fumo no Centro Histórico de Salvador, Bahia. In: CONGRESSO BRASILEIRO DE SOCIOLOGIA, 16., Anais... Salvador, 2013.

SÃO PAULO. Portaria 46/2010. Dispõe sobre a tipificação da rede socioassistencial do municipio de são paulo e a regulação de parceria operada por meio de convênios. Disponivel em: <http://www. prefeitura.sp.gov.br/cidade/secretarias/upload/assistencia_social/ arquivos/portarias/portaria_46-2010.pdf>. Acesso em: 3 mar. 2014.

SENNET, R. O declínio do homem público. As tiranias da intimidade. São Paulo: Companhia das Letras, 1988.

SENNETT, R. O artifice. 3. ed. Rio de Janeiro: Record, 2012.

SENNETT, R. Juntos: os rituais, os prazeres e a política da cooperação. Rio de Janeiro: Record, 2012.

SILVA, C. G. Manejo em situações de crise. In: RIBEIRO, M.; LARANJEIRA, R. (Org.). O tratamento do usuário de crack. 2. ed. Porto Alegre: Artmed, 2012.

SILVA, S. L. Mulheres da Luz: uma etnografia dos usos e preservação no uso do "Crack". 2000. 98f. Dissertação (Mestrado em Serviços de Saúde Pública) - Faculdade de Saúde Pública, Universidade de São Paulo, São Paulo, 2000. 
SILVEIRA, D. X. et al. Is Drug Use Related to the Choice of Potentially More Harmful Methods in Suicide Attempts? Substance Abuse: Research and Treatment, v. 8, p. 41-43. may. 2014. Disponivel em: <http://www.ncbi.nlm.nih.gov/pubmed/24932103>. Acesso em: 23 abr. 2014.

SIMMEL, G. The sociology of Georg Simmel. Glencoe, Illinois: The Free Press, [1950].

STRATHERN, M. "The Limits of AutoAnthropology". In: JACKSON, A. (Ed.). Anthropology at Home. London, NY: Tavistock Publications, 1987.

STRATHERN, M. The Gender of the Gift: Problems with Women and Problems with Society in Melanesia. Berkeley, CA: University of California Press, 1988.

STRATHERN, M. Property Substance and Effect: anthropological essays on persons and things. London; New Brunswick, NJ: Athlone Press, 1999.

TURNBULL, C. Sex and gender: The role of subjectivity in field research. In: WHITEHEAD, T. L.; CONOWAY, M. E. Self, sex and gender in cross-cultural fieldwork. University of Illinois Press, 1986. p. 17-29.

TURNER, V. O processo ritual: estrutura e antiestrutura. Petrópolis, RJ: Vozes, 1974.

(UM)TEMPO novo para São Paulo. Plano de governo. São Paulo, 2012.

VAN MAANEN, J. The Moral Fix: On the Ethics of Fieldwork. In: EMERSON, R. M. Contemporary Field research: a collection of readings. [Boston]: Little, Brown and Cop., 1983. p. 269-287.

VARGAS, E. V. Uso de drogas: uma alter-ação como evento. Rev. Antropol. São Paulo, v. 49, n. 2, p. 582-623, jul./dez. 2006.

VELHO, G. Becker, Goffman e a antropologia no Brasil. Sociologia, problemas e práticas, n. 38, p. 9-17, maio, 2002.

VELHO, G. O estudo do comportamento desviante: a contribuição da antropologia social. In: VELHO, G. Um antropólogo na cidade: ensaios de antropologia urbana. Rio de Janeiro: Zahar, 2013. p. 36-51. (Antropologia Social). 
VIDAL, B. Política fracassada, criminalização do usuário ainda pauta combate ao crack no país. Carta Maior, São Paulo, 1 fev. 2013. Disponivel em: <http://www.cartamaior.com.br/?/Editoria/ Direitos-Humanos/Politica-fracassada-criminalizacao-do-usuarioainda-pauta-combate-ao-crack-no-pais/5/27342>. Acesso em: 18 jun. 2014.

VIEIRA, R. A. As injunções da pedra. In: SAPORI, L. F.; MEDEIROS, R. (Org.). Crack: um desafio social: PUC Minas. 2010. p. 102-124.

VILLELA, J. L. Por uma etnografia da pelada: descrição de um caso. In: MURAD, M. et al. Pesquisa de campo: futebol e cidadania. Rio de Janeiro: UERJ, 1997. p. 69-95.

VIVA SEM DROGAS. Fique sabendo. Viva sem drogas. 2014.

Disponivel em: <http://vivasemdrogas.com.br/fique-sabendo/crack. html>. Acesso em: 14 ago. 2014.

VIVEIROS DE CASTRO, E. O Nativo Relativo. Mana, Rio de janeiro, v. 8, n. 1, p. 113-148, abr. 2002.

WAGNER, R. The Invention of Culture. Chicago, EUA: University of Chicago, 1981.

WEBER, M.; GERTH, H.; MILLS, C. W. From Max Weber: essays in sociology. New York: Oxford university Press, 1946.

WHYTE, W. F. Sociedade de esquina: a estrutura social de uma área urbana pobre e degradada. Rio de janeiro: Zahar, 2005.

ZINBERG, N. E. Drug, Set, and Setting: the basis for controlled intoxicant use. New Haven, EUA: Yale University, 1984. 


\section{GLOSSÁRIO}

Acolhido - termo técnico utilizado pelos orientadores socioeducativos e demais profissionais dos equipamentos destinados a abrigar a população em situação de rua para referir-se a esta população quando atendida. Para aqueles usuários apenas dos serviços da Tenda, o termo utilizado é convivente.

Alumínio - trata-se de uma base perfurada sobre a qual é colocada a cinza e o "trago" em um cachimbo.

Aproximação - a expressão "gerar aproximação" designa atrair a atenção sobre um grupo de usuários.

Arrastar - induzir alguém a colocar-se numa situação desvantajosa ou perigosa.

Bic - isqueiro de qualquer marca.

Biqueira - local de comércio e por vezes de consumo de crack.

Bloco - pedra de crack comerciável.

Boris - cachimbo para consumo de crack.

Brisa - conjunto de sensações de certa forma idiossincráticas experimentadas a partir do uso do crack. Pode também dizer respeito ao comportamento de quem fumou.

Caminhada - a expressão "passar a caminhada" designa dar um conjunto de instruções, já a expressão "minha caminhada" trata-se da história de vida do usuário e a expressão "sair numa caminhada" significa percorrer certa distância, geralmente a pé.

Caninho - cilindro metálico vazado qualquer utilizado nos cachimbos de crack.

Chimbó - cachimbo para consumo de crack.

Cigarreiro - pessoa dedicada à venda de cigarros nas cenas de uso. 
Jamais fomos zumbis

Contenção - pessoa responsável pela segurança em uma "biqueira". Pode ser também o usuário indicado para garantir as boas condições ambientais e de insumos a uma roda de crack.

Convivente - frequentador(a) das tendas.

Corote - popular marca de aguardente.

Corre - o termo "corre" geralmente designa o movimento do usuário de crack em busca de fundos, ou seja, "Fazer um corre".

Curvinha - tipo de "fogãozinho" curvado em um ângulo de $90^{\circ}$.

Dragão - designa o usuário, geralmente inexperiente, que faz uso de grandes quantidades de crack com perda de droga.

Disciplina - pessoa ligada ao Primeiro Comando da Capital (PCC) responsável por manter a ordem em locais de venda e também naqueles dedicados ao uso concomitante a venda.

Espaço - local de comércio ligado a determinada "biqueira".

Favorecer - o termo "favorecer" no contexto desta frase é o ato de fornecer crack a alguém, porém, com um comprometimento em termos de gravidade da situação e divida adquirida menor que "fortalecer" alguém.

Fluxo - uma aglomeração humana com dezenas ou mesmo centenas de usuários de crack a depender de diversos fatores, desde climáticos, passando pela repressão policial ao tráfico, até a proximidade ou não dos dias de pagamento. A disponibilidade da droga também é fator importante na construção e localização do "fluxo". Ele está onde há droga e vice-versa, o crack é levado para próximo aos usuários e estes, por sua vez, se dirigem para o local com maior disponibilidade de crack. Aparentemente, próximo ao "fluxo", ou melhor, dentro dele, os "blocos" são mais "bem fechados", termo utilizado para se referir as pedras maiores e com embalagens ainda não violadas. Longe do "fluxo" as pedras disponíveis podem ser frações do "bloco original", sem necessariamente ter um preço menor. Dentro e fora dele, pode-se adquirir qualquer fração do 
"bloco" até chegar a doses unitárias, ou seja, suficiente para um "trago". Estas frações da pedra original de crack são trocadas também os mais diversos bens e serviços - dentro do "circuito da treta", tornando o fluxo um local de imensa agitação e até abrindo espaço aos "profissionais da treta", ou indivíduos dedicados a comprar e vender objetos usados e novos.

Fogãozinho - leva este nome por ser comumente uma peça de fogão. É o local sobre o qual ocorre a queima da pedra de crack. Dentro dele se acumula "rapa". Quando feito de cobre produz uma"rapa" branca, muito apreciada.

Fortalecer - prestar um grande favor a alguém.

Frango - usuário inexperiente.

Furador - pequena haste pontuda de metal utilizada para perfurar o alumínio.

Giz - pasta base de cocaína.

Maquinário - o mesmo que parafernália de uso.

Manguear - pedir esmolas.

Meter o louco - abusar da confiança. Levar vantagem indevida. Ludibriar.

Pacote - é o equivalente a uma certa quantidade de pedras de crack para venda. Dimensionado para expor o "vapor" a um risco aceitável de ser considerado traficante caso preso. Parte do pacote corresponde ao lucro do "vapor", na proporção de quatro pedras para cada pacote de 14 , por exemplo.

Parasita - pessoa que não faz seu "corre" e usa crack a expensas de outros usuários.

Paulada - "dar uma paulada" é equivalente a fumar crack.

Parça - colega. 
Radiação - barulho, confusão e desavenças trazidas para o ambiente onde se está consumindo crack.

Rapa - material proveniente da sublimação da fumaça de crack em contato com o interior do cachimbo. Podendo ser da coloração preta ou branca, mais apreciada.

Raspador - haste contundente de metal utilizada para retirar a "rapa" acumulada nas paredes do "fogãozinho" e mesmo no interior do "caninho".

Resumo - balanço das vendas em uma "biqueira". A expressão "Passar o resumo" significa fornecer uma série de informações sobre determinado assunto.

Segurar o flagrante - manter-se na posse, ou assumir possuir certa quantidade de crack em uma situação de contato com a polícia.

Sintonia - uma boa relação, uma espécie de harmonia nas atitudes. A "sintonia" é também efeito da droga. A pedra só abre o caminho, percorrê-lo na companhia de um "parça", ou mesmo com um desconhecido recém-chegado à "biqueira" é uma possibilidade aberta pelo uso. Estarem todos em "sintonia" é um prazer em si mesmo e, porque não, o principal prazer possibilitado pela pedra.

Trago - o trago é a unidade de consumo do "bloco". Pode significar tanto a quantidade colocada sobre o cachimbo, ou "boris", quanto o ato de fumar. Alguém, ao "favorecer" outro, pode referir-se ao pedaço do "bloco" ofertado como "trago", "está aí seu trago" e quem recebeu o pedaço da pedra, ao fumar, pode observar: "agora, vou dar meu trago". "Dar um bom trago" pode ser considerado o objetivo final do usuário e para tanto há de contribuir uma série de fatores.

Treta - troca generalizada de pedras de crack e outros bens. Por vezes, serviços também podem entrar no circuito da "treta".

Usuário(a) forte - quem consome grandes quantidades de crack.

Vapor - pequeno traficante, por vezes, também usuário. 


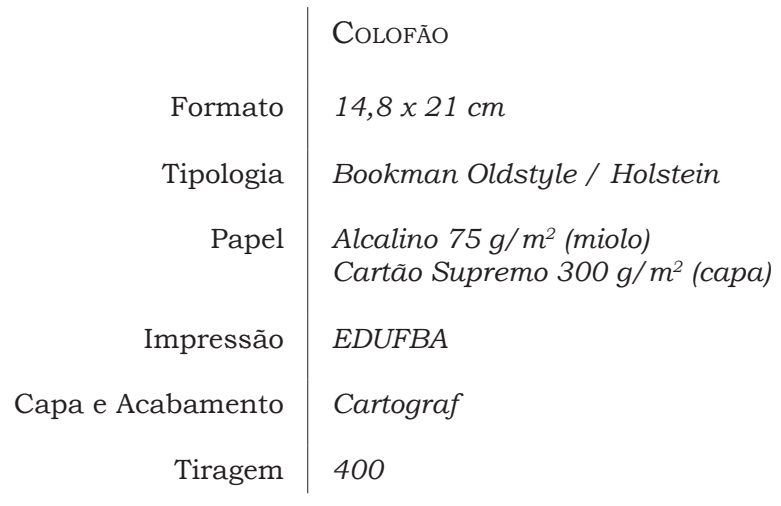

